Doktori (Ph.D.) értekezés

\title{
Hursán Dorottya
}

\section{SZÉN-DIOXID ELEKTROKÉMIAI REDUKCIÓJA NITROGÉNNEL ADALÉKOLT SZÉN ELEKTRÓDOKON}

\author{
TÉMAVEZETŐ:
}

Dr. Janáky Csaba

egyetemi docens

Kémia Doktori Iskola

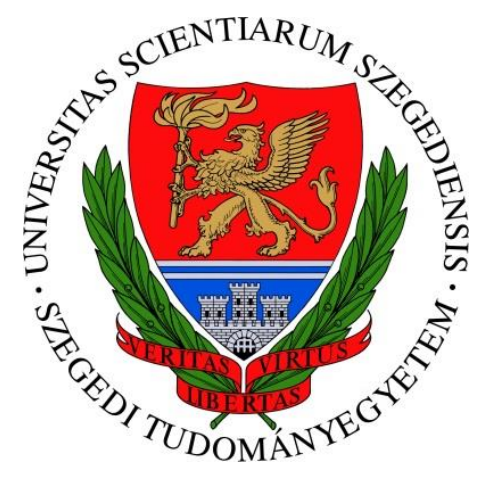

Szegedi Tudományegyetem

Természettudományi és Informatikai Kar

Fizikai Kémiai és Anyagtudományi Tanszék

Szeged, 2019 


\section{Tartalomjegyzék}

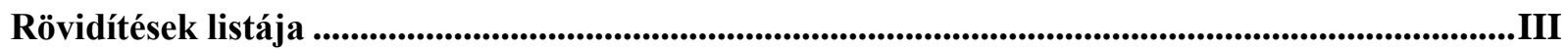

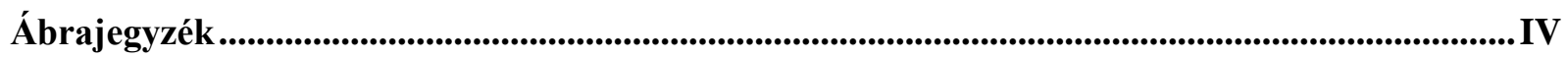

Táblázatok jegyzéke.................................................................................................................................................... VII

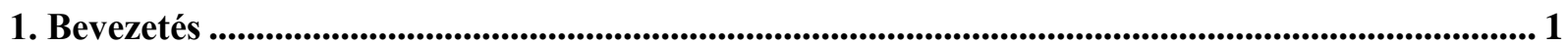

2. Irodalmi áttekintés ......................................................................................................................................... 3

2.1. Az elektrokémiai szén-dioxid redukció............................................................................................. 3

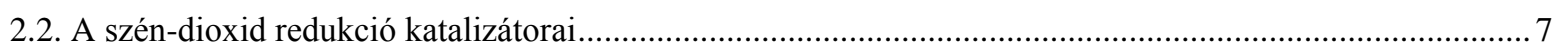

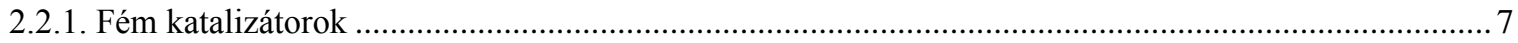

2.2.2. Nitrogénnel adalékolt szén katalizátorok ................................................................................. 9

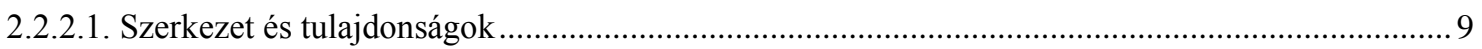

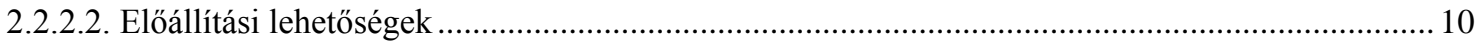

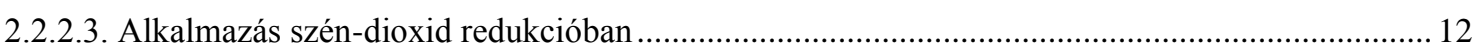

2.2.2.4. Aktív centrumok a szén-dioxid redukcióban .......................................................................... 14

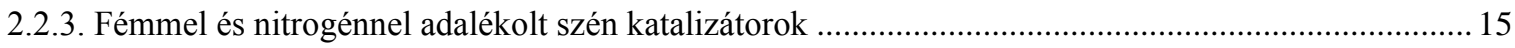

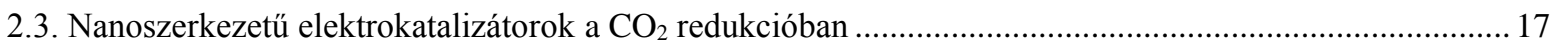

2.3.1. Morfológiai tényezők hatása a $\mathrm{CO}_{2}$ redukcióban............................................................................ 18

2.3.2. Nitrogénnel adalékolt szén elektródok morfológiájának szerepe elektrokémiai redukciós

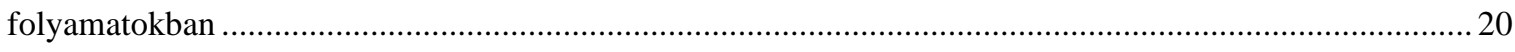

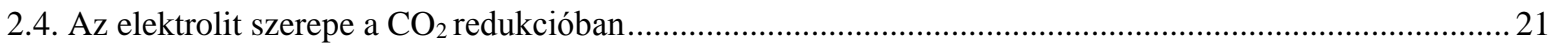

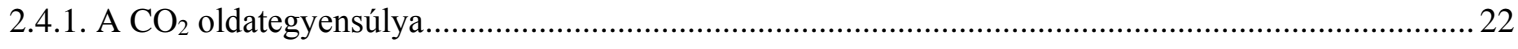

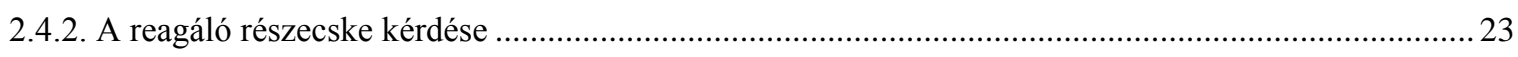

3. Motiváció és célkitüzések......................................................................................................................25

4. Felhasznált vegyszerek és alkalmazott kísérleti módszerek ............................................................. 27

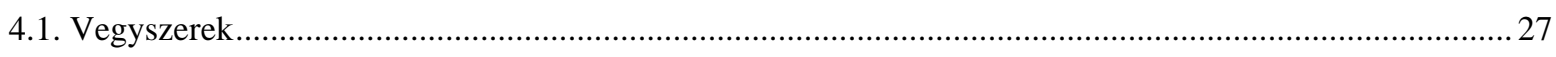

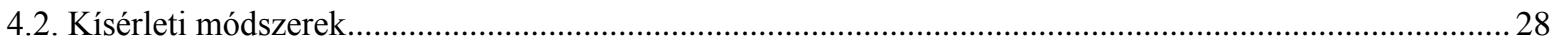

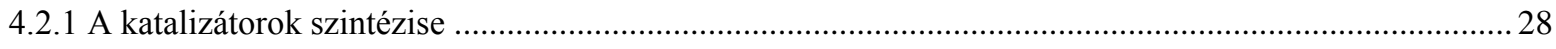

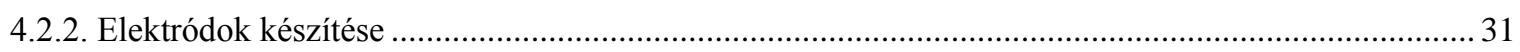

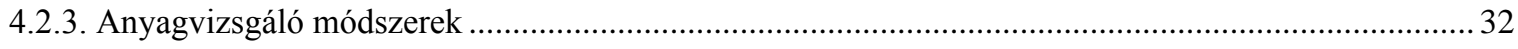

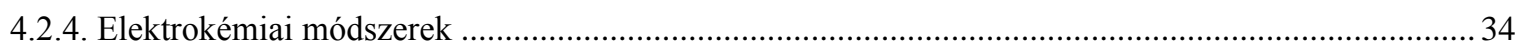

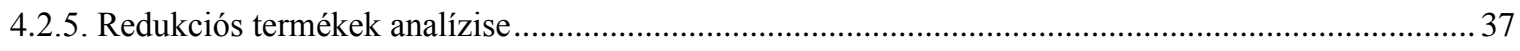

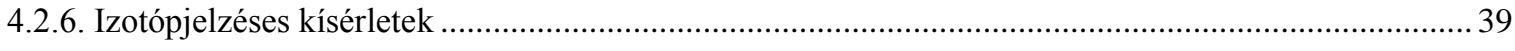

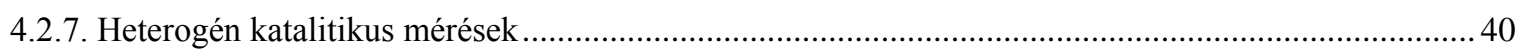

5. Eredmények és értékelésük ..................................................................................................................41

5.1. Szén-dioxid redukció mechanizmusának vizsgálata izotópjelzéses kísérletekkel...................................... 41

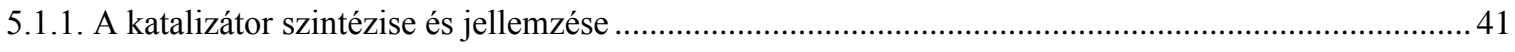

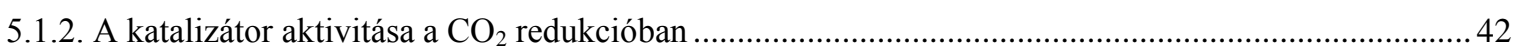


5.1.3. Szelektív izotópjelzéses kísérletek

5.1.4. Kontroll kísérletek 46

5.2. Nitrogénnel adalékolt szén elektródok pórusszerkezetének hatása a $\mathrm{CO}_{2}$ redukcióban 49

5.2.1. A különböző porozitású katalizátorok előállítása 49

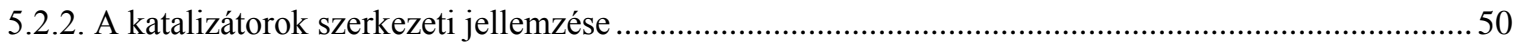

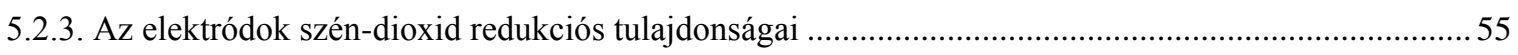

5.2.4. A katalizátor rétegvastagságának hatása a $\mathrm{CO}_{2}$ redukcióban..........................................................58

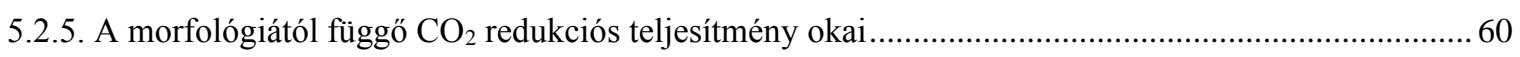

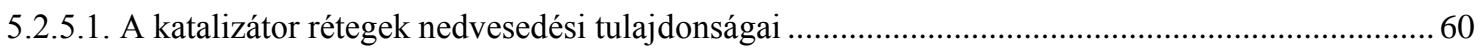

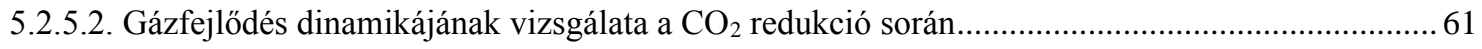

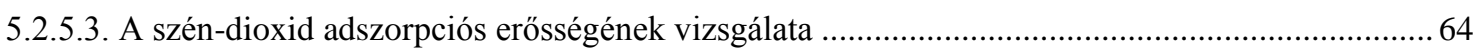

5.2.6. A szén-dioxid redukciós aktivitás - szelektivitás - stabilitás közötti összefüggések ........................... 65

5.3. Felületi funkciós csoportok szerepe nitrogénnel adalékolt szenek $\mathrm{CO}_{2}$ redukciós aktivitásában................. 68

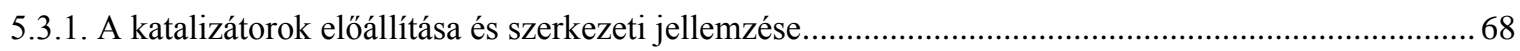

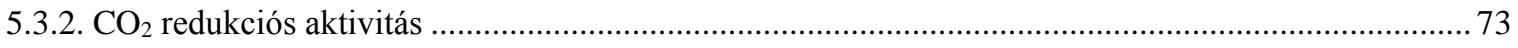

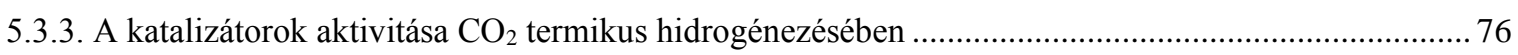

5.4. Fémmel és nitrogénnel adalékolt szén katalizátorok vizsgálata $\mathrm{CO}_{2}$ redukcióban és $\mathrm{H}_{2}$ fejlesztésben........ 78

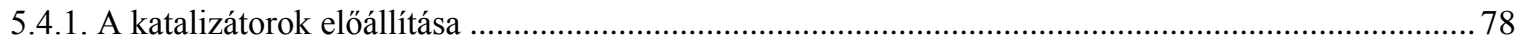

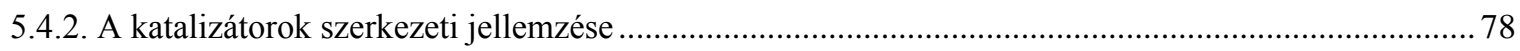

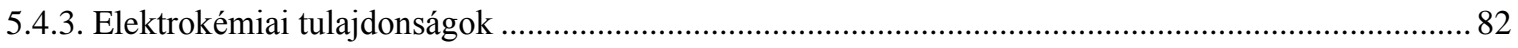

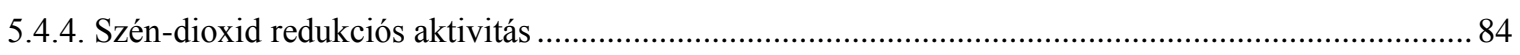

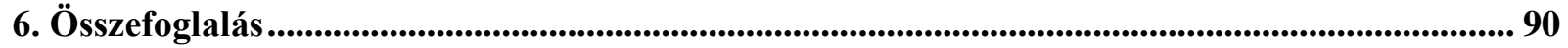

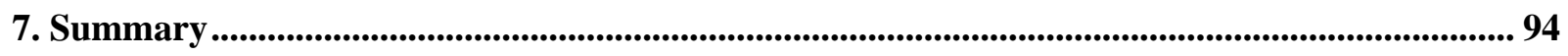

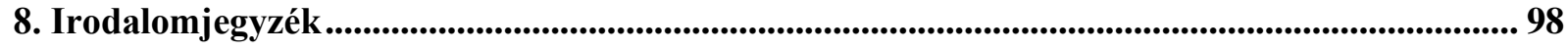

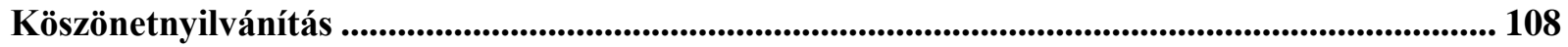




\section{Rövidítések listája}

BID: kisülési ionizációs detektor (barrier discharge ionization detector)

COF: kovalens szerves térháló

GC-BID: kisülési ionizációs detektorral felszerelt gázkromatográf

GC-MS: tömegspektrometriával kapcsolt gázkromatográfia

MOF: fémorganikus térháló

M-N-C: fémmel és nitrogénnel adalékolt szén

N-C: nitrogénnel adalékolt szén

N-CNT: nitrogén adalékolt szén nanocső

NMR: mágneses magrezonancia spektroszkópia

PANI: polianilin

PoPD: poli(o-feniléndiamin)

PPy: polipirrol

RHE: reverzibilis hidrogénelektród

RT: szobahőmérséklet

SEM: pásztázó elektronmikroszkóp

SHE: standard hidrogénelektród

TEM: transzmissziós elektronmikroszkóp

XPS: röntgen fotoelektron- spektroszkópia

XRD: röntgendiffrakció 


\section{Ábrajegyzék}

1. ábra: $\mathrm{A} \mathrm{CO}_{2}$ hasznosításának körfolyamata.

2. ábra: Egy laboratóriumi $\mathrm{CO}_{2}$ redukciós elektrolízis cella („H-típusú” cella) sematikus rajza. ........... 4

3. ábra: A négy kulcs paraméter, amit a $\mathrm{CO}_{2}$ redukciós katalizátorok fejlesztése során szem előtt kell tartani...

4. ábra: Elektrokémiai $\mathrm{CO}_{2}$ redukcióban vizsgált katalizátorok típusai......................................... 7

5. ábra: $\mathrm{A} \mathrm{CO}_{2}$ redukció egyszerüsített mechanizmusa fém elektródokon vizes közegben....................8 8

6. ábra: Egy N-adalékolt szén katalizátor sematikus szerkezete a különböző kémiai környezetü N-

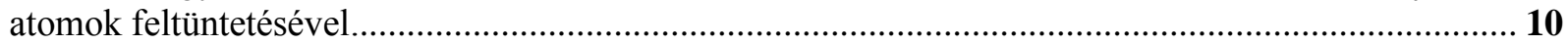

7. ábra: Nitrogénnel adalékolt szenek előállításának lehetőségei............................................... 11

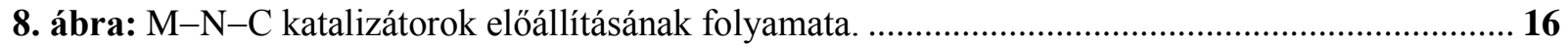

9. ábra: Morfológiai tényezők, melyek hatással vannak a nanoszerkezetü katalizátorok $\mathrm{CO}_{2}$ redukciós tulajdonságaira.

10. ábra: Az oldott $\mathrm{CO}_{2}$ eloszlási diagramja vizes közegben $0,5 \mathrm{M}$ és $0,1 \mathrm{M}$ teljes oldott széntartalom esetén.

11. ábra: $A \mathrm{CO}_{2}$ transzportja az elektródfelülethez diffúzióval és a hidrogén-karbonát ionok által

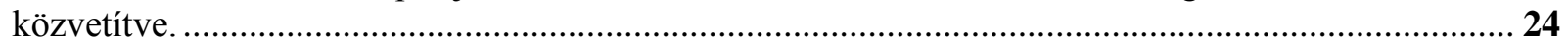

12. ábra: A doktori munkám célkitüzései................................................................................. 25

13. ábra: A pórusos N-C katalizátorok szintéziséhez használt szilika nanorészecskék TEM felvételei és a részecskeméret- eloszlás diagramok

14. ábra: A katalizátor rétegek készítéséhez használt porlasztva fújó készülék. ............................... 31

15. ábra: N-adalékolt szén katalizátorokban leggyakrabban előforduló N- típusok a hozzájuk tartozó kötési energiákkal.

16. ábra: Az elektródok kettősréteg kapacitásának meghatározása ciklikus voltammetriás mérésekből. (A): A ciklikus voltammogramról leolvasható a kettősréteg áram $\left(j_{d l}\right)$. (B): A $j_{d l}$ értékeket a pásztázási sebesség függvényében ábrázolva, a pontokra illesztett egyenes meredekségéből a kettősréteg kapacitás számítható.

17. ábra: Egy hidrogént, szén-monoxidot, metánt, etilént (mindegyik komponens $5 \mathrm{~V} / \mathrm{V} \%$, vivőgáz: $\mathrm{N}_{2}$ ) tartalmazó gázelegy kromatogramja Shincarbon ST típusú kolonnán elválasztva GC-BID müszerrel.

18. ábra: (A): A HPG-PPy katalizátor pásztázó elektronmikroszkópos képe. (B): A HPG-PPy elektród $\left(2,1 \mathrm{mg} \mathrm{cm}^{-2}\right.$ borítottság) és az üvegszén hordozó elektród ciklikus voltammogramja $\mathrm{CO}_{2}$-dal telített 0,5 $\mathrm{M} \mathrm{KHCO}_{3}$-oldatban, $50 \mathrm{mV} \mathrm{s}^{-1}$ pásztázási sebességgel. .

19. ábra: (A): A HPG-PPy elektród lineáris voltammogramja Ar-nal telített $0,5 \mathrm{M}$ foszfát-pufferben $(\mathrm{pH}=6,7)$ és $\mathrm{CO}_{2}$-dal telített $0,5 \mathrm{M} \mathrm{KHCO}_{3}$ oldatban $5 \mathrm{mV} \mathrm{s}^{-1}$ pásztázási sebességgel. (B): A HPG-PPy elektród kronoamperometriás görbéje $-0,7 \mathrm{~V}$-on $\mathrm{CO}_{2}$-dal telített $0,5 \mathrm{M} \mathrm{KHCO}_{3}$ oldatban. (C): $\mathrm{A}$ keletkező $\mathrm{CO}$ és $\mathrm{H}_{2}$ mennyisége az áthaladt töltés függvényében $-0,7 \mathrm{~V}$-on.

20. ábra: (A): $\mathrm{A} \mathrm{CO}_{2}$ redukció során ( $-0,7 \mathrm{~V}$ vs. RHE) keletkező $\mathrm{CO}$ GC-MS jele szelektív ion követés módban a kettős izotópjelzéses kísérlet során. $\mathrm{A}{ }^{12} \mathrm{CO}$ és a ${ }^{13} \mathrm{CO}$ molekulaionjához köthető $\mathrm{m} / \mathrm{z}=28$ és $\mathrm{m} / \mathrm{z}=29$ ionokat követtük. (B) A keletkező ${ }^{12} \mathrm{CO}$ és ${ }^{13} \mathrm{CO}$ arányának időbeli változása az elektrolízis során.

21. ábra: Egy zárt $\mathrm{HCO}_{3}{ }^{-} / \mathrm{CO}_{2}$ rendszerben a gázfázisú $\mathrm{CO}_{2}$ izotópösszetételének időbeli változása szelektív izotópjelzéses körülmények között, amennyiben a kiindulási hidrogén-karbonát só volt a ${ }^{13} \mathrm{C}$ jelzett.

22. ábra: $\mathrm{A}{ }^{13} \mathrm{CO}$ és a ${ }^{12} \mathrm{CO}$ koncentrációaránya $-0,7 \mathrm{~V}$-on szelektív izotópjelzéses körülmények között, amikor a $\mathrm{NaHCO}_{3}(\mathrm{~A})$, illetve a $\mathrm{CO}_{2}$ (B) volt az izotópjelzett komponens...

23. ábra: $\mathrm{A} \mathrm{H}_{2}$ - és $\mathrm{CO}$-fejlődés Faraday-hatásfoka -0,6 V-on (vs. RHE) az elektrolízis 75 . percében különbözö elektrolitokban: (i): $\mathrm{CO}_{2}$-dal telített $0,1 \mathrm{M}$ foszfát-puffer ( $\left.\mathrm{pH}=3,8\right)$; (ii): Ar-nal buborékoltatott $0,13 \mathrm{M} \mathrm{KHCO}_{3}(\mathrm{pH}=8,8) ; \mathrm{CO}_{2}$-dal telített $0,1 \mathrm{M} \mathrm{KHCO}_{3}(\mathrm{pH}=6,6) \ldots \ldots \ldots \ldots \ldots \ldots \ldots \ldots . . . .66$

24. ábra: A pórusos $\mathrm{N}-\mathrm{C}$ katalizátorok elóállításának folyamata..... 49 
25. ábra: A vizsgált $\mathrm{N}-\mathrm{C}$ katalizátorok transzmissziós (felső sor) és pásztázó (alsó sor) elektronmikroszkópos felvételei.

26. ábra: A vizsgált $\mathrm{N}-\mathrm{C}$ katalizátorok nagyfelbontású TEM képei.

27. ábra: A pórusos $\mathrm{N}-\mathrm{C}$ katalizátorok $\mathrm{N}_{2}$ adszorpciós / deszorpciós izotermái (A-C) és azokból a $\mathrm{BJH}$ módszerrel számított pórusméret-eloszlás görbék (D-F).

52

28. ábra: (A): Az NC-27 elektród (1,00 $\mathrm{mg} \mathrm{cm}^{-2}$ borítottság) ciklikus voltammogramjai különböző pásztázási sebességekkel Ar-nal buborékoltatott $1 \mathrm{M} \mathrm{Na}_{2} \mathrm{SO}_{4}$ oldatban. (B): A vizsgált $\mathrm{N}-\mathrm{C}$ elektródok ciklikus voltammogramjaiból meghatározott kettősréteg áramok pásztázási sebességtől való függése és az illesztett egyenesek meredekségéből meghatározott kettősréteg kapacitás értékek. (C): Összefüggés a katalizátor rétegek relatív érdessége és a BET-felületük között.

29. ábra: A különböző porozitású $\mathrm{N}-\mathrm{C}$ katalizátorok röntgendiffraktogramjai (A) és Raman-spektrumai (B). 53

30. ábra: Az NC-90 katalizátor nagy felbontású N1s (A) és C1s (B) XPS spektrumai.....................54 31. ábra: $A$ vizsgált $N-C$ katalizátorok különböző kémiai környezetű $N-(A)$ és $C-(B)$ atomjainak aránya. 55

32. ábra: (A): $\mathrm{Az} \mathrm{N}-\mathrm{C}$ elektródok $\mathrm{k}$ lineáris voltammogramjai $\mathrm{CO}_{2}$-dal telített $0,5 \mathrm{M} \mathrm{KHCO}_{3}$ oldatban $5 \mathrm{mV} \mathrm{s}{ }^{-1}$ pásztázási sebességgel. Az áramsürüségek az elektródok geometriai felületeire vonatkoznak. (B): A pórusos $\mathrm{N}-\mathrm{C}$ elektródok lineáris voltammogramjai, amennyiben az áramokat az elektródok valós elektrokémiai felületeivel normáltuk. (C): A lineáris voltammogramok potenciál szerinti derivált görbéi, melyekből a redukciós áramok indulási potenciáljait határoztuk meg. 56 33. ábra: (A) A potenciosztatikus elektrolízisek 40. percében mért teljes redukciós áramsürüségek $\mathrm{CO}_{2-}$ dal telített $0,1 \mathrm{M} \mathrm{KHCO}_{3}$ oldatban. (B) A moláris $\mathrm{CO} / \mathrm{H}_{2}$ arány a különböző pórusméretü katalizátorok esetén a potenciosztatikus elektrolízisek 40. percében.

34. ábra: $\mathrm{Az} \mathrm{N}-\mathrm{C}$ katalizátorok hidrogénfejlődésre (A) és $\mathrm{CO}$-fejlődésre vonatkozó parciális áramsürüségei a potenciosztatikus elektrolízisek 40. percében $0,1 \mathrm{M} \mathrm{KHCO} / \mathrm{CO}_{2}$ elektrolitban. Az áramsürüségek a geometriai felületre vonatkoznak.

35. ábra: $\mathrm{Az} \mathrm{NC}-27$ katalizátor különbözö borítottságú rétegeinek $\mathrm{CO}_{2}$ redukciós aktivitása. (A): Teljes áramsürüségek, (B): $\mathrm{CO} / \mathrm{H}_{2}$ mólarány, (C): Hidrogénfejlődés parciális áramsürüsége, (D): $\mathrm{CO}$ fejlődés parciális áramsürüsége. Az áramsürüségek a geometriai felületekre vonatkoznak.

36. ábra: (A): Dinamikus peremszög mérések az NC és az NC-27 katalizátorok esetén. (B): A vizsgált N-C katalizátorok peremszög hiszterézisekből számított látszólagos felületi energiái.

37. ábra: $\mathrm{Az} \mathrm{NC}-27$ elektródon potenciosztatikus elektrolízis közben fejlődő buborékok digitális mikroszkópos képe.

38. ábra: Buborékképződés dinamikájának tanulmányozása az $\mathrm{N}-\mathrm{C}$ elektródokon potenciosztatikus elektrolízis közben. (A): A távozó buborékok átméröje és tartózkodási ideje az NC-27 elektródon a potenciál függvényében. (B): A távozó buborékok átmérője és tartózkodási ideje a különböző pórusméretű minták esetén $-0,7 \mathrm{~V}$ (vs. RHE) potenciálon. (C): A buborékméretek eloszlása a pórusos minták esetén -0,7 V-on (vs. RHE). (D): A buborékok tartózkodási idejének eloszlása a pórusos minták esetén $-0,7 \mathrm{~V}$-on (vs. RHE).

39. ábra: $\mathrm{Az} \mathrm{N}-\mathrm{C}$ katalizátorok hőmérséklet programozott $\mathrm{CO}_{2}$ deszorpciós profiljai.

40. ábra: $\mathrm{Az} \mathrm{N}-\mathrm{C}$ elektródok rövidtávú stabilitásának vizsgálata. (A): A CO-fejlődés parciális áramának stabilitása a CO parciális áram függvényében. (B): A CO-fejlődés parciális árama és annak stabilitása az elektródpotenciál függvényében. (C): A CO-fejlődés parciális áramának stabilitása a $\mathrm{CO} / \mathrm{H}_{2}$ mólarány függvényében. (D): $\mathrm{A} \mathrm{H}_{2}$-fejlődés parciális áramának stabilitása a $\mathrm{H}_{2}$ parciális áram függvényében. (E): $\mathrm{A}_{2}$ parciális áram és annak stabilitása az elektródpotenciál függvényében. $(\mathrm{F})$ : a $\mathrm{H}_{2}$-fejlődés parciális áramának stabilitása a $\mathrm{CO} / \mathrm{H}_{2}$ mólarány függvényében függvényében.....

41. ábra: $\mathrm{Az} \mathrm{NC}-27$ elektród $\mathrm{SEM}$ felvételei $-0,6 \mathrm{~V}$ potenciálon végzett négy órás elektrolízis elött $(\mathrm{A})$ és után (B). Az átlagos pórusméret elektrolízis előtt 20,4 $\pm 3,2 \mathrm{~nm}$, míg elektrolízis után 22,7 \pm 3,9 nm 
volt. A teljes és parciális áramok $(\mathrm{C})$, valamint a $\mathrm{CO}$ - és a $\mathrm{H}_{2}$-fejlődés Faraday-hatásfokai (D) -0,6 Von $\mathrm{CO}_{2}$-dal telített $0,1 \mathrm{M} \mathrm{KHCO}_{3}$ oldatban a négyórás elektrolízis során...

42. ábra: A különböző prekurzorokból előállított és az utólagos kémiai kezeléseknek alávetett $\mathrm{N}-\mathrm{C}$ katalizátorok TEM felvételei.

43. ábra: A vizsgált katalizátorok $\mathrm{N}_{2}$ adszorpciós / deszorpciós izotermái.

44. ábra: Az adszorpciós izotermákból a $\mathrm{BJH}$ módszerrel számított pórusméret eloszlás görbék a PoPD$\mathrm{C}$ (A), PANI(30)-PoPD(70)-C, PoPD-C-NH $\mathrm{N}_{3}$ C) és a PoPD-C-KOH (D) minták esetén.

45. ábra: $\mathrm{A}$ PoPD-C (A); $\mathrm{PoPD}-\mathrm{C}-\mathrm{NH}_{3}$ (B) és a PoPD-C-KOH (C) katalizátorok ciklikus voltammogramjai Ar-nal buborékoltatott $1 \mathrm{M} \mathrm{Na}_{2} \mathrm{SO}_{4}$ oldatban különböző pásztázási sebességekkel. 71 46. ábra: (A) Összefüggés az elektródok relatív érdessége és BET felületük között. (B): A PoPD-C és a PoPD-C-NH $\mathrm{NH}_{3}$ elektródok elektrokémiai impedancia spektrumai Ar gázzal buborékoltatott $1 \mathrm{M} \mathrm{Na}_{2} \mathrm{SO}_{4}$ oldatban.

47. ábra: A vizsgált $\mathrm{N}-\mathrm{C}$ katalizátorok különböző kémiai környezetủ $\mathrm{N}$-atomjainak az aránya. (A: PoPD-C, B: PPy-C, C: PANI-C, D: PANI(70)-PoPD(30)-C, E: PANI(30)-PoPD(70)-C, F: PoPD-C-NH ${ }_{3}$, G: PoPD-C-KOH). 73

48. ábra: A potenciosztatikus elektrolízisek során mért teljes áramsűrüségek $(A, B)$, valamint a képződő $\mathrm{CO}$ és $\mathrm{H}_{2}$ mólaránya $(\mathrm{C}, \mathrm{D})$ a különböző prekurzorokból előállított $(\mathrm{A}, \mathrm{C})$ és utólagos kémiai kezeléseknek alávetett minták esetén (B,D)...

74

49. ábra: A relatív érdesség értékekkel normált $\mathrm{CO}$-fejlődésre vonatkozó parciális áramsürüségek az elektrolízis kísérletek 40. percében a különbözö prekurzorokból elöállított N-C katalizátorok (A), valamint az utólagos kémiai kezeléseknek alávetett PoPD-C minták esetén (B). Az elektródok borítottsága $1 \mathrm{mg} \mathrm{cm}^{-2}$ volt, a méréseket $\mathrm{CO}_{2}$-dal telített $0,1 \mathrm{M} \mathrm{KHCO}_{3}$ oldatban végeztük. 75

50. ábra: A képződő metán Faraday-hatásfoka a különböző katalizátorokon -0,9 V-on, az elektrolízisek 75. percében. (B): A képződő $\mathrm{CH}_{4}$ és $\mathrm{CO}$ mólaránya.

51. ábra: $\mathrm{A} C \mathrm{CO}$ és a $\mathrm{CH}_{4}$ képződési sebessége a $\mathrm{CO}_{2}$ termikus hidrogénezési reakciójában a különböző prekurzorból előállított N-C katalizátorok esetén. ..................................................................... 77

52. ábra: A vizsgált $\mathrm{M}-\mathrm{N}-\mathrm{C}$ katalizátorok röntgendiffraktogramjai.................................................79

53. ábra: $\mathrm{A} \mathrm{Cu}-\mathrm{N}-\mathrm{C}$ katalizátor $\mathrm{SEM}$ felvétele. ........................................................................... 79

54. ábra: $\mathrm{Az} \mathrm{M}-\mathrm{N}-\mathrm{C}$ katalizátorok TEM-felvételei. (A): $\mathrm{Ce}-\mathrm{N}-\mathrm{C},(\mathrm{B}): \mathrm{Cu}-\mathrm{N}-\mathrm{C},(\mathrm{C})$ : $\mathrm{Mo}-\mathrm{N}-\mathrm{C},(\mathrm{D})$ : $\mathrm{Pr}-\mathrm{N}-\mathrm{C}$.

55. ábra: $\mathrm{Az} \mathrm{M}-\mathrm{N}-\mathrm{C}$ katalizátorok nagyfelbontású XPS spektrumai. (A): $\mathrm{A} \mathrm{Cu}-\mathrm{N}-\mathrm{C} \mathrm{Cu} 2 \mathrm{p}$ spektruma. (B): A Cu-N-C N 1s spektruma. (C): A Mo-N-C Mo 3d spektruma.

56. ábra: (A): $\mathrm{A} \mathrm{Cu}-\mathrm{N}-\mathrm{C}$ elektródok ciklikus voltammogramjai három különböző borítottság esetén $\mathrm{CO}_{2}$-dal telített $0,5 \mathrm{M} \mathrm{KHCO}_{3}$-oldatban, $50 \mathrm{mV} \mathrm{s}^{-1}$ pásztázási sebességgel. (B): A három különböző borítottságú $\mathrm{Cu}-\mathrm{N}-\mathrm{C}$ elektród lineáris voltammogramjai $\mathrm{CO}_{2}$-dal telített $0,5 \mathrm{M} \mathrm{KHCO}_{3}$-oldatban $5 \mathrm{mV}$ $\mathrm{s}^{-1}$ pásztázási sebességgel.

57. ábra: A vizsgált $(\mathrm{M})-\mathrm{N}-\mathrm{C}$ katalizátorok és egy üvegszén elektród ciklikus voltammogramjai $\mathrm{CO}_{2-}$ dal telített $0,5 \mathrm{M} \mathrm{KHCO}_{3}$-oldatban $50 \mathrm{mV} \mathrm{s}^{-1}$ pásztázási sebességgel. Az (M)-N-C elektródok borítottsága $1,5 \mathrm{mg} \mathrm{cm}^{-2}$ volt. A ciklikus voltammogramokból meghatározott kettősréteg-kapacitás értékekből becsültük az elektródok elektrokémiailag aktív felületét.

58. ábra: (A): A vizsgált (M)-N-C elektródok lineáris voltammogramjai $\mathrm{CO}_{2}$-dal telített $0,5 \mathrm{M} \mathrm{KHCO}_{3}$ oldatban $5 \mathrm{mV} \mathrm{s}^{-1}$ pásztázási sebességgel. (B): A Cu-N-C elektród, egy rézlemez és egy üres üvegszén elektród lineáris voltammogramja $\mathrm{CO}_{2}$-dal telített $0,5 \mathrm{M} \mathrm{KHCO}_{3}$ oldatban $5 \mathrm{mV} \mathrm{s}^{-1}$ pásztázási sebességgel. (C): $\mathrm{A} \mathrm{Cu}-\mathrm{N}-\mathrm{C}$ lineáris voltammogramjai $\mathrm{CO}_{2}$ jelenlétében $\left(0,5 \mathrm{M} \mathrm{KHCO}_{3} / \mathrm{CO}_{2}\right)$ és annak hiányában $\left(0,5 \mathrm{M}\right.$ foszfát-puffer $\left./ \mathrm{N}_{2}\right) 5 \mathrm{mV} \mathrm{s}^{-1}$ pásztázási sebességgel.

59. ábra: $\mathrm{Az}(\mathrm{M})-\mathrm{N}-\mathrm{C}$ elektródok kronoamperometriás görbéi $\mathrm{CO}_{2}$-dal telített $0,5 \mathrm{M} \mathrm{KHCO}_{3}$-oldatban három különböző potenciálon $(-0,46 \mathrm{~V} ;-0,66 \mathrm{~V} ;-0,86 \mathrm{~V}$ vs. RHE) 86 60. ábra: $(A, B)$ : Az N-C elektródon képződő CO GC-MS jele szelektív ionkövetés $(\mathrm{m} / \mathrm{z}=28$ és $\mathrm{m} / \mathrm{z}=$ 29) módban, amennyiben nem izotópjelzett $\mathrm{NaH}^{12} \mathrm{CO}_{3}$ (A), és amennyiben izotópjelzett (B) $\mathrm{NaH}^{13} \mathrm{CO}_{3}$ 
elektrolit alkalmazásával végeztük a redukciót. (C, D): A képződő ${ }^{13} \mathrm{CO}$ és ${ }^{12} \mathrm{CO}$, amennyiben nem izotópjelzett $\mathrm{NaH}^{12} \mathrm{CO}_{3}(\mathrm{C})$ és amennyiben izotópjelzett (D) $\mathrm{NaH}^{13} \mathrm{CO}_{3}$ elektrolitot használtunk

61. ábra: $\mathrm{Az} \mathrm{M}-\mathrm{N}-\mathrm{C}$ elektródok katalitikus aktivitása a $\mathrm{CO}_{2}$ redukcióban és a hidrogénfejlesztésben. (A): Teljes redukciós áramsürüségek a potenciosztatikus elektrolízisek 30. percében három különböző elektródpotenciálon. (B): $\mathrm{A} \mathrm{CO}_{2}$ redukció és a hidrogénfejlődés parciális áramsürüségei a potenciosztatikus elektrolízisek 30 . percében $-0,66 \mathrm{~V}$ potenciálon.

62. ábra: Összefüggés a redukciós aktivitás (parciális áramsürüségek) és a katalizátorok felületi összetétele között.

\section{Táblázatok jegyzéke}

1. táblázat: $\mathrm{CO}_{2}$ redukciós félcella reakciók és a hozzájuk tartozó standard potenciál értékek $\left(25^{\circ} \mathrm{C}\right.$, $\mathrm{pH}=7$ ).

2. táblázat: $\mathrm{CO}_{2}$ redukcióban alkalmazott $\mathrm{N}-\mathrm{C}$ katalizátorok összefoglalása................................. 12

3. táblázat: A kontroll kísérletek során használt elektrolitok becsült $\mathrm{CO}_{2, \text { aq }}$ koncentrációja és $\mathrm{pH}-$ értéke elektrolízis előtt és után.

4. táblázat: Az N-C katalizátorok XPS mérésekből meghatározott elemi összetétele relatív atomszázalékban.

5. táblázat: A katalizátorok $\mathrm{N}_{2}$ adszorpciós izotermáiból meghatározott BET felületek, illetve az 1 $\mathrm{mg} \mathrm{cm}^{-2}$ borítottságú elektródok ciklikus voltammogramjaiból becsült relatív érdesség értékek.

6. táblázat: A különböző prekurzorokból előállított és utólagos kémiai kezelésnek alávetett N-C katalizátorok felületének elemi összetétele.

7. táblázat: A vizsgált katalizátorok elemi összetétele relatív atomszázalékban.

8. táblázat: A különböző kémiai környezetű $\mathrm{N}$-atomok eloszlása a vizsgált katalizátorokban relatív atomszázalékban kifejezve.

9. táblázat: $\mathrm{Az}(\mathrm{M})-\mathrm{N}-\mathrm{C}$ elektródok $\left(1,5 \mathrm{mg} \mathrm{cm}^{-2}\right.$ borítottság) elektrokémiailag aktív felületei 1 $\mathrm{cm}^{2}$ geomteriai felületre vonatkoztatva. 


\section{Bevezetés}

A Föld népessége az 1960-as évek óta napjainkra több, mint kétszeresére növekedett. Ezzel párhuzamosan az emberiség energiaigénye is évről-évre egyre nagyobb ütemben nő. Ennek több mint kétharmadát azonban ma is fosszilis energiahordozók (kőolaj, földgáz, szén) felhasználásával biztosítjuk ${ }^{1}$, melyek használata nagy mennyiségü szén-dioxidot juttat a légkörbe. Jelentős részben ezek az energiahordozók felelősek azért, hogy 2019-re ennek az üvegházhatású gáznak a légköri koncentrációja átlépte a korábban még soha nem tapasztalt 410 ppm-et. ${ }^{2}$ Bár a megújuló energiaformák részesedése is fokozatosan növekszik, áruk pedig jelentősen csökkent az utóbbi években; időszakos jellegük és egyenetlen területi eloszlásuk miatt az energiatárolás újszerủ megoldása szükséges. ${ }^{3}$

A szén-dioxid elektrokémiai redukciója ígéretes módszer lehet tüzelőanyagok és kémiai nyersanyagok elóállitására (1. ábra) ${ }^{4}{ }^{4}$ melyhez a szükséges energiát megújuló energiaforrásokkal (pl. Nap, szél) biztosíthatjuk. Ezáltal, mintegy újrahasznosítva a széndioxidot kémiai kötések formájában tárolhatjuk az energiát, mérsékelve a fosszilis tüzelőanyagoktól való függést és a hagyományos módszerek használata során jelentős $\mathrm{CO}_{2}$ emissziót. ${ }^{5}$ A folyamatban többek között olyan hasznos anyagokat állíthatunk elő, mint különböző alkoholok, szénhidrogének vagy szintézis gáz ( $\mathrm{CO} / \mathrm{H}_{2}$ elegy). Ezeket közvetlenül felhasználhatjuk például tüzelőanyag-cellákban, vagy kémiai prekurzorként tovább alakíthatjuk öket (pl. az etilén a müanyagipar egyik legfontosabb alapanyaga). ${ }^{6,7}$

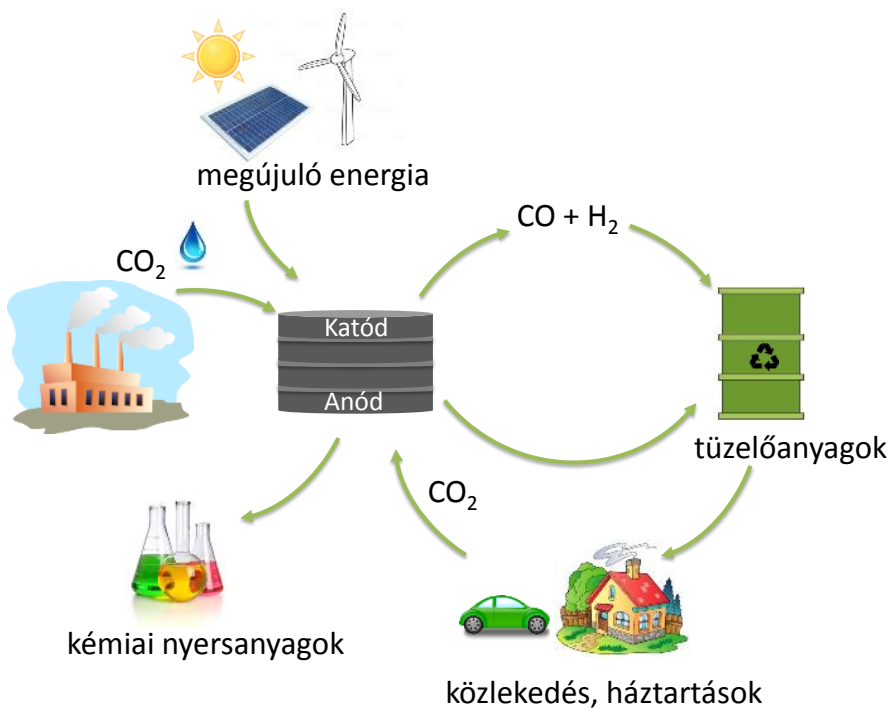

1. ábra: $\mathrm{A} \mathrm{CO}_{2}$ hasznosításának körfolyamata. 
A szén-dioxid elektrokémiai redukciója azonban csak akkor versenyezhet a fosszilis energiahordozók használatán alapuló termikus eljárásokkal (Fischer-Tropsch szintézis, Sabatier-eljárás, vízgőz reformálás), ha gazdaságilag is versenyképes lesz velük. ${ }^{6}$ Ehhez olcsó elektromos energiára és a folyamat energiahatékonyságának növelésére van szükség. ${ }^{5}$ Az utóbbi években jelentős előrelépést sikerült elérni a $\mathrm{CO}_{2}$ redukciós katalizátorok szelektivitásának, hatásfokának, és az elérhető reakciósebességek tekintetében, különösen a CO-fejlesztésre szelektív elektródok esetén. ${ }^{8}$ Valós ipari technológia megvalósulásához azonban további fejlesztések szükségesek nagy mennyiségben olcsón elöállítható, nagy stabilitású katalizátor anyagok és hatékony cellakonstrukciók irányába., ${ }^{4,9}$

A nitrogénnel adalékolt szenek ígéretes alternatívái lehetnek a hatékony, azonban drága nemesfém katalizátoroknak különbözö elektrokémiai folyamatokban, többek között a $\mathrm{CO}_{2}$ redukciójában is. ${ }^{10-12}$ Sok tekintetben azonban még nem ismerjük pontosan ezeknek az új generációs katalizátoroknak a $\mathrm{CO}_{2}$ redukciós teljesítményét meghatározó tényezőket. További szisztematikus vizsgálatok szükségesek, hogy átfogó ismereteket szerezzünk a müködési mechanizmusukról és a megállapított szerkezet-hatás összefüggések nyomán potenciális ipari katalizátorokká fejlesszük őket. 


\section{Irodalmi áttekintés}

\subsection{Az elektrokémiai szén-dioxid redukció}

A $\mathrm{CO}_{2}$ egy termodinamikailag stabil $(\mathrm{E}(\mathrm{C}=\mathrm{O})=750 \mathrm{~kJ} / \mathrm{mol})^{13}$, inert molekula, kémiai átalakításához jelentős energiabefektetés szükséges. Az elektrokémiai redukció során az elektrolízis cella katódján (2. ábra) az elektród anyagától, az alkalmazott elektródpotenciáltól és a kísérleti körülményektől függően különböző termékek képződhetnek (1. táblázat). ${ }^{11,14}$ Látható, hogy ezen proton csatolt elektrontranszfer reakciók standard potenciál értékei $\left(E^{\circ}\right)$ igen közel esnek egymáshoz, ami miatt gyakran termékek elegye keletkezik a folyamatban. Ez azonban többnyire nem kívánatos, hiszen a további felhasználás érdekében a termék komponenseket el kell választani. ${ }^{15} \mathrm{~A} \mathrm{CO}_{2}$ redukciója legtöbb esetben - környezetvédelmi szempontokat szem elött tartva - vizes közegben történik. A vizes közeg használata egyrészt előnyös, mivel ez biztosítja a reakcióhoz szükséges hidrogénionokat, azonban a hidrogénfejlődés gyakorlatilag elkerülhetetlen ebben az esetben. Emiatt a hidrogén tekinthető a folyamat legföbb melléktermékének. Fontos megjegyezni azonban, hogy éppen a versengő hidrogén fejlődés teszi lehetővé azt, hogy $\mathrm{CO} / \mathrm{H}_{2}$ elegyet, vagyis szintézisgázt állítsunk elö, ami fontos vegyipari termékek alapanyaga (pl. Fischer-Tropsch szintézis). ${ }^{16}$ Ebben az esetben a kihívást a $\mathrm{CO}$ és $\mathrm{H}_{2}$ arányának szabályozása jelenti.

1. táblázat: $\mathrm{CO}_{2}$ redukciós félcella reakciók és a hozzájuk tartozó standard potenciál értékek $\left(25^{\circ} \mathrm{C}\right.$, $\mathbf{p H}=7) .{ }^{11,14,17}$

\begin{tabular}{|c|c|}
\hline Félcella reakció & $\mathrm{E}^{\circ}$ (vs. SHE) / V \\
\hline $\mathrm{CO}_{2}+8 \mathrm{H}^{+}+8 e^{-}=\mathrm{CH}_{4}+2 \mathrm{H}_{2} \mathrm{O}$ & $-0,24$ \\
\hline $2 \mathrm{CO}_{2}+12 \mathrm{H}^{+}+12 e^{-}=C_{2} \mathrm{H}_{5} \mathrm{OH}+3 \mathrm{H}_{2} \mathrm{O}$ & $-0,33$ \\
\hline $2 \mathrm{CO}_{2}+12 \mathrm{H}^{+}+12 e^{-}=\mathrm{C}_{2} \mathrm{H}_{4}+4 \mathrm{H}_{2} \mathrm{O}$ & $-0,34$ \\
\hline $\mathrm{CO}_{2}+6 \mathrm{H}^{+}+6 e^{-}=\mathrm{CH}_{3} \mathrm{OH}+\mathrm{H}_{2} \mathrm{O}$ & $-0,38$ \\
\hline $2 H^{+}+2 e^{-}=H_{2}$ & $-0,41$ \\
\hline $\mathrm{CO}_{2}+4 \mathrm{H}^{+}+2 e^{-}=\mathrm{HCHO}+\mathrm{H}_{2} \mathrm{O}$ & $-0,50$ \\
\hline $\mathrm{CO}_{2}+2 \mathrm{H}^{+}+2 e^{-}=\mathrm{CO}+\mathrm{H}_{2} \mathrm{O}$ & $-0,53$ \\
\hline $\mathrm{CO}_{2}+2 \mathrm{H}^{+}+2 e^{-}=\mathrm{HCOOH}$ & $-0,61$ \\
\hline $\mathrm{CO}_{2}+e^{-}=\mathrm{CO}_{2}^{-}$ & $-1,9 \mathrm{~V}$ \\
\hline
\end{tabular}


A valóságban az egyensúlyi értékekhez képest sokszor lényegesen negatívabb potenciálon mennek végbe a fenti reakciók a folyamatok aktiválási sajátságai miatt. Ez az aktiválási túlfeszültség föként abból adódik, hogy az első elektron átlépése a lineáris $\mathrm{CO}_{2}$ molekulára - miközben egy hajlott szerkezetű gyökanion keletkezik - jelentős energiát igényel a strukturális átrendeződés miatt. ${ }^{14}$ Ehhez hozzáadódhat még a reakció során az elektród közelében a lokális $\mathrm{CO}_{2}$ koncentráció és $\mathrm{pH}$ változása miatt kialakuló koncentrációs túlfeszültség és többlépéses mechanizmus esetén reakció túlfeszültség is.

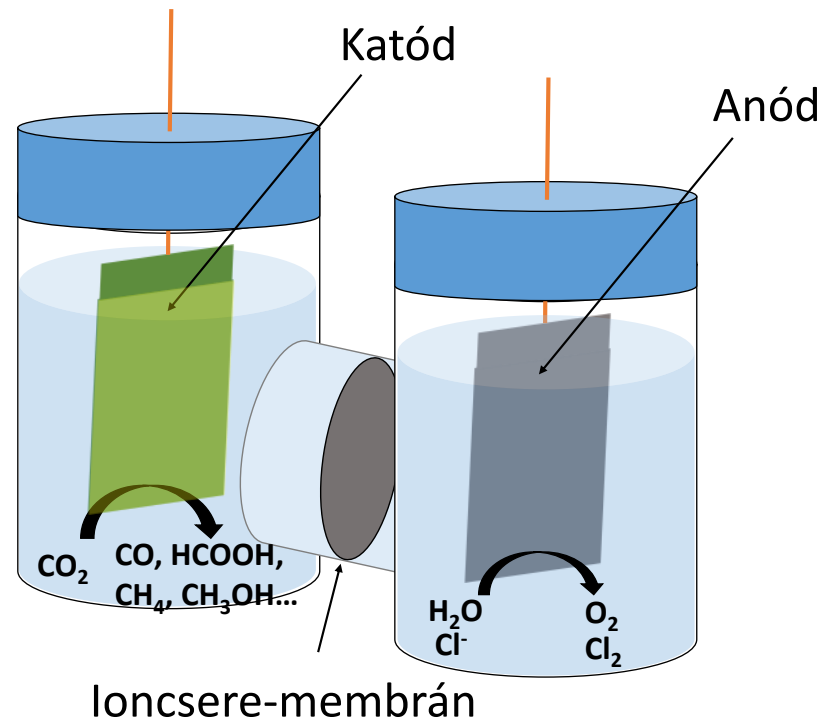

\section{2. ábra: Egy laboratóriumi $\mathrm{CO}_{2}$ redukciós elektrolízis cella („H-típusú” cella) sematikus rajza.}

A $\mathrm{CO}_{2}$ redukció során az anódreakció legtöbbször az oxigénfejlesztés, de egyre több alternatív reakciót vizsgálnak annak érdekében, hogy mindkét elektródon technológiailag hasznos termék képződjön. Jó megoldás lehet az anódos klórfejlesztés vagy a glicerin oxidációja hangyasavvá. Előbbi esetben a katódon keletkező tiszta $\mathrm{CO}$ és a $\mathrm{Cl}_{2}$ reakciójával foszgént lehetne előállítani, amely értékes alapanyag különböző vegyületek és polimerek elöállítása során. ${ }^{11}$ A glicerin (mely a biodízel és a szappangyártás mellékterméke) oxidációjával továbbá a $\mathrm{CO}_{2}$ elektrolízisének teljes energiaigényét is csökkenteni lehetne. ${ }^{18}$ 


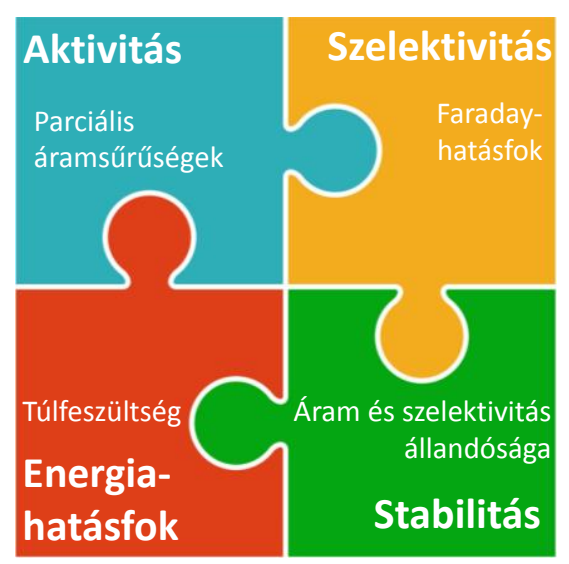

3. ábra: A négy kulcs paraméter, amit a $\mathrm{CO}_{2}$ redukciós katalizátorok fejlesztése során szem előtt kell tartani.

$\mathrm{Az}$ említett termodinamikai és kinetikai nehézségek kiküszöbölése, csökkentése érdekében a $\mathrm{CO}_{2}$ redukciós kutatások új elektrokatalizátorok fejlesztésére, a kísérleti körülmények optimalizálására és a megfelelő cellakonstrukció kialakítására törekszenek. Egy ideális katalizátornak (technológiának) összességében a következö szempontoknak kell megfelelnie (3. ábra): ${ }^{19}$

\section{- Szelektivitás:}

Elönyös, ha $\mathrm{CO}_{2}$ redukciójában egy, esetleg néhány termék keletkezik. A szelektivitás jellemzésére a Faraday-hatásfokot (FE vagy FE \%) használhatjuk, ami megmutatja, hogy az elektrolízis során áthaladt összes töltés hányad része vagy hány százaléka fordítódott az adott termék képződésére:

$$
F E(\boldsymbol{P})=\frac{z \cdot n(\boldsymbol{P}) \cdot F}{Q},
$$

ahol $z$ a $\boldsymbol{P}$ termék képződéséhez szükséges elektronok száma, $n$ a reakcióban képződött $\boldsymbol{P}$ termék anyagmennyisége, $F$ a Faraday-állandó, $Q$ a reakció során áthaladt összes töltés.

A Faraday-hatásfok meghatározásához a reakcióban keletkező összes termék minőségi és mennyiségi analízise szükséges (kromatográfiás módszerek, NMR-spektroszkópia, tömegspektrometria, stb.). Pontos termékanalízis esetén, egyéb mellékreakciók (pl. felületi oxid redukció) és nem Faraday-folyamatok (pl. adszorpció) hiányában a Faraday-hatásfokok összege $1(100 \%)$. 
- Aktivitás:

A katalizátor aktivitásán a termékek képződésének sebességét értjük, ami elektrokémiai folyamat esetén kifejezhető az áramsürüséggel. Adott termék képződési sebességét a parciális áramsürüség adja meg:

$$
j(\boldsymbol{P})=j_{\text {tot }} \cdot F E(\boldsymbol{P}),
$$

ahol $j(\boldsymbol{P})$ a $\boldsymbol{P}$ termék képződésére vonatkozó parciális áramsürüség, $j_{t o t}$ a redukciós folyamat során mér teljes áramsürüség, $F E(\boldsymbol{P})$ a $\boldsymbol{P}$ termék Faraday-hatásfoka.

Az áramsürüséget megadhatjuk az elektród geometriai felületére, valós elektrokémiai felületére, valamint a hordozó elektródra felvitt katalizátor tömegére vonatkoztatva is. Míg a geometriai felülettel és a tömeggel való normálás technológiai szempontból fontos, az elektrokémiai felületre vonatkozó áramsürüség a katalizátor saját aktivitásáról nyújt információt.

\section{- $\underline{\text { Stabilitás: }}$}

Ipari alkalmazás során egy elektrokatalizátornak akár több száz / ezer órás müködés során is stabilnak kell maradnia, mind az áramsürüség, mind pedig a szelektivitás tekintetében. ${ }^{20}$ Ezért katalizátorok fejlesztése során törekedni kell a mechanikai, kémiai, kristályszerkezeti és morfológiai stabilitásra is. Fontos továbbá, hogy az aktív helyek ne mérgeződjenek a termékek, köztitermékek hatására.

\section{- Energiahatásfok:}

$\mathrm{Az}$ energiahatásfok a keletkező termékekben tárolt kémiai energia és a felhasznált elektromos energia aránya. Ezt első sorban a reakció túlfeszültsége $\left(\eta=E-E^{\circ}\right)$ határozza meg. Redukció esetén minél kevésbé negatív az alkalmazott elektródpotenciál, annál gazdaságosabban valósítható meg a reakció. Az energiahatékonyság tekintetében fontos jellemző az a legkisebb túlfeszültség, amelynél elöször tapasztaljuk a vizsgált termék képződését ( $\left.\eta_{o n}\right)$, valamint amelynél a parciális áramsürüség elér egy meghatározott értéket (pl. $10 \mathrm{~mA} \mathrm{~cm}{ }^{-2}$ ). Az energiahatásfok $(\mathcal{E})$ kiszámítható a következö összefüggéssel ${ }^{21}$ :

$$
\varepsilon=\sum_{P} \frac{E_{c e l l, P}^{o} \cdot F E(\boldsymbol{P})}{E_{c e l l, P}^{o}+\eta_{\text {cell }}},
$$




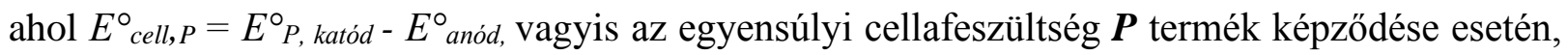
és $\eta_{\text {cell }}=\eta_{\text {anód }}+\eta_{\text {katód }}$, a cella túlfeszültsége. Látható, hogy nagy energiahatásfok nagy Faradayhatásfok és kis túlfeszültség esetén érhető el.

Végül fontos megjegyezni, hogy különböző katalizátorok teljesítményének összehasonlításakor kiemelt figyelmet kell fordítani a kísérleti körülmények (elektrolit koncentráció, összetétel, tisztaság) és a cellaelrendezés azonosságára. Ezáltal lehetünk biztosak abban, hogy a tapasztalt különbségek valóban az elektrokatalizátorok saját aktivitásbeli különbségeikből adódnak, nem pedig egyéb nem kívánt hatásokból. ${ }^{22}$

\subsection{A szén-dioxid redukció katalizátorai}

$\mathrm{Az}$ elektrokémiai $\mathrm{CO}_{2}$ redukcióban jelenleg a legelterjedtebben alkalmazott és legnagyobb teljesítményü katalizátorok a fémek. ${ }^{23-26}$ Ezen túl fém-oxidokat és kalkogenideket, fém-komplexeket (molekuláris katalizátorok), fémorganikus térhálókat (MOF) is széles körben vizsgálnak a folyamatban (4. ábra). ${ }^{14}$ Az utóbbi tíz évben a heteroatomokkal adalékolt szenek az érdeklődés középpontjába kerültek a $\mathrm{CO}_{2}$ redukcióban is. ${ }^{11,27-31} \mathrm{Ez}$ az újgenerációs katalizátor csoport valós alternatívát jelenthet a hatékony, azonban drága nemesfém katalizátorokkal szemben.

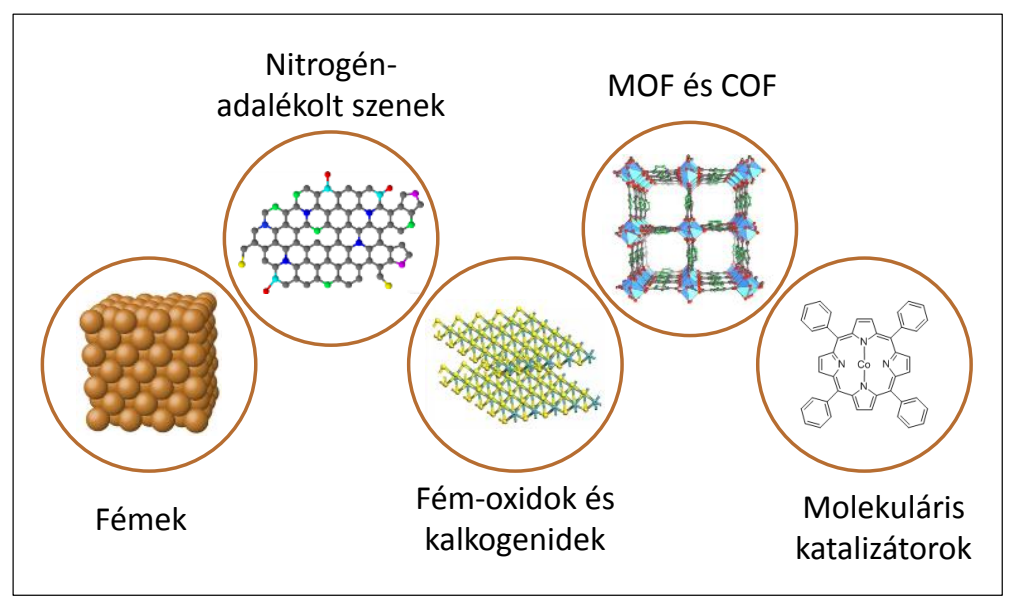

4. ábra: Elektrokémiai $\mathrm{CO}_{2}$ redukcióban vizsgált katalizátorok típusai.

\subsubsection{Fém katalizátorok}

A fémek vizsgálata az 1980-as évektől kezdődően (Yoshio Hori úttörő munkája) ${ }^{32}$ napjainkig központi helyet foglal el a $\mathrm{CO}_{2}$ redukciós katalizátorok kutatásában. Jelenleg a leghatékonyabb $\mathrm{CO}_{2}$ redukciós elektrokatalizátorok arany, ezüst, réz és ón 
nanoszerkezetek. ${ }^{14,24,25,33}$ A folyamat mechanizmusára vonatkozó ismereteink is legnagyobb mértékben ezeknek a fémeknek a vizsgálatából származnak.

A fémeket szelektivitásuk alapján három fő csoportba oszthatjuk. ${ }^{34}$ Az első csoportba tartozik az $\mathrm{Sn}, \mathrm{Hg}, \mathrm{Pb}$, In, melyeken hangyasav (vagy formiát ion) keletkezik fő termékként. A második csoport fémei (pl. Au, Ag, Zn) a CO képződését katalizálják. A réz, melyen különleges módon szénhidrogének és alkoholok képződése kedvezményezett, egyedül alkotja a harmadik csoportot. Bizonyos fémek $\mathrm{CO}_{2}$ redukciós aktivitása elhanyagolható, hidrogénfejlesztésben azonban igen aktívnak bizonyulnak (pl. Ni, Fe, Pt, Ti).

A katalizátorok szelektivitását elsősorban a köztitermékek katalizátor felülethez való kötődésének erőssége határozza meg (5. ábra). ${ }^{14} \mathrm{Az}$ első lépés minden esetben a $\mathrm{CO}_{2}$ kemiszorpciója, amit további proton- és elektrontranszfer lépések követnek. Az első csoport fémein a $\mathrm{COOH}^{*}$ köztitermék egy további proton és elektron felvétele közben hangyasavként deszorbeálódik. A második csoport esetén a $\mathrm{COOH}^{*}$ köztitermék erősen kötődik, ami lehetőséget biztosít egy további proton csatolt elektrontranszfer lépés megvalósulásához a katalizátor felületén. Az ekkor képződő CO* azonban gyengén kötődik, ami CO képződéséhez vezet. A réz és a CO* közötti kölcsönhatás erős, így az tovább alakulhat nagyobb energiatartalmú (többelektronos és / vagy több szénatomos) termékekké. A hidrogénfejlesztést elősegítő fémek esetén a CO* kötődése olyan erős, hogy sem a CO képződése (deszorpciója), sem pedig további redukció nem lehetséges, hanem a versengő hidrogénfejlesztés lesz meghatározó.

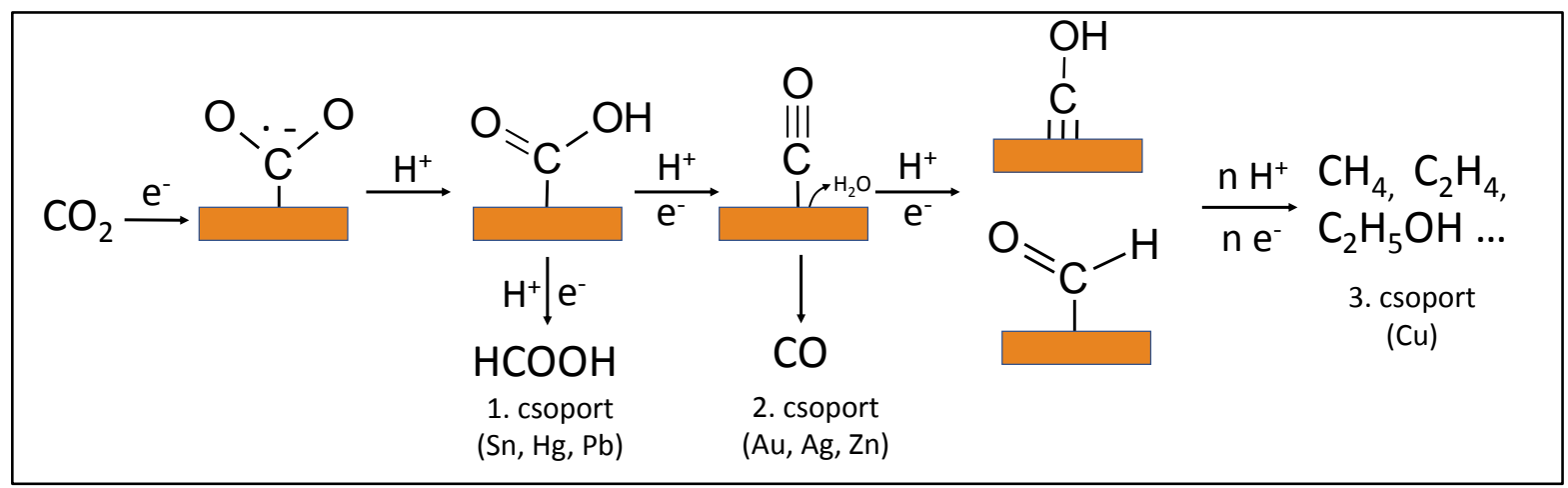

5. ábra: $\mathrm{A} \mathrm{CO}_{2}$ redukció egyszerüsített mechanizmusa fém elektródokon vizes közegben.

Fémek esetén a szükséges túlfeszültséget a sebességmeghatározó lépésben résztvevő, a felületen kötődő két köztitermék adszorpciós energiájának a különbsége határozza meg, mely a d-elektronok konfigurációjával van összefüggésben. Mivel lineáris összefüggés áll fent a (i) 
köztitermékek adszorpciós energiái (pl. $\mathrm{CO}^{*}$ és $\mathrm{COOH}^{*}$ ) között, valamint (ii) egy adott elemi lépésben a reaktáns intermedier adszorpciós energiája és az aktiválási energia között, a túlfeszültséget nem lehet egy bizonyos értéknél kisebbre csökkenteni. ${ }^{35}$ Ehhez az adszorpciós energiák között fennálló korreláció megszüntetésére lenne szükség, ami fémek esetén többek között nanoszerkezetek vagy többfémes rendszerek kialakításával, adalékolással, kompozitok képzésével vagy adszorpciós helyek beépítésével lehetséges. ${ }^{36}$ Tekintettel arra, hogy a szénalapú katalizátorok nem rendelkeznek $d$ elektronokkal, katalitikus teljesítményüket nem limitálják a fentebb említett lineáris összefüggések. Ez új lehetöséget jelent a $\mathrm{CO}_{2}$ redukciós katalizátorok kutatásában.

\subsubsection{Nitrogénnel adalékolt szén katalizátorok}

A heteroatomokkal (N, S, B) adalékolt szenek az utóbbi években egy intenzíven vizsgált katalizátorcsoporttá vált számos elektrokémiai folyamatban. A szén vázba beépített különböző kémiai környezetű heteroatomok módosítják a szén atomok töltés- és spinsürüségét, ami aktív centrumok kialakulásához vezet. ${ }^{35} \mathrm{~A} \mathrm{~N}$-adalékolt szén $(\mathrm{N}-\mathrm{C})$ katalizátorokat először a polimer elektrolit membrán (PEM) tüzelőanyagcellák nemesfém katód katalizátorainak kiváltására kezdték fejleszteni (oxigén redukciós reakció) ${ }^{37-39}$ Miután bebizonyosodott, hogy valóban alternatívát jelenthetnek a Pt-alapú katalizátorokkal szemben, más reakciókban, mint a vízoxidáció, hidrogénfejlesztés és a $\mathrm{CO}_{2}$ redukció is vizsgálni kezdték öket. ${ }^{40,41}$

\subsubsection{Szerkezet és tulajdonságok}

Az N-C katalizátorokban a N-atomok különböző kémiai környezetekben helyezkedhetnek el a szénvázban, melyek eltérő mértékben és módon járulnak hozzá a katalitikus aktivitáshoz. A leggyakoribb konfigurációk a piridines, a pirrolos, a grafitos, a cianidos, valamint az oxidált nitrogén (6. ábra). A különbözö N-atomok mennyiségének és típusának felderítésében legfontosabb módszer a nagy felbontású röntgen fotoelektronspektroszkópia (XPS). ${ }^{42}$ 


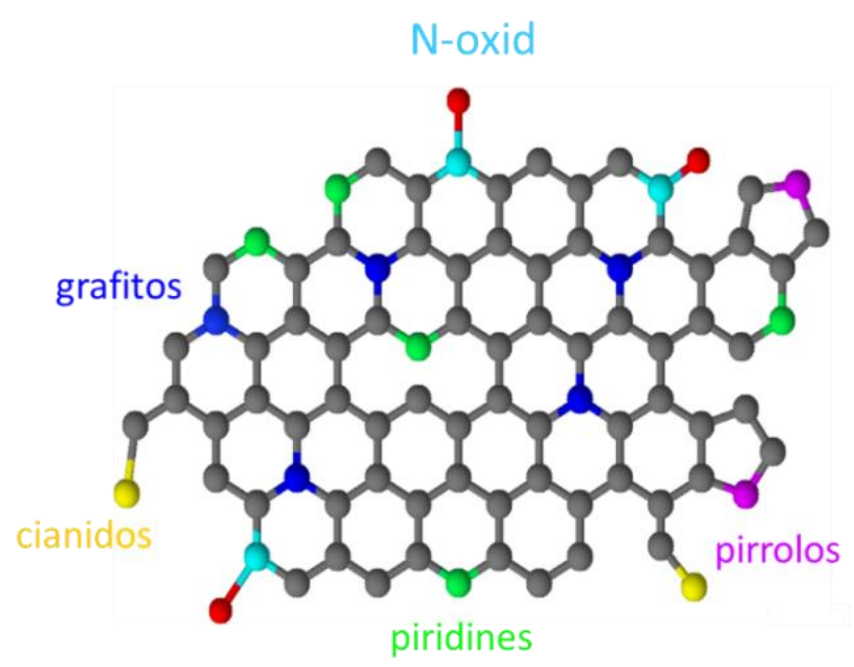

6. ábra: Egy N-adalékolt szén katalizátor sematikus szerkezete a különböző kémiai környezetű N- atomok feltüntetésével.

Az N-C katalizátorok számos előnyös tulajdonsággal rendelkeznek a fémekhez képest: ${ }^{14,35}$

- Viszonylag egyszerü módszerekkel, költséghatékonyan elöállíthatók, mely során tulajdonságaik hangolhatók;

- Nagy fajlagos felületük és pórusos szerkezetük miatt nagy lehet az elérhető aktív centrumok száma, valamint a $\mathrm{CO}_{2}$ adszorpciós kapacitásuk;

- A grafitosság mértékétől függően kiváló elektromos vezetők lehetnek;

- A bázikus $\mathrm{N}$-atomok kémiai kölcsönhatásba lépve a reaktáns $\mathrm{CO}_{2}$ molekulával, segíthetik annak aktiválódását; ${ }^{43}$

- A szénváz kémiailag inert, a fémeknél előforduló kristályszerkezeti átrendeződések vagy a nanorészecskék esetén tapasztalt aggregálódás nem jellemző;

- Jó a mechanikai-, hő-, és pH-stabilitásuk.

\subsubsection{Előállítási lehetőségek}

Az N-C katalizátorok előállítása két alapvető módon lehetséges: ${ }^{10}$ (i) in situ szintézissel és (ii) szenek utólagos nitrogén adalékolásával (7. ábra). Az in situ szintézis során egy szén- és egy nitrogén tartalmú prekurzorból például kémiai gőzfázisú leválasztással (CVD), hidrotermális karbonizálással vagy magas hőmérsékletű pirolízissel kaphatjuk a N-adalékolt szeneket. Gyakori szén prekurzor az acetilén; nitrogén prekurzorként többek között ammóniát, melamint, N-tartalmú polimereket használnak. ${ }^{4-46}$ Gyakori, hogy a szén- és a nitrogén 
prekurzor megegyezik. A második módszer során már meglévő szenekből (pl. grafén, szén nanocső) valamely nitrogén prekurzorral (ammónia, karbamid) történő utólagos adalékolással (együttes hőkezelés vagy nedves kémiai eljárást követő hőkezelés) állíthatjuk elő a kívánt katalizátort. ${ }^{10,44}$

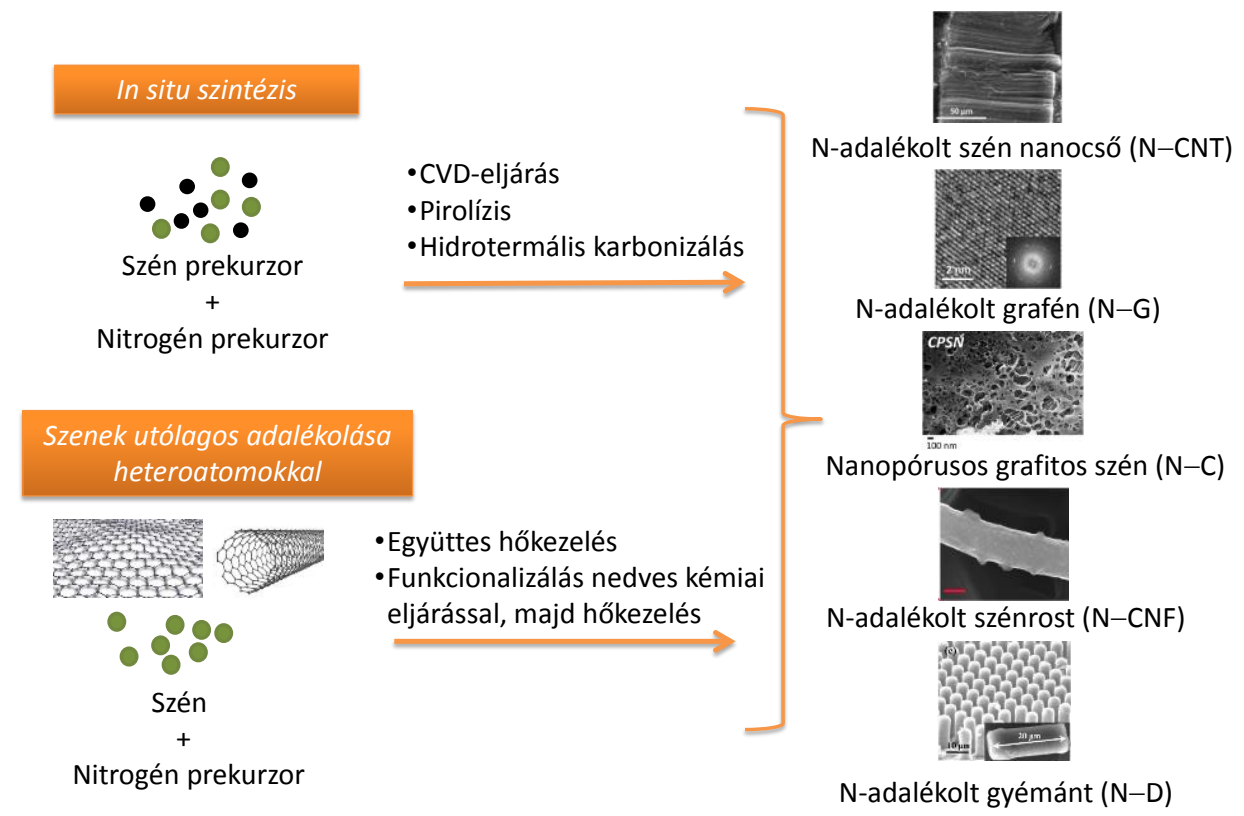

\section{7. ábra: Nitrogénnel adalékolt szenek előállításának lehetőségei. ${ }^{4-50}$}

A szintézis során a pirolízis / utólagos hőkezelés hőmérsékletének és a prekurzorok minőségének megválasztásával egyszerủen hangolhatjuk a fajlagos felületet, porozitást, grafitosság mértékét és N-tartalmat. ${ }^{50}$ Utóbbi általában 1 és 10 atom\% között változik. Ezekkel az eljárásokkal különböző N-adalékolt szén allotrópokat kaphatunk, melyek még azonos Ntartalom esetén is jelentősen különbözö katalitikus aktivitással bírhatnak. Fontos továbbá, hogy a szintézis során használt esetleges fém katalizátorok (pl. CVD-szintézis) maradványait teljes mértékben eltávolítsuk, hiszen a fém szennyezések is hozzájárulhatnak a $\mathrm{CO}_{2}$ redukciós aktivitáshoz. ${ }^{51}$ Teljesen fémmentes szintézissel kapott $\mathrm{N}-\mathrm{C}$ katalizátorok $\mathrm{CO}_{2}$ redukciós aktivitása azonban azt igazolja, hogy a katalitikus aktivitás nem elsősorban az esetleges fém szennyezéseknek tudható be, hanem sokkal inkább a heteroatomok jelenlétének. ${ }^{52}$

Az elektrokémiai vizsgálatokhoz az előállított katalizátorokból elektródot kell készíteni. Ennek során hordozó elektródra (pl. üvegszén lemez, gázdiffúziós réteg) visszük fel a szén 
katalizátort, többek között sprézéssel, cseppentéssel vagy festéssel. Az elektród készítésének módja szintén jelentős hatással lehet a katalitikus aktivitásra morfológiai különbségek miatt. ${ }^{53}$

\subsubsection{Alkalmazás szén-dioxid redukcióban}

A legtöbb vizsgált $\mathrm{N}-\mathrm{C}$ katalizátor $\mathrm{CO}$ vagy $\mathrm{HCOOH}$ képződését katalizálja a $\mathrm{CO}_{2}$ redukciójában. Sok tekintetben megközelítik, vagy akár felülmúlják a fém katalizátorok teljesítményét azonos kísérleti körülmények között. A heteroatomokkal való adalékolás szükségszerüségét mutatja, hogy a tiszta (nem adalékolt) szenek csupán marginális aktivitást mutatnak a reakcióban. ${ }^{52,54}$ A következökben a teljesség igénye nélkül kiemelném a N-C elektródokon a $\mathrm{CO}_{2}$ redukciójában elért legfontosabb eredményeket (2. táblázat).

2. táblázat: $\mathrm{CO}_{2}$ redukcióban alkalmazott N-C katalizátorok összefoglalása.

\begin{tabular}{|c|c|c|c|c|c|c|}
\hline Katalizátor & $\begin{array}{l}\text { Hordozó } \\
\text { elektród }\end{array}$ & Elektrolit & $\begin{array}{c}\text { Maximális } \\
\mathrm{CO}_{2} \\
\text { redukciós FE } \\
/ \%\end{array}$ & $\begin{array}{l}\text { Elektród } \\
\text { potenciál }\end{array}$ & Áramsűrűség & Ref. \\
\hline $\begin{array}{l}\mathrm{N} \text {-adalékolt } \\
\text { mezopórusos szén }\end{array}$ & szénpapír & $\begin{array}{c}0,1 \mathrm{M} \\
\mathrm{KHCO}_{3}\end{array}$ & $80 \% \mathrm{CO}$ & $-0,6$ V vs. RHE & $\mathrm{j}_{\mathrm{CO}}=-2,9 \mathrm{~mA} \mathrm{~cm}^{-2}$ & 55 \\
\hline $\begin{array}{c}\mathrm{N} \text {-adalékolt pórusos } \\
\text { szén }\end{array}$ & üvegszén & $\begin{array}{c}0,1 \mathrm{M} \\
\mathrm{KHCO}_{3}\end{array}$ & $84 \% \mathrm{CO}$ & $-0,6$ V vs. RHE & $\mathrm{j}_{\mathrm{CO}}=-1,2 \mathrm{~mA} \mathrm{~cm}-2$ & 46 \\
\hline $\begin{array}{c}\mathrm{N} \text {-adalékolt grafén } \\
\text { nanoszalag }\end{array}$ & szénpapír & $\begin{array}{c}0,5 \mathrm{M} \\
\mathrm{KHCO}_{3}\end{array}$ & $87 \% \mathrm{CO}$ & $-0,4$ V vs. RHE & $\mathrm{j}_{\mathrm{CO}}=-6,1 \mathrm{~mA} \mathrm{~cm}-2$ & 45 \\
\hline $\begin{array}{l}\text { N,P-adalékolt } \\
\text { mezopórusos szén }\end{array}$ & szénpapír & $\begin{array}{l}0,1 \mathrm{M} \\
\mathrm{KHCO}_{3}\end{array}$ & $\begin{array}{c}62 \% \mathrm{CO}, \\
\text { nyomnyi metán }\end{array}$ & $-0,7 \mathrm{~V}$ vs. RHE & $\mathrm{j}_{\mathrm{CO}}=-3,0 \mathrm{~mA} \mathrm{~cm}{ }^{-2}$ & 56 \\
\hline $\begin{array}{c}\text { N-adalékolt szén } \\
\text { nanorost }\end{array}$ & - & 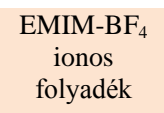 & $98 \% \mathrm{CO}$ & $\begin{array}{c}-0,57 \mathrm{~V} \text { vs. SHE } \\
(\mathrm{pH}=5,54)\end{array}$ & $\mathrm{j}_{\mathrm{CO}}=-3,4 \mathrm{~mA} \mathrm{~cm}^{-2}$ & 52 \\
\hline $\begin{array}{c}\text { Polietiléniminnel } \\
\text { bevont N-CNT }\end{array}$ & üvegszén & $\begin{array}{c}0,1 \mathrm{M} \\
\mathrm{KHCO}_{3}\end{array}$ & $87 \% \mathrm{HCOOH}$ & $-1,8 \mathrm{~V}$ vs. SCE & $\mathrm{j}_{\mathrm{CO}}=-6.3 \mathrm{~mA} \mathrm{~cm}^{-2}$ & 31 \\
\hline $\mathrm{N}$-adalékolt grafén & szénpapír & $\begin{array}{c}0,5 \mathrm{M} \\
\mathrm{KHCO}_{3}\end{array}$ & $73 \% \mathrm{HCOOH}$ & - 0,84 V vs. RHE & $\begin{array}{c}\mathrm{j}_{\text {нсоОН }}=-5,5 \mathrm{~mA} \\
\mathrm{~cm}^{-2}\end{array}$ & 57 \\
\hline $\begin{array}{l}\mathrm{N} \text {-adalékolt } \\
\text { mezopórusos szén }\end{array}$ & szénpapír & $\begin{array}{l}0,1 \mathrm{M} \\
\mathrm{KHCO}_{3}\end{array}$ & $77 \% \mathrm{C}_{2} \mathrm{H}_{5} \mathrm{OH}$ & - 0,56 V vs.RHE & $\mathrm{j}_{\mathrm{tot}}=-0,2 \mathrm{~mA} \mathrm{~cm}^{-2}$ & 27 \\
\hline $\mathrm{N}$-adalékolt grafén & szénpapír & $\begin{array}{c}{[\mathrm{Bmim}] \mathrm{BF}_{4}} \\
\text { ionos } \\
\text { folyadék }\end{array}$ & $\begin{array}{c}93,5 \% \mathrm{CH}_{4} \\
4,2 \% \mathrm{CO}\end{array}$ & $-1,4 \mathrm{~V}$ vs. $\mathrm{Ag} / \mathrm{Ag}^{+}$ & $\mathrm{j}_{\mathrm{CH} 4}=-1,3 \mathrm{~mA} \mathrm{~cm}^{-2}$ & 29 \\
\hline
\end{tabular}

A $\mathrm{CO}_{2}$ redukcióban alkalmazott első fémmentes $\mathrm{N}-\mathrm{C}$ katalizátor egy $\mathrm{N}$-adalékolt szén nanorost volt. ${ }^{52}$ Ionos folyadékban $98 \%$-os szelektivitással, elhanyagolható túlfeszültség mellett képződött a CO. Az áramsürüség több mint egy nagyságrenddel meghaladta az összehasonlításként használt $\mathrm{Ag}$ katalizátoron mértet. Egy $\mathrm{N}$-adalékolt szén nanocsövön 
(N-CNT) a maximális CO Faraday-hatásfok (80\%) eléréséhez mindössze -0,26 V túlfeszültség kellett, ami kisebb volt, mint a legtöbb $\mathrm{Ag}$ és Au katalizátor esetén. ${ }^{54} \mathrm{Ez}$ továbbá nagy stabilitással párosult, mind az áramsürüség, mind pedig a szelektivitás tekintetében. Egy Nadalékolt szén / többfalú szén nanocső kompoziton 98 \%-os CO szelektivitást és kiemelkedö, 90 $\mathrm{mA} \mathrm{cm}{ }^{-2} \mathrm{CO}$ parciális áramsürüséget sikerült elérni folyamatos áramlásos cellában. ${ }^{58} \mathrm{~A}$ szén nanocsövek mellett N-adalékolt grafén és mezopórusos szén katalizátorok is aktívnak bizonyultak CO fejlesztésében, előnyük a fémekhez képest szintén első sorban a kis túlfeszültségekben nyilvánult meg. ${ }^{45,46,57,59}$ A közelmúltban azt is megmutatták, hogy a nitrogénatomok mellett szekunder heteroatomok $(F, S)$ jelenléte szinergikus hatás révén tovább növelheti a $\mathrm{CO}_{2}$ redukciós aktivitást. ${ }^{60,61}$

A CO mellett a hangyasav a másik leggyakoribb termék fémmentes $\mathrm{N}-\mathrm{C}$ katalizátorokon. Többek között $\mathrm{N}$-adalékolt grafén-oxidon ${ }^{57}$, ammónia plazmával kezelt szén nanocsövön vagy polietiléniminnel bevont szén nanocsövön ${ }^{31}$ is ez volt a fö termék. Érdekes, hogy a hasonló N-tartalmú és konfigurációjú N-CNT katalizátorokon, az előállítás módjától függően változott a szelektivitás: az ammóniával kezelt nanocsövön formiát ${ }^{31}$, míg a CVD eljárással elóállított $\mathrm{N}-\mathrm{CNT}$ katalizátoron $\mathrm{CO}$ keletkezett. ${ }^{54}$ Jó mechanikai stabilitású, hierarchikusan pórusos $\mathrm{N}-\mathrm{C}$ membránt gázdiffúziós elektródként alkalmazva jó aktivitást, szelektivitást és hosszútávú stabilitást értek el hangyasav fejlesztésében, amit részben a kedvező pórusszerkezetnek tulajdonítottak. ${ }^{59}$ Ezek a tapasztalatok arra utalnak, hogy a heteroatomokon túl egyéb faktorok is (mint a szénváz szerkezete) jelentős hatással bírhatnak a redukciós tulajdonságok meghatározásában.

A kételektronos $C_{1}$ termékeken túl néhány esetben szénhidrogének és alkoholok képződését is megfigyelték N-adalékolt szeneken. Ionos folyadékban közel 93\%-os szelektivitással keletkezett metán, 3-piridinkarbonitril prekurzorból elöállított $\mathrm{N}-\mathrm{C}$ katalizátoron. ${ }^{62} \mathrm{~N}$ - adalékolt grafén kvantumpöttyökön metán, etilén, metanol, acetát és propanol is képződött. Folyamatos áramlásos cellában az etilénre és az etanolra mért parciális áramsürüségek összemérhetőek voltak $\mathrm{Cu}$ nanorészecskék esetén tapasztalttal. ${ }^{63} \mathrm{~A} \mathrm{C}-\mathrm{C}$ kötés kialakulásának mechanizmusát kísérletileg nem bizonyították, de az éleken akkumulálódó piridines nitrogénatomok részvételét valószínüsítették. ${ }^{63} \mathrm{~A}$ kvanumpöttyökön képződő sokféle termékkel szemben hengeres pórusokkal rendelkező N-tartalmú szénen közel 100\%-os 
szelektivitással etanol keletkezett. ${ }^{27}$ Ebben az esetben feltételezték, hogy a CO köztitermékek dimerizálódását a katalizátor csatornaszerủ morfológiája segítette elő.

Összességében a N-adalékolt szenek ígéretes katalizátorok lehetnek hangyasav és CO (vagy szintézisgáz) előállítására, azonban a redukciós áramsürüségek további növelése szükséges potenciális ipari alkalmazás eléréséhez. Erre lehetőség nyújthat például kiemelkedően nagy fajlagos felületủ anyagok alkalmazása, az aktív centrumok sürüségének és elérhetőségének növelése, illetve fém heteroatomok beépítése az N-C struktúrába. Szén-alapú katalizátorok esetén továbbá kiemelten fontos, hogy a $\mathrm{CO}_{2}$ redukciós termékek eredetét ${ }^{13} \mathrm{C}$ izotópjelzéses kísérletekkel igazoljuk. ${ }^{27,45,62}$ Ezáltal megbizonyosodhatunk arról, hogy a keletkező termékek valóban a $\mathrm{CO}_{2}$ átalakításából származnak, nem pedig a katalizátor esetleges degradálódásából. Izotópjelzéses kísérletek továbbá reakciómechanizmus felderítésére is alkalmasak lehetnek. ${ }^{64,65}$

\subsubsection{Aktív centrumok a szén-dioxid redukcióban}

Az aktív centrumok felderítése kulcskérdés katalizátorok fejlesztése során. Ez a Nadalékolt szenek esetén igen nagy kihívást jelent tekintettel arra, hogy ezeknek az anyagoknak a szerkezete sokszor nem jól definiált. Ráadásul gyakran többféle aktív centrum található egyetlen anyagban és az elóállítási körülmények változtatása nemcsak a N-tartalmat módosíthatja, hanem a grafitosságot, porozitást és a morfológiát is. Ezek viszont szintén hatással lehetnek a katalitikus tulajdonságokra.

$\mathrm{A} \mathrm{CO}_{2}$ redukcióban aktív centrumokként a különböző típusú nitrogénatomokat és / vagy az azokkal szomszédos parciális pozitív töltésủ szénatomokat valószínüsítik. Legtöbb esetben az előállítás során próbálják szisztematikusan szabályozni a N-tartalmat és típust, ${ }^{45,66} \mathrm{de}$ az általános szintetikus stratégiákkal nem lehet elérni, hogy csupán egyféle kémiai környezetben lévő nitrogénatomot tartalmazzon egy anyag. Találhatunk példát arra is, hogy bizonyos Nkonfigurációk szelektív eltávolításával vagy blokkolásával hangolták a N-tartalmat. ${ }^{55,67}$ Ezt követően általában a röntgen-fotoelektron spektroszkópiával meghatározott $\mathrm{N}$-tartalom és a $\mathrm{CO}_{2}$ redukciós parciális áramok között keresnek korrelációt. ${ }^{47}$ Ezt kiegészítheti az elektródokról $\mathrm{CO}_{2}$ redukció elött és után felvett XPS spektrumok összehasonlítása, melynek során a Nkonfigurációk változását vizsgálják. Ezen túl gyakran elméleti számítások segítségével 
magyarázzák a tapasztalt trendeket (köztitermékek kötési energiáinak számítása a különböző típusú $\mathrm{N}$-atomokon). ${ }^{45}$

A katalizátorok N-tartalmát és a különböző típusú $\mathrm{N}$ atomok arányát (i) a prekurzorok arányával, (ii) a karbonizálás hőmérsékletével valamint (iii) $\mathrm{H}_{2}$-nel és foszforsavval való utólagos reakcióval is hangolták egy munkában. ${ }^{45}$ ( $\mathrm{A} \mathrm{H}_{2}$ különböző hőmérsékleteken más-más típusú $\mathrm{N}$-atommal reagál, míg a foszforsav szelektíven adszorbeálódik a piridines $\mathrm{N}$-atomokon). Minden esetben a piridines nitrogénatomok mennyisége korrelált a $\mathrm{CO}_{2}$ redukciós aktivitással. Egy másik munkában azt figyelték meg, hogy nagyobb piridines $\mathrm{N}$-tartalmat lehet elérni a szintézis során ammónia atmoszférában történő hőkezelés által az inert atmoszférához képest. Ez pedig szintén a $\mathrm{CO}_{2}$ redukciós aktivitás növekedésével járt együtt. ${ }^{46}$

Jelenleg leginkább elfogadott álláspont, hogy a piridines $\mathrm{N}$-atomok az aktív helyek a $\mathrm{CO}_{2}$ redukcióban, de van példa arra is, hogy a grafitos-, a pirrolos nitrogént, vagy a nitrogénatomokkal szomszédos szénatomokat valószínüsítik. ${ }^{57,67,68} \mathrm{Az}$ sem kizárt továbbá, hogy különböző típusú anyagokban más-más centrumok felelősek a redukcióért. Direkt kísérleti bizonyíték hiányában, illetve a fentebb is említett kémiai és strukturális inhomogenitások miatt azonban ez továbbra is nyitott kérdés az $\mathrm{N}-\mathrm{C}$ katalizátorok $\mathrm{CO}_{2}$ redukciós mechanizmusának felderítésében.

\subsubsection{Fémmel és nitrogénnel adalékolt szén katalizátorok}

Fémcentrumok beépítése a $\mathrm{N}$-adalékolt szén vázba eredményes stratégiának bizonyult a katalitikus áramsürüségek növelésében. ${ }^{17,69}$ Ezekben a fémmel és nitrogénnel adalékolt szenekben $(\mathrm{M}-\mathrm{N}-\mathrm{C})$ a fémek izoláltan, atomosan eloszlatva találhatóak, így átmenetet képeznek a molekuláris katalizátorok és a heterogén katalizátorok között. ${ }^{11}$ Előnyük, hogy nem szükséges drága nemesfémeket alkalmazni: olcsóbb átmenetifémekkel ( $\mathrm{Fe}, \mathrm{Ni}, \mathrm{Co}, \mathrm{Cu}, \mathrm{Mn}$ ) is nagy katalitikus teljesítmény érhető el. Az angol nyelvủ szakirodalomban gyakran használják erre a katalizátorcsoportra az „atomi katalizátor” (,single atom catalyst”) vagy a „nemnemesfém katalizátor” („,non-precious metal catalyst”) elnevezéseket.

Elöállításuk hasonlóan a fémmentes $\mathrm{N}-\mathrm{C}$ katalizátorokhoz pirolízissel történhet (8. ábra); ekkor a prekurzor elegynek tartalmaznia kell valamilyen fémtartalmú kiindulási anyagot is. Fém prekurzorok lehetnek makrociklusos fémkomplexek, MOF-ok, vagy egyszerủen a beépíteni kívánt fém valamely alkalmas sója. ${ }^{11}$ Utóbbi esetben, ha a nitrogén és szén prekurzor 
is olcsó, a katalizátor előállítása valóban költséghatékony lehet. A prekurzor elegy pirolízisét követően sokszor kristályos fémfázisok (nanorészecskék) is maradnak az anyagban, melyeket savas kezeléssel szoktak eltávolítani. Ez kulcsfontosságú lépés, mivel a nanorészecskék jelenléte merőben eltérő katalitikus hatáshoz vezethet; sokszor a versengő hidrogénfejlesztést segítik a $\mathrm{CO}_{2}$ redukciójával szemben. ${ }^{70,71}$

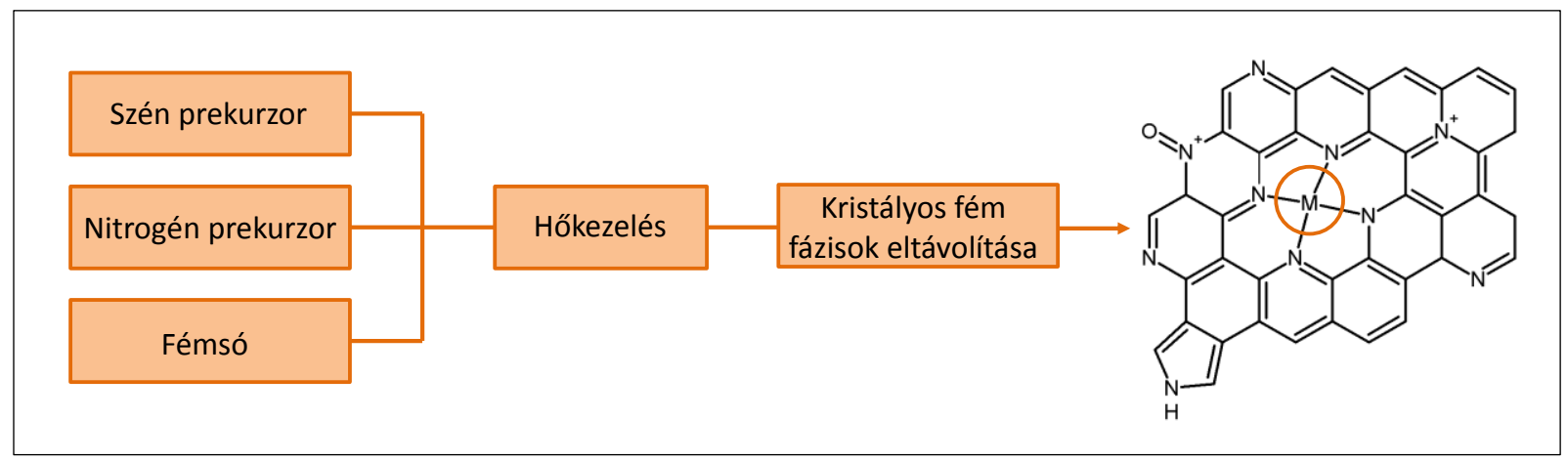

8. ábra: M-N-C katalizátorok előálításának folyamata.

Az $\mathrm{M}-\mathrm{N}-\mathrm{C}$ katalizátorok jellemzése és aktív helyeinek vizsgálata sokszor kihívást jelent éppen azok atomi jellege miatt. Aktív centrumként legtöbb esetben az $\mathrm{M}-\mathrm{N}_{\mathrm{x}}$ centrumokat valószínűsítik, amik a fémkomplexekben szintén megtalálható egységek. ${ }^{70,72}$ Fontos szerepet játszik továbbá a fémcentrum oxidációs állapota és a kapcsolódó $\mathrm{N}$-atomok kémiai környezete is a katalitikus aktivitás / szelektivitás meghatározásában. ${ }^{30,72}$ A fématomok aktivitásához ezen túl hozzájárulhatnak a szénváz egyéb $\mathrm{N}$-funkciói is, melyek hatását nehéz egymástól elkülöníteni. ${ }^{30}$ Több esetben is megmutatták azonban, hogy a megfelelö fémmentes $\mathrm{N}-\mathrm{C}$ katalizátor teljesítménye messze elmaradt az $\mathrm{M}-\mathrm{N}-\mathrm{C}$ katalizátorétól, így a fémcentrumok szerepe vitathatatlan..$^{71,73,74}$

Számos átmenetifém hatását (pl. $\mathrm{Fe}, \mathrm{Mn}, \mathrm{Cu}, \mathrm{Co}, \mathrm{Ni}$ ) vizsgálták már a $\mathrm{CO}_{2}$ redukciójában. ${ }^{28,70,71,75-77} \mathrm{~A}$ képződő termék legtöbb esetben a $\mathrm{CO}$, legaktívabbnak a Ni- és a Fe- centrumok bizonyultak. ${ }^{69,76,78}$ Míg a $\mathrm{Fe}$ általában a $\mathrm{CO}$ képződéséhez szükséges túlfeszültséget csökkentette nagyobb mértékben, a Ni jelenléte nagyobb CO szelektivitást és áramsürüséget biztosított, bár ehhez néhány száz mV-tal nagyobb túlfeszültség volt szükséges. ${ }^{30,69,76}$ Ez jó példa arra, hogy sokszor kompromisszumot kell kötni az aktivitás szelektivitás - energiahatékonyság hármasának tekintetében. Érdekes, hogy atomi katalizátorként azoknak a fémeknek $(\mathrm{Fe}, \mathrm{Ni})$ a legnagyobb $\mathrm{CO}_{2}$ a redukciós teljesítményük, 
melyek tömbfázisban a $\mathrm{H}_{2}$ fejlesztésben aktívak. $\mathrm{Fe}-\mathrm{N}-\mathrm{C}$ katalizátorokon továbbá $\mathrm{CO}$ képződése mellett nyomnyi mennyiségü metán fejlődését is megfigyelték. ${ }^{69,79}$ Kiemelkedő eredménynek számít, hogy egy $\mathrm{Ni}-\mathrm{N}-\mathrm{C}$ katalizátoron folyamatos áramlásos elektrolizáló cellában 90\% körüli Faraday hatásfok mellet $200 \mathrm{~mA} \mathrm{~cm}^{-2}$ parciális áramsürüséggel képződött a CO, stabilan 20 órán keresztül. ${ }^{73}$ Ez a teljesítmény megközelítette a legjobb CO-szelektív nemesfém katalizátorok hatékonyságát.

Az elmúlt mintegy tíz év során jelentős eredményeket sikerült elérni a heteroatomokkal adalékolt szén katalizátorok vizsgálatában, azonban számos lehetőség és kihívás áll előttünk a katalitikus teljesítményük és stabilitásuk javítása terén. Például a szénvázba beépíthető vizsgált fématomok köre még messze nem teljes, ráadásul többfémes rendszerek kialakításával még tovább bővülnek a lehetőségek. Új szintézismódszerek kidolgozása is szükséges, melyekkel szabályozott szerkezetü katalizátorokat lehet elóállítani a kívánt heteroatom konfigurációkkal és az aktív centrumok nagyobb koncentrációjával. Az aktív centrumok mellett a szénváz (morfológia, porozitás, stb.) is jelentős szerepet tölthet be a $\mathrm{CO}_{2}$ redukciós aktivitás meghatározásában, ez azonban még kísérletileg kevésbé vizsgált terület. Ahogy más katalizátorok esetén is, a kísérleti körülmények, mint az elektrolit koncentrációja és összetétele is jelentős hatással bírhat a folyamatban. ${ }^{30}$ Azonban például a fémek vizsgálata során kapott eredmények nem feltétlenül igazak más katalizátorcsoport esetén is, ezek vizsgálata elkerülhetetlen szénalapú katalizátorok esetén is.

\subsection{Nanoszerkezetủ elektrokatalizátorok a $\mathrm{CO}_{2}$ redukcióban}

Az elektrokatalizátorok fejlesztésének hatékony és gyakran alkalmazott módja a nanostruktúrák kialakítása. ${ }^{71,80-84}$ A nanoszerkezetü anyagok nagy fajlagos felülettel rendelkeznek, ennek következtében nagy arányban tartalmaznak éleket, sarkokat, alacsony koordinációjú helyeket a tömbfázisú anyaghoz képest, ami megváltoztathatja a köztitermékek kötési energiáját. Ez sokszor kedvezőbb $\mathrm{CO}_{2}$ redukciós tulajdonságokkal jár együtt. Nanoszerkezetủ anyagok esetén jelentős szerepet játszik a katalitikus aktivitás meghatározásában a részecskeméret, a morfológia és a pórusszerkezet, a kristályorientáció, az oxidációs állapot, hibahelyek jelenléte, valamint az esetleges hordozó hatása. 


\subsubsection{Morfológiai tényezők hatása a $\mathrm{CO}_{2}$ redukcióban}

A katalizátor morfológiája és pórusszerkezete különböző hatásokon keresztül befolyásolhatja a katalitikus aktivitást (9. ábra):

- Részecskeméret:

Fém nanorészecskék $\mathrm{CO}_{2}$ redukciós aktivitása általában függ a részecskemérettől. ${ }^{80-82}$ Általánosan elmondható, hogy a teljes redukciós aktivitás a részecskeméret csökkentésével nő, azonban ez a hatás különböző fémeknél eltérő módon jelentkezik a szelektivitás változásában. Réz nanorészecskék vizsgálata során azt tapasztalták, hogy $5 \mathrm{~nm}$ részecskeátmérő alatt a katalitikus aktivitás drasztikusan megnőtt a tömbfázisú katalizátorhoz képest. ${ }^{80} \mathrm{Az}$ aktivitásnövekedés a $\mathrm{CO}$ és $\mathrm{H}_{2}$ fejlödés elötérbe kerülésének volt köszönhető, míg a metán és az etilén képződése jelentősen visszaszorult a részecskeméret csökkentésével. Mindezek tükrében a szelektivitás részecskemérettől való függése felhasználható a termékarány szabályozására azonos anyagi minőségü katalizátorokon.

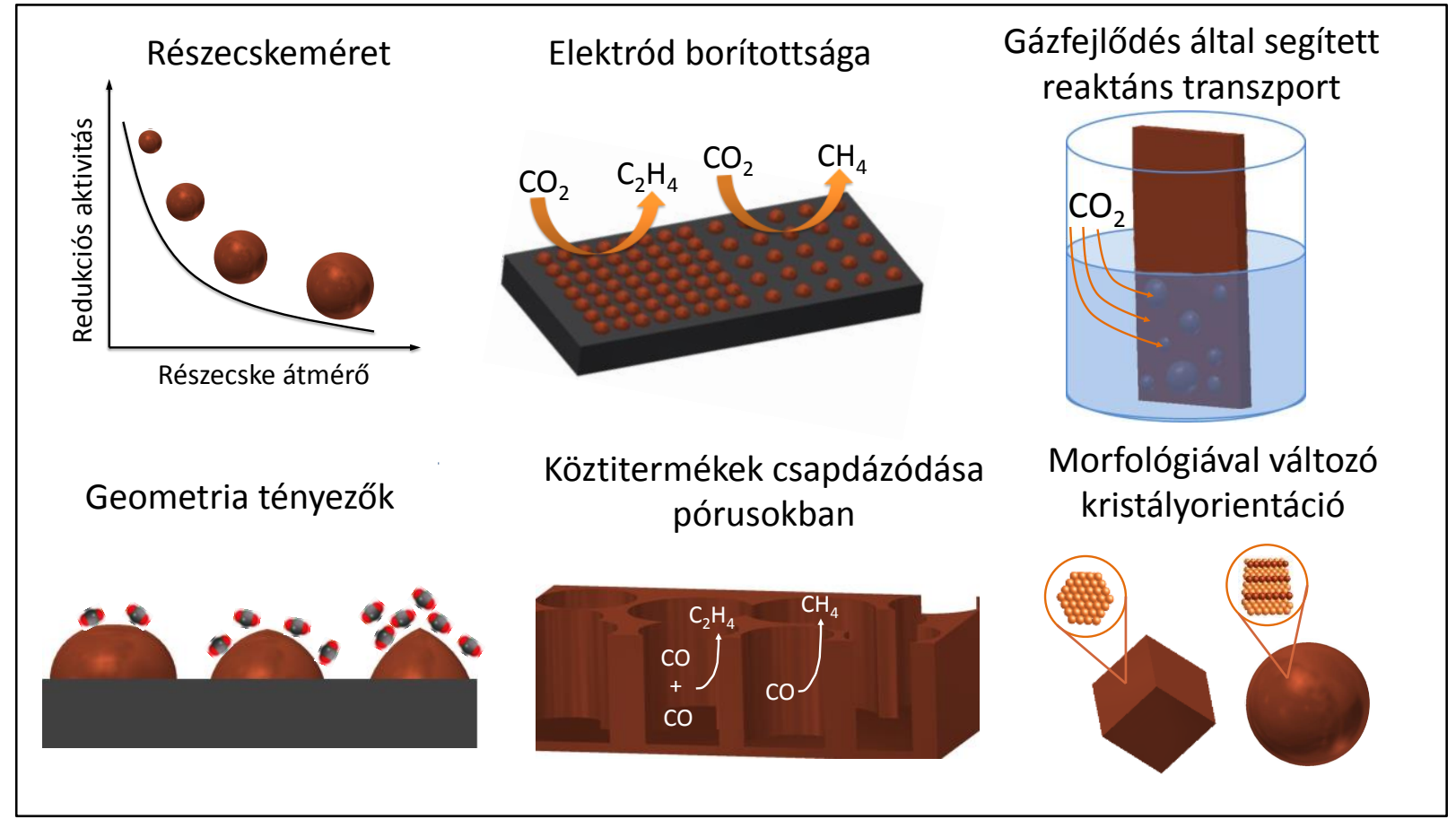

9. ábra: Morfológiai tényezők, melyek hatással vannak a nanoszerkezetű katalizátorok $\mathrm{CO}_{2}$ redukciós tulajdonságaira.

- Köztitermékek csapdázódása:

A pórusokon belül a redukciós termékek és / vagy köztitermékek csapdázódhatnak, tartózkodási idejük az aktív helyek közelében növekszik a sima felületü (nempórusos) katalizátorhoz képest. ${ }^{85,86}$ A csapdázódás elősegítheti további redukciójukat és a dimerizációt 
is. Részben ennek a hatásnak köszönhetően pórusos $\mathrm{Cu}$ elektródon a termékeloszlás eltolódott a többszénatomos termékek $\left(\mathrm{C}_{2} \mathrm{H}_{4}, \mathrm{C}_{2} \mathrm{H}_{6}\right)$ képződésének irányába a sima réz lemezhez képest. ${ }^{85}$

- Kristályorientáció változása:

Fém elektródok esetén a morfológia szabályozása érdekében alkalmazott módszerek befolyásolhatják a különböző orientációjú kristályok számát, elérhetőségét és az atomok koordinációs számát. Ezek a tényezők viszont jelentős hatással bírhatnak a katalitikus jellemzők meghatározásában, ${ }^{83}$ így közvetetten morfológiai tényezőknek tekinthetjük öket. Oxigén plazmával kialakított ezüst nanoszerkezetek kb. $300 \mathrm{mV}$-tal csökkentették a $\mathrm{CO}_{2}$, CO-dá való alakításához szükséges túlfeszültséget, 90\%-os szelektivitás mellett. A megnövekedett aktivitást a plazmakezelés során létrejött nagy számú hibahelynek és alacsony koordinációjú atomnak tulajdonították. ${ }^{25}$

- Geometriai tényezök:

Geometriai faktorok, mint a görbület mértéke is szerepet játszhatnak a redukciós tulajdonságok meghatározásában. Különböző alakú arany nanorészecskék (nanotü, nanopálcika, nanogömb) vizsgálata során megmutatták, hogy a nagyobb görbületü (kisebb átméröjü) felületen kedvezményezettebb a $\mathrm{CO}_{2}$ redukciója. ${ }^{87}$ Ezt azzal magyarázták, hogy nagyobb görbületủ felület közelében megnőtt az elektromos térerősség, ami az elektrolit kationjainak lokális koncentrációnövekedését okozta. Ez viszont együtt járt a $\mathrm{CO}_{2}$ lokális koncentrációjának növekedésével, ami miatt növekedett a $\mathrm{CO}_{2}$ redukciós aktivitás. A görbület mértéke továbbá a reaktánsok és köztitermékek kötési energiájának változásán keresztül is hatással lehet a szelektivitásra. ${ }^{88,89}$

\section{- Gázfejlődés hatása a reaktáns transzportra:}

Az elektród nanomorfológiája közvetetten befolyásolhatja a reaktáns fluxusát is az aktív helyek felé. Gáztermékek képződése során az elektród felületén növekvő, majd távozó buborékok konvekciót idéznek elö, ami segíti a $\mathrm{CO}_{2}$ transzportját és növeli a redukciós áramokat. Minél kisebbek a távozó buborékok (vagyis minél nagyobb gyakorisággal távoznak), annál erősebb ez a hatás. A távozó buborékok méretének meghatározásában jelentős szerepet játszik a katalitikus áramsürüség, az elektród hidrofil-hidrofób jellege és a morfológiája is. Arany katalizátor esetén a tüszerü morfológia elősegítette a kisebb buborékok távozását, ami növelte a maximális elérhető $\mathrm{CO}$ parciális áramsürüséget. ${ }^{90}$ 


\section{- Elektród borítottsága:}

A morfológia mellett az elektród borítottsága is befolyásolhatja a redukciós aktivitást. Különböző vastagságú arany inverz opál struktúrák vizsgálata során megfigyelték, hogy a hidrogénfejlődés sokkal érzékenyebb volt a rétegvastagság változtatására (nagyobb rétegvastagságnál csökkent), mint a $\mathrm{CO}_{2}$ redukciója. A hidrogénfejlődésre és a $\mathrm{CO}_{2}$ redukcióra vonatkozó eltérő anyagtranszport követelmények tehát lehetővé tették, hogy csupán a rétegvastagság módosításával szabályozzuk a $\mathrm{H}_{2} / \mathrm{CO}$ arányt. ${ }^{91} \mathrm{~A}$ borítottság továbbá a részecskék közötti távolság változásán keresztül is módosíthatja a termékeloszlást. Réz nanorészecskék esetén a részecskék közötti távolság csökkenésével nött az etilén szelektivitása, mivel a sürübben elhelyezkedő aktív centrumokon a keletkező CO readszorpciója elősegítette a dimerizálódást. ${ }^{92,93}$

Amint a fenti példákból látható, az elektród morfológiája több szempontból is lényeges hatással bírhat a $\mathrm{CO}_{2}$ redukciójában. Emiatt az is elengedhetetlen, hogy a reakció során esetlegesen bekövetkezö morfológiai változásokat is nyomon kövessük, hiszen ez együtt járhat a katalitikus aktivitás változásával. ${ }^{20}$ Réz nanorészecskék dinamikus morfológiai és kémiai változásait is megfigyelték $\mathrm{CO}_{2}$ redukció során. A réz nanokockák mérete csökkent, az élek és sarkok lekerekedtek, valamint pórusok alakultak ki a redukció során. Ennek következtében a katalizátorok $\mathrm{CO}_{2}$ redukciós aktivitása időben csökkent. ${ }^{94}$

\subsubsection{Nitrogénnel adalékolt szén elektródok morfológiájának szerepe elektrokémiai redukciós folyamatokban}

A fémekhez hasonlóan szén alapú katalizátoroknál is kulcsszerepet játszhat a morfológia és a porozitás, azonban ezeket a tényezőket sokszor figyelmen kívül hagyják az N-C elektródok vizsgálatánál. Nehézséget jelent, hogy ezeknek az anyagoknak a pórusszerkezete sokszor nem szabályozott, csupán a szintézis során véletlenszerủen alakul ki a prekurzorok minőségétöl és az elöállítási körülményektöl függően. Ebben az esetben ráadásul a morfológia nehezen kontrollálható és egy anyagon belül sem mindig egyforma, ami tovább nehezíti a szerkezethatás összefüggések megállapítását. N-C katalizátorok morfológiájának a szabályozására lehetöséget nyújthat a pirolízis során soft- és hard templátok alkalmazása, illetve utólagos kémiai kezelések $\left(\mathrm{NH}_{3}, \mathrm{KOH}, \mathrm{CO}_{2}\right)$ végrehajtása. ${ }^{95-98}$

Elektrokémiai oxigén redukciós reakcióban makro-, mezo- és mikropórusos $\mathrm{N}$-adalékolt szenek esetén is vizsgálták a pórusszerkezet hatását. A kisebb makropórusok $(150 \mathrm{~nm})$ és 
közepes mezopórusok $\left(22 \mathrm{~nm}\right.$ ) bizonyultak optimálisnak a folyamatban. ${ }^{95-97}$ Továbbá egy mezopórusos szénben utólagos ammóniás kezeléssel kialakított mikropórusok még tovább növelték az oxigén redukciós aktivitást a hierarchikus pórusszerkezet és a felületi csoportok együttes hatásának köszönhetően. ${ }^{99}$

A $\mathrm{CO}_{2}$ redukciót tekintve csupán néhány munkában vizsgálták érintőlegesen a morfológia és pórusszerkezet hatását szén elektródokon. Mikropórusos szén hordozó (aktivált szén rost) növelte a fém nanorészecskék $(\mathrm{Pd}, \mathrm{Ni}, \mathrm{Fe})$ redukciós aktivitását a mikropórusokat nem tartalmazó hordozóhoz képest. ${ }^{100}$ Ezt a mikropórusokban kedvezményezett $\mathrm{CO}_{2}$ adszorpcióval hozták összefüggésbe. Hengeres mezopórusokat tartalmazó N-C katalizátoron 77\%-os szelektivitással, egyedüli $\mathrm{CO}_{2}$ redukciós termékként etanol keletkezett. ${ }^{27} \mathrm{~A}$ különleges szelektivitást a pórusok felületén stabilizálódó $\mathrm{CO}^{*}$ köztitermékek dimerizációjával magyarázták. Az inverz morfológiájú katalizátoron egy versengő reakcióúton $\mathrm{CO}$ is képződött az etanol mellett, ami rámutatott a szénváz kulcsszerepére.

A hierarchikus pórusszerkezet nemcsak az oxigén, hanem a $\mathrm{CO}_{2}$ redukcióban is előnyösnek mutatkozott. Mezo-mikropórusos N- és S-adalékolt szén katalizátor hasonló szelektivitás mellett, azonban jelentősen nagyobb katalitikus áramsürüséggel redukálta a $\mathrm{CO}_{2}-$ ot a csupán mikropórusokat tartalmazó elektródhoz képest. ${ }^{101}$ Míg a makro- és a nagyobb mezopórusok a reaktáns transzportot segítik, a mikropórusok nagy fajlagos felületet eredményeznek, növelve ezzel az aktív centrumok elérhetöségét. Elméleti számítások arra is rámutattak, hogy az N-C katalizátorokban a görbület mértéke (pl. szén nanocső átméröje) is hatással van a köztitermékek adszorpciós energiájára, ami befolyásolhatja a szelektivitást és a szükséges túlfeszültséget. ${ }^{88}$

\subsection{Az elektrolit szerepe a $\mathrm{CO}_{2}$ redukcióban}

$\mathrm{Az}$ elektrokatalizátor mellett az elektrolit is meghatározó szerepet tölt be a $\mathrm{CO}_{2}$ redukciós folyamatban. Amellett, hogy megfelelő ionvezetést biztosít, ez szolgáltatja a reakcióhoz szükséges hidrogénionokat és a reaktáns is ezen keresztül (ebben oldva) jut el az elektród felületéhez. Az elektrolit továbbá részt vehet a köztitermékek stabilizálásában is vagy specifikus kölcsönhatások következtében új reakcióutakat nyithat meg. Az optimális elektrokatalizátor-elektrolit pár megválasztásával jelentős teljesítménynövekedést és / vagy a termékeloszlás változását lehet elérni elektrokémiai folyamatokban. Az elektrolit összetétele és 
koncentrációja többek között a pufferkapacitás és a töltésátviteli ellenállás változásán keresztül, valamint bizonyos ionok specifikus adszorpciójának hatása által befolyásolhatja a $\mathrm{CO}_{2}$ redukciós folyamatot. ${ }^{102-104}$

$\mathrm{A} \mathrm{CO}_{2}$ redukció során általában közel semleges $\mathrm{pH}$-jú vizes elektrolitokat alkalmaznak, leggyakrabban nátrium- vagy kálium-hidrogénkarbonát sót. Ennek előnye, hogy az oldott hidrogén-karbonát ionok további $\mathrm{CO}_{2}$ forrásként szolgálhatnak, ${ }^{65}$ illetve a $\mathrm{CO}_{2} / \mathrm{HCO}_{3}{ }^{-}$puffer a redukció során bekövetkező lokális $\mathrm{pH}$-változást tompítja. ${ }^{105} \mathrm{~A} \mathrm{CO}_{2}$ vízben való kis oldhatósága miatt $(\mathrm{kb} .33 \mathrm{mM})^{106}$ azonban már viszonylag kis áramsürüségeknél is transzport-limitálttá válhat a redukciós folyamat. ${ }^{107}$ Ennek kiküszöbölésére áramlásos elektrolizáló cellákban gázdiffúziós elektródokat használhatunk. ${ }^{9}, 108$

\subsubsection{A $\mathrm{CO}_{2}$ oldategyensúlya}

Az elektrolit összetételének és / vagy koncentrációjának a változtatása az oldott $\mathrm{CO}_{2}$ $\left(\mathrm{CO}_{2, \text { aq }}\right)$ koncentrációját is befolyásolja. $\mathrm{A} \mathrm{CO}_{2}$ vízben való oldódása során az alábbi egyensúlyokat kell figyelembe venni ${ }^{109}$ :

- $\quad \mathrm{A} \mathrm{CO}_{2}$ oldódási egyensúlya:

$$
\mathrm{CO}_{2, g} \leftrightharpoons \mathrm{CO}_{2, a q},
$$

ami függ a hőmérséklettöl, nyomástól és az ionerősségtöl.

- Az oldatban a különböző részecskék eloszlását meghatározó egyensúlyok:

$$
\begin{aligned}
\mathrm{CO}_{2, a q}+\mathrm{H}_{2} \mathrm{O} \leftrightharpoons \mathrm{H}_{2} \mathrm{CO}_{3, a q} & (5) \\
\mathrm{H}_{2} \mathrm{CO}_{3, a q} & \leftrightharpoons \mathrm{HCO}_{3, a q}^{-}+\mathrm{H}_{a q}^{+}, \mathrm{pK}_{1}=6,37\left(\mathrm{~T}=25^{\circ} \mathrm{C}\right) \\
\mathrm{HCO}_{3, a q}^{-} & \leftrightharpoons \mathrm{CO}_{3, a q}^{2-}+\mathrm{H}_{a q}^{+}, \mathrm{pK}_{2}=10,25\left(\mathrm{~T}=25^{\circ} \mathrm{C}\right)
\end{aligned}
$$

- A víz disszociációs egyensúlya:

$$
\mathrm{H}_{2} \mathrm{O} \leftrightharpoons H_{a q}^{+}+O H_{a q}^{-} \quad \mathrm{K}_{\mathrm{w}}=10^{-14}(\mathbf{8})
$$

Mivel a $\mathrm{H}_{2} \mathrm{CO}_{3, \mathrm{aq}}$ koncentrációja körülbelül egy ezred része a $\mathrm{CO}_{2 \text {,aq }}$ koncentrációjának ${ }^{109}$, ezért a továbbiakban nem teszek különbséget közöttünk, hanem együttesen a $\mathrm{CO}_{2, a q}$ * jelölést használom.

A fenti folyamatok nem függetlenek egymástól; a rendszernek két szabadsági foka van. Megválaszthatjuk szabadon például a pH-t és a teljes oldott széntartalmat, ekkor az egyes komponensek koncentrációja igazodik az egyensúlyi viszonyokhoz (10. ábra). 


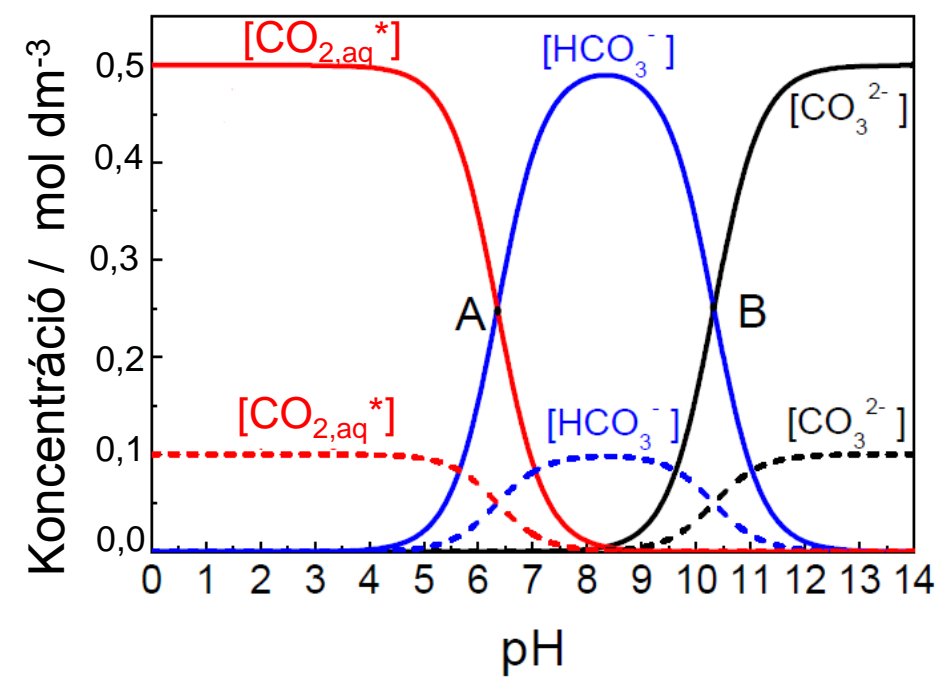

10. ábra: Az oldott $\mathrm{CO}_{2}$ eloszlási diagramja vizes közegben $0,5 \mathrm{M}$ és $0,1 \mathrm{M}$ teljes oldott széntartalom esetén. 109

Az eloszlási diagramon látható, hogyha az oldat $\mathrm{pH}$-ja kisebb, mint 5, a domináns oldott részecske a $\mathrm{CO}_{2, a q}{ }^{*}$, míg pH 7,5 és 9 között szinte kizárólag hidrogén-karbonát ion van jelen. A $\mathrm{CO}_{2}$ redukciós vizsgálatoknál általánosan alkalmazott elektrolit a $\mathrm{CO}_{2}$-dal telített $0,1 \mathrm{M}$ $\mathrm{KHCO}_{3}$-oldat, melynek $\mathrm{pH}$-ja 6,7. Ezen körülmények között az oldat összemérhető mennyiségben tartalmazza az oldott $\mathrm{CO}_{2, a q}{ }^{*}$-t és a $\mathrm{HCO}_{3}{ }^{-}$,aq ionokat.

\subsubsection{A reagáló részecske kérdése}

Központi kérdés, hogy $\mathrm{CO}_{2}$ redukció során az elektródon közvetlenül $\mathrm{a} \mathrm{CO}_{2 \text {,aq }}{ }^{*}-\mathrm{t}$ vagy a $\mathrm{HCO}_{3, \mathrm{aq}}{ }^{-}-\mathrm{t}$ redukáljuk-e. Ennek megválaszolása döntő lehet az elektrolit és a cellaelrendezés helyes kiválasztásában. Különböző fém elektródokon mindkét részecskét feltételezték reaktánsként. Több esetben azonban még ugyanazon fém vizsgálata esetén is ellentmondásos eredményre jutottak. Pb elektródon in situ infravörös spektroszkópiás mérések és Cu elektródon különböző pufferekben végzett on-line elektrokémiai tömegspektroszkópiás vizsgálatok által a hidrogén-karbonát iont azonosították reagáló részecskeként. ${ }^{110,111}$ Ezzel szemben kísérletekben, ahol a $\mathrm{CO}_{2, \mathrm{aq}}{ }^{*}$ és a $\mathrm{HCO}_{3, \mathrm{aq}}{ }^{-}$koncentrációját (vagy arányukat) változtatták valamilyen módon $\mathrm{Hg}, \mathrm{Pd}$ vagy $\mathrm{Cu}$ elektródokon, az oldott $\mathrm{CO}_{2}$-ot, vagy a hidrogén-karbonát ionból in situ képződő $\mathrm{CO}_{2}$-ot valószínűsítették reaktánsként. ${ }^{112-114}$ 


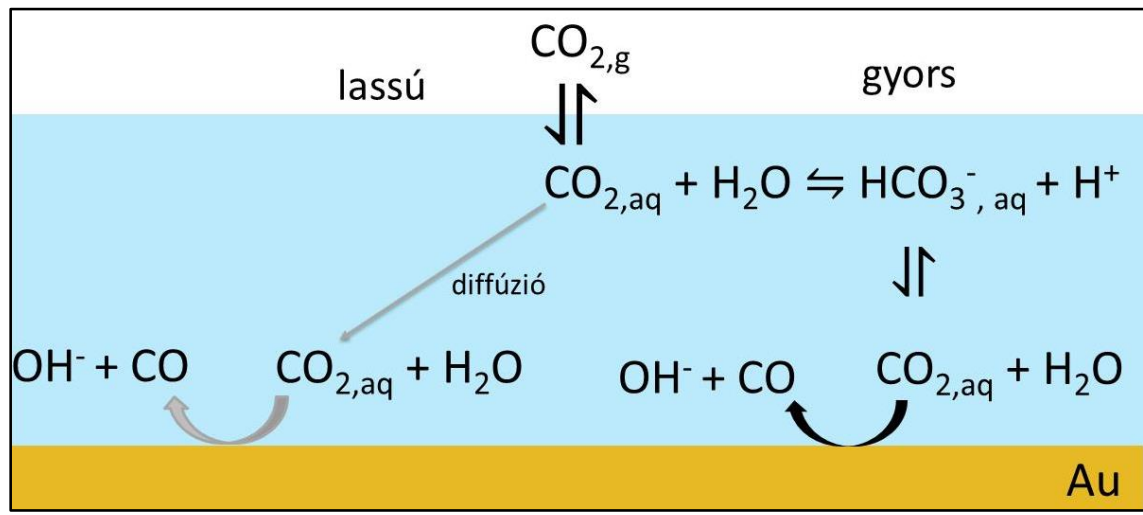

11. ábra: $\mathrm{A} \mathrm{CO}_{2}$ transzportja az elektródfelülethez diffúzióval és a hidrogén-karbonát ionok által közvetítve.

A közelmúltban in situ felület érzékenyített infravörös spektroszkópiás méréseket ${ }^{13} \mathrm{C}$ izotópjelzéssel és potenciálugrásos technikával kombinálva, $\mathrm{Au}$ és $\mathrm{Cu}$ elektródokon vizsgálták a fentebb említett kérdést. ${ }^{65,115}$ Megmutatták, hogy az elektród felületén közvetlenül reagáló részecske a $\mathrm{CO}_{2, \mathrm{aq}}{ }^{*}$, azonban a hidrogén-karbonát elektrolitnak kulcs szerepe van a nagy $\mathrm{CO}_{2}$ redukciós áramsürüségek elérésében (11. ábra). A hidrogén-karbonát elektrolit, amellett, hogy pH-puffer, biztosítja a $\mathrm{CO}_{2, a q}{ }^{*}$ nagy effektív koncentrációját is a reakciózónában a gyors $\mathrm{HCO}_{3, \mathrm{aq}}{ }^{-}+\mathrm{H}^{+} \leftrightharpoons \mathrm{CO}_{2, \mathrm{aq}}{ }^{*}+\mathrm{H}_{2} \mathrm{O}$ egyensúly által. Ez a javasolt mechanizmus összhangban van azzal a megfigyeléssel is, miszerint a $\mathrm{CO}_{2}$ redukció sebessége lényegesen nagyobb hidrogénkarbonát elektrolitban, mint azonos pH-jú egyéb pufferekben. ${ }^{116}$ 


\section{Motiváció és célkitűzések}

A Szegedi Tudományegyetem Fizikai Kémiai és Anyagtudományi Tanszékén müködő Fotoelektrokémiai Kutatócsoport egyik fő kutatási iránya a szén-dioxid elektrokémiai és fotoelektrokémiai redukciója tüzelőanyagokká és kémiai nyersanyagokká. Napjainkban ez egy igen széles körben és intenzíven vizsgált terület, hiszen hozzásegítheti társadalmunkat egy fenntartható energiagazdaság megteremtéséhez.

A $\mathrm{CO}_{2}$ redukció gyakorlati megvalósításának kulcsa hatékony elektrokatalizátorok fejlesztése. Ezt célozta doktori munkám is az újgenerációs katalizátor csoport, a (fémmel-) és nitrogénnel adalékolt szenek ((M)-N-C) elektrokatalitikus tulajdonságainak vizsgálatával. Tekintettel arra, hogy mindössze tizenöt év telt el az első $\mathrm{N}-\mathrm{C}$ katalizátort $\mathrm{CO}_{2}$ redukcióban vizsgáló tudományos publikáció megjelenése óta, számos nyitott kérdés áll fent a témában. Doktori munkám során célunk volt vizsgálni az $(\mathrm{M})-\mathrm{N}-\mathrm{C}$ katalizátorok szén-dioxid redukciós teljesítményét meghatározó különböző tényezőket, mind a katalizátor, mind pedig a folyamat mechanizmusának szempontjából (12. ábra).

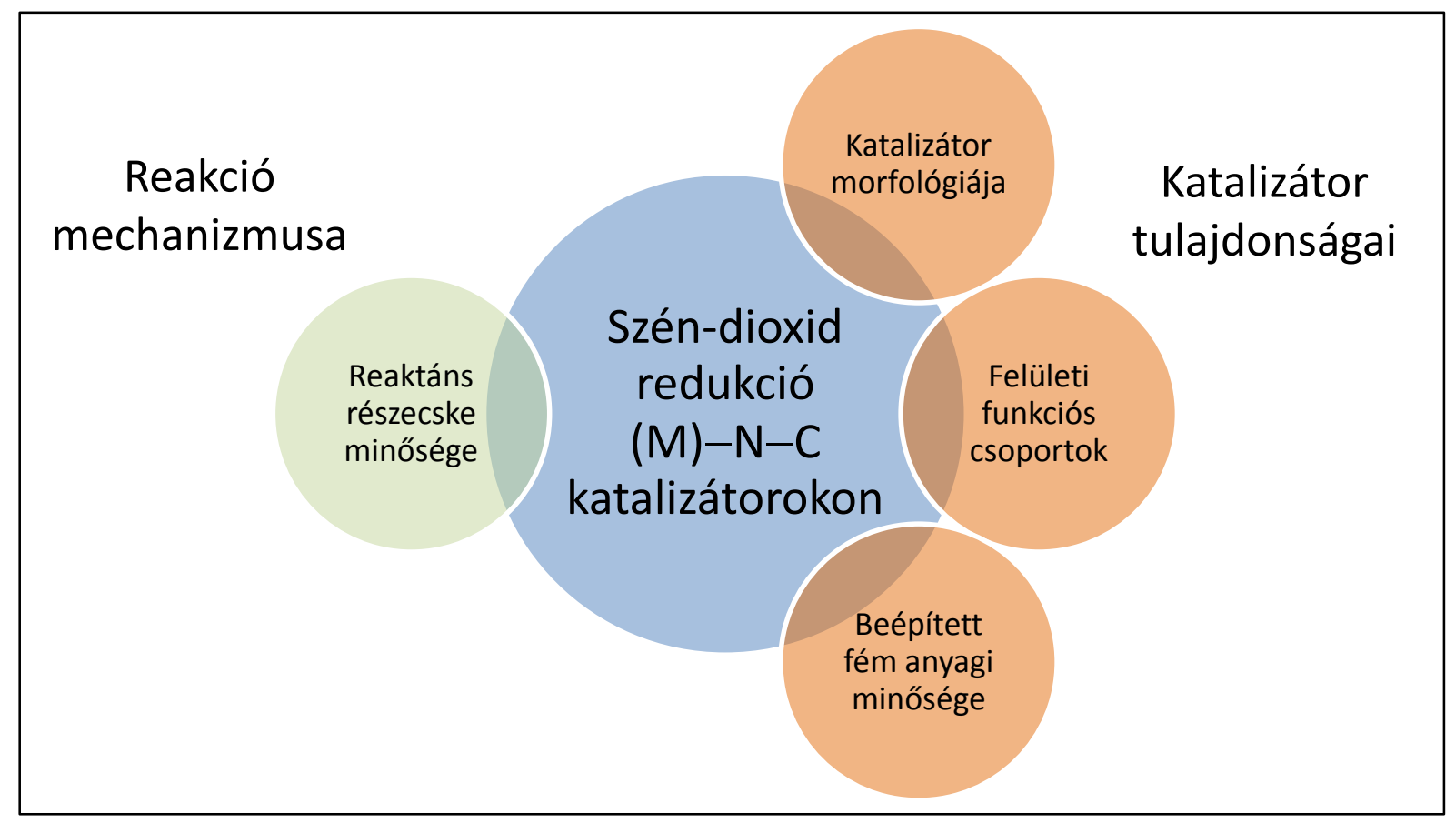

12. ábra: A doktori munkám célkitüzései.

Először arra kerestük a választ, hogy vajon mi a reaktáns részecske a szén-dioxid redukciójában az $\mathbf{N}-\mathbf{C}$ katalizátorok felületén. Régóta vitatott kérdés különböző fém 
katalizátorok esetén, hogy közvetlenül az oldott szén-dioxid molekula vagy a hidrogénkarbonátion alakul-e át a redukciós folyamatban. Célunk volt izotópjelzéses kísérletek segítségével választ adni erre a kérdésre, hiszen ennek ismerete segíthet az elektrolit és a reakciókörülmények helyes megválasztásában.

Következö lépésként az N-C katalizátorok morfológiájának hatását vizsgáltuk. Célunk volt olyan katalizátorokat elöállítani, melyek a morfológián kívül minden fizikai-kémiai jellemzöiben közel megegyeztek. Vizsgálni kívántuk, hogyan változik a $\mathrm{CO}_{2}$ redukciós aktivitás az elektródok porozitásának változtatásával, és hogy mi állhat a morfológiától függő redukciós viselkedés hátterében.

A pórusméret hatásának vizsgálatát követően további célunk volt az N-C elektródok felületi funkciós csoportjainak a szerepét is vizsgálni. Ennek érdekében adott pórusméret mellett különböző prekurzorokból állítottuk elő a katalizátorokat, miáltal a kémiai összetételük változott. Ezen túl különböző, a morfológia szabályozása érdekében gyakran alkalmazott utólagos kémiai kezelések hatását is vizsgálni kívántuk a redukcióban. A röntgen-fotoelektron spektroszkópiával meghatározott felületi összetétel és a redukciós aktivitás közötti összefüggést vizsgáltuk.

Végül $\mathbf{M}-\mathbf{N}-\mathbf{C}$ katalizátorokban a fématomok anyagi minőségének a $\mathrm{CO}_{2}$ redukcióra és hidrogénfejlesztésre gyakorolt hatásának a tanulmányozását túztük ki célul. Ismert, hogy jelentős aktivitásnövekedést lehet elérni a $\mathrm{CO}_{2}$ redukcióban, ha bizonyos fématomokat építünk be az $\mathrm{N}-\mathrm{C}$ vázba. Olyan fémtartalmú katalizátorokat kívántunk vizsgálni, melyeket ezt megelőzően a $\mathrm{CO}_{2}$ redukcióban nem, vagy kevéssé vizsgáltak. 


\section{Felhasznált vegyszerek és alkalmazott kísérleti módszerek}

\subsection{Vegyszerek}

Katalizátor szintézis és elektród készítés:

- Pirrol ( $\mathrm{C}_{4} \mathrm{H}_{5} ; 98 \%$; Sigma-Aldrich; 67,09 $\left.\mathrm{g} \mathrm{mol}^{-1}\right)$

- Anilin $\left(\mathrm{C}_{6} \mathrm{H}_{5} \mathrm{NH}_{2} ;>99,5 \%\right.$; Sigma-Aldrich; 93,13 $\left.\mathrm{g} \mathrm{mol}^{-1}\right)$;

- o-fenilén-diamin $\left(\mathrm{C}_{6} \mathrm{H}_{8} \mathrm{~N}_{2}\right.$; VWR; 108,14 $\left.\mathrm{g} \mathrm{mol}^{-1}\right)$

- Fitinsav $\left(\mathrm{C}_{6} \mathrm{H}_{18} \mathrm{O}_{24} \mathrm{P}_{6} ; 50 \mathrm{w} \%\right.$; Sigma-Aldrich; 660,04 $\left.\mathrm{g} \mathrm{mol}^{-1}\right)$

- Ammónium-peroxo-diszulfát $\left(\left(\mathrm{NH}_{4}\right)_{2} \mathrm{~S}_{2} \mathrm{O}_{8} ; 98 \%\right.$, Acros Organics; 228, $\left.18 \mathrm{~g} \mathrm{~mol}^{-1}\right)$

- Kálium-hidroxid (KOH; 85,8\%; Fluka; 56,11 $\mathrm{g} \mathrm{mol}^{-1}$ )

- 4-aminoantipirin $\left(\mathrm{C}_{11} \mathrm{H}_{13} \mathrm{~N}_{3} \mathrm{O}\right.$; Sigma-Aldrich; 203,24 $\left.\mathrm{g} \mathrm{mol}^{-1}\right)$

- Réz-nitrát trihidrát $\left(\mathrm{Cu}\left(\mathrm{NO}_{3}\right)_{2} \cdot 3 \mathrm{H}_{2} \mathrm{O}\right.$; > 99\%; Sigma-Aldrich; 241,60 g mol$\left.{ }^{-1}\right)$

- Prazeodímium-nitrát hexahidrát $\left(\operatorname{Pr}\left(\mathrm{NO}_{3}\right)_{3} \cdot 6 \mathrm{H}_{2} \mathrm{O}\right.$; 99,9\%; Sigma-Aldrich; 435,01 g $\left.\mathrm{mol}^{-1}\right)$

- Cérium-nitrát hexahidrát $\left(\mathrm{Ce}\left(\mathrm{NO}_{3}\right)_{3} \cdot 6 \mathrm{H}_{2} \mathrm{O}\right.$; 99\%; Sigma-Aldrich; 434,22 $\left.\mathrm{g} \mathrm{mol}^{-1}\right)$

- Ammónium-heptamolibdát tetrahidrát $\left(\left(\mathrm{NH}_{4}\right)_{6} \mathrm{Mo}_{7} \mathrm{O}_{24} \cdot 4 \mathrm{H}_{2} \mathrm{O} ; 99,98 \%\right.$; SigmaAldrich ; 1235,86 $\mathrm{g} \mathrm{mol}^{-1}$ )

- CAB-O-SIL LM150 szilika ( $\mathrm{SiO}_{2}$; CABOT; 60,08 $\left.\mathrm{g} \mathrm{mol}^{-1}\right)$

- LEVASIL-CT3 szilika kolloid ( $\mathrm{SiO}_{2} ; 50$ w\%; AkzoNobel; 60,08 $\mathrm{g} \mathrm{mol}^{-1}$ )

- LUDOX-TM50 szilika kolloid ( $\mathrm{SiO}_{2} ; 50 \mathrm{w} \%$; Aldrich; 60,08 $\left.\mathrm{g} \mathrm{mol}^{-1}\right)$

- LUDOX HS40 szilika kolloid ( $\mathrm{SiO}_{2} ; 40$ w\%; Aldrich; 60,08 $\mathrm{g} \mathrm{mol}^{-1}$ )

- Hidrogén-klorid oldat ( $\mathrm{HCl} ; 37$ w\%; VWR; 36,46 $\mathrm{g} \mathrm{mol}^{-1}$ )

- Hidrogén-fluorid oldat (HF; $40 \mathrm{w} \%$; VWR; 20,01 $\mathrm{g} \mathrm{mol}^{-1}$ )

- Nafion-diszperzió (10\%, FuelCell Store)

- Etanol $\left(\mathrm{C}_{2} \mathrm{H}_{5} \mathrm{OH}\right.$; 99\%; VWR; 46,07 $\left.\mathrm{g} \mathrm{mol}^{-1}\right)$

- Aceton $\left(\mathrm{C}_{3} \mathrm{H}_{6} \mathrm{O} ; 100 \%\right.$; VWR; 58,08 $\left.\mathrm{g} \mathrm{mol}^{-1}\right)$

- Alumínium - oxid polírozó por $\left(\mathrm{Al}_{2} \mathrm{O}_{3}\right.$, MicroPolish Alumina; Buehler; 0,5 $\left.\mu \mathrm{m}\right)$

- szintetikus levegő $\left(20,5 \% \mathrm{O}_{2}, 79,5 \% \mathrm{~N}_{2}\right.$; Messer $)$

- nitrogén gáz $\left(\mathrm{N}_{2} ; 99,995 \% ; 28,02 \mathrm{~g} \mathrm{~mol}^{-1}\right.$; Messer $)$

- ammónia gáz $\left(\mathrm{NH}_{3} ; 17,03 \mathrm{~g} \mathrm{~mol}^{-1}\right.$; Linde) 
Elektrokémiai vizsgálatok:

- Kálium-hidrogén-karbonát $\left(\mathrm{KHCO}_{3}\right.$; > $99 \%$; VWR; 100,11 $\left.\mathrm{g} \mathrm{mol}^{-1}\right)$

- Kálium-szulfát $\left(\mathrm{K}_{2} \mathrm{SO}_{4} ;>98 \%\right.$; Reanal; 174,26 $\left.\mathrm{g} \mathrm{mol}^{-1}\right)$

- Nátrium-szulfát ( $\mathrm{Na}_{2} \mathrm{SO}_{4}$; vízmentes, 99\%; Alfa Aesar; 142,04 g mol-1)

- Szén-dioxid gáz $\left(\mathrm{CO}_{2} ; 99.995 \%\right.$; 44,01 $\mathrm{g} \mathrm{mol}^{-1}$; Messer $)$

- Argon gáz (Ar; 99,999\%; 39,95 $\mathrm{g} \mathrm{mol}^{-1}$; Messer)

$\underline{\text { Redukciós termékek analízise: }}$

- Deutérium-oxid ( $\mathrm{D}_{2} \mathrm{O} ; 99,9$ atom\% D; Sigma Aldrich; 20,03 $\mathrm{g} \mathrm{mol}^{-1}$ )

- Fenol $\left(\mathrm{C}_{6} \mathrm{H}_{6} \mathrm{O} ; 99,5 \%\right.$; Sigma Aldrich; 94,11 $\left.\mathrm{g} \mathrm{mol}^{-1}\right)$

- Dimetil-szulfoxid $\left(\mathrm{C}_{2} \mathrm{H}_{6} \mathrm{SO}\right.$; >99\%; Alfa Aesar, 78,13 $\left.\mathrm{g} \mathrm{mol}^{-1}\right)$

Izotópjelzéses kísérletek:

- ${ }^{13} \mathrm{C}$ jelzett nátrium-hidrogénkarbonát $\left(\mathrm{NaH}^{13} \mathrm{CO}_{3} ; 98\right.$ atom $\%{ }^{13} \mathrm{C} ;<2 \%{ }^{18} \mathrm{O}$; Sigma Aldrich; 85,01 $\mathrm{g} \mathrm{mol}^{-1}$ )

- ${ }^{13} \mathrm{C}$ jelzett szén-dioxid $\left({ }^{13} \mathrm{CO}_{2} ; 99\right.$ atom\% ${ }^{13} \mathrm{C}$; Sigma Aldrich; 45,01 $\left.\mathrm{g} \mathrm{mol}^{-1}\right)$

A pirrol és anilin monomereket felhasználás elött desztillációval tisztítottuk. A többi vegyszert tisztítás nélkül használtuk fel. A vizes oldatok készítéséhez ioncserélt vizet használtunk (Millipore Direct Q3-UV), melynek fajlagos ellenállása 18,2 M $\mathrm{cm}$.

\subsection{Kísérleti módszerek}

\subsubsection{A katalizátorok szintézise}

A vizsgált elektrokatalizátorokat a megfelelő szén-, nitrogén-, és fém prekurzorokból magas hőmérsékletü pirolízissel állítottuk elő.

Az izotópjelzéses kísérletek során használt katalizátor szintézise:

Az izotópjelzéses kísérletek során alkalmazott HPG-PPy katalizátor szintézise során nitrogén- és szén prekurzorként egy polipirrol hidrogélt használtunk. A szintézis során $13 \mathrm{~mL}$ 2,8 $\mathrm{M}$ frissen desztillált pirrolt és $0,58 \mathrm{M}$ fitinsavat tartalmazó vizes oldathoz $10 \mathrm{~mL} 1,5 \mathrm{M}$ ammónium-peroxo-diszulfát oldatot csepegtettünk $0{ }^{\circ} \mathrm{C}$-on (jeges vizes fürdő), folyamatos kevertetés közben. A polimerizációs folyamat az oxidálószer hozzáadása után azonnal megkezdődött, amit egy sötétkék színü hidrogél megjelenése jelzett. Ezt követően $50 \mathrm{~mL}$ ioncserélt vizet adtunk a polimerizációs elegyhez, melyet egy órán keresztül tovább 
kevertettünk a jeges vizes fürdőben, majd 24 órára hütőbe helyeztük. A kapott polimert liofilizálással szárítottuk. Szárítás után a polipirrol aerogélt csőkemencében, $\mathrm{N}_{2}$ áramban karbonizáltuk ( $900{ }^{\circ} \mathrm{C}, 2$ óra, $110 \mathrm{~cm}^{3} \mathrm{~min}^{-1}$ áramlási sebesség). A fütési program a következő volt: RT $-2{ }^{\circ} \mathrm{C} \min ^{-1}-600{ }^{\circ} \mathrm{C}(0 \mathrm{~min})-5{ }^{\circ} \mathrm{C} \min ^{-1}-900^{\circ} \mathrm{C}(2 \mathrm{~h})$. A pirolízis során kapott szenet $7 \mathrm{M} \mathrm{KOH}$ oldatban $(\mathrm{m}(\mathrm{KOH}) / \mathrm{m}(\mathrm{C})=3)$ szuszpendáltuk, egy órán keresztül kevertettük és $60{ }^{\circ} \mathrm{C}$-on vákuumban szárítottuk. Végül a mintát $800^{\circ} \mathrm{C}$-on egy órán keresztül $\mathrm{N}_{2}$ áramban hőkezeltük $\left(110 \mathrm{~cm}^{3} \mathrm{~min}^{-1}\right.$ áramlási sebesség, cső átmérője: $3,18 \mathrm{~cm}$; hossza: $102 \mathrm{~cm} ; 5^{\circ} \mathrm{C} \mathrm{min}^{-}$ ${ }^{1}$ felfütési sebesség). Az így kapott HPG-PPy katalizátort a szennyezések eltávolítása céljából ultratiszta vízzel mostuk közel semleges $\mathrm{pH}(<8)$ eléréséig.

\section{A pórusos szén katalizátorok szintézise:}

A pórusos szén katalizátorokat polipirrol (PPy), polianilin (PANI) és poli(o-feniléndiamin) (PoPD) polimerekből hard-templát módszerrel állítottuk elő. A pórusok kialakítása céljából templátként monodiszperz szilika nanorészecskéket használtunk. A szintézis során 0,58 M monomert és $0,72 \mathrm{M} \mathrm{HCl-t}$ tartalmazó oldatban $0,19 \mathrm{~g} \mathrm{~cm}^{-3}$ szilika nanorészecskét diszpergáltunk folyamatos intenzív keveréssel 15 percen keresztül, hogy a monomer molekulák a szilika részecskék felületén adszorbeálódjanak. Ezt követően 2,7 M ammónium-peroxodiszulfátot (APS) és 1,0 M HCl-t tartalmazó vizes oldatot csepegtettünk a monomert tartalmazó szuszpenzióhoz (n (monomer) / n (APS) = 0,8) jeges vizes fürdőben való folyamatos kevertetés mellett. A polimerizációs folyamat megindulását a polimerizációs elegy színváltozása jelezte (PANI: zöld, PoPD: vörös, PPy: sötétkék/fekete). Az oxidálószer hozzáadása után az elegyek kevertetését 24 órán keresztül folytattuk a jeges vizes fürdőben. A kapott polimer / $\mathrm{SiO}_{2}$ kompozitokat liofilizálással szárítottuk és $900^{\circ} \mathrm{C}$-on $\mathrm{N}_{2}$ áramban $\left(110 \mathrm{~cm}^{3} \mathrm{~min}^{-1}\right)$ karbonizáltuk. A fütési program a következő volt: $\mathrm{RT}-5^{\circ} \mathrm{C} \min ^{-1}-180^{\circ} \mathrm{C}(1 \mathrm{~h})-5{ }^{\circ} \mathrm{C} \min ^{-1}-900^{\circ} \mathrm{C}(2 \mathrm{~h})$. Az N-C / szilika kompozitokból a szilika nanorészecskéket feleslegben alkalmazott 15 w\% HFoldattal szobahömérsékleten oldottuk ki. Végül a pórusos N-C katalizátorokat ioncserélt vízzel való alapos mosással és vákuumszüréssel tisztítottuk közel semleges $(>5) \mathrm{pH}$ eléréséig.

A morfológia hatásának vizsgálatához a katalizátor mintákat PoPD prekurzor polimerből három különböző átméröjü (13 nm, $27 \mathrm{~nm}$ és $90 \mathrm{~nm}$ nominális átmérö) szilika nanorészecske (13. ábra) alkalmazásával állítottuk elő. Továbbá egy nem pórusos mintát is készítettünk szilika templát alkalmazása nélkül. 


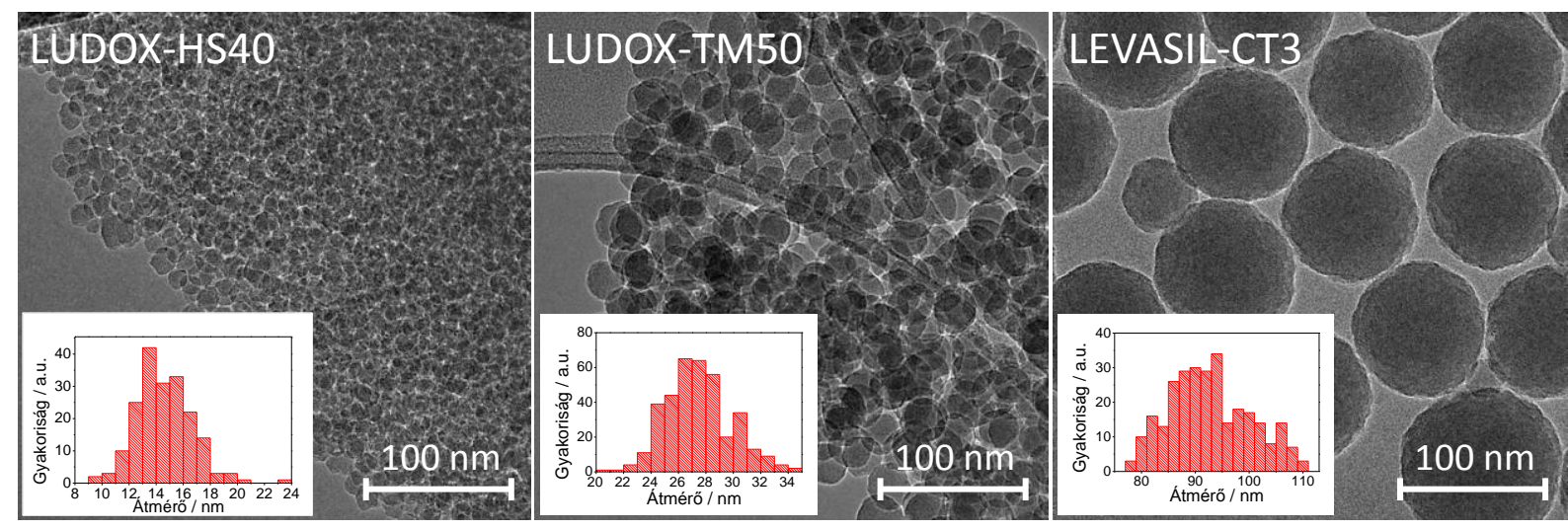

13. ábra: A pórusos N-C katalizátorok szintéziséhez használt szilika nanorészecskék TEM felvételei és a részecskeméret- eloszlás diagramok.

A felületi csoportok hatásának felderítését célzó munka során öt különböző prekurzorból állítottunk elő N-C katalizátorokat $27 \mathrm{~nm}$ átmérőjű szilika templát részecskék jelenlétében. A prekurzor polimerek a PANI, a PPy, a PoPD valamint a PANI és PoPD 30 : 70 és 70 : 30 arányú keverékei voltak. A keverék prekurzorok előállításánál a liofilizálást követően a PANI / $\mathrm{SiO}_{2}$ és a PoPD / $\mathrm{SiO}_{2}$ kompozitokat dörzsmozsárban porítottuk és megfelelő tömegarányban összekevertük.

A PoPD-C-27 minta esetén vizsgáltuk utólagos kémiai kezelések hatását is a $\mathrm{CO}_{2}$ redukcióban. A KOH-os kezelés (PoPD-C-27-KOH) során a HPG-PPy szintézisénél ismertetett eljárást alkalmaztuk. Az ammóniás kezelés során (PoPD-C-27-NH 3 ) a PoPD-C-27 katalizátort csőkemencében ammónia gáz áramában $\left(70 \mathrm{~cm}^{3} \mathrm{~min}^{-1}\right.$; cső átmérője: $2,37 \mathrm{~cm}$, hossza: $\left.70 \mathrm{~cm}\right)$ egy órán keresztül $900{ }^{\circ} \mathrm{C}$-on hőkezeltük. A felfütési és kihülési lépések $\mathrm{N}_{2}$ áramban $\left(70 \mathrm{~cm}^{3}\right.$ $\min ^{-1}$ ) történtek. Ezt követően ioncserélt vízzel alaposan mostuk a mintát.

$\underline{\text { A fém- és nitrogén adalékolt szén katalizátorok szintézise: }}$

A fém- és nitrogén adalékolt szén elektródokat $(\mathrm{Cu}-\mathrm{N}-\mathrm{C} ; \mathrm{Mo}-\mathrm{N}-\mathrm{C} ; \mathrm{Ce}-\mathrm{N}-\mathrm{C}$; Pr-N-C) Prof. Plamen Atanassov kutatócsoportjában (University of New Mexico; Center for Micro-Engineered Materials) hard templát módszerrel állították elő. A szén- és nitrogén prekurzor 4-aminoantipirin volt, fém prekurzorokként réz-nitrátot, prazeodímium-nitrátot, cérium-nitrátot és ammónium-heptamolibdátot használtak. A szintézis során első lépésként 10 g aminoantipirinből, $5 \mathrm{~g}$ szilika nanorészecskéből $\left(\sim 150 \mathrm{~m}^{2} \mathrm{~g}^{-1}\right)$ és a megfelelő fémsóból szuszpenziót készítettek. A fémsók tömegei a következők voltak: 1,5 $\mathrm{g} \mathrm{Cu}\left(\mathrm{NO}_{3}\right)_{2} \cdot 3 \mathrm{H}_{2} \mathrm{O} ; 1,75$ $\mathrm{g} \operatorname{Pr}\left(\mathrm{NO}_{3}\right)_{3} \cdot 6 \mathrm{H}_{2} \mathrm{O} ; 1,6 \mathrm{~g} \mathrm{Ce}\left(\mathrm{NO}_{3}\right)_{3} \cdot 6 \mathrm{H}_{2} \mathrm{O}$ és $0,75 \mathrm{~g}\left(\mathrm{NH}_{4}\right)_{6} \mathrm{Mo}_{7} \mathrm{O}_{24} \cdot 4 \mathrm{H}_{2} \mathrm{O}$. A szuszpenzió víztartalmát $85^{\circ} \mathrm{C}$-on $(8 \mathrm{~h})$ elpárologtatták, a porkeveréket dörzsmozsárban porították és 945 
${ }^{\circ} \mathrm{C}$-on $\mathrm{N}_{2}$ áramban karbonizálták (45 min, $100 \mathrm{~cm}^{3} \mathrm{~min}^{-1}, 10{ }^{\circ} \mathrm{C} \mathrm{min}^{-1}$ felfütési sebesség). A pirolízis során kapott szénből a szilikát feleslegben alkalmazott 40 w\%-os HF-oldattal oldották ki, majd a szeneket ioncserélt vízzel semleges $\mathrm{pH}$ eléréséig mosták. Levegőn történő száritást követően $\left(85^{\circ} \mathrm{C} ; 8 \mathrm{~h}\right)$ egy újabb hökezelésnek vetették alá a katalizátor mintákat $10 \%$ ammóniát tartalmazó nitrogén áramban (15 $\mathrm{min} ; 100 \mathrm{~cm}^{3} \mathrm{~min}^{-1} ; 25{ }^{\circ} \mathrm{C} \min ^{-1}$ felfütési sebesség). A fémmentes $\mathrm{N}-\mathrm{C}$ katalizátort ugyanezzel a módszerrel állították elő, fém prekurzor alkalmazása nélkül.

\subsubsection{Elektródok készítése}

$\mathrm{Az}$ elektrokémiai vizsgálatokhoz az elöállított katalizátorokból elektródokat készítettünk. Ehhez üvegszén hordozóra porlasztással vittük fel a kívánt anyagot. A porlasztáshoz a katalizátort $5 \mathrm{mg} \mathrm{mL}^{-1}$ koncentrációban $0,1 \mathrm{w} \%$ Nafion ionomert tartalmazó etanol-víz elegyben $(50 \mathrm{~V} / \mathrm{V} \%)$ diszpergáltuk. A porlasztást egy egyedileg készített automata porlasztva fújó berendezéssel végeztük (14. ábra). A hordozó üvegszén elektródokat a katalizátorok felvitelét megelőzően $0,05 \mu \mathrm{m}$ részecskeméretü alumínium-oxid porral políroztuk, majd 3-3 percen keresztül acetonban, etanolban és ioncserélt vízben való ultrahangos rázatással tisztítottuk. Az üvegszén lemezeket a porlasztáshoz $110{ }^{\circ} \mathrm{C}$-ra fütöttük, elösegítve ezzel az oldószer elpárolgását. A katalizátor rétegek pontos tömegét minden esetben egy Mettler Toledo XPE-26 típusú analitikai mikromérleggel ellenőriztük.

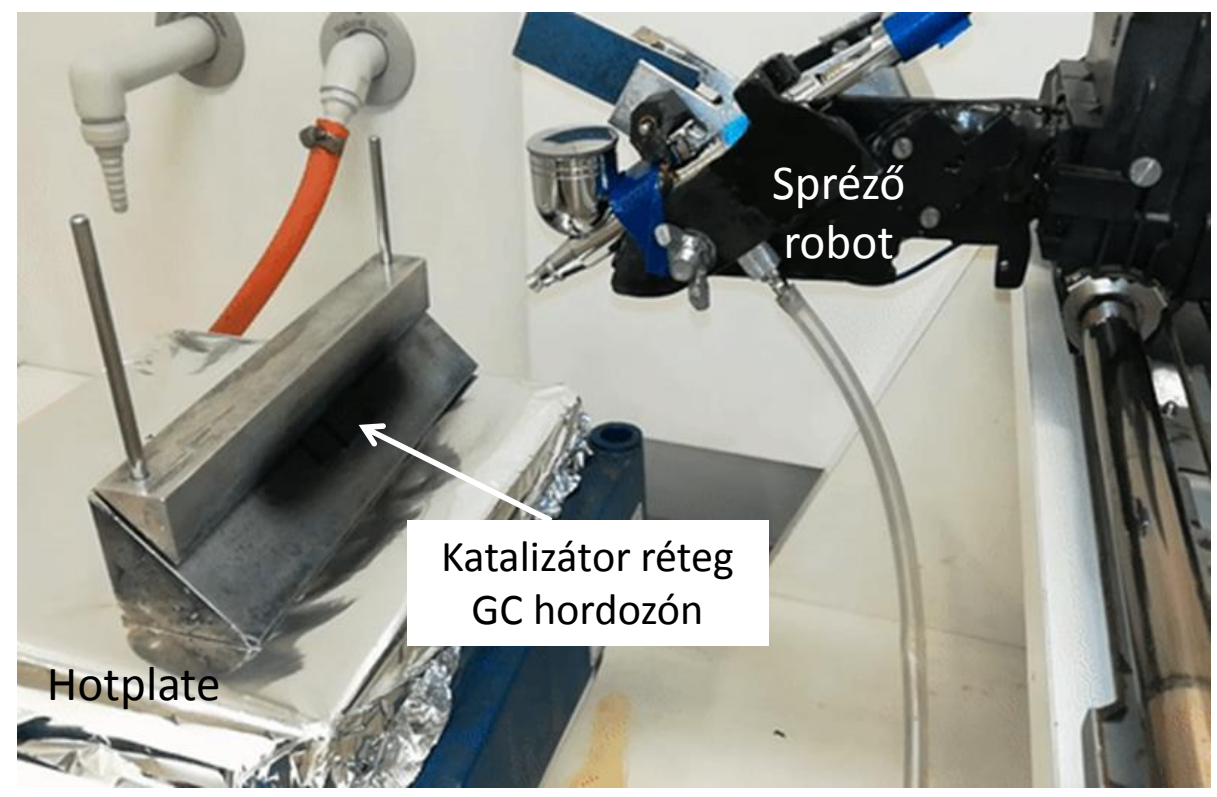

14. ábra: A katalizátor rétegek készítéséhez használt porlasztva fújó készülék. 


\subsubsection{Anyagvizsgáló módszerek}

\section{Raman-spektroszkópia:}

Raman-spektroszkópiával vizsgáltuk az N-C katalizátorok szén szerkezetét. A szenek Raman-spektrumán megjelenő G-sáv $\left(\sim 1580 \quad \mathrm{~cm}^{-1}\right)$, az $\mathrm{sp}^{2}$ hibrid állapotú szenek nyújtórezgéséhez rendelhető, míg a D-sáv $\left(\sim 1350 \mathrm{~cm}^{-1}\right)$ hibahelyek jelenlétére utal a szénvázban. ${ }^{117}$ A két sáv intenzitásaránya $\left(\mathrm{I}_{\mathrm{D}} / \mathrm{I}_{\mathrm{G}}\right)$ információt nyújt a grafitosság fokáról és a hibahelyek mennyiségéröl. A Raman-spektrumokat Senterra II Compact Raman mikorszkóppal (Bruker) vettük fel $532 \mathrm{~nm}$ hullámhosszú lézer gerjesztéssel, $\leq 2,5 \mathrm{~mW}$ teljesítménnyel és $50 \mathrm{x}$ objektívvel.

\section{Röntgendiffraktometria (XRD):}

A fém- és nitrogén-adalékolt szenek vizsgálata során röntgendiffraktometriával a szén kristályosságának mértékéről, kristályos fémfázisok és esetleges szennyezések jelenlétéről kaphatunk információt. Kristályos szén esetén éles reflexiók jelennek meg, míg amorf minta vizsgálatánál széles, dombszerü jelet kapunk kb. $25^{\circ}$ és $41^{\circ} 2 \Theta$ értékeknél, melyek a grafit (002) és (100) Miller-indexü kristálysíkjaihoz rendelhetők. ${ }^{118}$

A röntgendiffraktogramokat egy Rigaku Miniflex II müszerrel vettük fel $2 \Theta=10^{\circ}-80^{\circ}$ tartományon $1^{\circ} \min ^{-1}$ pásztázási sebességgel $\mathrm{Cu} \mathrm{K}_{\alpha}$, sugárzás alkalmazásával $(\lambda=0,1541 \mathrm{~nm})$.

\section{$\underline{\text { Röntgen-fotoelektron spektroszkópia (XPS): }}$}

A röntgen-fotoelektron spektroszkópia kiemelten fontos felületvizsgálati módszer a $\mathrm{N}$-adalékolt szenek vizsgálatában. Információt kaphatunk a katalizátor felületének elemi összetételéről (pl. relatív C, N, O tartalom), valamint a különböző kémiai környezetben lévő atomok arányáról (nagy felbontású N1s és C1s spektrumok). A leggyakrabban előforduló N-típusokat a hozzájuk tartozó kötési energia értékekkel a 15. ábra foglalja össze. ${ }^{38,119}$

Az XPS spektrumok felvételéhez egy Kratos Axis Ultra DID spektrométert használtunk monokromatikus Al Ka sugárzással $(300 \mathrm{~W})$. Töltés kompenzációra nem volt szükség. A spektrumok analízise CasaXPS szoftver segítségével történt. Az analizátor középvonalán áthaladó elektronokra jellemző energia (,pass energy”) az áttekintő spektrumok felvétele során 80 eV, míg a nagyfelbontású C1s és N1s spektrumok felvételénél 20 eV volt. A nagyfelbontású spektrumokat 70\% Gauss / 30\% Lorentz görbékkel illesztettük, a félértékszélességeket (FWHM) a C esetén 1,0-1,2 V eV között, míg a N esetén 1,3-1,5 eV között fixáltuk. ${ }^{38,119}$ 


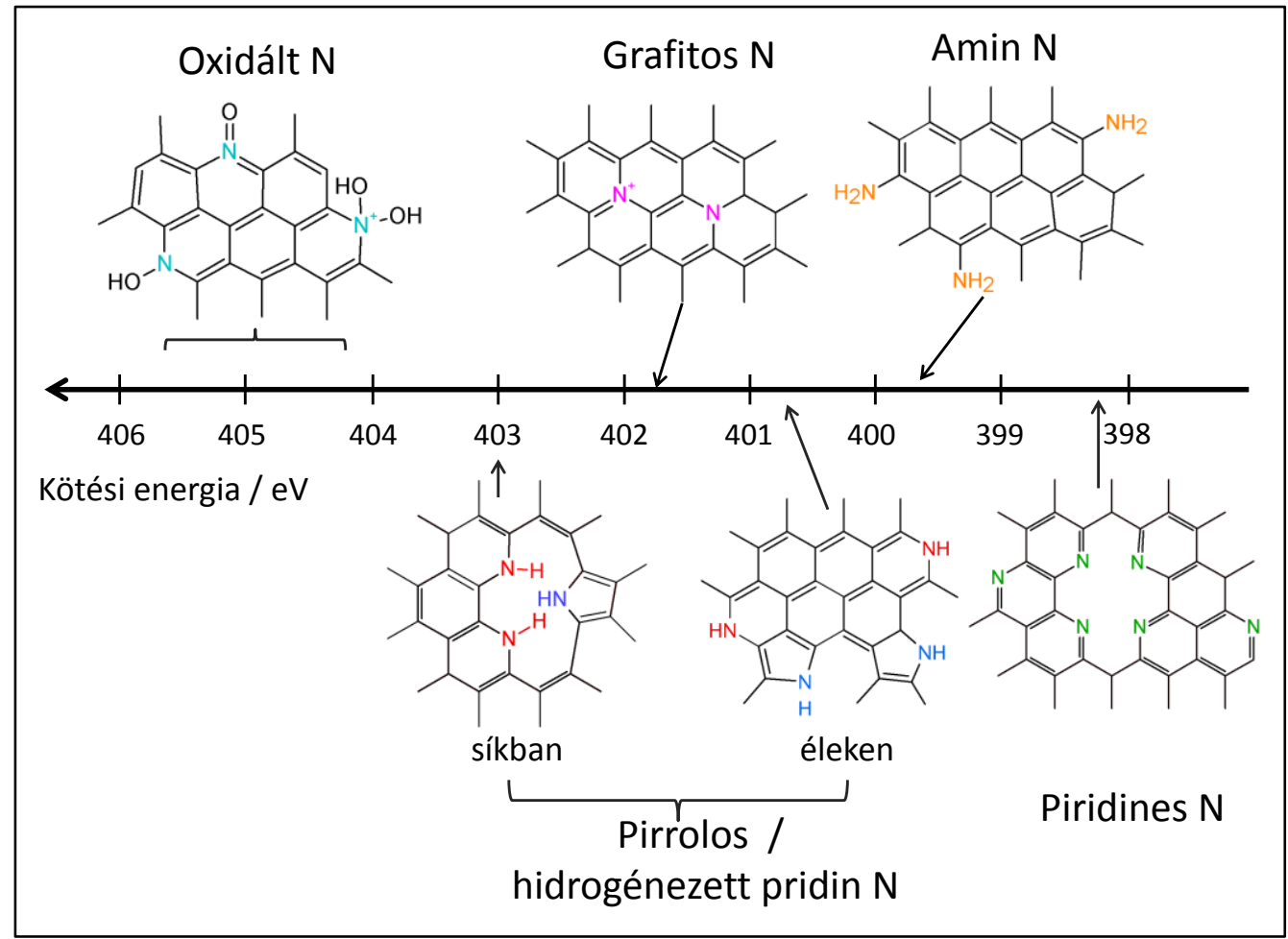

15. ábra: N-adalékolt szén katalizátorokban leggyakrabban előforduló N- típusok a hozzájuk tartozó kötési energiákkal.

$\underline{N}_{2}$ adszorpciós / deszorpciós vizsgálatok:

$\mathrm{N}_{2}$ adszorpció / deszorpció mérésével a katalizátor minták fajlagos felületét és pórusszerkezetét vizsgáltuk. Az adszorpciós / deszorpciós izotermákat egy Quantachrome Nova 3000e müszerrel vettük fel 77,4 K-en. Az izotermák felvétele előtt a mintákat két órán keresztül $200^{\circ} \mathrm{C}$-on vákuumban kezeltük elő az adszorbeált gázok eltávolítása céljából.

A fajlagos felületet többpontos Brunauer-Emett-Teller (BET) analízissel az adszorpciós ágból határoztuk meg $0,05<\mathrm{p} / \mathrm{p}^{\circ}<0,3$ relatív nyomás tartományon. A pórusméret eloszlás görbéket a mezopórusok tartományában az izotermák adszorpciós ágából a Barret-JoynerHalenda $(\mathrm{BJH})$ módszerrel számítottuk. Ennek során a $\mathrm{p} / \mathrm{p}^{\circ}<0,35$ pontokat figyelmen kívül hagytuk. $^{120}$

\section{Transzmissziós elektronmikroszkópia (TEM):}

Transzmissziós elektronmikroszkópiával a templát szintézis során használt szilika nanorészecskék méretét és méreteloszlását, valamint a vizsgált katalizátorok morfológiáját és pórusszerkezetét vizsgáltuk. A TEM felvételeket egy FEI Tecnai G2 20X-Twin elektronmikroszkóppal készítettük 200 kV gyorsító feszültség mellett. 
Pásztázó elektronmikroszkópia (SEM):

Pásztázó elektronmikroszkópiával a katalizátorok morfológiáját tanulmányoztuk. A SEM felvételeket egy Hitachi S4700 téremissziós elektronmikroszkóppal készítettük 10 kV gyorsítófeszültség alkalmazásával.

\section{Peremszög mérés:}

A katalizátor vékonyrétegek nedvesedési tulajdonságait dinamikus haladó $\left(\Theta_{\mathrm{adv}}\right)$ és hátráló $\left(\Theta_{\mathrm{rec}}\right)$ peremszögek mérésével vizsgáltuk. Tesztfolyadékként desztillált vizet használtunk $\left(25^{\circ} \mathrm{C}\right.$, atmoszférikus nyomás, állandó páratartalom), a peremszöget egy Krüss GmbH EasyDrop műszer és DSA100 szoftver segítségével határoztuk meg. A katalizátor rétegek teljes látszólagos felületi energia értékeit $\left(\gamma_{\mathrm{s}, \mathrm{tot}}\right)$ a dinamikus peremszög értékekböl számoltuk a 9. egyenlet alapján, a víz felületi feszültségének ismeretében $\left(\gamma_{1}=72,1 \mathrm{mN} \mathrm{m}^{-1} ; 25\right.$ $\left.{ }^{\circ} \mathrm{C}\right) .{ }^{121}$

$$
\gamma_{\mathrm{s}}^{\mathrm{tot}}=\left(\frac{\gamma_{\mathrm{l}}\left(1+\cos \theta_{\mathrm{adv}}\right)^{2}}{\left(2+\cos \theta_{\mathrm{rec}}+\cos \theta_{\mathrm{adv}}\right)}\right)
$$

Hőmérséklet programozott $\mathrm{CO}_{2}$ deszorpció (TPD):

A $\mathrm{CO}_{2}$ redukció során a reaktáns és a köztitermékek katalizátorhoz való kötődésének erőssége döntő szerepet játszik a katalitikus aktivitás és szelektivitás meghatározásában. $\mathrm{A} \mathrm{CO}_{2}$ kötéserősségét hőmérséklet programozott deszorpció mérésével vizsgáltuk egy BELCAT-A típusú készülékkel. A méréseket megelőzően a vizsgálandó mintákat egy órán keresztül $\mathrm{N}_{2}$ atmoszférában $500{ }^{\circ} \mathrm{C}$-on kezeltük elő az adszorbeált komponensek eltávolítása céljából. Ezt követően a katalizátorokat $\mathrm{He}$ áramban $50^{\circ} \mathrm{C}$-ra fütöttük, majd ugyanezen a hömérsékleten 30 percen keresztül adszorbeáltattuk a $\mathrm{CO}_{2}$-ot. A nem adszorbeált $\mathrm{CO}_{2}$-ot egy 15 perces héliumos öblítéssel távolítottuk el. Ezekben a lépésekben a gázok áramlási sebessége $50 \mathrm{~mL} \mathrm{~min}{ }^{-1}$ volt. A deszorpciós lépésben a katalizátor mintákat $\mathrm{He}$ áramban $\left(30 \mathrm{~mL} \mathrm{~min}^{-1}\right) 10^{\circ} \mathrm{C} \mathrm{min}{ }^{-1}$ felfútési sebességgel $500{ }^{\circ} \mathrm{C}$-ra fütöttük és a deszorbeált $\mathrm{CO}_{2}$-ot egy hővezetőképességi detektorral (TCD) analizáltuk.

\subsubsection{Elektrokémiai módszerek}

Az elektrokémiai méréseket egy AUTOLAB PGSTAT 204 potenciosztát-galvanosztát müszerrel végeztük háromelektródos elrendezésben. A munkalektród az üvegszén hordozóra 
felvitt katalizátor minta volt, ellenelektródként egy Pt lemezt, míg referencia elektródként egy $\mathrm{Ag} / \mathrm{AgCl} / 3 \mathrm{M} \mathrm{NaCl}$ elektródot használtunk, melynek elektródpotenciálja $+0,210 \mathrm{~V}$ a standard hidrogénelektródhoz képest (SHE), $25{ }^{\circ} \mathrm{C}-o n$. A mért elektródpotenciál értékeket az értekezésben minden esetben a reverzibilis hidrogén elektródhoz (RHE) képest adtam meg:

$$
E(\text { vs. } \mathrm{RHE})=E(\text { vs. } \mathrm{Ag} / \mathrm{AgCl} / 3 \mathrm{M} \mathrm{NaCl})+0,059 \cdot p H+0,210 \mathrm{~V} \text {. (10) }
$$

\section{Ciklikus voltammetria:}

Az üvegszén elektródra felvitt katalizátor vékonyrétegek elektrokémiailag aktív felületét ciklikus voltammetriás mérésekböl becsültük. Amennyiben a vizsgált potenciál tartományon Faraday-folyamat nem játszódik le, az elektrokémiai kettősréteg feltöltéséhez és kisütéséhez rendelhető kapacitív áram nagysága (és a kettősréteg kapacitás, $C_{d l}$ ) arányos a vizsgált elektród elektrokémiai aktív felületével. Az elektrokémiai felület meghatározására két módszert alkalmaztunk:

(1) A katalizátor rétegek adott pásztázási sebességgel felvett ciklikus voltammogramjainak idő szerinti integrálásával meghatároztuk az áthaladt töltés abszolút értékét $\left(Q_{d l}\right)$, ami arányos az elektrokémiai felülettel. Összehasonlításként egy sima felületü üvegszén elektród azonos körülmények között felvett ciklikus voltammogramjából meghatározott tölrtést $\left(Q_{d l, r e f}\right)$ használtuk. Feltételezve, hogy az üres üvegszén elektród geometriai felülete megegyezik az elektrokémiai felületével, a vizsgált katalizátor réteg elektrokémiailag aktív felületét / érdességét a két töltés hányadosaként kaptuk $\left(r=Q_{d l} / Q_{d l, r e f}\right)$.

(2) Amennyiben különböző pásztázási sebességekkel vesszük fel a ciklikus voltammogramokat, majd a kettősréteg áramokat $\left(j_{d l}\right)$ a pásztázási sebességek függvényében ábrázoljuk, a pontokra illesztett egyenes meredekségéböl $(s)$ a kettősréteg kapacitás $\left(C_{d l}\right)$ számítható (16. ábra). A katalizátorok kettősréteg kapacitás értékeit összevetve egy ismert elektrokémiai felületü elektród kettősréteg kapacitásával $\left(C_{d l, r e f}\right)$, megkaphatjuk a vizsgált elektród elektrokémiailag aktív felületét / érdességét $(r): r=C_{d l} /$ $C_{d l, r e f .}$ 

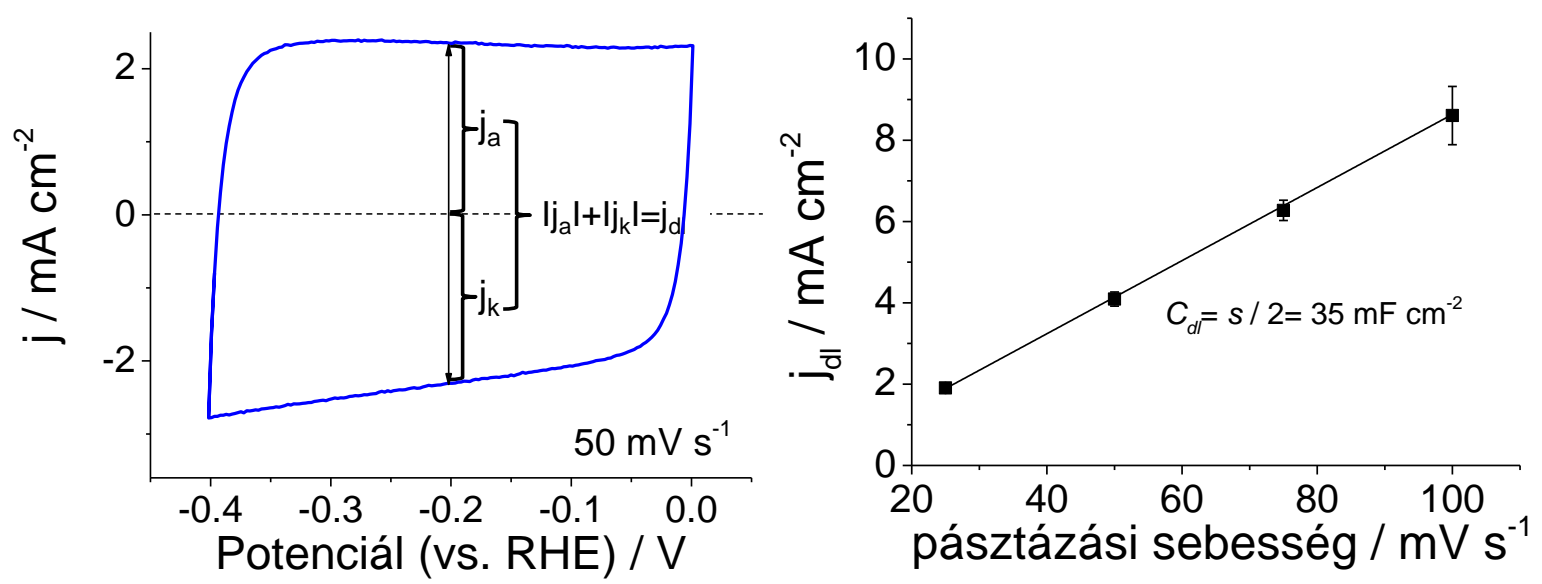

16. ábra: Az elektródok kettősréteg kapacitásának meghatározása ciklikus voltammetriás mérésekből. (A): A ciklikus voltammogramról leolvasható a kettősréteg áram $\left(\boldsymbol{j}_{d l}\right)$. (B): A $\boldsymbol{j}_{d l}$ értékeket a pásztázási sebesség függvényében ábrázolva, a pontokra illesztett egyenes meredekségéből a kettősréteg kapacitás számítható.

Lineáris voltammetria:

A katalizátorok elektroredukciós tulajdonságainak gyors tesztelését lineáris voltammetriával végeztünk. A voltammogramokat $\mathrm{CO}_{2}$-dal telített oldatban $\left(0,5 \mathrm{M} \mathrm{KHCO}_{3} /\right.$ $\left.\mathrm{CO}_{2}\right)$, illetve $\mathrm{CO}_{2}$ hiányában is $\left(0,5 \mathrm{M} \mathrm{K}_{2} \mathrm{SO}_{4} / \mathrm{Ar}\right)$ felvettük. A redukciós áramok nagysága és indulási potenciálja által összevethettük a különböző katalizátorok redukciós teljesítményét. A voltammogramok felvételét kis pásztázási sebességekkel végeztük $\left(5 \mathrm{mV} \mathrm{s}^{-1}\right)$ annak érdekében, hogy a kapacitív áramot minél kisebb értéken tartsuk. A kapacitív áramnak azonban ennek ellenére is jelentős hozzájárulása lehet a mért áramokhoz, különösen nagy elektrokémiai felületü elektródok esetén. A $\mathrm{CO}_{2}$ jelenlétében és annak hiányában felvett voltammogramok összehasonlítása alapján valószínüsíthettük azt a potenciáltartományt, ahol a $\mathrm{CO}_{2}$ redukció történik. Fontos azonban, hogy ez a módszer szelektivitásról nem ad információt, ehhez potenciosztatikus elektrolízis során keletkező termékek analízise szükséges.

\section{$\underline{\text { Potenciosztatikus elektrolízis: }}$}

A katalizátorok szelektivitását a potenciosztatikus elektrolízis közben keletkező termékek analízisével vizsgáltuk. Az elektrolízis kísérleteket a -0,5 - -0,9 V (vs. RHE) potenciáltartományon végeztük. A kísérleteket megelözően $\mathrm{CO}_{2}$-dal telítettük az elektrolit oldatot, majd légmentesen lezártuk a cellát és az elektrolízist statikus körülmények között hajtottuk végre. Az alkalmazott cella katód és anódterét egy Nafion-117 protoncsere membránnal választottuk el, hogy elkerüljük a két cellatérben keletkező termékek keveredését 
és a másik elektródon való reakciójukat. Adott időközönként mintát vettünk a gáz- és a folyadékfázisból a termékek analíziséhez. A Faraday-hatásfokok számításához az adott időpontig áthaladt összes töltést az áram idő szerinti integrálásával határoztuk meg. Potenciosztatikus mérésekkel a szelektivitás mellett az elektródok stabilitását is vizsgáltuk. A kísérleteket minden esetben háromszor végeztük el.

\section{Elektrokémiai impedancia spektroszkópia:}

$\mathrm{Az}$ elektrokémiai impedancia spektrumokat Ar-nal buborékoltatott $1 \mathrm{M} \mathrm{Na}_{2} \mathrm{SO}_{4}$ oldatban vettük fel egy zárt elektrokémiai cellában, nyitott áramköri potenciálon a $0,01 \mathrm{~Hz}-$ $100 \mathrm{kHz}$ frekvenciatartományon, szinuszos gerjesztőjelet használva (10 mV RMS amplitúdó).

Buborékfejlődés dinamikájának vizsgálata:

A $\mathrm{CO}_{2}$ redukció folyamán keletkező gáztermékek buborékok formájában távoznak az elektród felszínéről. A buborékok mérete és távozási gyakoriságuk szintén hatással lehet a redukciós folyamatra a reaktáns transzport elősegítésén keresztül és a katalitikus helyek elérhetőségének változása által. Az elektród felületről távozó buborékok méretét és tartózkodási idejüket egy digitális mikroszkóp (500 x nagyítás) és az ImageJ képanalízis szoftver segítségével vizsgáltuk potenciosztatikus elektrolízis közben.

\subsubsection{Redukciós termékek analízise}

\section{Gázkromatográfia:}

A $\mathrm{CO}_{2}$ redukció során keletkező gázfázisú termékeket on-line gázkromatográfiával vizsgáltuk egy kisülési ionizációs detektorral (BID) felszerelt Shimadzu 2010 Plus Tracera műszerrel. Az elektrolízis cella a gázkromatográffal közvetlen összeköttetésben volt. Mintavétel előtt a cella katódterének gázteréből egy perisztaltikus pumpa segítségével a mintahurokba juttattuk a vizsgálandó gázelegyet, ahonnan a minta egy hatutas szelep átfordításával került gázkromatográf injektorába.

Az analizálandó gázelegy elválasztására Shincarbon ST típusú kolonnát használtunk, mely alkalmas a $\mathrm{H}_{2}, \mathrm{O}_{2}, \mathrm{~N}_{2}, \mathrm{CO}, \mathrm{CO}_{2}$ és könnyü szénhidrogének elválasztására (17. ábra). Az általunk használt BID detektor nagy érzékenységü, univerzális detektor. A héliumon és a neonon kívül minden komponens érzékelhető vele, amivel elkerülhettük egy összetettebb, két detektoros (TCD + FID) rendszer használatát. Szervetlen gázokra és könnyủ szénhidrogénekre a kimutatási határ a ppm tartományban van. A kalibrációt $\mathrm{H}_{2}$-t, $\mathrm{CO}-\mathrm{t}, \mathrm{CH}_{4}$ - $\mathrm{t}_{\mathrm{s}} \mathrm{C}_{2} \mathrm{H}_{4}$-t tartalmazó 
gázelegyekkel végeztük az $1-10 \mathrm{~V} / \mathrm{V} \%$ koncentráció tartományban. Az optimalizált analízis paraméterek a következők voltak: vivőgáz: hélium; hömérséklet program: $35^{\circ} \mathrm{C}(2,5 \mathrm{~min})-20$ ${ }^{\circ} \mathrm{C} \min ^{-1}-270{ }^{\circ} \mathrm{C}(3 \mathrm{~min})$; injektor hömérséklet: $T=150{ }^{\circ} \mathrm{C}$; nyomásprogram: $250 \mathrm{kPa}(2,5$ min) - $15 \mathrm{kPa} \mathrm{min}{ }^{-1}-400 \mathrm{kPa}(7,5 \mathrm{~min})$; split arány: 10.

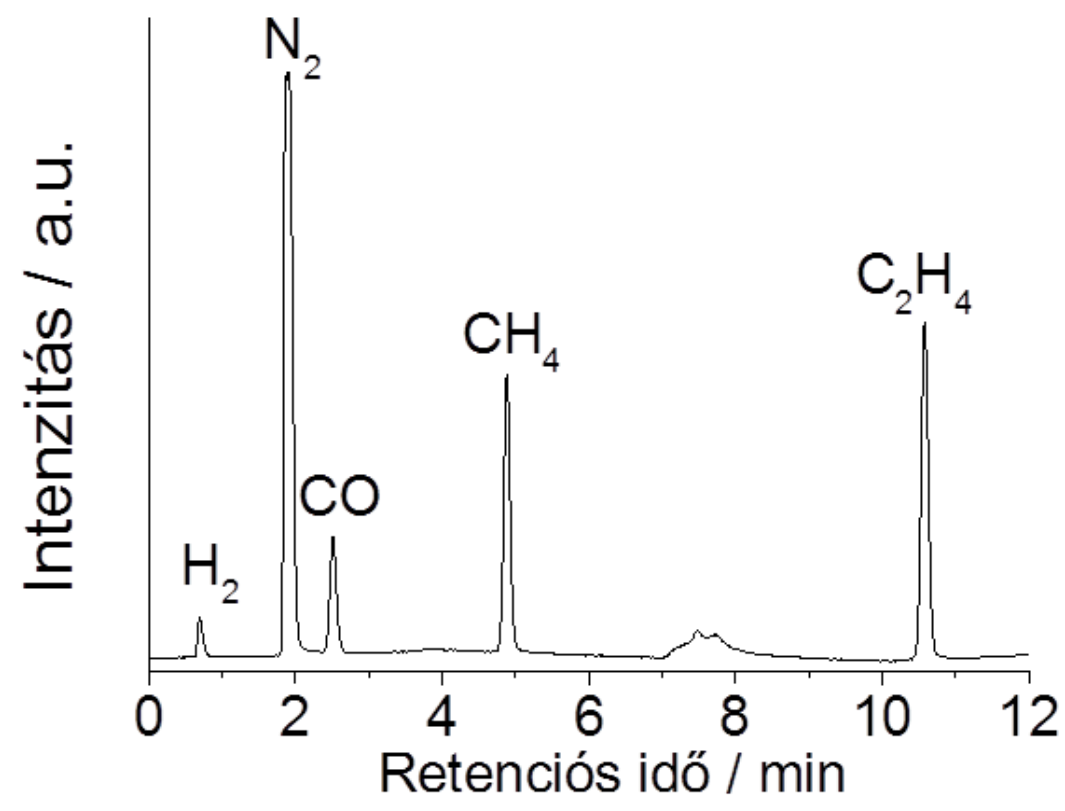

17. ábra: Egy hidrogént, szén-monoxidot, metánt, etilént (mindegyik komponens 5 V / V \%, vivőgáz: N2) tartalmazó gázelegy kromatogramja Shincarbon ST típusú kolonnán elválasztva GC-BID müszerrel.

A keletkező termékek mennyiségi meghatározását követően az áthaladt töltés ismeretében a Faraday-hatásfokot $(F E)$, valamint a parciális áramokat $\left(j_{p}\right)$ az (1)-es és (2)-es egyenletek szerint számítottuk.

\section{NMR-spektroszkópia:}

A folyadékfázisú $\mathrm{CO}_{2}$ redukciós termékeket ex situ ${ }^{1} \mathrm{H}$ NMR spektroszkópiával analizáltuk egy $500 \mathrm{MHz}$-es Bruker Avance készülékkel, vízelnyomásos módszerrel. A mennyiségi meghatározáshoz belső standard-es kalibrációt alkalmaztunk. Az analízis során 450 $\mu \mathrm{L}$ vizsgálandó elektrolithoz $50 \mu \mathrm{L} \mathrm{D}_{2} \mathrm{O}$-t adtunk, amely belső standardként $1,3 \mathrm{mM}$ fenolt és 0,8 mM dimetil-szulfoxidot (DMSO) tartalmazott. A kalibrációhoz a termékek és a belső standard komponensek jeléhez tartozó csúcsterületek arányait használtuk. A víz jelétől jobbra 
található komponensek esetén a DMSO, míg az attól balra található komponensek esetén a fenol jeléhez viszonyítottunk. Az alkalmazott módszer kimutatási határa 5-10 $\mu \mathrm{M}$ (256 scan).

\subsubsection{Izotópjelzéses kísérletek}

Kettôs izotópjelzéses kísérletekkel igazoltuk, hogy a redukció során keletkező CO valóban a $\mathrm{CO}_{2}$ átalakításából származott. Ennek során mind a hidrogén-karbonát elektrolit, mind pedig a szén-dioxid gáz ${ }^{13} \mathrm{C}$ jelzett volt. Szelektiv izotópjelzéses módszert használtunk a redukció mechanizmusának megismerésére. Ebben az esetben vagy csak a hidrogén-karbonát elektrolit, vagy csak a $\mathrm{CO}_{2}$ gáz volt ${ }^{13} \mathrm{C}$ jelzett, míg a másik komponens jelöletlen volt.

A szelektív izotópjelzéses kísérletek a következőképpen zajlottak:

(A) A jelölt komponens a $\mathrm{NaHCO}_{3}$ :

1. Az elektrokémiai cella katódterében $35 \mathrm{~cm}^{3}$ ioncserélt vizet ${ }^{12} \mathrm{CO}_{2}$ gázzal telítettünk;

2. A megfelelö mennyiségü $\mathrm{NaH}^{13} \mathrm{CO}_{3}$ sót $(0,1 \mathrm{M})$ kis mennyiségü, a katódtérből kivett ioncserélt vízben oldottuk, és az oldatot egy szeptumon keresztül visszajuttattuk a cellába;

3. $\mathrm{A}^{12} \mathrm{CO}_{2}$ buborékoltatását megszüntettük és légmentesen zártuk a cellát.

(B) A jelölt komponens a $\mathrm{CO}_{2}$ :

1. A katódtérben lévő $35 \mathrm{~cm}^{3}$ ioncserélt vizet Ar gázzal telítettük, hogy minden oldott gázt eltávolítsunk belőle;

2. 11 percen keresztül $42 \mathrm{~cm}^{3} \mathrm{~min}^{-1}$ áramlási sebességgel a katódtérben lévő vizet ${ }^{13} \mathrm{CO}_{2^{-}}$ dal telítettük;

3. A megfelelő mennyiségü $\mathrm{NaH}^{12} \mathrm{CO}_{3}$ sót feloldottuk a cellából kivett kis mennyiségü ${ }^{13} \mathrm{CO}_{2}$-dal telített vízben és a cellát lezártuk.

A szelektív izotópjelzéses kísérleteket egyensúlyi és nemegyensúlyi körülmények között is elvégeztük. Egyensúlyi esetben az elektrolízist a hidrogén-karbonát só cellába való juttatását követỏen két órával kezdtük, vagyis amikor a hidrogén-karbonát ionok és a $\mathrm{CO}_{2}$ gáz között a dinamikus egyensúly már beállt. A kétórás várakozás alatt az elektrolitot folyamatosan kevertettük. Nemegyensúlyi esetben az elektrolízist a hidrogén-karbonát só hozzáadása után azonnal indítottuk; ekkor a $\mathrm{CO}_{2}$ gáz izotópösszetétele eltért a hidrogén-karbonátétól.

A CO ${ }_{2}$ redukció során keletkező CO izotópösszetételét egy Shimadzu QP2010 S típusú GC-MS készülékkel vizsgáltuk szelektív ionkövetés módban. A jelöletlen és a jelölt CO 
molekulaionjához tartozó $\mathrm{m} / \mathrm{z}=28$ és $\mathrm{m} / \mathrm{z}=29$ jeleket használtuk az analízishez. A katódtér gázteréből $200 \mu \mathrm{L}$ mintát injektáltunk a GC-MS-be egy gáztömör fecskendő segítségével, minden tizedik percben. Az elválasztáshoz egy RT Molsieve 5 Å kolonnát használtunk, ami képes volt a $\mathrm{CO}_{2}$, a $\mathrm{CO}$ és a $\mathrm{N}_{2}$ elválasztására, így a $\mathrm{CO}_{2}$ és a $\mathrm{N}_{2}$ ionizációjából származó $\mathrm{m} / \mathrm{z}=$ 28 és $\mathrm{m} / \mathrm{z}=29$ jelek zavaró hatását kiküszöböltük. A GC-MS analízis paraméterei a következők voltak: hőmérsékletprogram: $90^{\circ} \mathrm{C}(0 \mathrm{~min})-10{ }^{\circ} \mathrm{C} \min ^{-1}-110{ }^{\circ} \mathrm{C}(0 \mathrm{~min})-30{ }^{\circ} \mathrm{C} \mathrm{min}{ }^{-1}-150$ ${ }^{\circ} \mathrm{C}$ (3 min); injektor hőmérséklet: $200{ }^{\circ} \mathrm{C}$; a lineáris áramlási sebességet a nyomás szabályozta $(\mathrm{p}=50 \mathrm{kPa})$; split arány: 50 .

A szelektív izotópjelzés során a katód gázterében lévő $\mathrm{CO}_{2}$ izotópösszetételének időbeli változását (elektrolízis nélkül) vizsgáló kísérlet során a GC-MS analízishez egy ZB-WAX Plus kolonnát használtunk. Ezen az oszlopon a $\mathrm{CO}_{2}$ nem kötődik, az m/z $=44,45,13,12$ ionok követésével a $\mathrm{CO}_{2}$ izotópösszetétele meghatározható.

\subsubsection{Heterogén katalitikus mérések}

$\mathrm{A} \mathrm{CO}_{2}$ termikus hidrogénezését egy állóágyas reaktorban vizsgáltuk $300{ }^{\circ} \mathrm{C}$ és $700^{\circ} \mathrm{C}$ között. A méréseket megelőzően a mintákat $(0,150 \mathrm{~g}) \mathrm{Ar}$ áramban $\left(60 \mathrm{~mL} \mathrm{~min}{ }^{-1}\right) 300{ }^{\circ} \mathrm{C}$-on kezeltük elö. A reakció során 1:4 arányú $\mathrm{CO} / \mathrm{H}_{2}$ gázelegyet használtunk $\left(50 \mathrm{~mL} \mathrm{~min}{ }^{-1}\right)$ és a képződő termékeket gázkromatográfiával analizáltuk. 


\section{Eredmények és értékelésük}

\subsection{Szén-dioxid redukció mechanizmusának vizsgálata izotópjelzéses kísérletekkel}

\subsubsection{A katalizátor szintézise és jellemzése}

Az izotópjelzéses kísérletek során alkalmazott HPG-PPy katalizátort egy polipirrolfitinsav hidrogél prekurzorból állítottuk elő egy szakirodalomban megtalálható szintézismódszer adaptálásával. ${ }^{98}$ Első lépésként a pirrol monomert fitinsav jelenlétében kémiailag polimerizáltuk és a kapott polipirrol hidrogélt liofilizálással szárítottuk. Ezt követően a polimert $900{ }^{\circ} \mathrm{C}$-on nitrogénáramban karbonizáltuk és az így képződött $\mathrm{N}$-adalékolt szenet kémiailag aktiváltuk. Ennek során a szenet tömény KOH-oldatban szuszpendáltuk, vákuumban szárítottuk és $800^{\circ} \mathrm{C}$-on $\mathrm{N}_{2}$-áramban hőkezeltük. A HPG-PPy katalizátort ioncserélt vízzel való alapos mosást és vákuumszárítást követően kaptuk. Az előállított HPG-PPy katalizátor szivacsszerű, pórusos morfológiájú (18. A ábra), fajlagos (BET) felülete $2430 \mathrm{~m}^{2} \mathrm{~g}^{-1}$. A fitinsav a szintézis során soft-templátként a pórusos szén struktúra kialakításában játszott szerepet. Polimerizáció során a protonált anilinnel elektrosztatikus kölcsönhatásba lép és a kialakuló polimer láncok között keresztkötéseket létrehozva egy háromdimenziós térhálós polimer hidrogél alakul ki. ${ }^{98}$ Viszonylag magas bomlási hőmérséklete $\left(\sim 380{ }^{\circ} \mathrm{C}\right)$ miatt a karbonizálás során továbbá megakadályozza a polimerben kialakult pórusok összeesését, segítve ezzel a pórusos szerkezet kialakulását. A KOH-os kezelés a porozitás és a fajlagos felület további növelésében segített.

A

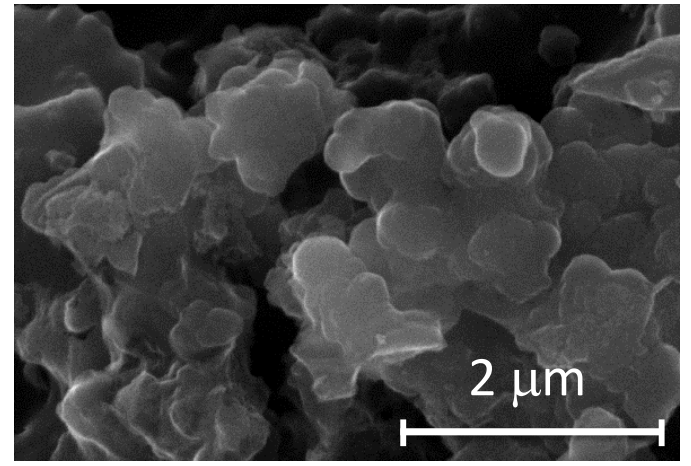

B

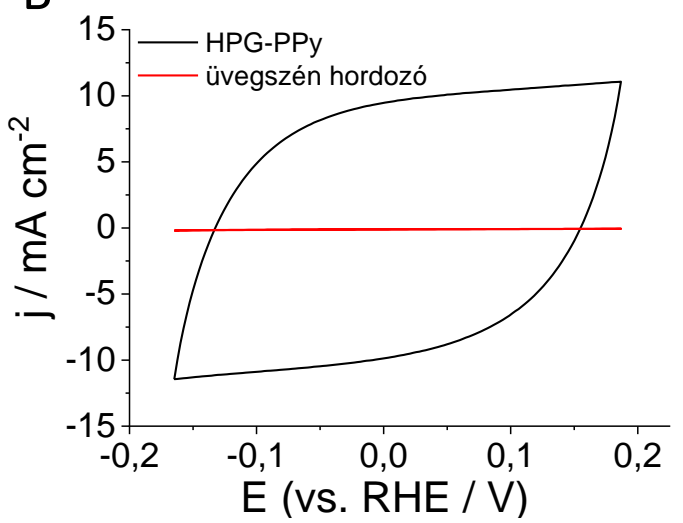

18. ábra: (A): A HPG-PPy katalizátor pásztázó elektronmikroszkópos képe. (B): A HPG-PPy elektród (2,1 $\mathrm{mg} \mathrm{cm}^{-2}$ borítottság) és az üvegszén hordozó elektród ciklikus voltammogramja $\mathrm{CO}_{2}$-dal telített 0,5 M $\mathrm{KHCO}_{3}$-oldatban, $50 \mathrm{mV} \mathrm{s}^{-1}$ pásztázási sebességgel. 
Az elektrokémiai vizsgálatokhoz a HPG-PPy katalizátorból üvegszén elektródra porlasztással vékonyrétegeket hoztunk létre. A felvitt katalizátor tömege minden esetben 2,1 \pm $0,1 \mathrm{~m} \mathrm{~cm}^{-2}$ volt. A 18. B ábrán látható az így készített elektród ciklikus voltammogramja $-0,16$ és $0,18 \mathrm{~V}$ (vs. RHE) közötti potenciáltartományon, ahol Faraday-folyamat nem történik. A voltammogram csak kismértékủ torzulást mutatott az ideális téglalap alakhoz képest, ami az elektród jó elektromos vezetését jelezte. A nagy kapacitív áram (összevetve egy üres üvegszén elektród ciklikus voltammogramjával) nagy elektrokémiai felületre utal, összhangban a $\mathrm{N}_{2}$ adszorpciós / deszorpciós mérésekkel (BET-felület).

\subsubsection{A katalizátor aktivitása a $\mathrm{CO}_{2}$ redukcióban}

A HPG-PPy elektród $\mathrm{CO}_{2}$ redukciós aktivitását lineáris voltammetriával és a potenciosztatikus elektrolízis során keletkezö termékek analízisével vizsgáltuk. $\mathrm{CO}_{2}$ jelenlétében $\left(0,5 \mathrm{M} \mathrm{KHCO}_{3} / \mathrm{CO}_{2}\right)$ a redukciós áram $\mathrm{kb}$. $100 \mathrm{mV}$-tal pozitívabb potenciálon indult a $\mathrm{CO}_{2}$ hiányában mérthez képest $(0,5 \mathrm{M}$ foszfát-puffer / Ar), továbbá a $-0,43$ és $-0,8 \mathrm{~V}$ közötti tartományon áramtöbblet jelentkezett (19. A ábra). Ez nagy valószínüséggel a $\mathrm{CO}_{2}$ redukciójához köthető, ezért a további vizsgálatokat $-0,6 \mathrm{~V}$ és $-0,7 \mathrm{~V}$ potenciálokon végeztük. A -0,7 V-on felvett kronoamperometriás görbe a 19. B ábrán látható. Az elektrolízis kezdetén az áram meredeken csökkent, ami nagymértékben a kapacitív áram lecsengéséhez rendelhetö. Ezt követően $-0,7 \mathrm{~mA} \mathrm{~cm}{ }^{-2}$ érték körül stabilizálódott és csupán kis mértékben csökkent az elektrolízis további ideje alatt $(2 \mathrm{~h})$. A redukció során termékként $\mathrm{CO}$ és $\mathrm{H}_{2}$ keletkezett, a vizsgált túlfeszültségen közel 1:1 arányban. Mennyiségük az áthaladt töltéssel lineárisan nőtt (19. C ábra). 

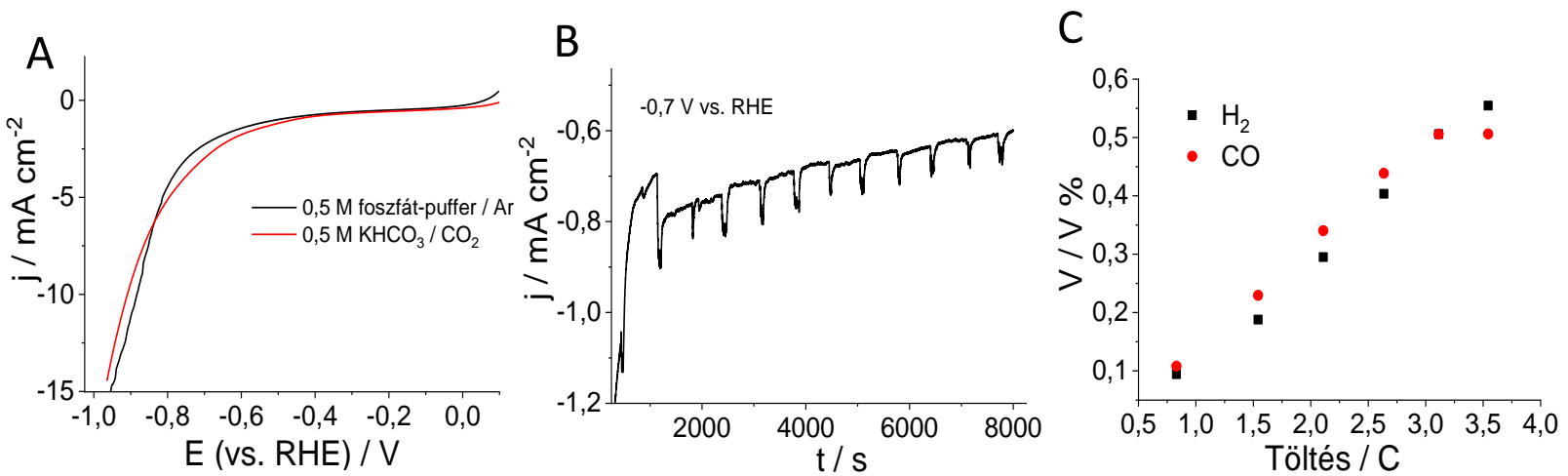

19. ábra: (A): A HPG-PPy elektród lineáris voltammogramja Ar-nal telített $0,5 \mathrm{M}$ foszfát-pufferben $(\mathrm{pH}=6,7)$ és $\mathrm{CO}_{2}$-dal telített 0,5 $\mathrm{M} \mathrm{KHCO}_{3}$ oldatban $5 \mathrm{mV} \mathrm{s}^{-1}$ pásztázási sebességgel. (B): A HPG-PPy elektród kronoamperometriás görbéje -0,7 V-on $\mathrm{CO}_{2}$-dal telített 0,5 M $\mathrm{KHCO}_{3}$ oldatban. (C): A keletkezö $\mathrm{CO}$ és $\mathrm{H}_{2}$ mennyisége az áthaladt töltés függvényében $-0,7 \mathrm{~V}$-on.

Kettős izotópjelzéses kísérlettel igazoltuk, hogy a képződő $\mathrm{CO}$ valóban a $\mathrm{CO}_{2}$ redukciójából származott. Ekkor a potenciosztatikus elektrolízis során mind a $\mathrm{CO}_{2}$ gáz, mind pedig $\mathrm{NaHCO}_{3}$ só ${ }^{13} \mathrm{C}$ jelzett volt. A képződő $\mathrm{CO}$ izotópösszetételét GC-MS segítségével vizsgáltuk az $\mathrm{m} / \mathrm{z}=28$ és 29 ionok szelektív követésével, melyek rendre a ${ }^{12} \mathrm{CO}$ és a ${ }^{13} \mathrm{CO}$ molekulaionjaihoz köthetök. Ezen körülmények között a keletkezö CO 98\%-ban ${ }^{13} \mathrm{C}$ jelzett volt és a ${ }^{12} \mathrm{CO} /{ }^{13} \mathrm{CO}$ koncentrációarány közel állandó volt a kétórás elektrolízis során (20. ábra). A kb. $2 \%{ }^{12} \mathrm{CO}(\mathrm{m} / \mathrm{z}=28)$ a $\mathrm{CO}_{2}$ gáz és a hidrogén-karbonát só ${ }^{12} \mathrm{C}$ tartalmából származott. Ezzel a kísérlettel tehát igazoltuk, hogy a $\mathrm{CO}$ a $\mathrm{CO}_{2} /$ hidrogén-karbonát rendszer átalakításából származott, nem pedig a katalizátor esetleges degradálódásából.
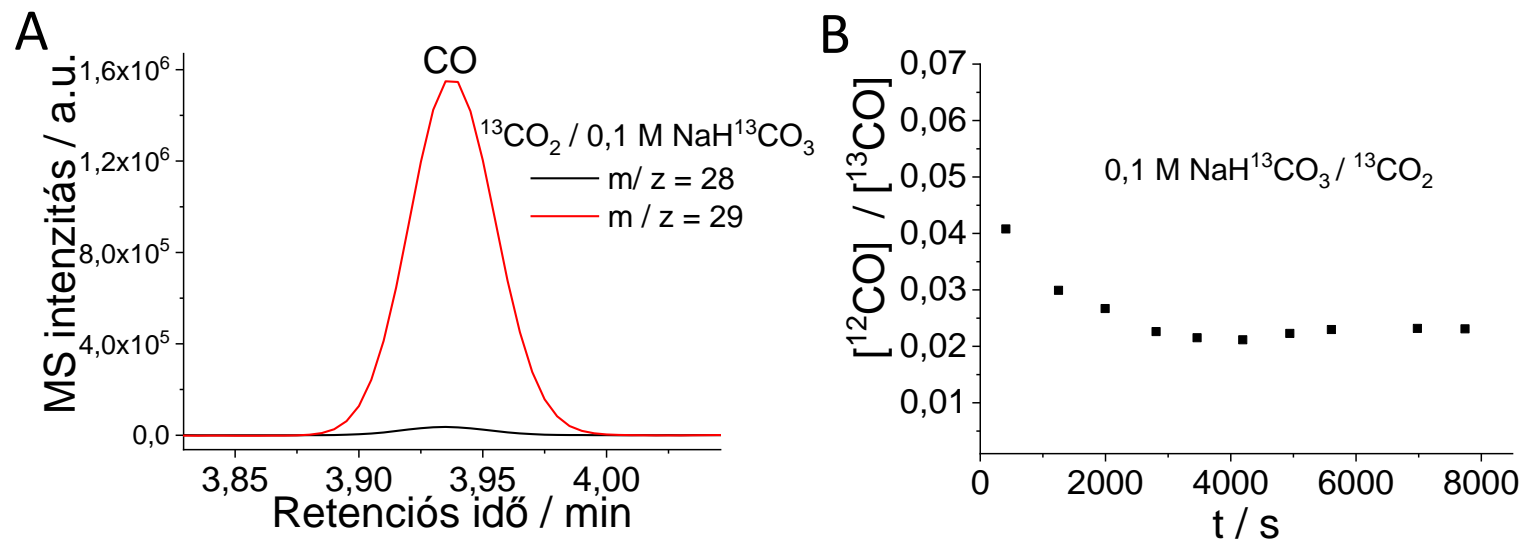

20. ábra: (A): A CO 2 redukció során (-0,7 V vs. RHE) keletkező CO GC-MS jele szelektív ion követés módban a kettős izotópjelzéses kísérlet során. $\mathrm{A}^{12} \mathrm{CO}$ és a ${ }^{13} \mathrm{CO}$ molekulaionjához köthető $\mathrm{m} / \mathrm{z}=28$ és $\mathrm{m} / \mathrm{z}=29$ ionokat követtük. (B) A keletkezö ${ }^{12} \mathrm{CO}$ és ${ }^{13} \mathrm{CO}$ arányának időbeli változása az elektrolízis során. 


\subsubsection{Szelektív izotópjelzéses kísérletek}

Szelektív izotópjelzéses kísérletek segítségével vizsgáltuk az N-C elektródokon lejátszódó $\mathrm{CO}_{2}$ redukció mechanizmusát. Célunk volt fényt deríteni arra, hogy az oldott széndioxid $\left(\mathrm{CO}_{2, \text { aq }}\right)$ vagy a hidrogén-karbonát ionok-e a közvetlenül reagáló részecskék az elektród felületén. Ennek érdekében elektrolízis kísérleteket végeztünk olyan körülmények között, hogy vagy csak a $\mathrm{CO}_{2}$ gáz, vagy csak a hidrogén-karbonát só volt a ${ }^{13} \mathrm{C}$ jelzett komponens (míg a másik nem jelzett). A $\mathrm{CO}_{2}$, illetve a keletkező $\mathrm{CO}$ izotópösszetételét GC-MS segítségével követtük.

A kísérlet alapját az a tény adta, hogy a hidrogén-karbonát ionok $\left(\mathrm{HCO}_{3}{ }^{-}\right.$aq $)$és a $\mathrm{CO}_{2}$ gáz $\left(\mathrm{CO}_{2, \mathrm{~g}}\right)$ közötti dinamikus egyensúly elérése nem pillanatszerü, hanem mintegy két óra szükséges az egyensúly beállásához (adott cellageometria esetén). Ennek bizonyítására szelektív izotópjelzéses körülmények között $\left(\mathrm{NaH}^{13} \mathrm{CO}_{3}\right.$ és $\left.{ }^{12} \mathrm{CO}_{2}\right)$, az elektrolízis cella gázterében lévő $\mathrm{CO}_{2}$ izotópösszetételét vizsgáltuk az időben elektrolizis nélkül. A kísérlet során (i) a cellában ${ }^{12} \mathrm{CO}_{2}$-dal telítettük az ioncserélt vizet, (ii) egy szeptumon keresztül a cellába juttattuk és oldottuk a $\mathrm{NaH}^{13} \mathrm{CO}_{3}$ sót, majd (iii) légmentesen zártuk a cellát. Így elértük azt, hogy a kísérlet kezdetén (a $\mathrm{NaH}^{13} \mathrm{CO}_{3}$ hozzáadásának pillanatában) gyakorlatilag az összes $\mathrm{HCO}_{3}{ }^{-}{ }_{\text {aq }}{ }^{13} \mathrm{C}$ jelzett, míg az összes $\mathrm{CO}_{2}$ (oldott + gáz) jelöletlen volt. Ezt követően a gázfázisú $\mathrm{CO}_{2}$ izotópösszetételének időbeli változását vizsgáltuk GC-MS segítségével két órán keresztül az oldat folyamatos kevertetése közben (21. ábra).

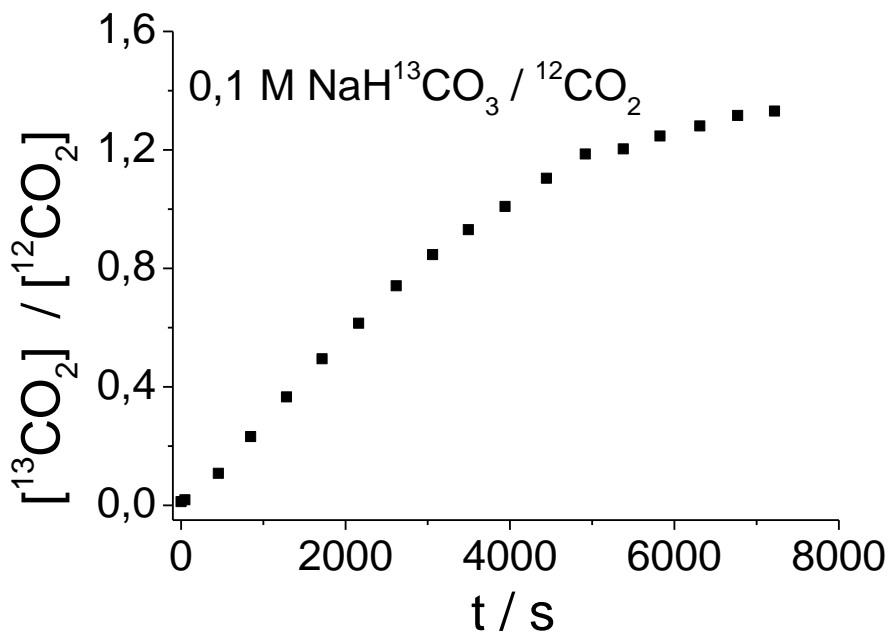

21. ábra: Egy zárt $\mathrm{HCO}_{3}^{-} / \mathrm{CO}_{2}$ rendszerben a gázfázisú $\mathrm{CO}_{2}$ izotópösszetételének időbeli változása szelektív izotópjelzéses körülmények között, amennyiben a kiindulási hidrogén-karbonát só volt a ${ }^{13} \mathrm{C}$ jelzett. 
Kezdetben (1 perccel a $\mathrm{NaHCO}_{3}$ hozzáadása után) a $\mathrm{CO}_{2}$ gáz csupán $1,5 \%{ }^{13} \mathrm{CO}_{2}$-t tartalmazott. $\quad \mathrm{A}^{13} \mathrm{CO}_{2} /{ }^{12} \mathrm{CO}_{2}$ koncentrációarány ezt követöen folyamatosan növekedett, míg kb. 1,5 óra után telítési értéket vett fel, ami közel megegyezett a ${ }^{13} \mathrm{C} /{ }^{12} \mathrm{C}$ bemérési aránnyal $(\sim 1,5)$. Ennek tükrében, szelektív izotópjelzéses körülmények között végzett $\mathrm{CO}_{2}$ redukció során, a keletkező CO izotópösszetételének időbeli követésével, a hidrogén-karbonát só hozzáadását követő mintegy egy órában különbséget tudunk tenni a $\mathrm{CO}_{2, \mathrm{~g}}$ és a $\mathrm{HCO}_{3}{ }^{-}{ }_{\mathrm{aq}}$, mint reaktáns között.

A szelektív izotópjelzéses elektrolízis kísérleteket végrehajtottuk mind a hidrogénkarbonát só, mind pedig a $\mathrm{CO}_{2}$ gáz jelölése mellett $\left({ }^{12} \mathrm{CO}_{2} / \mathrm{NaH}^{13} \mathrm{CO}_{3}\right.$ és $\left.{ }^{13} \mathrm{CO}_{2} / \mathrm{NaH}^{12} \mathrm{CO}_{3}\right)$, továbbá egyensúlyi és nemegyensúlyi körülmények között is vizsgáltuk a folyamatot. Nemegyensúlyi körülmények között az elektrolízist a hidrogén-karbonát só hozzáadását követően azonnal, míg egyensúlyi körülmények között ezt követően két órával indítottuk.
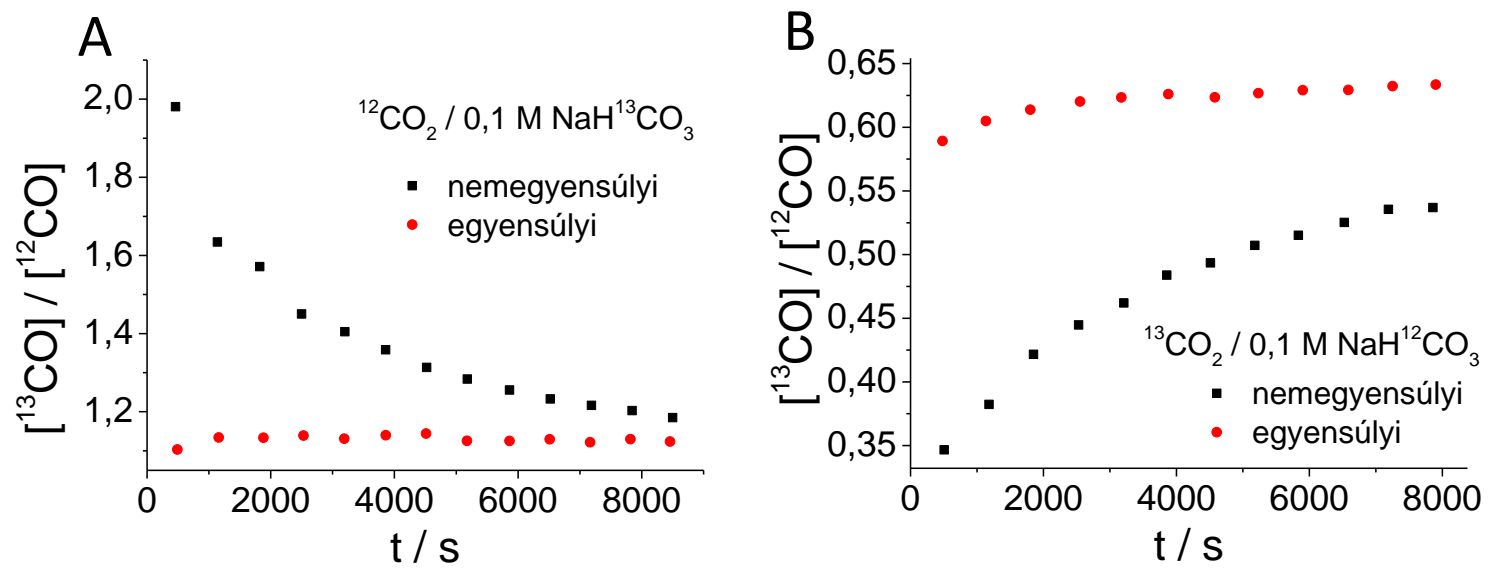

22. ábra: $\mathrm{A}^{13} \mathrm{CO}$ és a ${ }^{12} \mathrm{CO}$ koncentrációaránya $-0,7 \mathrm{~V}$-on szelektív izotópjelzéses körülmények között, amikor a $\mathrm{NaHCO}_{3}(\mathrm{~A})$, illetve a $\mathrm{CO}_{2}$ (B) volt az izotópjelzett komponens.

Abban az esetben, amikor a $\mathrm{NaH}^{13} \mathrm{CO}_{3}$ volt a jelzett komponens és nemegyensúlyi körülmények között vizsgáltuk a folyamatot (22. A ábra), a kísérlet első órájában a keletkező $\mathrm{CO}$ nagyobb része ${ }^{13} \mathrm{C}$ jelzett volt. A $\left[{ }^{13} \mathrm{CO}\right] /\left[{ }^{12} \mathrm{CO}\right]$ arány időben fokozatosan csökkent és a kétórás elektrolízis végére megközelítette az egyensúlyi körülmények között tapasztalt, közel állandó értéket $\left(\left[{ }^{13} \mathrm{CO}\right] /\left[{ }^{12} \mathrm{CO}\right] \cong 1,1\right)$. Amikor a ${ }^{13} \mathrm{CO}_{2}$ volt a jelzett komponens (22. B ábra), ezzel éppen ellentétes trendet figyeltünk meg: a $\left[{ }^{13} \mathrm{CO}\right] /\left[{ }^{12} \mathrm{CO}\right]$ koncentrációarány időben fokozatosan nőtt. A nemegyensúlyi oldatok esetén tehát a keletkező CO izotópösszetétele a kiindulási hidrogén-karbonát sóét tükrözte. Ez alapján két lehetséges reakcióutat valószínüsíthettünk: 
(i) a $\mathrm{CO}$ közvetlenül a $\mathrm{HCO}_{3, \text { aq }}^{-}$redukciójából származik;

(ii) a $\mathrm{CO}$ a gyors $\mathrm{CO}_{2, a q}+\mathrm{H}_{2} \mathrm{O} \leftrightharpoons \mathrm{HCO}_{3, a q}^{-}+\mathrm{H}^{+}$egyensúlyon keresztül a hidrogénkarbonát ionokból az elektród közelében pótlódó $\mathrm{CO}_{2, a q}$ átalakításából származik.

\subsubsection{Kontroll kísérletek}

Annak érdekében, hogy kiderítsük, melyik a valószínübb a fentebb javasolt reakcióutak közül, kontroll elektrolízis kísérleteket végeztünk a keletkező termékek analízisével együtt. A kísérleteket olyan pH-értékü oldatokban hajtottuk végre, melyekben dominánsan egyféle oldott részecske található (10. ábra). $\mathrm{Ha}$ a $\mathrm{pH} \leq 4, \mathrm{a}_{2, \text { aq }}$ a domináns részecske, míg $\mathrm{pH}=7$ és 9 között az oldat gyakorlatilag csak $\mathrm{HCO}_{3 \text {,aq }}$ ionokat tartalmaz. ${ }^{65} \mathrm{Az}$ elektrolízist ennek megfelelöen (i) egy $\mathrm{CO}_{2}$-dal telített $0,1 \mathrm{M}$ foszfát-pufferben ( $\mathrm{pH}=3,8$ ); (ii) egy Ar gázzal buborékoltatott $0,13 \mathrm{M} \mathrm{KHCO}_{3}$ oldatban $\left(\mathrm{pH}=8,8\right.$ ) és (iii) egy $\mathrm{CO}_{2}$-dal telített $0,1 \mathrm{M} \mathrm{KHCO}_{3}$ oldatban hajtottuk végre, a reverzibilis hidrogénelektróddal szemben azonos potenciálon $(-0,6$ $\mathrm{V}$ vs. RHE). Utóbbi oldatban (mely a $\mathrm{CO}_{2}$ redukció során gyakran használt elektrolit) a $\mathrm{HCO}_{3, \text { aq }}$ és a $\mathrm{CO}_{2, \text { aq }}$ koncentrációja közel megegyezik. Az ezekben az elektrolitokban mért CO-ra és $\mathrm{H}_{2}-$ re vonatkozó Faraday-hatásfokok a 23. ábrán láthatók.

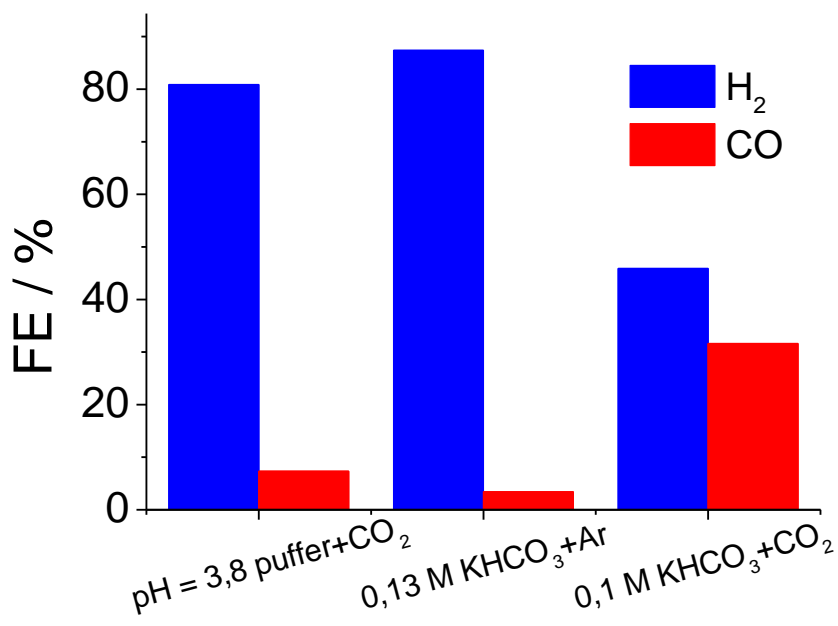

23. ábra: A H2- és CO-fejlődés Faraday-hatásfoka -0,6 V-on (vs. RHE) az elektrolízis 75. percében különböző elektrolitokban: (i): $\mathrm{CO}_{2}$-dal telített $0,1 \mathrm{M}$ foszfát-puffer $(\mathrm{pH}=3,8)$; (ii): Ar-nal buborékoltatott $0,13 \mathrm{M} \mathrm{KHCO}_{3}(\mathrm{pH}=8,8) ; \mathrm{CO}_{2}$-dal telített 0,1 M KHCO $3(\mathrm{pH}=6,6)$.

A CO képződésének Faraday-hatásfoka ( $\left.\mathrm{FE}_{\mathrm{CO}}\right) 31,6 \%$ volt a $\mathrm{CO}_{2}$-dal telített 0,1 $\mathrm{M}$ $\mathrm{KHCO}_{3}$ oldatban, 3,4 \% az Ar-nal buborékoltatott 0,13 $\mathrm{M} \mathrm{KHCO}_{3}$-oldatban és 7,3\% a CO -dal $^{2}$ 
telített $\mathrm{pH}=3,8$ pufferben. Az oldott $\mathrm{CO}_{2}$ becsült koncentrációja a három oldatban rendre 35 $\mathrm{mM}, 0,8 \mathrm{mM}$ és $33 \mathrm{mM}$ (3. táblázat). ${ }^{114} \mathrm{~A} \mathrm{CO}_{2}$-dal telített $\mathrm{pH}=3,8$ pufferben a közel kétszeres CO-szelektivitás növekedés a $0,13 \mathrm{M} \mathrm{KHCO}_{3}$ / Ar oldathoz képest valószínüleg az elöbbi oldat lényegesen nagyobb $\mathrm{CO}_{2 \text {,aq }}$ koncentrációjából eredt. Bár a 0,1 $\mathrm{M} \mathrm{KHCO}_{3} / \mathrm{CO}_{2}$ és a pH=3,8 foszfát-puffer $/ \mathrm{CO}_{2}$ oldatok teljes oldott szén-tartalma $\left(\mathrm{CO}_{2, a q}+\mathrm{HCO}_{3}^{-}\right.$aq $)$közel megegyezik, a $\mathrm{CO}_{2, \text { aq }}$ koncentráció mintegy 40-szer nagyobb a $0,1 \mathrm{M} \mathrm{KHCO}_{3} / \mathrm{CO}_{2}$ rendszerben. Továbbá ebben az oldatban a pH-viszonyok és a nagyobb hidrogén-karbonát koncentráció miatt az elektród közelében a reakció során fogyó $\mathrm{CO}_{2, \mathrm{aq}}$ a hidrogén-karbonát ionokból gyorsan pótlódhat. Valószínüleg ezen okok vezettek a vizsgált rendszerek között a $\mathrm{CO}_{2}$-dal telített 0,1 $\mathrm{M} \mathrm{KHCO}_{3}$ oldatban mért legnagyobb CO-szelektivitáshoz.

3. táblázat: A kontroll kísérletek során használt elektrolitok becsült $\mathrm{CO}_{2}$,aq koncentrációja és pH-értéke elektrolízis előtt és után.

Elektrolit

(i) $0,1 \mathrm{M}$ foszfát-puffer / $\mathrm{CO}_{2}$

(ii) $0,13 \mathrm{M} \mathrm{KHCO} / \mathrm{Ar}$

(iii) $0,10 \mathrm{M} \mathrm{KHCO} / \mathrm{CO}_{2}$
$\left[\mathrm{CO}_{2, \mathrm{aq}}\right] /$ $\mathbf{m M}$

\section{pH elektrolízis előtt pH elektrolízis után}

3,99

8,81

6,72

Összegezve az izotópjelzéses és a különböző elektrolitokban végzett elektrolízis

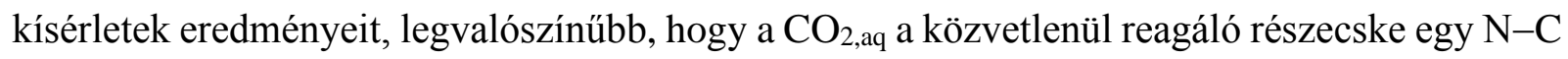
elektródon a $\mathrm{CO}_{2}$ redukcióban, azonban a hidrogén-karbonát elektrolit is kulcsszerepet játszik a nagy CO-szelektivitás elérésében. A hidrogén-karbonát ionok, mintegy $\mathrm{CO}_{2}$-pufferként közremüködve vesznek részt a folyamatban: az elektród közelében a $\mathrm{CO}_{2, \text { aq }}$ hidrogén-karbonát ionokból pótlódik, mivel ez az egyensúly sokkal gyorsabb, mint a gázfázisú $\mathrm{CO}_{2}$ oldódása és diffúziója az elektródhoz. ${ }^{65}$ Ezt a mechanizmust támasztja alá az izotópjelzéses kísérletek eredménye, miszerint a képződő $\mathrm{CO}$ izotópösszetétele a $\mathrm{HCO}_{3}{ }^{-}$aq izotópösszetételét tükrözte, amennyiben az izotópegyensúly még nem állt be. Szintén összhangban van azzal a megfigyeléssel, hogy a legnagyobb CO-szelektivitást a $\mathrm{HCO}_{3}-\mathrm{CO}_{2}$ rendszerben tapasztaltuk, míg lényegesen kisebb volt, amikor a $\mathrm{CO}_{2, \text { aq }}$ mellett nem volt jelentös mennyiségben $\mathrm{HCO}_{3 \text {, aq }}^{-}$ az oldatban. A hidrogén-karbonát ionok közvetlen redukciója nem valószínü, hiszen csak nagyon kis mennyiségben képződött CO, amikor gyakorlatilag csak hidrogén-karbonát ionok 
voltak jelen az oldatban. Végül ezt a javasolt reakcióutat valószínűsítették Ni-N-C elektródokon is a $\mathrm{CO}$ parciális áramsürüségének $\mathrm{HCO}_{3, a q}^{-}$- koncentrációtól való függésének alapján. ${ }^{122}$ 


\subsection{Nitrogénnel adalékolt szén elektródok pórusszerkezetének hatása a $\mathrm{CO}_{2}$ redukcióban}

Nitrogénnel adalékolt szén katalizátorok vizsgálatánál a morfológiai tényezők hatását gyakran figyelmen kívül hagyják a $\mathrm{CO}_{2}$ redukcióban. Holott a katalizátorok előállítása során a N-tartalom hangolása érdekében alkalmazott stratégiák (karbonizálás hőmérsékletének, prekurzorok minőségének változtatása), vagy akár a katalizátor készítésének módja jelentős mértékben befolyásolhatja a katalizátor porozitását / morfológiáját. Ez pedig többek között az anyagtranszport, vagy az aktív centrumok elérhetőségének változásán keresztül hatással lehet a redukciós folyamatokra is. $\mathrm{A} \mathrm{CO}_{2}$ redukcióban - ezt megelőzően - azonban még nem vizsgálták szisztematikusan ezt a hatást. Ennek érdekében különböző pórusméretü N-C katalizátorokat állítottunk elö, melyek a morfológián kívül egyéb fizikai-kémiai tulajdonságaikban közel megegyeztek, lehetőséget teremtve a porozitás $\mathrm{CO}_{2}$ redukcióra gyakorolt hatásának a vizsgálatára.

\subsubsection{A különböző porozitású katalizátorok előállítása}

A pórusos N-C katalizátorokat hard-templát módszerrel, PoPD prekurzor polimerekből állítottuk elő (24. ábra). Első lépésként az oPD monomert különböző részecskeméretű (13, 27, 90 nm átlagos átmérő) szilika kolloidok jelenlétében kémiailag polimerizáltuk. A kapott szilika / PoPD ( $\left.\mathrm{SiO}_{2} \mathrm{X} / \mathrm{PoPD}\right)$ kompozitokat inert atmoszférában $900{ }^{\circ} \mathrm{C}$-on karbonizáltuk, majd a szilika nanorészecskéket hidrogén-fluoriddal oldottuk ki az N-C struktúrákból. A különböző pórusméretü minták elöállítása során az oPD / $\mathrm{SiO}_{2}$ tömegarány megegyezett. A pórusos katalizátorokra a továbbiakban az NC-13, NC-27 és NC-90 neveken hivatkozom. Összehasonlításként egy nempórusos katalizátort $(\mathrm{NC})$ is előállítottunk szilika templát alkalmazása nélkül.

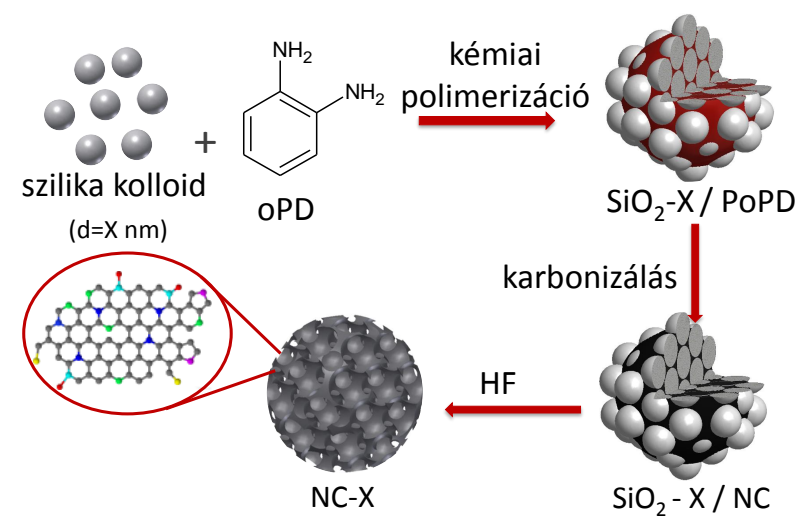

24. ábra: A pórusos N-C katalizátorok előállításának folyamata. 


\subsubsection{A katalizátorok szerkezeti jellemzése}

Az elektronmikroszkópos felvételeken megfigyelhető (25. ábra), hogy minden esetben összefüggő szénváz alakult ki a szintézis során, a pórusos minták esetén egységes méretü pórusokkal. A TEM felvételekből meghatároztuk az átlagos pórusméreteket, amely 12,7 $\pm 2,1$; 26,4 \pm 3,9 és 94,8 \pm 9,4 nm volt rendre az NC-13, NC-27 és NC-90 mintáknál, tükrözve a szilika templát részecskék méretét. Ezzel szemben a nempórusos NC katalizátor szerkezetében a TEM felvételek alapján nem voltak láthatók mezo- vagy makropórusok. A nagyfelbontású transzmissziós elektronmikroszkópos felvételeken (HR-TEM) mind a négy minta esetén hasonló grafitos szerkezetet figyeltünk meg (25. ábra).
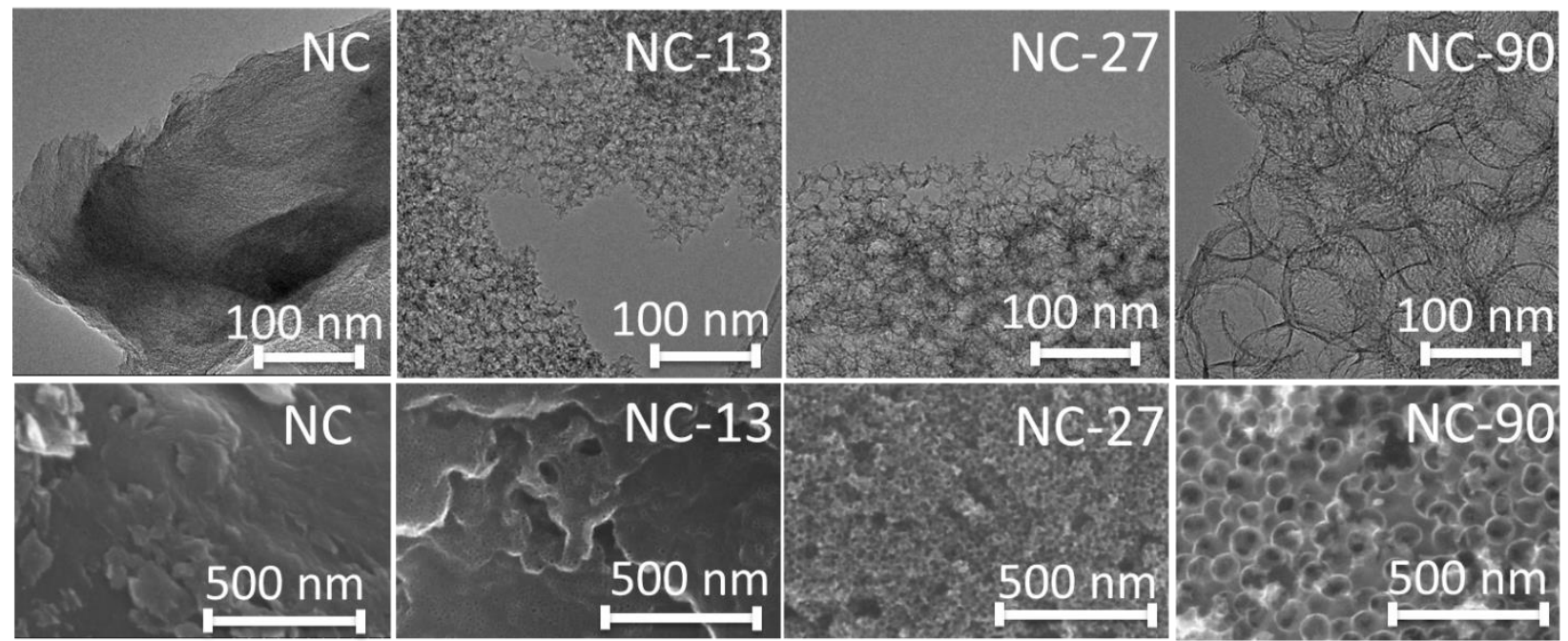

25. ábra: A vizsgált N-C katalizátorok transzmissziós (felső sor) és pásztázó (alsó sor) elektronmikroszkópos felvételei. 


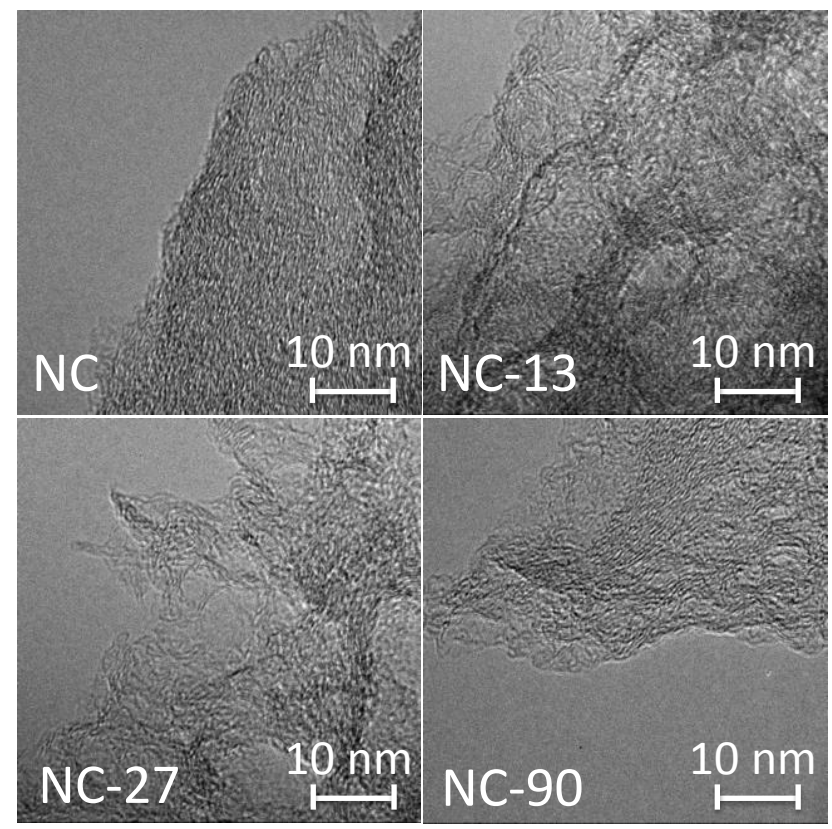

26. ábra: A vizsgált N-C katalizátorok nagyfelbontású TEM képei.

A katalizátorok pórusszerkezetét $\mathrm{N}_{2}$ adszorpciós / deszorpciós izotermák felvételével vizsgáltuk (27. ábra). Az NC-13 és NC-27 minták izotermái (IV. típusú izoterma) a jellegzetes hiszterézissel mezopórusos jellegre utalnak. Az NC-90 izotermáján a kevésbé kifejezett kapilláris kondenzáció, mely ráadásul nagyobb relatív nyomások felé tolódott, inkább a makropórusos anyagok jellemzője. A Barrett-Joyner-Halenda (BJH) módszerrel számított pórusméret eloszlás görbék maximuma 13 (NC-13), 30 (NC-27) és 78 nm-nél (NC-90) jelent meg, összhangban a TEM felvételekből meghatározott pórusmérettel. (A BJH módszer szigorúan csak a mezopórusok tartományában használandó, valószínüleg emiatt volt jelentősebb eltérés az NC-90 minta esetén a TEM felvételekből meghatározott átlagos pórusmérethez képest.) A fajlagos (BET) felület $957 \mathrm{~m}^{2} \mathrm{~g}^{-1}$ volt az NC-13, $899 \mathrm{~m}^{2} \mathrm{~g}^{-1}$ az NC-27, $665 \mathrm{~m}^{2} \mathrm{~g}^{-1} \mathrm{az}$ NC-90, míg mindössze $104 \mathrm{~m}^{2} \mathrm{~g}^{-1}$ a nempórusos NC katalizátor esetén. 

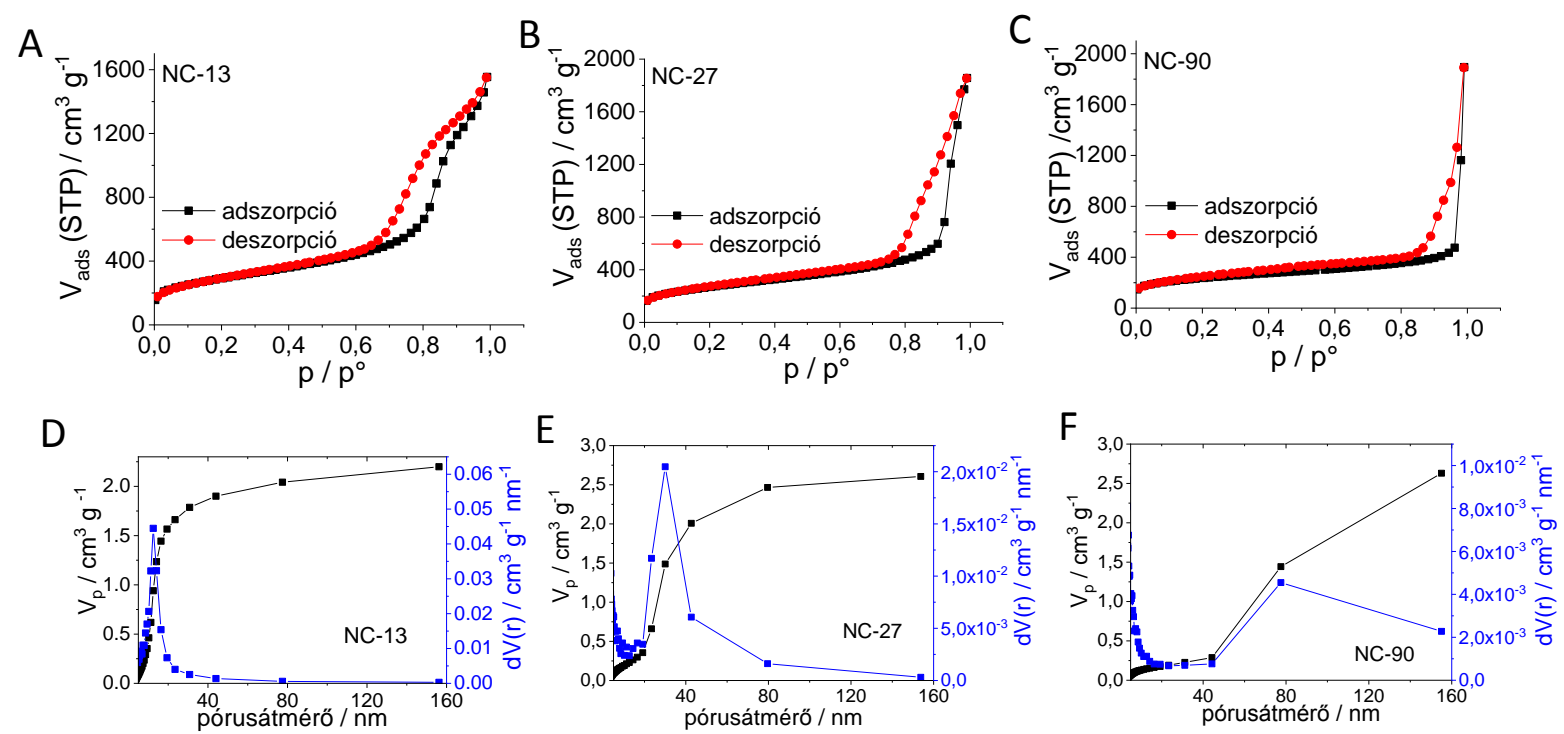

\section{7. ábra: A pórusos $\mathbf{N}-\mathrm{C}$ katalizátorok $\mathrm{N}_{2}$ adszorpciós / deszorpciós izotermái (A-C) és azokból a BJH módszerrel számított pórusméret-eloszlás görbék (D-F).}

A katalizátorokból porlasztva fújással készített elektródok $\left(1,00 \pm 0,07 \mathrm{mg} \mathrm{cm}^{-2}\right.$ borítottság) elektrokémiailag aktív felületét (relatív érdességét) ciklikus voltammetriával határoztuk meg. Példaként a 28. A ábrán az NC-27 elektród ciklikus voltammogramjait mutatom be. A kettősréteg feltöltéséhez és kisütéséhez rendelhető áramokat a pásztázási sebességek függvényében ábrázoltuk és a pontokra illesztett egyenes meredekségéből számítottuk a kettősréteg kapacitás értékeket, melyek az elektrokémiai felülettel egyenesen arányosak (28. B ábra). Összehasonlításként egy sima felületü (polírozott) üvegszén elektródot használtunk azonos $\left(1 \mathrm{~cm}^{2}\right)$ geometriai felülettel, melynek érdességét egységnyinek vettük. A katalizátor rétegek relatív érdesség értékei és BET-felületük között lineáris összefüggést állt fent (28. C ábra). 

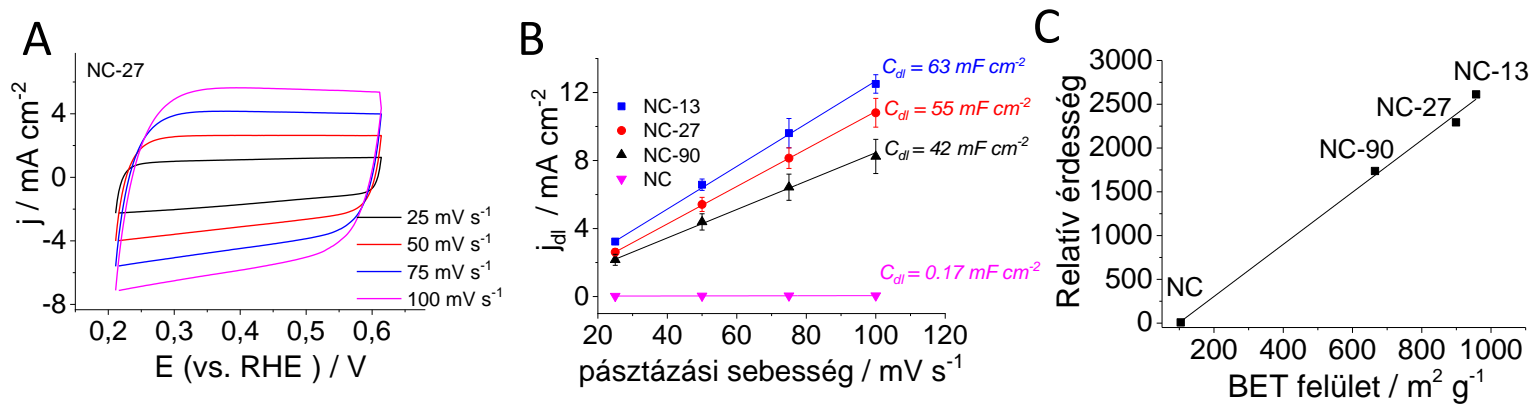

28. ábra: (A): Az NC-27 elektród (1,00 $\mathrm{mg} \mathrm{cm}^{-2}$ borítottság) ciklikus voltammogramjai különböző pásztázási sebességekkel Ar-nal buborékoltatott $1 \mathrm{M} \mathrm{Na}_{2} \mathrm{SO}_{4}$ oldatban. (B): A vizsgált $\mathrm{N}-\mathrm{C}$ elektródok ciklikus voltammogramjaiból meghatározott kettősréteg áramok pásztázási sebességtől való függése és az illesztett egyenesek meredekségéből meghatározott kettősréteg kapacitás értékek. (C): Összefüggés a katalizátor rétegek relatív érdessége és a BET-felületük között.

A katalizátorok szén-szerkezetét Raman-spektroszkópiával és röntgendiffrakció mérésével vizsgáltuk (29. ábra). A Raman-spektrumokon látható D $\left(1353 \mathrm{~cm}^{-1}\right)$ és $\mathrm{G}\left(1586 \mathrm{~cm}^{-}\right.$ $\left.{ }^{1}\right)$ sávok a szén vázban lévő hibahelyekről és a grafitosság mértékéről nyújtanak információt. A két sáv intenzitás aránya $\left(I_{D} / I_{G}\right)$ mind a négy katalizátor esetén $0,89 \pm 0,01$ volt, függetlenül a pórusmérettől, ami azonos mennyiségủ hibahely jelenlétére utal. A röntgendiffraktogramokon a $2 \Theta=25^{\circ}$ és $43^{\circ}$ értékeknél megjelenő széles reflexiók, melyek a grafit (002) és (100) indexü rácssíkjaihoz rendelhetők, az amorf szerkezetủ szenekre jellemzők.
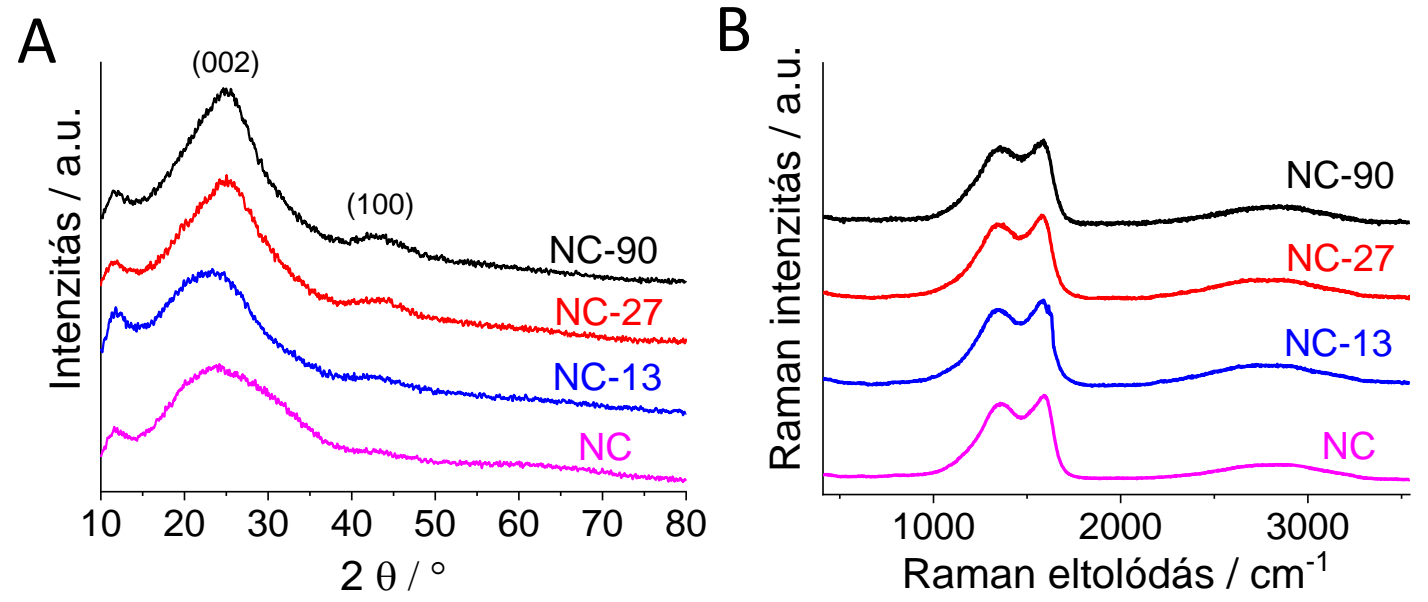

29. ábra: A különböző porozitású N-C katalizátorok röntgendiffraktogramjai (A) és Raman-spektrumai (B).

A katalizátorok felületének kémiai összetételét XPS mérésekkel vizsgáltuk. Az áttekintő spektrumokon szén, nitrogén és oxigén jelét figyelhettük meg, kis mennyiségü kén ( $<1$ atom\%) szennyezés mellet. A vizsgált katalizátorok elemi összetétele nagyon hasonló volt: 80-85\% szenet, 6-8\% N-t és 6-11\% O-t tartalmaztak (4. táblázat). 
4. táblázat: Az N-C katalizátorok XPS mérésekből meghatározott elemi összetétele relatív atomszázalékban.

\begin{tabular}{cccc}
\hline Minta & C / rel.\% & N / rel.\% & O / rel.\% \\
\hline NC & $80,91 \pm 0,36$ & $6,09 \pm 0,07$ & $10,78 \pm 0,60$ \\
NC-13 & $83,26 \pm 0,15$ & $8,43 \pm 0,54$ & $7,83 \pm 0,38$ \\
NC-27 & $83,57 \pm 0,16$ & $8,16 \pm 0,07$ & $7,66 \pm 0,24$ \\
NC-90 & $84,89 \pm 0,52$ & $7,95 \pm 0,46$ & $6,20 \pm 0,89$ \\
\hline
\end{tabular}

A

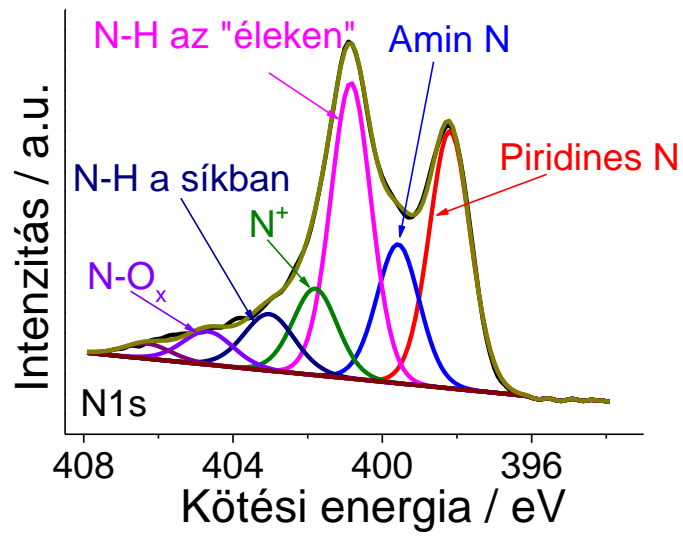

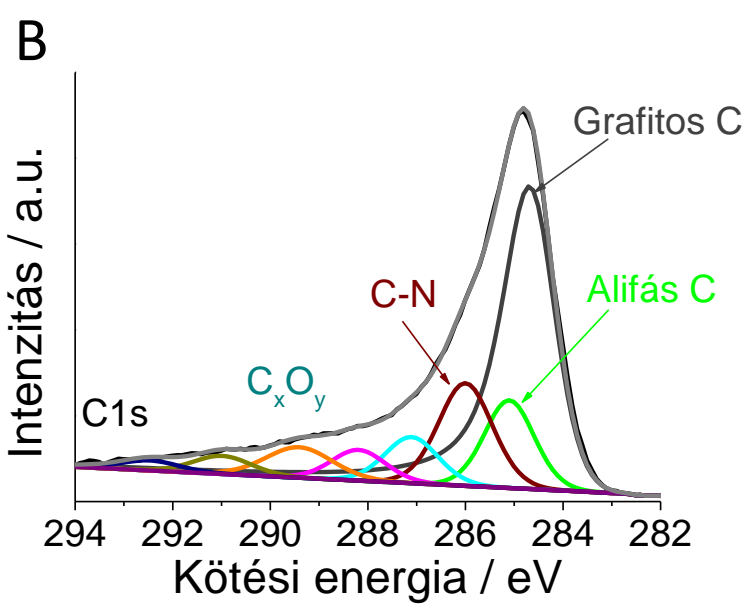

30. ábra: Az NC-90 katalizátor nagy felbontású N1s (A) és C1s (B) XPS spektrumai.

A szén- és nitrogénatomok típusának (kémiai környezet) vizsgálata érdekében a nagyfelbontású $\mathrm{C} 1 \mathrm{~s}$ és $\mathrm{N} 1 \mathrm{~s}$ spektrumokat is felvettük (30. ábra). Az N1s spektrum felbontásával (30. A ábra) öt különbözö kémiai környezetü N-atomot azonosítottunk (piridines $\mathrm{N}$, amin $\mathrm{N}, \mathrm{N}-\mathrm{H}$, grafitos $\mathrm{N} / \mathrm{N}^{+}$és oxidált $\mathrm{N}$ ), melyek relatív mennyisége (31. A ábra) közel azonos volt a különböző pórusméretű minták esetén. A C1s spektrumok alapján a nempórusos NC mintában a grafitos szén aránya nagyobb volt a pórusos mintákhoz képest (31. B ábra). Ennek valószínüsíthető oka, hogy egy sima felületü szén kisebb arányban tartalmaz éleket és hibahelyeket, mint a görbült felületek (pórusos minták). A pórusos minták között azonban nem láttunk lényeges különbséget a különböző kémiai környezetü szénatomok eloszlásában. 

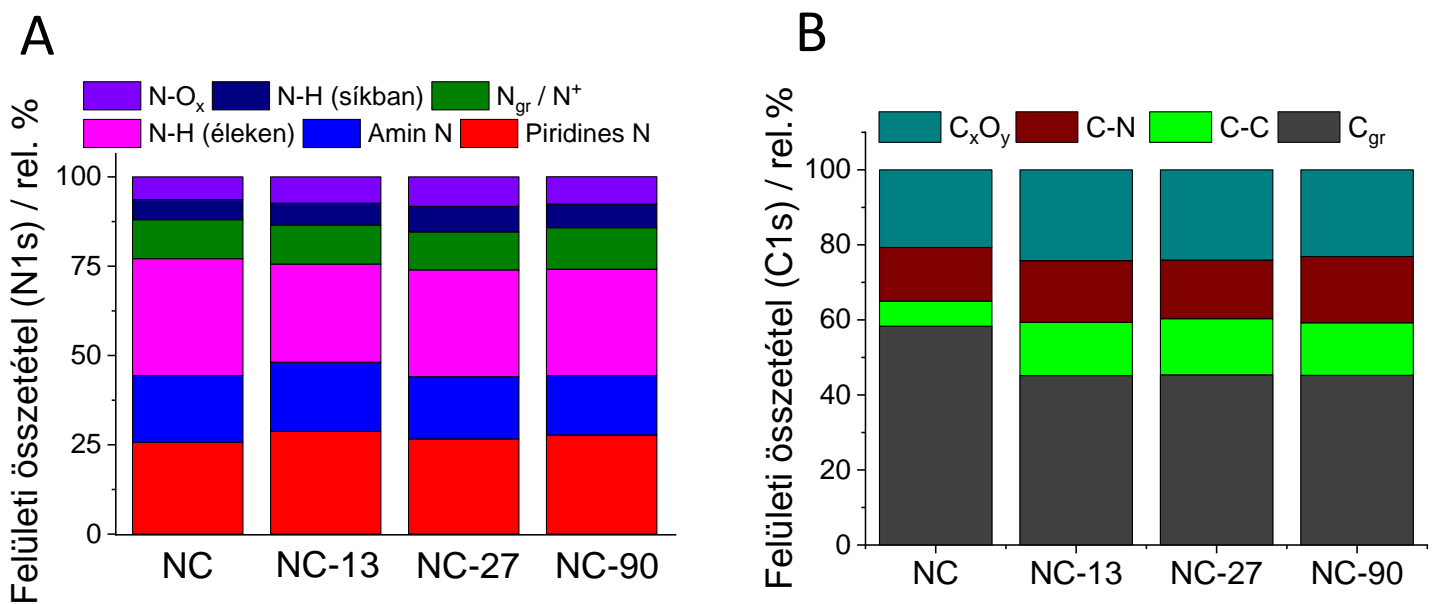

31. ábra: A vizsgált N-C katalizátorok különböző kémiai környezetű N- (A) és C- (B) atomjainak aránya.

Összességében elmondhatjuk, hogy a vizsgált N-C katalizátorok nagyon hasonlóak voltak mind szerkezetük (grafitosság mértéke, hibahelyek száma), mind pedig kémiai tulajdonságaik (felületi csoportok) tekintetében. Ezáltal lehetőséget nyújtottak a morfológiai tényezők szisztematikus vizsgálatára a $\mathrm{CO}_{2}$ redukcióban, egyéb paraméterek állandósága mellett.

\subsubsection{Az elektródok szén-dioxid redukciós tulajdonságai}

Az üvegszén hordozóra felvitt $\mathrm{N}-\mathrm{C}$ katalizátorok $\left(1,00 \pm 0,07 \mathrm{mg} \mathrm{cm}^{-2}\right.$ borítottság) $\mathrm{CO}_{2}$ redukciós aktivitását először lineáris voltammetriával vizsgáltuk $\mathrm{CO}_{2}$-dal telített $0,5 \mathrm{M} \mathrm{KHCO}_{3}$ oldatban (32. ábra). A legnagyobb áramsürüségeket az NC-27 és az NC-13 minták esetén tapasztaltuk, melyek -1,0 V-on meghaladták a $-25 \mathrm{~mA} \mathrm{~cm}{ }^{-2}$-t. Az NC-90 elektród esetén az áramsürüség ennek körülbelül fele volt, míg a nempórusos $\mathrm{NC}$ katalizátoron $-5 \mathrm{~mA} \mathrm{~cm}{ }^{-2}$ alatt maradt a vizsgált potenciáltartományon. A redukciós áram $\left(\mathrm{CO}_{2}\right.$ redukcióhoz és a $\mathrm{H}_{2}$ fejlődéshez köthető Faraday-áram) indulásának potenciálját elsősorban a katalizátorok kémiai tulajdonságai határozzák meg (funkciós csoportok). Ez a potenciál, melyet a lineáris voltammogramok potenciál szerinti derivált görbéiből határoztunk meg (31. C ábra), mind a négy elektród esetén $-0,27 \pm 0,03 \mathrm{~V}$ volt. Ez megerősíti a korábbi megállapításunkat, miszerint az aktív centrumok azonosak a vizsgált katalizátorok esetén. 

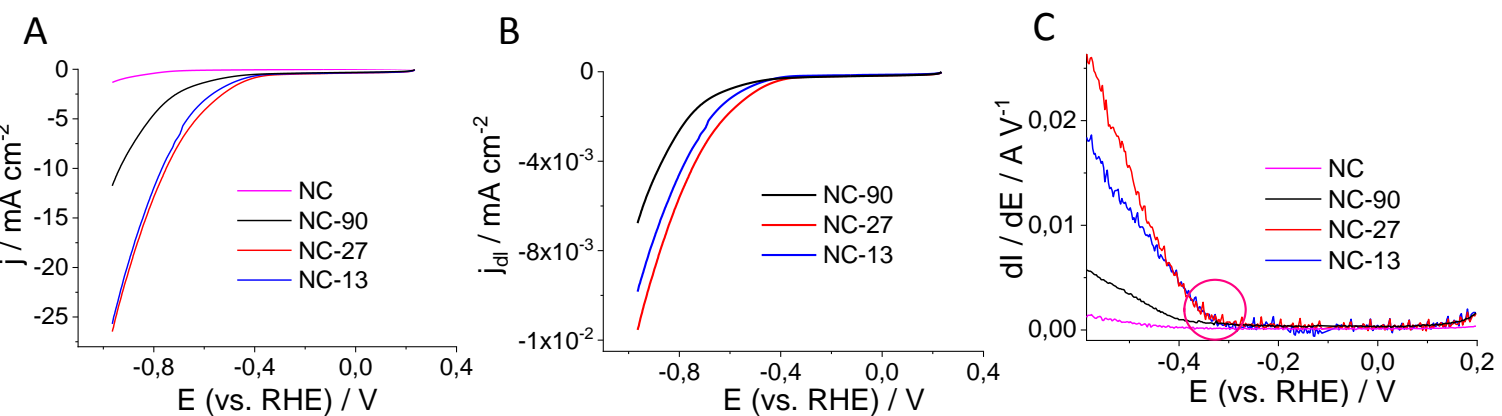

32. ábra: (A): Az N-C elektródok $\mathrm{k}$ lineáris voltammogramjai $\mathrm{CO}_{2}$-dal telített $0,5 \mathrm{M} \mathrm{KHCO}_{3}$ oldatban 5 $\mathrm{mV} \mathrm{s}^{-1}$ pásztázási sebességgel. Az áramsürüségek az elektródok geometriai felületeire vonatkoznak. (B): A pórusos $\mathrm{N}-\mathrm{C}$ elektródok lineáris voltammogramjai, amennyiben az áramokat az elektródok valós elektrokémiai felületeivel normáltuk. (C): A lineáris voltammogramok potenciál szerinti derivált görbéi, melyekből a redukciós áramok indulási potenciáljait határoztuk meg.

Mivel az áramsürüségek az elektrokémiai felülettel arányosak, annak érdekében, hogy ennek a hatását kiküszöböljük, a voltammetriás áramsürüségeket az elektródok relatív érdesség értékeivel is normáltuk (32. B ábra). A pórusos minták között az érdességgel normált áramsürüségek $\left(j_{d l}\right)$ sorrendje ugyanazt a trendet mutatta, mint amit a geometriai felületre vonatkozó áramsürüségek esetén tapasztaltunk. Ez azt jelenti, hogy a katalitikus áramokban tapasztalt különbségekért elsősorban az elektródok szerkezeti különbségei a felelősek, nem pedig az eltérő fajlagos felületek.

$\mathrm{A} \mathrm{CO}_{2}$ redukció szelektivitását a potenciosztatikus elektrolízis során képződő termékek online gázkromatográfiás (gázfázis) és ex situ NMR spektroszkópiás (folyadékfázis) analízisével vizsgáltuk $-0,5 \mathrm{~V}$ és $-0,9 \mathrm{~V}$ (vs. $\mathrm{RHE}$ ) között. Mindegyik minta esetén $\mathrm{CO}$ és $\mathrm{H}_{2}$ fejlődését tapasztaltuk, bizonyos esetekben nyomnyi mennyiségű hangyasav, metanol és metán képződése mellett. Mivel a $\mathrm{CO}$ és a $\mathrm{H}_{2}$ minden esetben az összes képződő termék több, mint 95\%-át tette ki, a továbbiakban csak ezeknek a tárgyalására szorítkozom. A különböző elektródpotenciálokon mért teljes redukciós áramsürüségek a 33. A ábrán láthatók. A teljes áramsürüségekben tapasztalt sorrend a különböző minták esetén megegyezett a lineáris voltammogramok felvétele során tapasztalttal, mind a geometriai felülettel, mind pedig a relatív érdesség értékekkel való normálás esetén. 

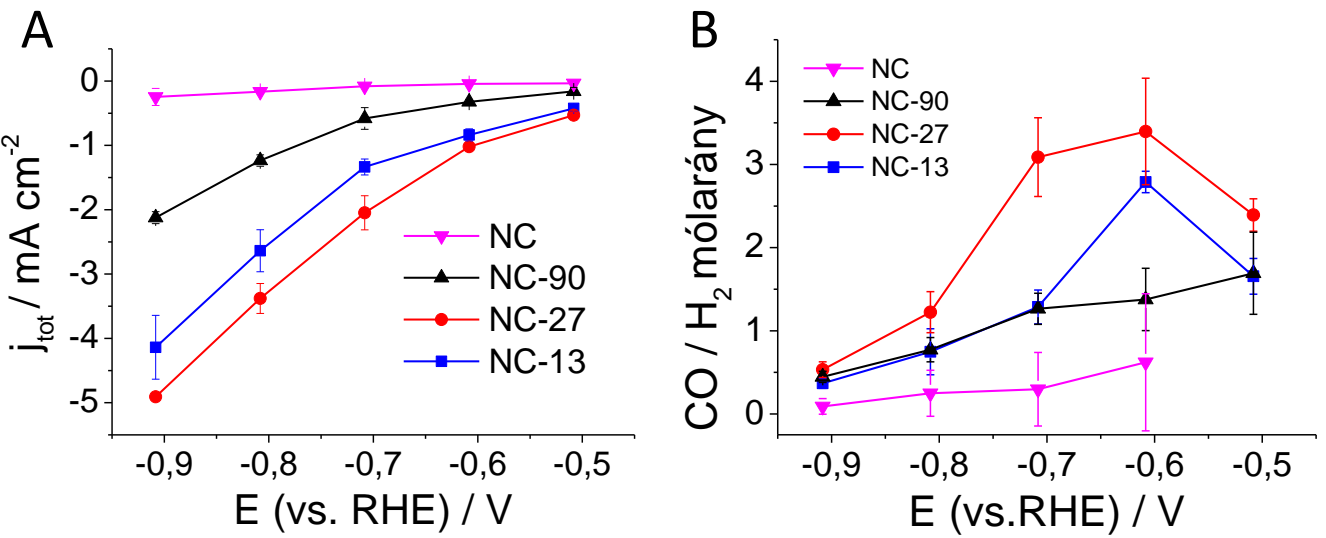

33. ábra: (A) A potenciosztatikus elektrolízisek 40. percében mért teljes redukciós áramsürüségek $\mathrm{CO}_{2}$-dal telített 0,1 M KHCO 3 oldatban. (B) A moláris $\mathrm{CO} / \mathrm{H}_{2}$ arány a különböző pórusméretű katalizátorok esetén a potenciosztatikus elektrolízisek 40. percében.

Ami talán a mért áramok nagyságbeli különbségénél is fontosabb, hogy a redukciós áramsürüségek mellett a szelektivitást is nagymértékben befolyásolta a pórusméret változtatása (33. B ábra). Az NC-13 és az $\mathrm{NC}-27$ minták esetén a $\mathrm{CO} / \mathrm{H}_{2}$ aránynak -0,6 V-on maximuma volt, míg az NC-90 és a nempórusos NC katalizátornál a vizsgált tartományon a túlfeszültség növelésével ez folyamatosan csökkent. Összességében elmondhatjuk, hogy a kisebb pórusok esetén (13 és $27 \mathrm{~nm}$ ) a nagyobb áramsürüségek nagyobb CO-szelektivitással jártak együtt. A termékeloszlásban látott különbségek azonban kisebb túlfeszültségeken voltak kifejezettebbek, amikor a $\mathrm{CO}_{2}$ redukció dominált a hidrogénfejlödéssel szemben $\left(\mathrm{E}<-0,8 \mathrm{~V} ; \mathrm{CO} / \mathrm{H}_{2}>1\right)$. A legnagyobb CO-szelektivitást az NC-27 minta mutatta $-0,6 \mathrm{~V}$ potenciálon 76 \%-os Faradayhatásfokkal. 

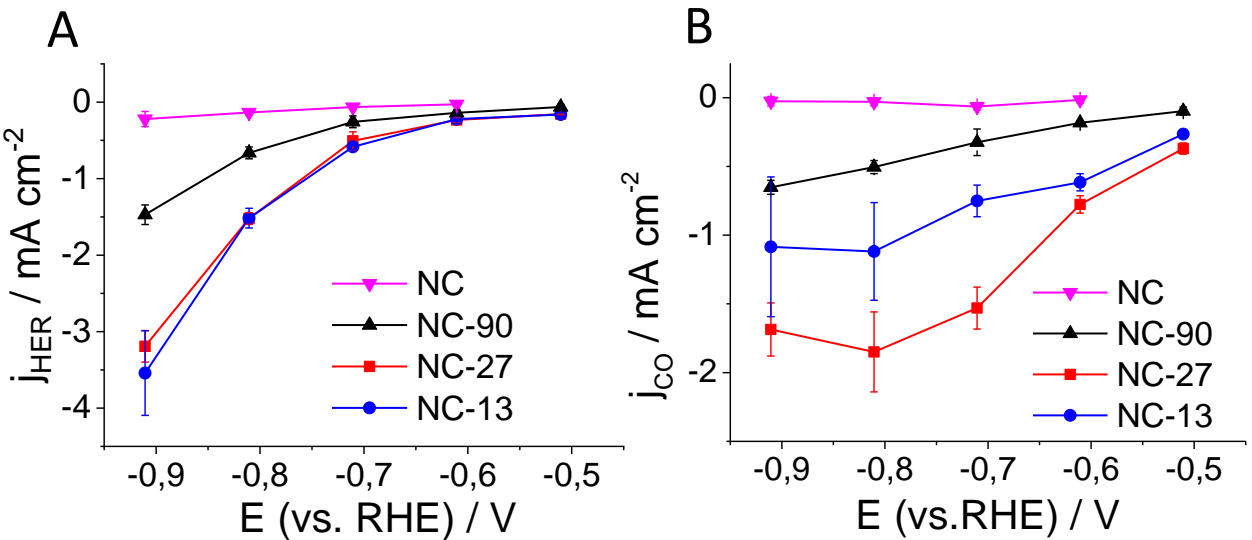

34. ábra: Az N-C katalizátorok hidrogénfejlődésre (A) és CO-fejlődésre vonatkozó parciális áramsürüségei a potenciosztatikus elektrolízisek 40. percében $0,1 \mathrm{M} \mathrm{KHCO}_{3} / \mathrm{CO}_{2}$ elektrolitban. $\mathrm{Az}$ áramsürüségek a geometriai felületre vonatkoznak.

Az elektrokatalitikus folyamatoknak gyakorlati szempontból igen fontos jellemzője a parciális áramsürüség is a szelektivitás mellett, hiszen ez nyújt információt a termékek képződési sebességéről. A $\mathrm{H}_{2}$ és a $\mathrm{CO}$ képződésének parciális áramsürüségei $\left(j_{H E R}, j_{C O}\right)$ a 34. ábrán láthatók. A hidrogénfejlődés parciális áramsürüsége mind a négy elektród esetén exponenciálisan növekedett a növekvő túlfeszültséggel, ami tisztán aktiváció kontrollált folyamatra utal. A jHER az NC-27 és az NC-13 elektród esetén gyakorlatilag megegyezett, míg az NC-90 minta esetén ehhez képest mintegy 2-3-szor kisebb volt. A CO fejlődésére vonatkozó parciális áramok az NC < NC-90 < NC-13 < NC-27 sorrendben növekedtek és a különbözö porozitású minták esetén eltérő potenciálfüggést mutattak. Az NC-90 és NC elektródoknál a $j_{C O}$ az egyre negatívabb potenciálokkal növekedett, ezzel szemben a $\mathrm{CO}_{2}$ redukcióban aktívabb NC-13 és NC-27 esetén -0,8 V-ig növekedett, majd kismértékben csökkent. Ez azt sugallja, hogy az NC-13 és NC-27 katalizátoroknál a töltésátlépési folyamaton túl a morfológiától függő egyéb tényezők is szerepet játszanak a $\mathrm{CO}_{2}$ redukcióban.

Összességében a mezopórusos $\mathrm{NC}-27$ elektród mutatkozott legjobbnak a $\mathrm{CO}_{2}$ redukcióban a CO-szelektivitás és parciális áramsürüség tekintetében is. $\mathrm{Az} \mathrm{NC}-13$ esetén hasonló mértékü $\mathrm{H}_{2}$-fejlesztés mellett csökkent a $\mathrm{CO}_{2}$ redukció sebessége, míg az $\mathrm{NC}-90$ esetén a $\mathrm{CO}_{2}$ redukció és a $\mathrm{H}_{2}$-fejlesztés együttesen visszaszorult.

\subsubsection{A katalizátor rétegvastagságának hatása a $\mathrm{CO}_{2}$ redukcióban}

Az előző fejezetben bemutatott kísérletek során a különböző porozitású katalizátorok azonos tömegü rétegeinek $\mathrm{CO}_{2}$ redukciós tulajdonságait hasonlítottam össze. Az eltérő porozitás 
miatt azonban a rétegvastagság kismértékben változhat, annak ellenére is, hogy a katalizátorok szintézise során a teljes pórustérfogatot igyekeztünk állandó értéken tartani az azonos $\mathrm{SiO}_{2} /$ oPD tömegarány által. Annak érdekében, hogy kizárjuk azt, hogy a különböző pórusméretü rétegek nagymértékben eltérő $\mathrm{CO}_{2}$ redukciós aktivitása a rétegvastagság változásából ered, kontroll kísérleteket végeztünk. Ehhez az NC-27 katalizátor három különböző borítottságú (tömegü) rétegének $\mathrm{CO}_{2}$ redukciós aktivitását hasonlítottuk össze (35. ábra).
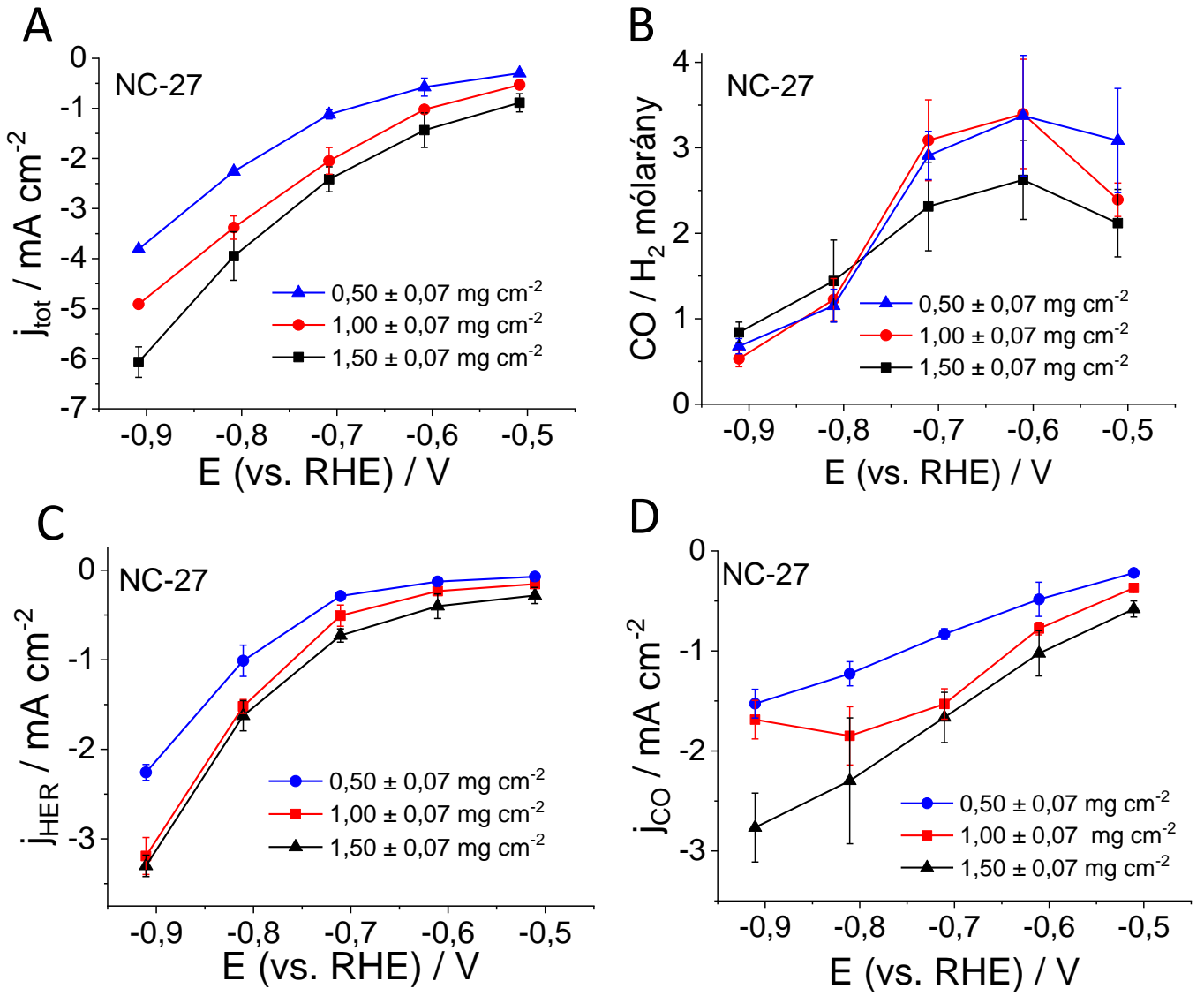

35. ábra: Az NC-27 katalizátor különböző borítottságú rétegeinek $\mathrm{CO}_{2}$ redukciós aktivitása. (A): Teljes áramsürüségek, (B): CO / H2 mólarány, (C): Hidrogénfejlődés parciális áramsürüsége, (D): CO fejlődés parciális áramsűrüsége. Az áramsürüségek a geometriai felületekre vonatkoznak.

A teljes és a parciális áramsürüségek növekedtek a katalizátor növekvő tömegével, azonban a fajlagos aktivitás (relatív érdességgel osztott áramsürüség) a rétegvastagság növelésével csökkent. Ennek lehetséges oka, hogy a vastagabb rétegek anyagtranszporttal szembeni ellenállása nagyobb. A keletkező $\mathrm{CO}$ és $\mathrm{H}_{2}$ mólaránya hasonló volt a $0,50 \mathrm{mg} \mathrm{cm}^{-2}$ és az $1,00 \mathrm{mg} \mathrm{cm}^{-2}$ tömegủ rétegek esetén minden vizsgált elektródpotenciálon. A legvastagabb 
rétegnél (1,50 $\left.\mathrm{mg} \mathrm{cm}^{-2}\right)$ azonban a $\mathrm{CO} / \mathrm{H}_{2}$ arány körülbelül $30 \%$-kal visszaesett a -0,7 V-nál nagyobb potenciálokon, ahol a CO a domináns termék.

Ezek a kísérletek azt mutatták, hogy a rétegvastagság viszonylag nagymértékü változtatása (két- és háromszoros tömegnövekedés) csupán kismértékü változást okozott a termékeloszlásban, ami messze elmaradt a pórusméret hatásától. Tekintettel arra, hogy a különböző porozitású katalizátor rétegek között nem várható ekkora mértékü különbség a rétegvastagságban, ezt hatást elhanyagolhatónak tekintjük.

\subsubsection{A morfológiától függő $\mathrm{CO}_{2}$ redukciós teljesítmény okai}

Annak érdekében, hogy fényt derítsünk arra, hogy mi állhat a különböző porozitású katalizátorok eltérő $\mathrm{CO}_{2}$ redukciós aktivitása mögött, vizsgáltuk az $\mathrm{N}-\mathrm{C}$ minták nedvesedési tulajdonságait, a redukció során a buborékképződés dinamikáját, valamint a $\mathrm{CO}_{2}$ adszorpciós erősségét.

\subsubsection{A katalizátor rétegek nedvesedési tulajdonságai}

A hatékony $\mathrm{CO}_{2}$ redukcióhoz a katalizátor felületét (a pórusokon belül is) egy vékony elektrolit rétegnek kell borítania a kellő ionvezetés biztosítása érdekében. Ugyanakkor nem kedvező, ha a pórusok teljesen telítődnek az elektrolittal, hiszen ekkor a $\mathrm{CO}_{2}$ transzportja az aktív helyek felé gátolttá válik és a hidrogénfejlődés lesz a domináns reakció. Emiatt a katalizátornak megfelelő nedvesedési tulajdonságokkal kell rendelkeznie. ${ }^{123}$

A katalizátor rétegek hidrofil-hidrofób jellegét dinamikus (haladó és hátráló) peremszögek mérésével tanulmányoztuk, tesztfolyadékként desztillált vizet használva (36. A ábra). A vizsgálandó réteg felületén elhelyezett csepp méretét fokozatosan növelve, majd csökkentve minden egyes csepptérfogatnál mértük a peremszöget $(\Theta)$. A haladó és hátráló peremszögek nem egyeznek meg, a hiszterézis oka többek között a felület kémiai és topológiai heterogenitása, a tesztfolyadék behatolása a pórusokba (nedvesítés) vagy a felületi molekulák átrendeződése lehet. ${ }^{121}$ A peremszög hiszterézisből a réteg látszólagos felületi energiája számítható (36. B ábra). 

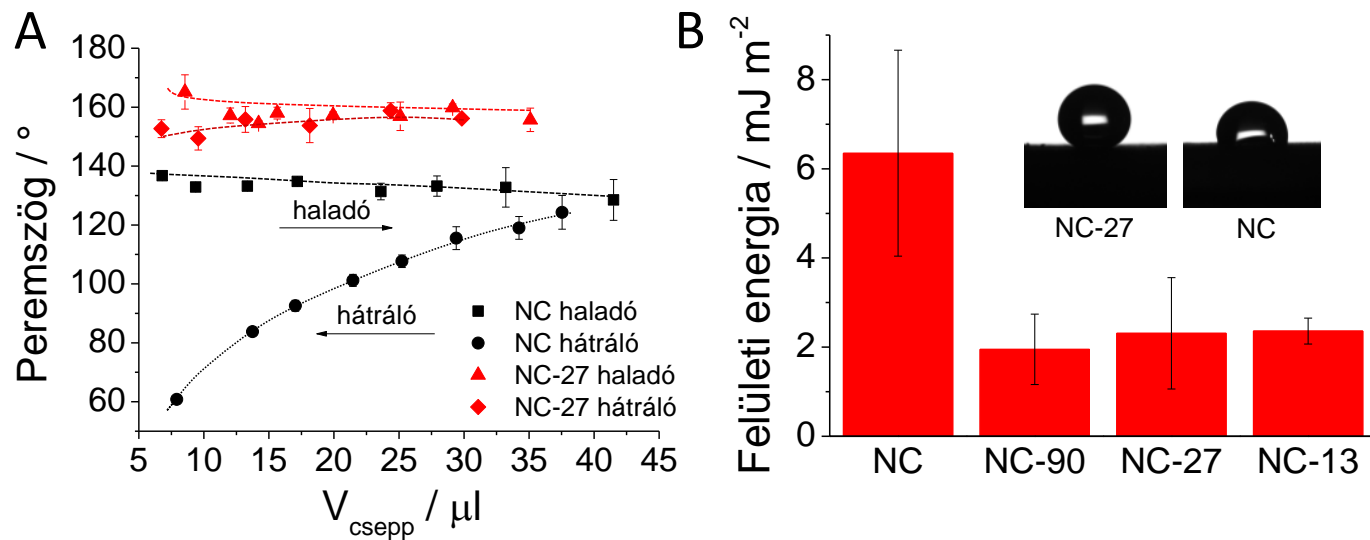

36. ábra: (A): Dinamikus peremszög mérések az NC és az NC-27 katalizátorok esetén. (B): A vizsgált N-C katalizátorok peremszög hiszterézisekből számított látszólagos felületi energiái.

A pórusos katalizátorok szuperhidrofób tulajdonságúak voltak $\left(\Theta>150^{\circ}\right)$ és viszonylag kis hiszterézist mutattak. A számított felületi energia $\left(\gamma_{\mathrm{s}, t o t}\right)$ mindhárom katalizátor réteg esetén kb. $2 \mathrm{~mJ} \mathrm{~m}^{-2}$ volt. A nempórusos NC minta szintén hidrofób jellegü volt, azonban peremszöge kisebb volt $\left(\Theta_{\mathrm{adv}} \sim 130^{\circ} \mathrm{C}\right)$ és jelentös hiszterézist mutatott. Ennek megfelelően nagyobb felületi energiával rendelkezett a pórusos mintákhoz képest $\left(\gamma_{\mathrm{s}, \mathrm{tot}}=6,35 \pm 2,31 \mathrm{~mJ} \mathrm{~m}^{-2}\right)$. A pórusok kialakítása a szén vázban tehát csökkentette a felületi energiát (ideális porozitás), összhangban az ismert morfológia-felületi energia korrelációkkal. ${ }^{124,125}$ A pórusos katalizátorok csökkent felületi energiája (a nempórusos $\mathrm{NC}$ mintához képest) magyarázat lehet a nagyobb $\mathrm{CO}_{2}$ redukciós aktivitásukra azáltal, hogy hidrofóbabb jellegük miatt megakadályozzák a pórusok elektrolittal való telítődését. Ez pedig segíti a $\mathrm{CO}_{2}$ transzportját az aktív helyek felé miközben visszaszorítja a hidrogénfejlődést.

\subsubsection{Gázfejlődés dinamikájának vizsgálata a $\mathrm{CO}_{2}$ redukció során}

Az elektród morfológiája és nedvesedési jellemzői a redukció során képződő gázbuborékok méretét és tartózkodási idejét is befolyásolják. ${ }^{90,126} \mathrm{~A}$ buborékfejlődés konvekciót idéz elő az elektród közelében, ami csökkenti a diffúziós rétegvastagságot és nagyobb katalitikus áramsürüséget eredményezhet (anyagtranszport elősegítése). Ezzel szemben, az elektród felületén hosszabb ideig tartózkodó, nagyobb méretü buborékok időlegesen csökkentik az aktív felületet, ami a katalitikus aktivitás csökkenéséhez vezet. Ezen okok miatt vizsgáltuk az elektrolízis során keletkező gázbuborékok $\left(\mathrm{H}_{2}\right.$ és $\left.\mathrm{CO}\right)$ távozási méretét és tartózkodási idejét egy digitális mikroszkóp segítségével (37. ábra). 


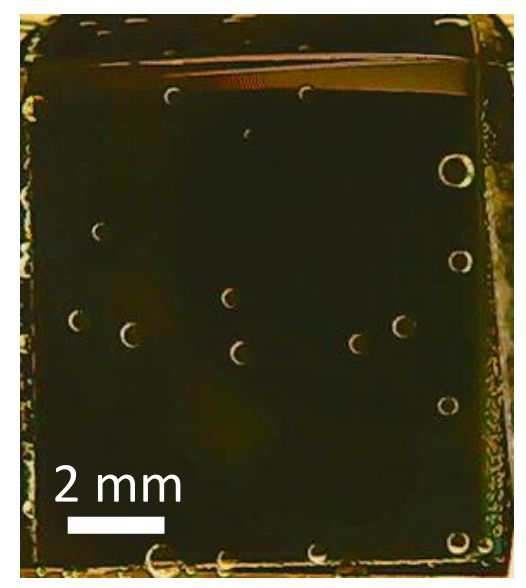

37. ábra: Az NC-27 elektródon potenciosztatikus elektrolízis közben fejlődő buborékok digitális mikroszkópos képe.

A képződő buborékok viszonylag nagyméretüek voltak (néhány száz $\mu \mathrm{m}$ ) feltehetően a katalizátorok hidrofób jellege miatt. A túlfeszültség növelésével a buborékok mérete és tartózkodási ideje is csökkent mind a négy pórusátmérő esetén (NC-27-re bemutatva a 38. A ábrán), nagy valószínüséggel az áramsürüségek növekedése miatt. Adott potenciálon (38. B ábra) a pórusos elektródokon fejlődő buborékok tartózkodási ideje drasztikusan csökkent a nempórusos elektródhoz képest. Továbbá a pórusos mintákat összevetve, a pórusméret csökkentésével a buborékok távozási mérete és tartózkodási ideje egyaránt csökkent. Ez a tapasztalat összhangban van azzal a korábbi megfigyeléssel, miszerint a buborékok nagyobb gyakorisággal távoznak kisebb nanostruktúrák esetén. ${ }^{90}$ Azt is megfigyeltük ezen túl, hogy a buborékméretek és tartózkodási idők polidiszperzitása a pórusméret növelésével nőtt, ami folyamatos nukleációra utal (38. C és D ábra). 


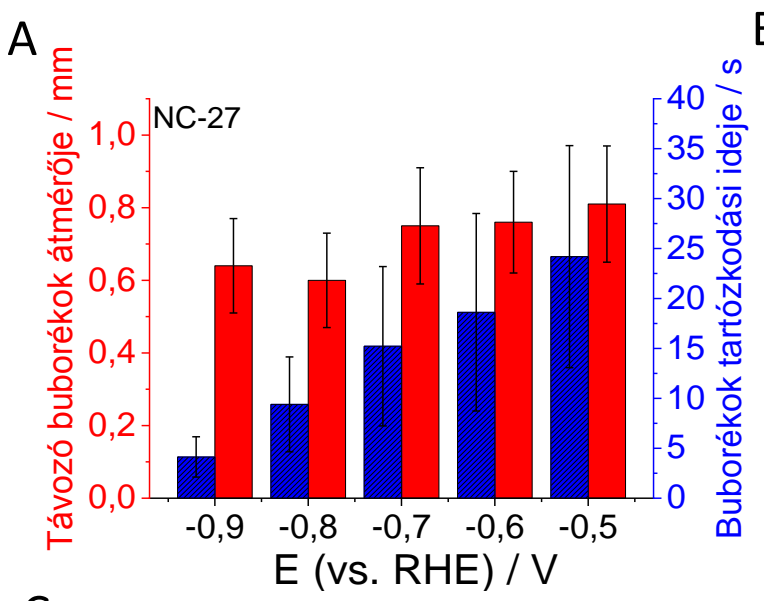

B

C
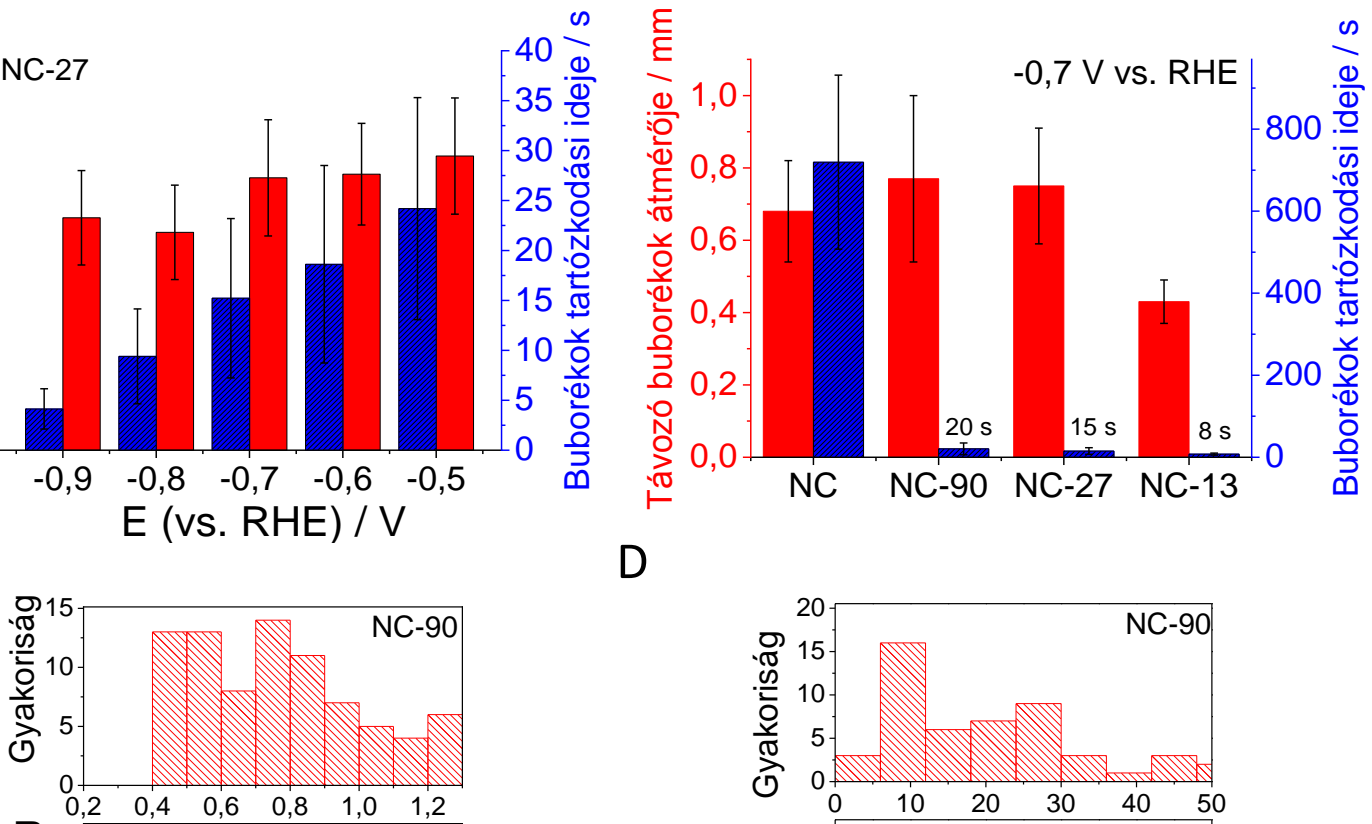

$\mathrm{D}$
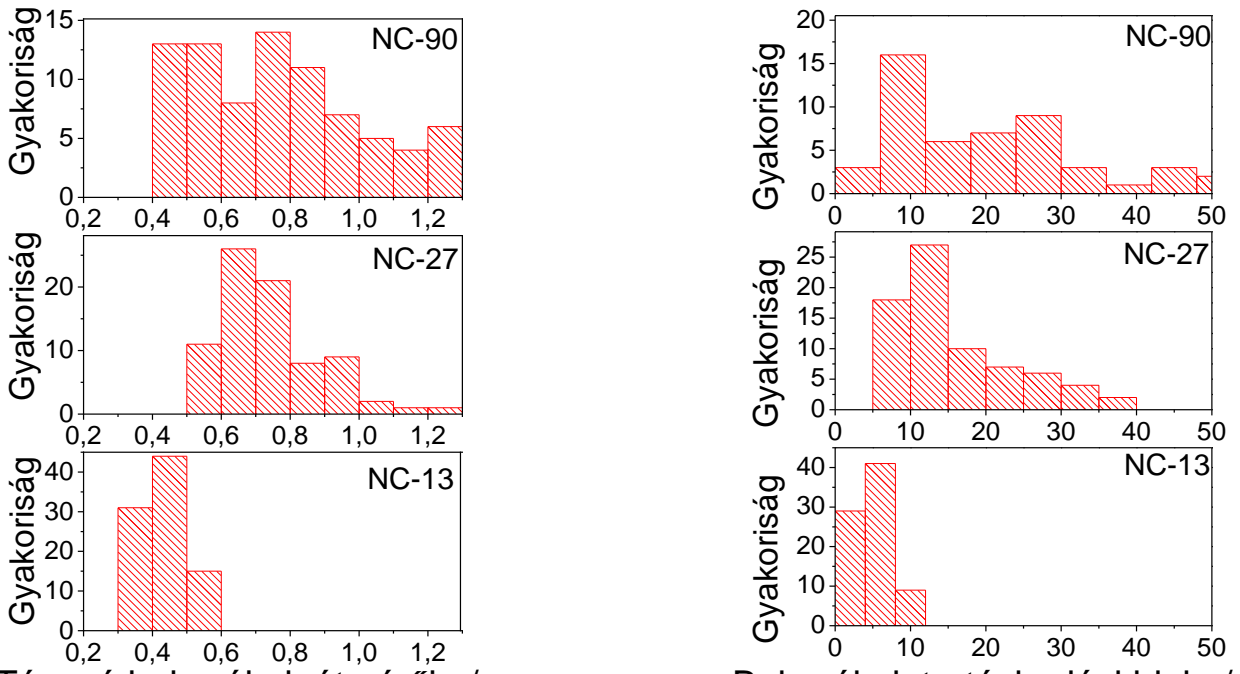

Távozó buborékok átmérője / mm

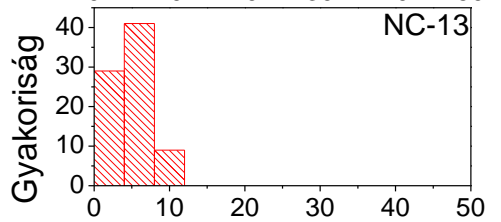

Buborékok tartózkodási ideje / s

38. ábra: Buborékképződés dinamikájának tanulmányozása az $\mathrm{N}-\mathrm{C}$ elektródokon potenciosztatikus elektrolízis közben. (A): A távozó buborékok átmérője és tartózkodási ideje az NC-27 elektródon a potenciál függvényében. (B): A távozó buborékok átmérője és tartózkodási ideje a különböző pórusméretű minták esetén -0,7 V (vs. RHE) potenciálon. (C): A buborékméretek eloszlása a pórusos minták esetén -0,7 V-on (vs. RHE). (D): A buborékok tartózkodási idejének eloszlása a pórusos minták esetén -0,7 V-on (vs. RHE).

A tapasztalt különbségek a buborékfejlődés dinamikájában további magyarázatként szolgáltak a pórusos minták kedvezőbb $\mathrm{CO}_{2}$ redukciós tulajdonságaira a nempórusos $\mathrm{NC}$ katalizátorhoz képest. Ezzel szemben nem adtak választ arra, hogy miért az NC-27 rendelkezik a legnagyobb $\mathrm{CO}_{2}$ redukciós aktivitással, hiszen az $\mathrm{NC}-13$ minta esetén várható a $\mathrm{CO}_{2}$ transzport legnagyobb mértékü elősegítése a buborékképződés által (buborékok legkisebb tartózkodási ideje). 


\subsubsection{A szén-dioxid adszorpciós erősségének vizsgálata}

A reaktánsok és köztitermékek katalizátorfelülethez való kötődésének erőssége fontos

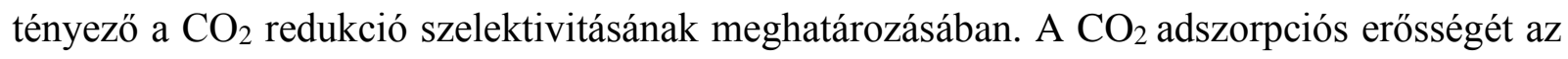
$\mathrm{N}-\mathrm{C}$ katalizátorokon hőmérséklet programozott deszorpcióval (TPD) vizsgáltuk (39. ábra). A nempórusos NC esetén egy deszorpciós csúcsot láttunk $384 \mathrm{~K}$-en. Ezzel szemben a pórusos minták $\mathrm{CO}_{2}$ deszorpciója két lépésben történt. Feltételezzük, hogy az első lépés $(<400 \mathrm{~K})$ a katalizátorok külső felszínén adszorbeálódott $\mathrm{CO}_{2}$ távozásához, míg a második lépés a pórusok belső felszínén kötődő $\mathrm{CO}_{2}$ deszorpciójához (ami nincs jelen a nempórusos NC mintánál) köthető. A második lépés hőmérséklete az NC-27 mintánál volt a legnagyobb (433 K), vagyis ebben az esetben a legerősebb a $\mathrm{CO}_{2}$ kötődése.

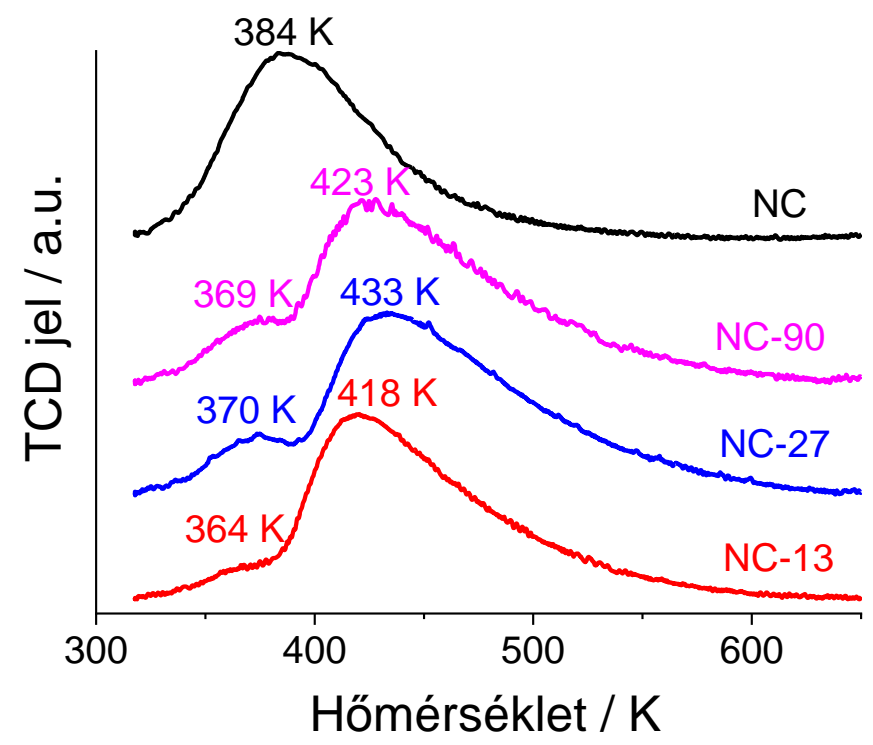

39. ábra: Az N-C katalizátorok hőmérséklet programozott $\mathrm{CO}_{2}$ deszorpciós profiljai.

Figyelembe véve, hogy a vizsgált $\mathrm{N}-\mathrm{C}$ katalizátorok nagyon hasonló N-funkciós csoportokkal rendelkeznek (így feltételezhetően az aktív centrumok is azonosak), a minták eltérő erősségü $\mathrm{CO}_{2}$ adszorpciója nagy valószínüséggel a pórusszerkezet különbözőségéből ered. A különböző görbületü felületek (eltérő méretü pórusok) által az adszorpciós centrumokra gyakorolt erőhatás eltérő lehet (szerkezeti feszültség), ami befolyásolhatja az adszorpciós erősséget. Úgy véljük, hogy ez a kötéserősség a $27 \mathrm{~nm}$ átmérőjü pórusok esetén a legmegfelelöbb a $\mathrm{CO}_{2}$ redukció szempontjából. A $\mathrm{CO}_{2}$ adszorpciós erősségének görbült felületeken való változásának lehetőségét elméleti számítások alapján grafénon és nitrogén- 
adalékolt szeneken is felvetették ${ }^{88,89}$ valamint a különbözö görbületü adszorpciós helyek hatását az oxigén redukciós reakcióban kísérletileg is vizsgálták. ${ }^{127}$

Fontos továbbá, hogy a vizsgált N-C katalizátorok szerkezete nem tökéletes, hanem hibahelyeket tartalmaznak a szénvázban. Az éleken és a sík belsejében található hibák aránya viszont függhet a pórusmérettől, ami a redukciós aktivitás / szelektivitás változását eredményezheti. A kisebb pórusoknál nagyobb arányban várunk éleken található hibákat a síkbeliekhez képest, ami a redukciós aktivitás növekedéséhez vezethet. A C1s XPS spektrumok alapján a nempórusos minta valóban nagyobb arányban tartalmazott grafitos szénatomot a pórusos katalizátorokhoz képest, valószínúleg a kisebb számú hibahely (élek) miatt. A nagyobb görbület (kisebb pórusátmérö) ezen kívül a lokális elektromos tér változása által a $\mathrm{CO}_{2}$ koncentrációjának lokális növekedését is okozhatja az aktív helyek környezetében. ${ }^{87}$ Ez egy további oka lehet az NC-13 és az $\mathrm{NC}-27$ kedvezőbb $\mathrm{CO}_{2}$ redukciós tulajdonságának.

\subsubsection{A szén-dioxid redukciós aktivitás - szelektivitás - stabilitás közötti összefüggések}

A katalitikus aktivitás és szelektivitás mellett a stabilitás a harmadik kulcsparaméter, amit katalizátorfejlesztés során szem elött kell tartanunk. Müködés közben a nanoszerkezetü katalizátorok morfológiája változhat, ami együtt járhat a katalitikus teljesítmény változásával. ${ }^{94}$ Ennek tükrében tanulmányozni kívántuk az N-C katalizátorok stabilitását meghatározó legfőbb tényezőket.

A rövidtávú müködés (70 min) során tapasztalt áramcsökkenést az elektródpotenciál, a parciális áramsürüségek és a szelektivitás $\left(\mathrm{CO} / \mathrm{H}_{2}\right)$ függvényében is vizsgáltuk. Érdekes módon $\mathrm{a}_{2}$ redukciós áram stabilitása (a 70. és a 15 . percben mért $\mathrm{CO}$ parciális áram aránya) a $\mathrm{CO}$ fejlődés sebességével $\left(j_{C O}\right)$ növekedett (40. A ábra). A pórusmérettől függetlenül a pontok ugyanarra a trendvonalra illeszkedtek, a különböző minták stabilitásának sorrendje a $\mathrm{CO}_{2}$ redukciós aktivitásuk sorrendjét követte. Ugyanezen adatok másféle megjelenítése látható a 40. B ábrán a legaktívabb NC-27 példáján. Ezzel az ábrázolásmóddal is szembetünő, hogy a $\mathrm{CO}_{2}$ redukciós stabilitás összefügg az aktivitással.

A szelektivitás és a stabilitás közötti összefüggésre is kíváncsiak voltunk, ezért a CO / $\mathrm{H}_{2}$ mólarány függvényében is ábrázoltuk a $\mathrm{CO}$ parciális áramának a stabilitását. Példakánt az NC-27-re mutatom be ezeket az eredményeket (40. C ábra). A stabilitás ez esetben a COszelektivitás csökkenésével növekedett, ami azt jelenti, hogy kompromisszum szükséges a két 
paraméter tekintetében. Ugyanezt a stabilitásvizsgálatot a $\mathrm{H}_{2}$ áramok esetében is elvégeztük, azonban ekkor nem fedeztünk fel hasonló egyértelmü korrelációkat (40. D-F ábrák). Ráadásul

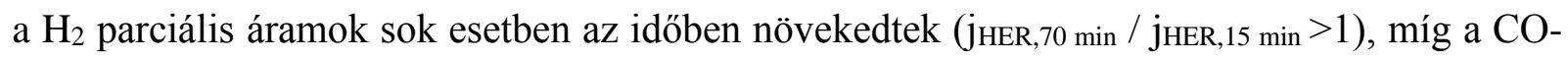
áramok minden esetben csökkentek.
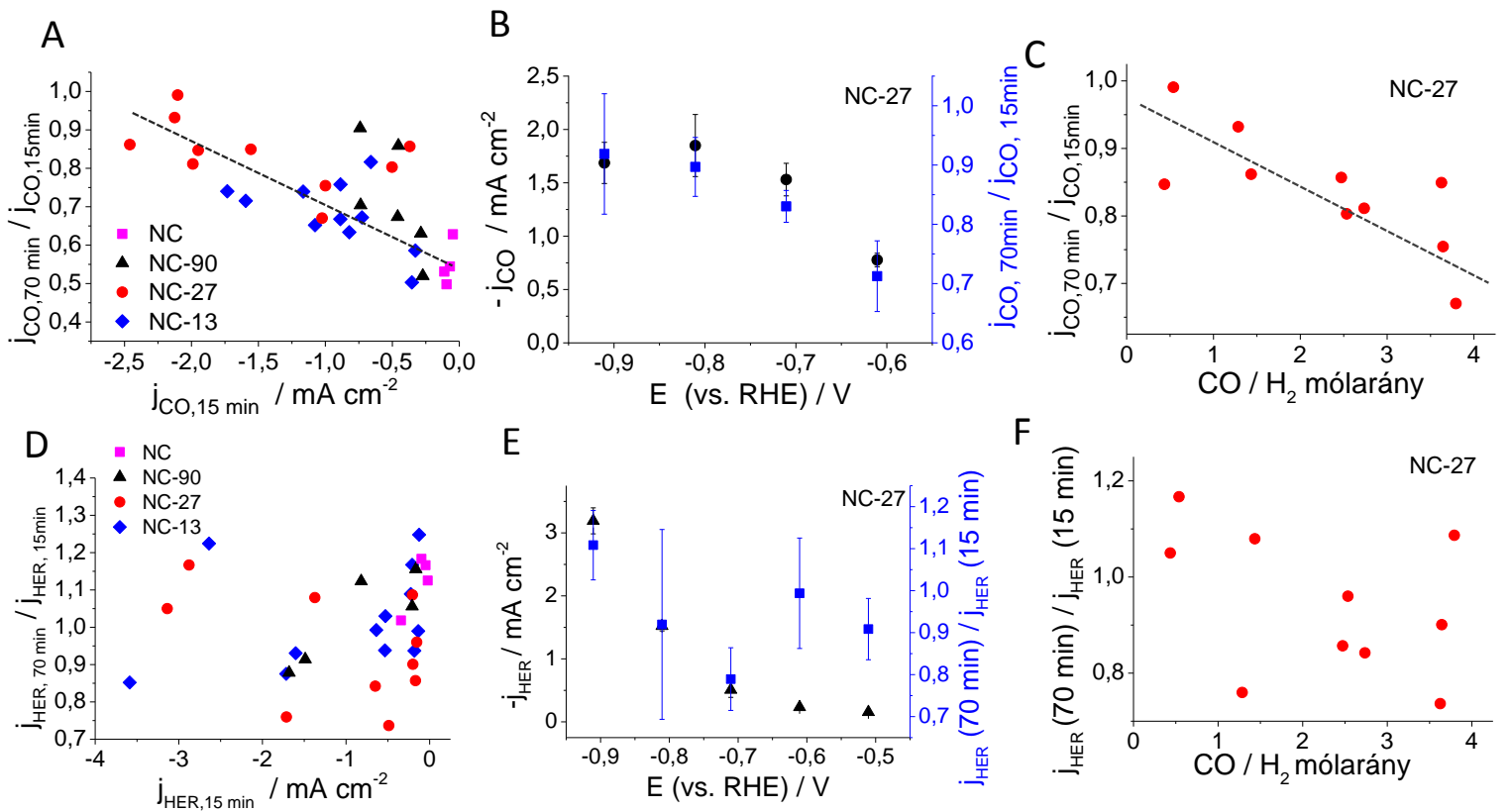

40. ábra: Az N-C elektródok rövidtávú stabilitásának vizsgálata. (A): A CO-fejlődés parciális áramának stabilitása a CO parciális áram függvényében. (B): A CO-fejlődés parciális árama és annak stabilitása az elektródpotenciál függvényében. (C): A CO-fejlődés parciális áramának stabilitása a $\mathrm{CO} / \mathrm{H}_{2}$ mólarány függvényében. (D): A H2-fejlődés parciális áramának stabilitása a $H_{2}$ parciális áram függvényében. (E): A $H_{2}$ parciális áram és annak stabilitása az elektródpotenciál függvényében. (F): a $\mathbf{H}_{2}$-fejlödés parciális áramának stabilitása a $\mathrm{CO} / \mathrm{H}_{2}$ mólarány függvényében függvényében.

Összefoglalva, a $\mathrm{CO}_{2}$ redukciós áramok stabilitása a $\mathrm{CO}$-fejlődés sebességének növekedésével és a CO-szelektivitás csökkenésével nött. Azonban, hogy kiderítsük mi állhat a hátterében ennek a látszólag ellentmondásos tapasztalatnak (irreverzibilis változás az aktív centrumokban, az aktív centrumok környezetét érintő morfológiai változások, stb.), további vizsgálatok szükségesek.

Végül az NC-27 elektród középtávú morfológiai és aktivitásbeli stabilitását is vizsgáltuk -0,6 V-on, ahol a legnagyobb CO-szelektivitást figyeltük meg (41. ábra). Az első két órában a redukciós áram csökkenése $27 \%$-os volt, ezt követően azonban a negyedik óra végéig az áram már csak 14\%-kal esett vissza (41. C ábra). Ez az aktivitás csökkenés elsősorban a CO parciális áram visszaeséséhez volt köthető, összhangban a fenti stabilitás-szelektivitás korrelációval. A négyórás potenciosztatikus elektrolízist követően a katalizátor 
pórusszerkezetében azonban nem láttunk jelentős változást (40. A és B ábrák), vagyis a morfológia a mezopórusok tartományában stabilnak mondható.
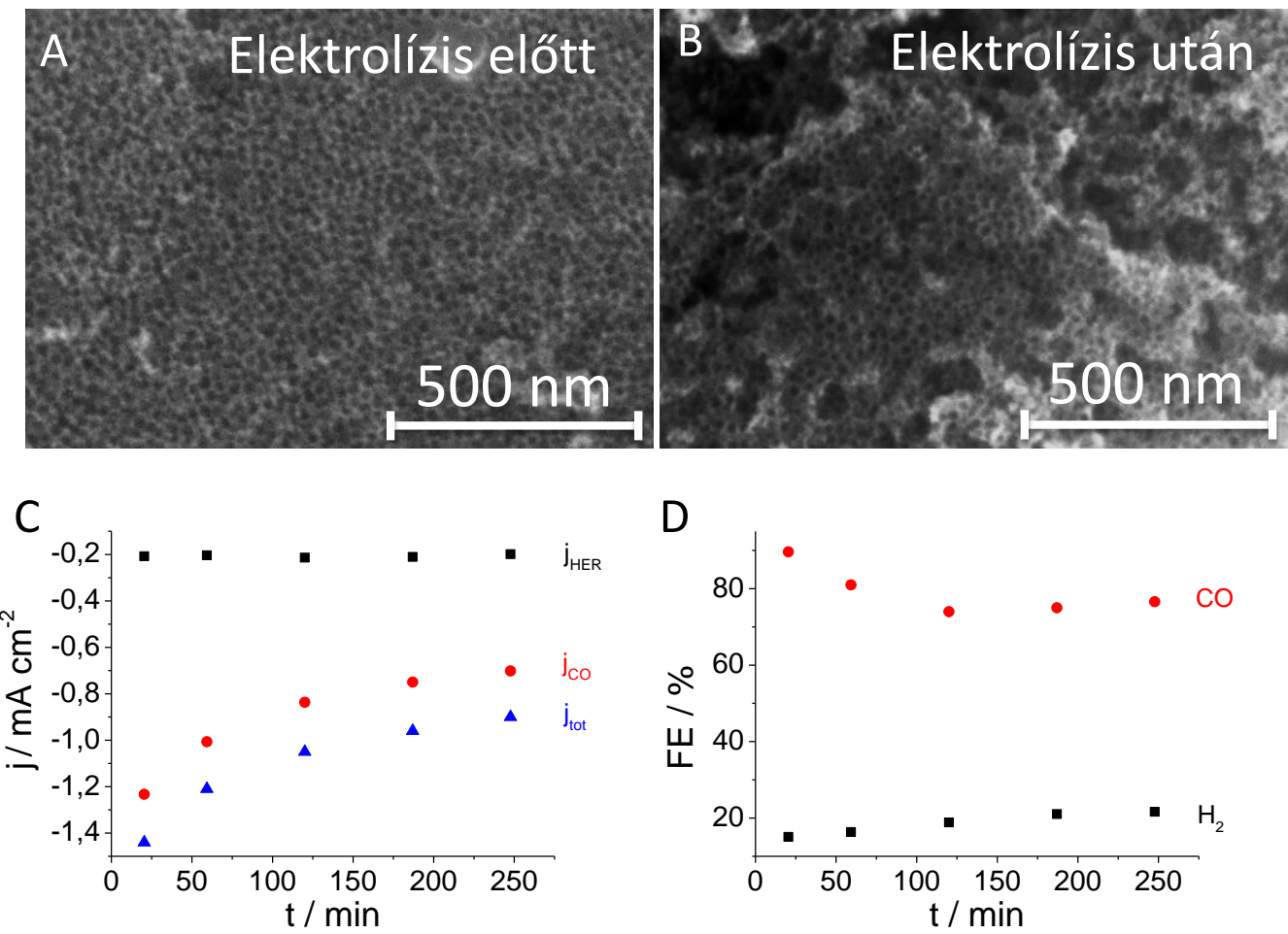

41. ábra: Az NC-27 elektród SEM felvételei $-0,6 \mathrm{~V}$ potenciálon végzett négy órás elektrolízis elött $(\mathrm{A})$ és után (B). Az átlagos pórusméret elektrolízis előtt 20,4 $\pm 3,2 \mathrm{~nm}$, míg elektrolízis után 22,7 $\pm 3,9 \mathrm{~nm}$ volt. A teljes és parciális áramok (C), valamint a CO- és a $\mathrm{H}_{2}$-fejlödés Faraday-hatásfokai (D) -0,6 V-on $\mathrm{CO}_{2}$-dal telített 0,1 M KHCO3 oldatban a négyórás elektrolízis során. 


\subsection{Felületi funkciós csoportok szerepe nitrogénnel adalékolt szenek $\mathrm{CO}_{2}$ redukciós aktivitásában}

\subsubsection{A katalizátorok előállítása és szerkezeti jellemzése}

A pórusméret hatásának vizsgálatát követően a katalizátorok felületi kémiai összetételének szerepét kívántuk tanulmányozni a $\mathrm{CO}_{2}$ redukcióban. Ennek érdekében különböző vezető polimer prekurzorokból állítottuk elő az N-C katalizátorokat azonos (27 nm) átlagos pórusmérettel. A szintézis az előző fejezetben ismertetett templát eljárással megegyező módon zajlott. Kiindulási anyagként tiszta PoPD, PANI és PPy polimereket (PoPD-C; PANI-C és PPy-C), valamint a PoPD és a PANI két különböző arányú keverékét alkalmaztuk. Utóbbi katalizátorokra a prekurzor polimerek arányának megfelelően a PANI(30)-PoPD(70)-C és PANI(70)-PoPD(30)-C neveken hivatkozom a továbbiakban. A PoPD-C minta esetén továbbá a pórusszerkezet szabályozása érdekében gyakran alkalmazott utólagos kémiai kezelések $\left(\mathrm{NH}_{3}\right.$ és $\mathrm{KOH}$ ) hatását is vizsgáltuk a $\mathrm{CO}_{2}$ redukcióban. Ezeket a kémiai aktiváló lépéseket elterjedten alkalmazzák szenekben mikropórusok kialakítása által a fajlagos felület növelésére. ${ }^{99,128,129} \mathrm{~N}$ adalékolt szén adszorbensek esetén megmutatták, hogy kis mikropórusok jelenléte jelentősen megnövelte a $\mathrm{CO}_{2}$ adszorpciós kapacitásukat, ${ }^{129}$ azonban ennek a $\mathrm{CO}_{2}$ redukcióra gyakorolt hatását korábban még nem vizsgálták. A KOH-os kezelés során a PoPD-C mintát tömény $\mathrm{KOH}$ oldatban (7 M) szuszpendáltuk, az oldószert vákuum alatt elpárologtattuk, majd a katalizátort $800{ }^{\circ} \mathrm{C}$-on $\mathrm{N}_{2}$ áramban hőkezeltük. A PoPD-C-KOH katalizátort ioncserélt vízzel való alapos mosást $(\mathrm{pH}<8)$ követően kaptuk. A PoPD-C-NH 3 katalizátort a PoPD-C ammónia áramban $900{ }^{\circ} \mathrm{C}$-on végzett hökezelésével állítottuk elő.

A TEM felvételeken (42. ábra) mind a tiszta, mind pedig a keverék polimer prekurzorokból előállított szenek esetén jól láthatók a templát részecskék által kialakított mezopórusok. Ezek átlagos pórusátmérője (PPy-C: $(26,2 \pm 2,9) \mathrm{nm}$; PANI-C: $(26,7 \pm 2,7) \mathrm{nm}$; PANI(30)-PoPD(70)-C: $(26,7 \pm 2,5) \mathrm{nm}$; PANI(70)-PoPD(30)-C: $(27,3 \pm 2,6)$ nm; PoPD-C: $(26,4$ $\pm 3,9)$ ) jól tükrözi a szilika nanorészecskék méretét. Az ammóniás kezelés megőrizte a PoPD-C mezopórusos jellegét, azonban az átlagos pórusméret kismértékben csökkent $((25,2 \pm 3,26) \mathrm{nm})$ a nem kezelt PoPD-C katalizátorhoz képest. Ezzel szemben a $\mathrm{KOH}-$ os kezelés drasztikus hatással volt a pórusszerkezetre. A PoPD-C-KOH TEM felvételén a mezopórusok már alig felfedezhetők, az aktiváló lépésben a szilika nanorészecskék által kialakított pórusok összeestek. 


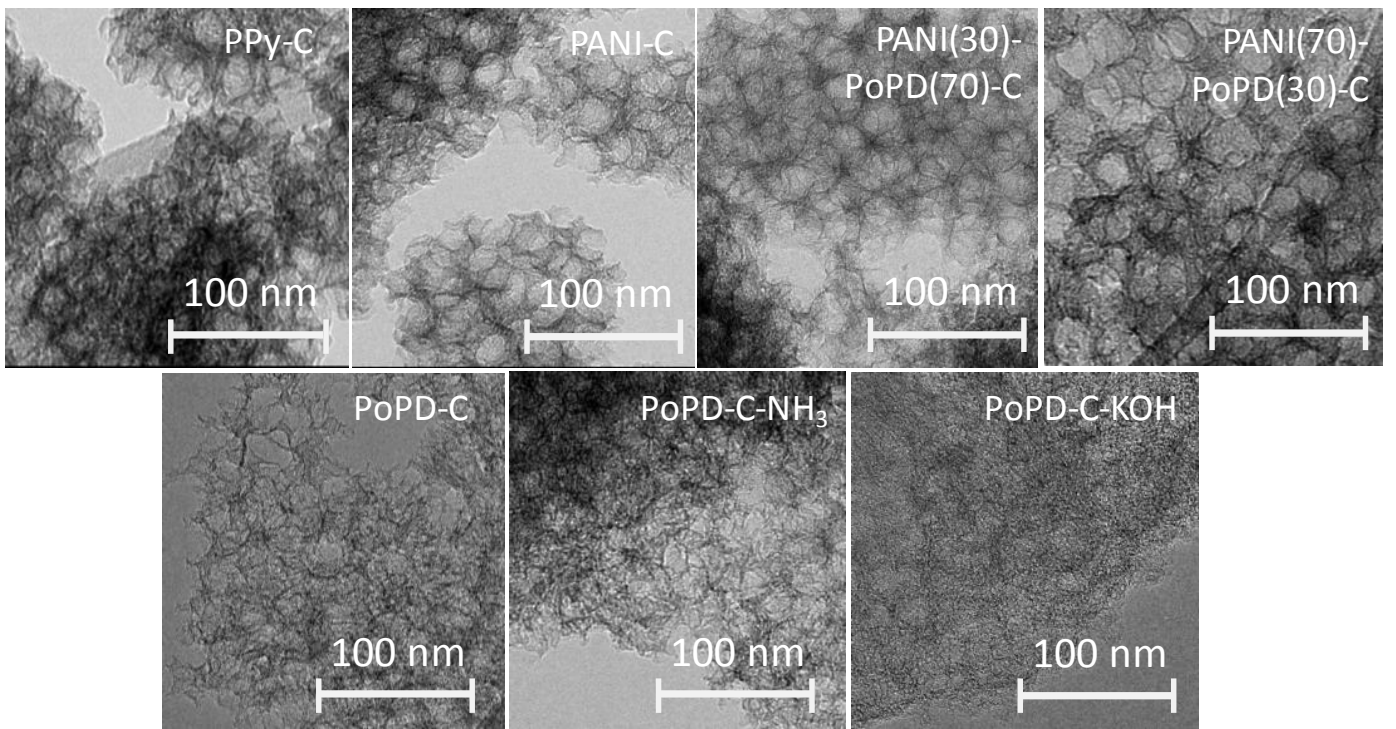

42. ábra: A különböző prekurzorokból előállított és az utólagos kémiai kezeléseknek alávetett N-C katalizátorok TEM felvételei.

A $\mathrm{N}_{2}$ adszorpciós / deszorpciós izotermákon (43. ábra) minden katalizátor esetén megfigyelhető a mezopórusos anyagokra jellemző hiszterézis hurok. Ez a PoPD-C-KOH minta esetén azt sugallja, hogy bár a $27 \mathrm{~nm}$ átméröjü pórusok mennyisége jelentősen lecsökkent a PoPD-C katalizátorhoz képest, a mezopórusos jelleg nem szünt meg teljesen. Ebben az esetben ráadásul a kis relatív nyomásokon jelentős adszorbeált térfogat mikropórusok jelenlétére utal. A BJH-módszerrel az izotermák adszorpciós ágából számított pórusméret eloszlás görbék a 44. ábrán láthatók a PoPD-C, PANI(30)-PoPD(70), a PANI-C-KOH és a PANI-C-NH 3 minták esetén. Mind a tiszta, mind pedig a keverék prekurzorok esetén kifejezett maximum látható 20 és $30 \mathrm{~nm}$ között, összhangban a TEM felvételekböl számított átlagos pórusméretekkel. A PoPDC-NH $\mathrm{N}_{3}$ mintánál ez a maximum azonban sokkal kevésbé kifejezett a PoPD-C-hez képest, míg a kis mezopórusok tartományában $(<5 \mathrm{~nm})$ megjelenő maximum dominánsabbá vált. A POPDC-KOH mintánál a mezopórusok tartományában gyakorlatilag nem látható maximum a pórusméret eloszlás görbén. Összességében tehát az ammóniás kezeléssel kisebb mezopórusok, míg a KOH-os kezeléssel mikropórusok alakultak ki a szénvázban. 


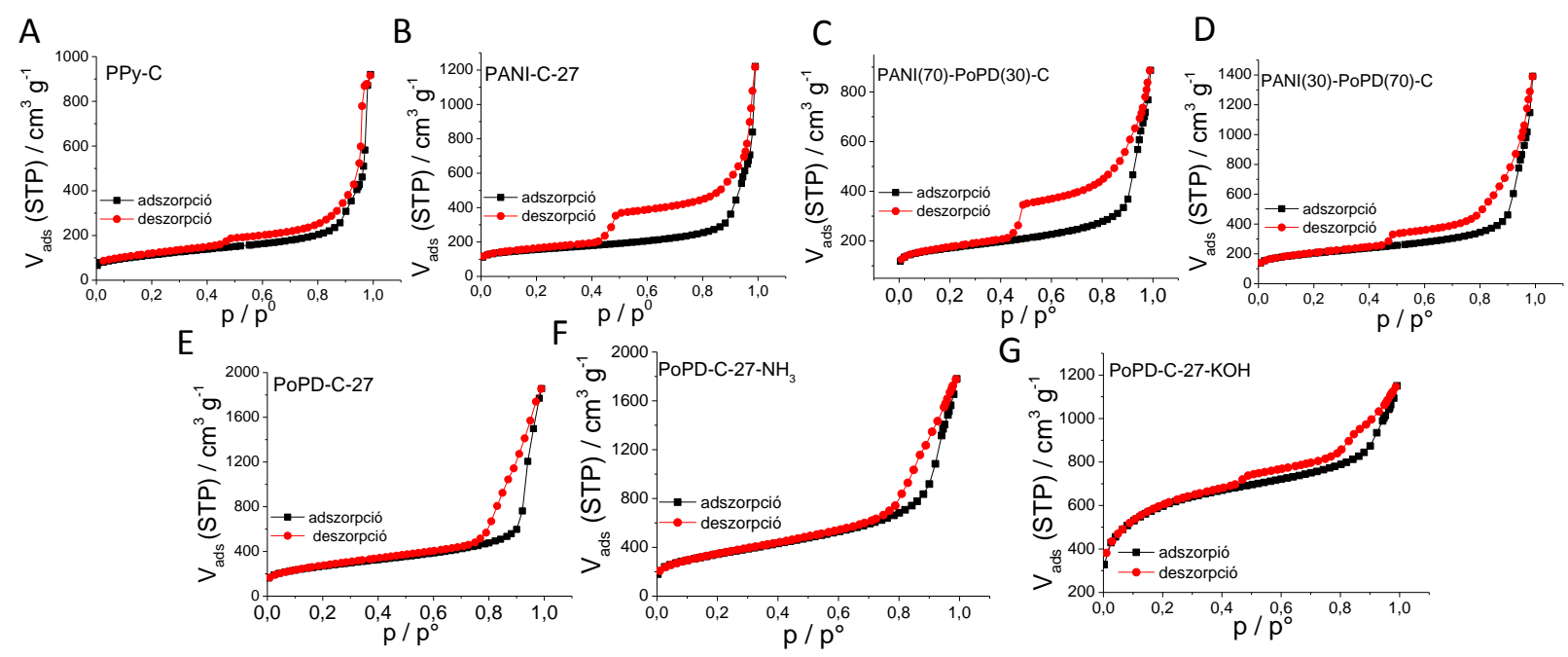

43. ábra: A vizsgált katalizátorok $\mathrm{N}_{2}$ adszorpciós / deszorpciós izotermái.

A

B
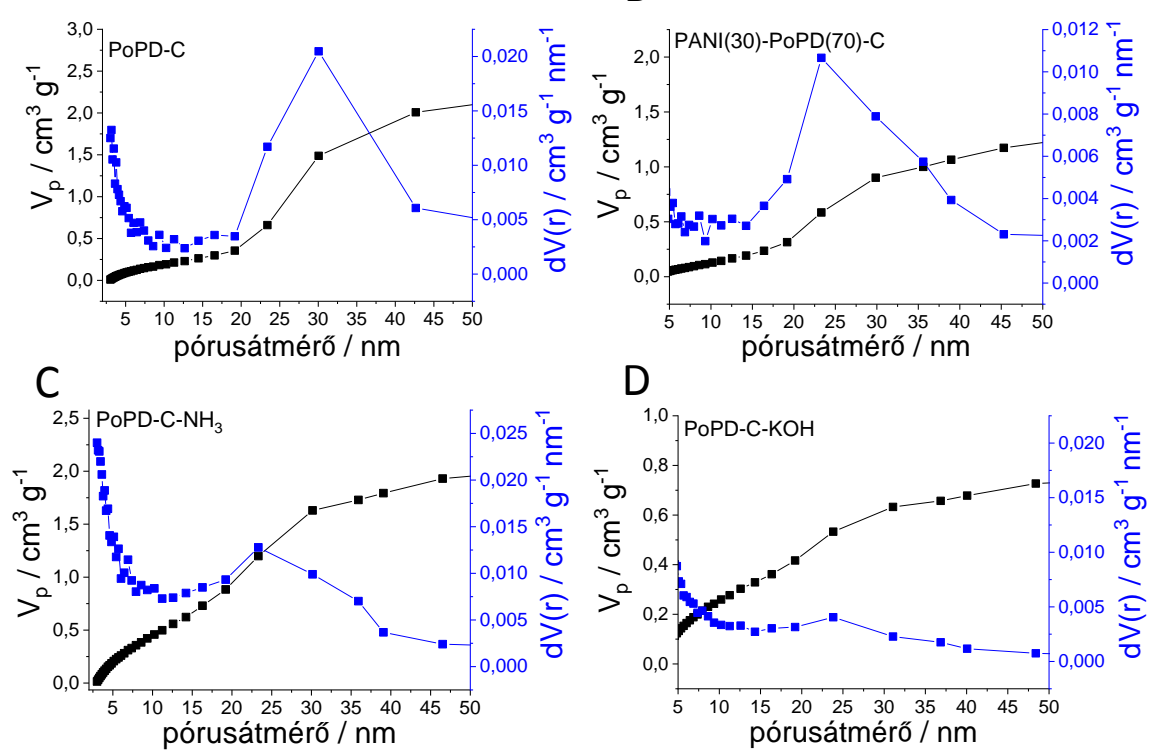

44. ábra: Az adszorpciós izotermákból a BJH módszerrel számított pórusméret eloszlás görbék a PoPD-C (A), PANI(30)-PoPD(70)-C, PoPD-C-NH3(C) és a PoPD-C-KOH (D) minták esetén.

Az izotermákból a BET módszerrel meghatároztuk a fajlagos felületeket, melyeket az 5. táblázatban foglaltam össze. A nem kezelt minták BET felületei $400-950 \mathrm{~m}^{2} \mathrm{~g}^{-1}$ között változtak. Bár a katalizátorok szintézise során a monomer / szilika arány azonos volt minden prekurzor esetén, az eltérő polimerizációs hatásfokok, illetve a polimerek karbonizációjának eltérő hozama okozhatta a fajlagos felületek különbségét. A keverék prekurzorokból előállított 
minták fajlagos felületei a PANI-C és PoPD-C minták felülete közé esett. Az ammóniás kezelés kismértékben, míg a $\mathrm{KOH}-o s$ aktiválás drasztikusan megnövelte a PoPD-C fajlagos felületét, összhangban a fentebb értelmezett pórusszerkezeti változásokkal.

5. táblázat: A katalizátorok $N_{2}$ adszorpciós izotermáiból meghatározott BET felületek, illetve az $1 \mathrm{mg}$ $\mathrm{cm}^{-2}$ borítottságú elektródok ciklikus voltammogramjaiból becsült relatív érdesség értékek.

\begin{tabular}{ccc}
\hline Katalizátor & BET felület $/ \mathbf{m}^{\mathbf{2}} \mathbf{g}^{-\mathbf{1}}$ & Relatív érdesség \\
\hline PoPD-C & 930 & 2293 \\
PPy-C & 403 & 1642 \\
\hline PANI-C & 563 & 1794 \\
\hline PANI(30)-PoPD(70)-C & 727 & 1825 \\
\hline PANI(70)-PoPD(30)-C & 621 & 1772 \\
\hline PoPD-C-27-NH & 1233 & 1982 \\
\hline PoPD-C-27-KOH & 2182 & 4060 \\
\hline
\end{tabular}

A

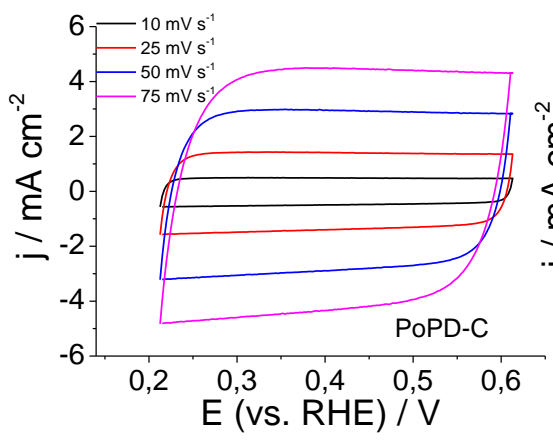

B

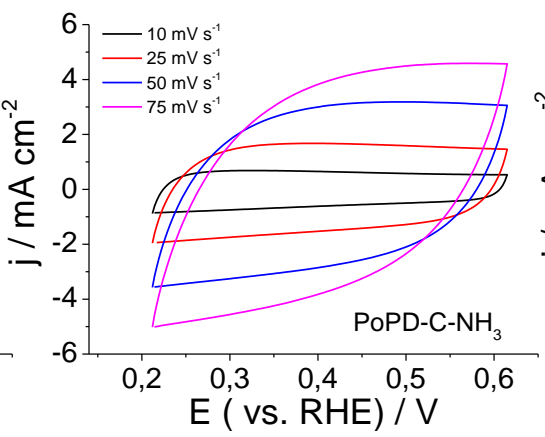

C

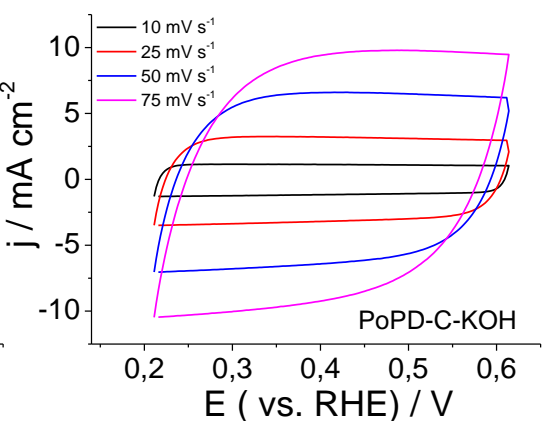

45. ábra: A PoPD-C (A); PoPD-C-NH3 (B) és a PoPD-C-KOH (C) katalizátorok ciklikus voltammogramjai Ar-nal buborékoltatott $1 \mathrm{M} \mathrm{Na}_{2} \mathrm{SO}_{4}$ oldatban különbözö pásztázási sebességekkel.

$\mathrm{Az}$ üvegszén elektródokra felvitt $1 \mathrm{mg} \mathrm{cm}^{-2}$ borítottságú katalizátor rétegek elektrokémiailag aktív felületét (relatív érdességét) a ciklikus voltammogramokból (45. ábra) meghatározott töltéskapacitás értékekből becsültük. A relatív érdesség értékek és a BETfelületek között lineáris összefüggés állt fent, melytől egyedül a PoPD-C-NH 3 minta tért el (46. A ábra). Ennek oka a PoPD-C-NH 3 többi mintához képesti kisebb elektromos vezetése, melyet a ciklikus voltammogramok ideális téglalap alakhoz képesti jelentősebb torzulása (45. B ábra), és elektrokémiai impedancia spektroszkópiás mérések (46. B ábra) is igazoltak. A PoPD-C$\mathrm{NH}_{3}$ töltésátviteli ellenállása a PoPD-C mintához képest mintegy egy nagyságrenddel 
növekedett. Nagy valószínűséggel az ammóniás kezelés hatására egy hibahelyekben gazdagabb szén struktúra alakult ki.
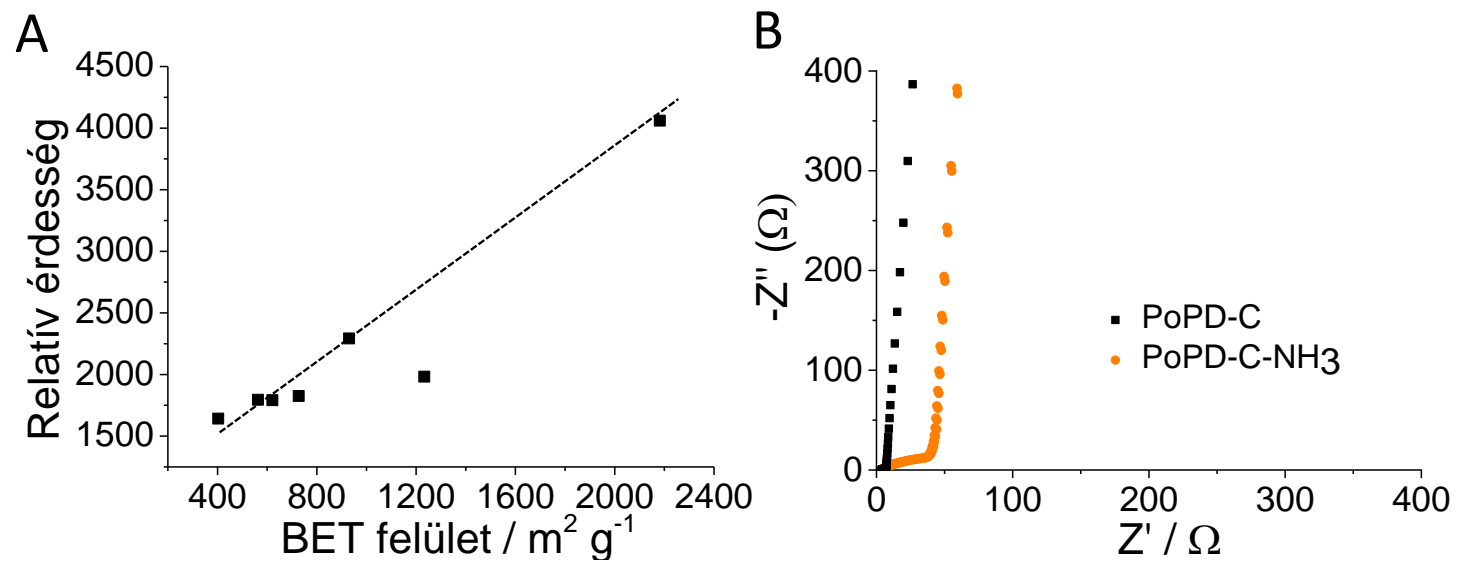

46. ábra: (A) Összefüggés az elektródok relatív érdessége és BET felületük között. (B): A PoPD-C és a PoPD-C- $\mathrm{NH}_{3}$ elektródok elektrokémiai impedancia spektrumai Ar gázzal buborékoltatott $1 \mathrm{M} \mathrm{Na}_{2} \mathrm{SO}_{4}$ oldatban.

A katalizátorok felületi kémiai összetételét XPS módszerrel tanulmányoztuk. A vizsgált minták nitrogént, oxigént, szenet, valamint nyomnyi mennyiségű kenet tartalmaztak (6. táblázat). A kezeletlen $\mathrm{N}-\mathrm{C}$ katalizátorok relatív nitrogéntartalma jó egyezést mutatott a kiindulási monomerek N-tartalmával (PoPD-C közel kétszeres nitrogéntartalma a PPy-C és PANI-C mintákhoz képest). Az ammóniás kezelés során mintegy 30\%-kal csökkent a Ntartalom a nem kezelt PoPD-C mintához képest, míg a KOH-os kezelés esetén ez a csökkenés több, mint $80 \%$-os volt.

6. táblázat: A különböző prekurzorokból előállított és utólagos kémiai kezelésnek alávetett N-C katalizátorok felületének elemi összetétele.

\begin{tabular}{cccc}
\hline Katalizátor & C / rel. \% & N / rel. \% & O / rel. \% \\
\hline PoPD-C & 82,86 & 9,57 & 6,46 \\
PPy-C & 80,24 & 5,75 & 13,52 \\
PANI-C & 83,90 & 6,65 & 8,98 \\
PANI(30)-PoPD(70)-C & 87,13 & 8,46 & 4,41 \\
PANI(70)-PoPD(30)-C & 84,25 & 8,36 & 7,39 \\
PoPD-C-NH3 & 89,13 & 6,45 & 4,42 \\
PoPD-C-KOH & 91,70 & 1,53 & 6,78 \\
\hline
\end{tabular}


A prekurzorok anyagi minőségével nemcsak a katalizátorok elemi összetétele, hanem a különböző típusú N-atomok aránya is változott (47. ábra). A tiszta prekurzorokból előállított katalizátorok közül a PPy-C tartalmazott legnagyobb arányban piridines N-t, míg a PoPD-C mintának volt a legnagyobb relatív grafitos $\mathrm{N}$-tartalma. Az ammóniás kezelés hatására az oxidált $\mathrm{N}$-atomok, míg a KOH-os kezelés következtében az amin N-atomok aránya növekedett a PoPDC katalizátorhoz képest.

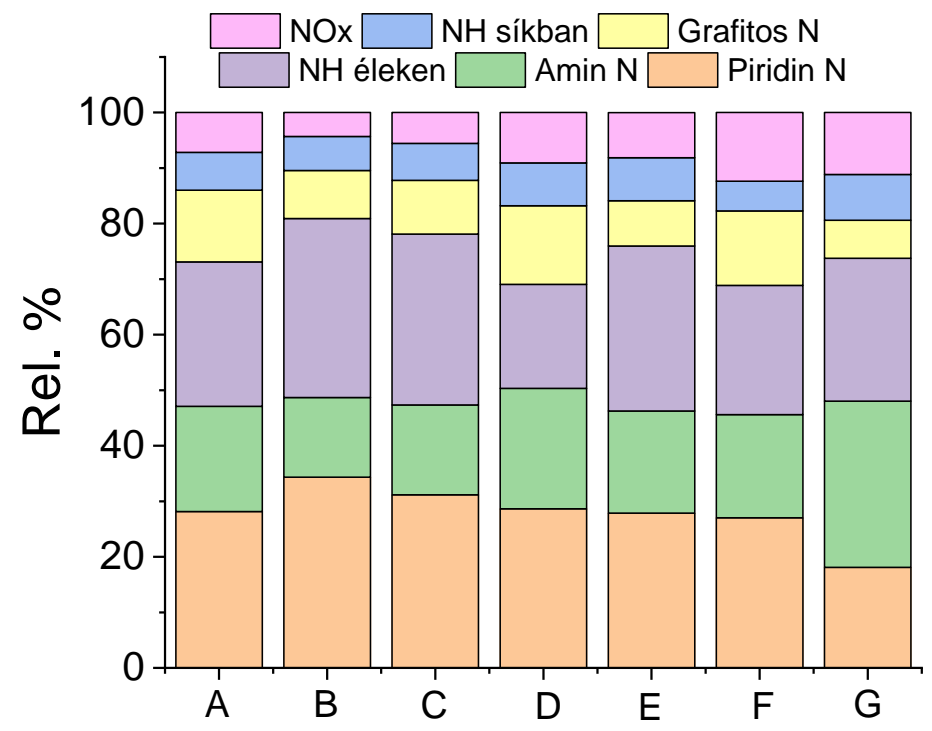

47. ábra: A vizsgált N-C katalizátorok különböző kémiai környezetü N-atomjainak az aránya. (A: PoPDC, B: PPy-C, C: PANI-C, D: PANI(70)-PoPD(30)-C, E: PANI(30)-PoPD(70)-C, F: PoPD-C-NH3, G: PoPDC-KOH).

\subsection{2. $\mathrm{CO}_{2}$ redukciós aktivitás}

Az $\mathrm{N}-\mathrm{C}$ elektródok $\mathrm{CO}_{2}$ redukciós aktivitásának felderítése érdekében a $-0,5$ és $-0,9$ V (vs. RHE) közötti tartományon potenciosztatikus elektrolízis kísérleteket végeztünk a képződő termékek analízisével együtt. Fő $\mathrm{CO}_{2}$ redukciós termékként ebben az esetben is $\mathrm{CO}$ keletkezett, kis mennyiségủ metán képződése mellett. A 48. ábrán a teljes redukciós áramok és a képződő $\mathrm{CO}$ és $\mathrm{H}_{2}$ mólarányai láthatók az elektrolízisek 40. percében, mind a különböző prekurzorokból elöállított, mind pedig az utólagos kémiai kezeléseknek alávetett katalizátorok esetén. A különböző prekurzorok hatását tekintve a PoPD-C mutatta a legnagyobb teljes áramsürüséget, melytől csupán kis mértékben maradt el a PANI(30)-PoPD(70)-C minta. A CO / $\mathrm{H}_{2}$ arány azonban ez utóbbi minta esetén volt a nagyobb, mely szelektivitásnövekedés a kisebb túlfeszültségeken volt kifejezettebb (-0,6 V-on közel másfélszeres növekedés). A polipirrolból 
és a tisztán polianilinből készült minták közel azonos aktivitással és CO szelektivitással bírtak, jelentősen elmaradva a többségében PoPD prekurzorból előállított katalizátorok teljesítményétől. A keverék prekurzorokból előállított katalizátorok aktivitása és szelektivitása is a tiszta prekurzorokból előállított mintáknál tapasztaltak közé esett, a polimerek arányának megfelelően. A PoPD jelenléte a prekurzorban tehát növelte a teljes redukciós aktivitást és a CO szelektivitást, nagy valószínüséggel a nagyobb N-tartalom miatt.
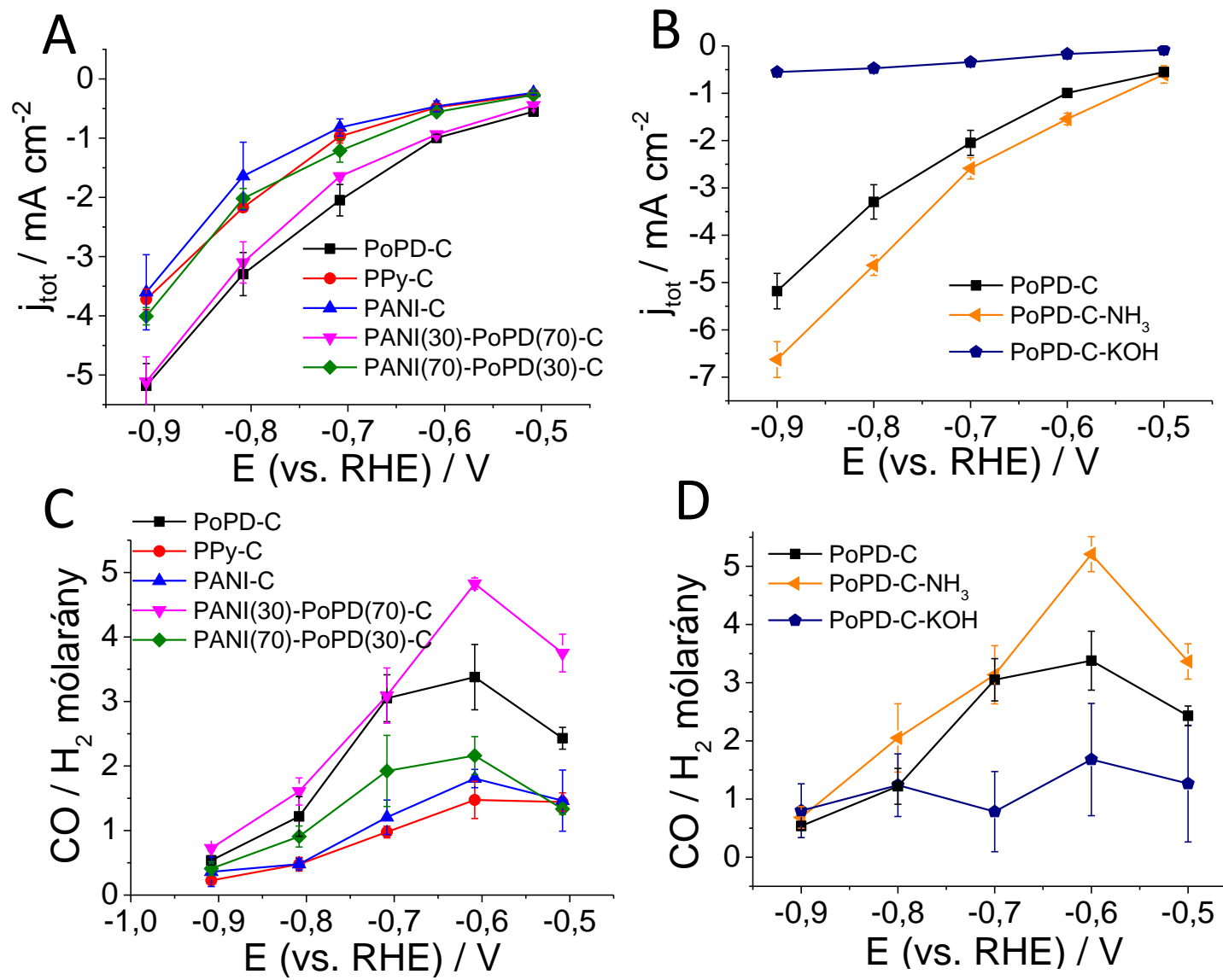

48. ábra: A potenciosztatikus elektrolízisek során mért teljes áramsürüségek $(A, B)$, valamint a képződő CO és $\mathrm{H}_{2}$ mólaránya $(C, D)$ a különböző prekurzorokból előállított $(A, C)$ és utólagos kémiai kezeléseknek alávetett minták esetén (B,D).

Az ammóniás kezelés kb. másfélszeres növekedést eredményezett a teljes redukciós áramban és a CO szelektivitásban $(-0,6 \mathrm{~V})$ is a nem kezelt PoPD-C mintához képest. Ez a katalizátor tehát még a nagyobb töltésátviteli ellenállás és a kisebb $\mathrm{N}$-tartalom ellenére is kedvezőbb $\mathrm{CO}_{2}$ redukciós tulajdonságokkal rendelkezett. Ezen megfigyelés pontos hátterét még nem ismerjük, ugyanakkor azt mindenképpen jelzi, hogy a funkciós csoport jellegén és mennyiségén, valamint az elektromos tulajdonságokon túl más paraméter is hatással kell, hogy 
bírjon az elektrokatalitikus aktivitásra. ${ }^{55}$ Ezzel szemben a KOH-os kezelés hatására drasztikusan lecsökkent a teljes redukciós áram (öt-tízszeres aktivitáscsökkenés) és a CO szelektivitás is (kétháromszoros csökkenés kisebb túlfeszültségeken), aminek a jelentősen kisebb N-tartalom a valószínüsíthető oka.

Az N-C elektródok relatív érdesség értékekkel normált parciális CO áramsürüségei a 49. ábrán láthatók. Ebben az esetben a különböző prekurzorokból előállított katalizátorok között a PANI(30)-PoPD(70)-C minta mutatta a legnagyobb CO parciális áramsürüséget. A többi minta sorrendje egyezett a geometriai felülettel való normálás esetén tapasztalt trenddel, éppúgy, mint az utólagos kémiai kezeléseknek alávetett minták esetén. Összességében a $\mathrm{CO}_{2}$ redukciós aktivitás (CO parciális áramsürüsége) a katalizátorok teljes nitogéntartalmával növekedett. Ez alól csupán a PoPD-C-NH 3 minta volt kivétel, mely pontos okának felderítése további vizsgálatokat igényel.
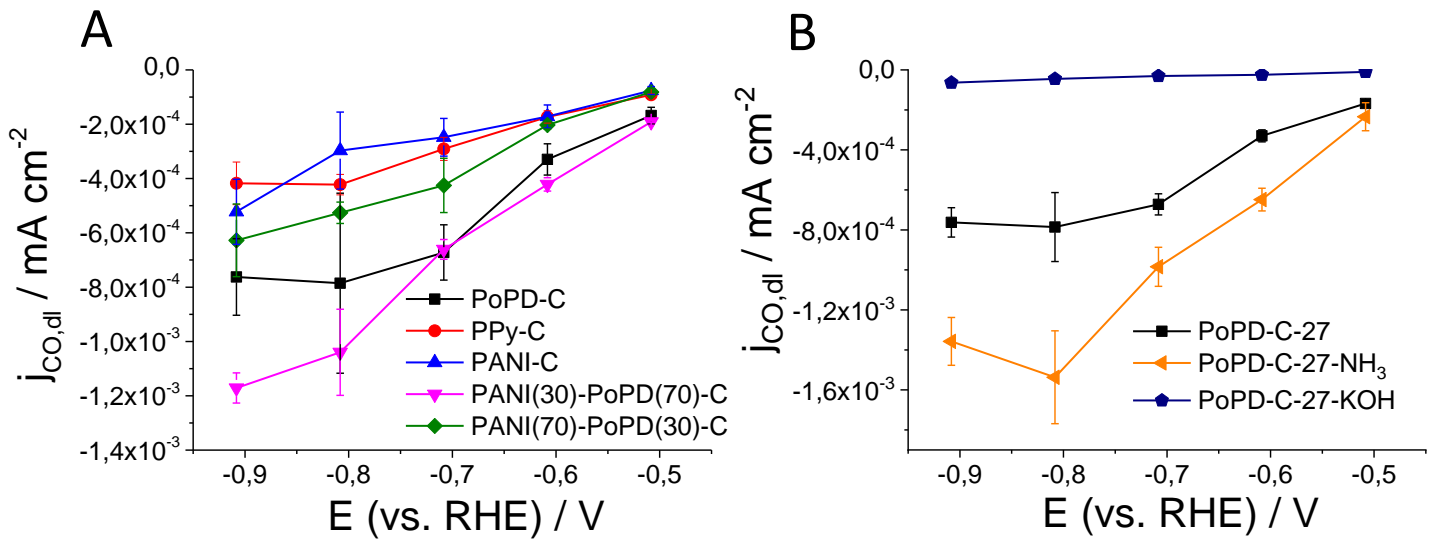

49. ábra: A relatív érdesség értékekkel normált CO-fejlődésre vonatkozó parciális áramsűrüségek az elektrolízis kísérletek 40. percében a különböző prekurzorokból előállított N-C katalizátorok (A), valamint az utólagos kémiai kezeléseknek alávetett PoPD-C minták esetén (B). Az elektródok borítottsága $1 \mathrm{mg} \mathrm{cm}^{-2}$ volt, a méréseket $\mathrm{CO}_{2}$-dal telített $0,1 \mathrm{M} \mathrm{KHCO} 3$ oldatban végeztük.

A vizsgált $\mathrm{N}-\mathrm{C}$ katalizátorokon nagyon kis mennyiségben metán is keletkezett (50. ábra). A kis Faraday-hatásfokok ellenére $(<1 \%)$ mégis érdemes említést tenni erről, hiszen szénhidrogének képződését néhány kivételtől eltekintve, ${ }^{29,54,79}$ szinte kizárólag csak réz ${ }^{130-132}$ és molekuláris katalizátorok ${ }^{133}$ esetén tapasztalták. Emiatt igen érdekes lenne fényt deríteni arra, hogy mi a mechanizmusa, illetve milyen tényezők játszanak szerepet a metán képződésében fémmentes $\mathrm{N}-\mathrm{C}$ katalizátorokon. Érdekes módon a legnagyobb CO Faraday-hatásfokot a 
legkisebb teljes aktivitással és CO-szelektivitással bíró PoPD-C-KOH minta mutatta. $\mathrm{A} \mathrm{CH}_{4}$ / CO arány szintén ebben az esetben és a PANI-C mintánál volt a legnagyobb.
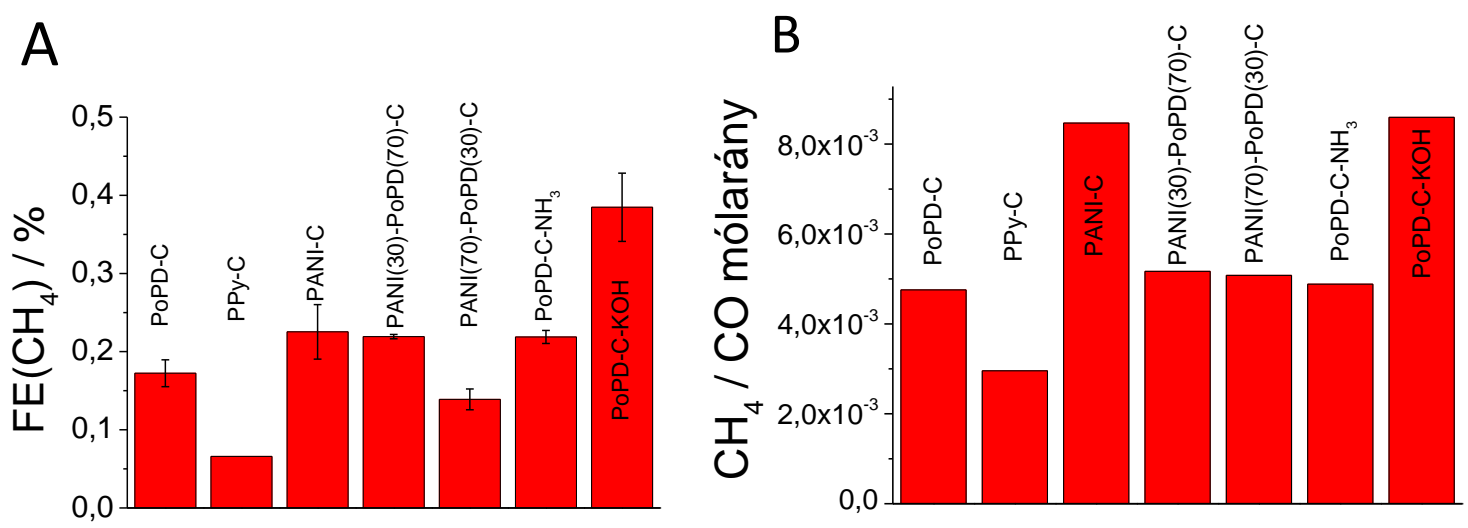

50. ábra: A képződő metán Faraday-hatásfoka a különböző katalizátorokon -0,9 V-on, az elektrolízisek 75. percében. (B): A képződő $\mathrm{CH}_{4}$ és CO mólaránya.

\subsubsection{A katalizátorok aktivitása $\mathrm{CO}_{2}$ termikus hidrogénezésében}

Az elektrokémiai $\mathrm{CO}_{2}$ redukció heterogén katalitikus megfelelöje a $\mathrm{CO}_{2}$ termikus hidrogénezése. ${ }^{134,135}$ Ebben az esetben a folyamat energiaigényét elektromos energia helyett termikus energia biztosítja. Azt kívántuk vizsgálni, hogy azonos katalizátorok alkalmazása során a folyamat szelektivitását befolyásolja-e, illetve miként befolyásolja az, hogy a szükséges energia milyen forrásból származik. Ennek érdekében egy állóágyas reaktorban $300{ }^{\circ} \mathrm{C}$ és 700 ${ }^{\circ} \mathrm{C}$ között vizsgáltuk a különböző prekurzorokból elóállított katalizátoroknak a $\mathrm{CO}_{2}$ termikus hidrogénezési reakciójában mutatott aktivitását.

A termikus hidrogénezési reakcióban $\mathrm{CO}$ és $\mathrm{CH}_{4}$ képződött termékként (51. ábra), hasonlóan az elektrokémiai redukcióhoz. A CO képződése $825 \mathrm{~K}$-en indult mindegyik minta esetén. A $\mathrm{CH}_{4}$ képződése a PANI(70)-PoPD(30)-C minta esetén $825 \mathrm{~K}$-en, míg a többi katalizátoron $875 \mathrm{~K}$-en kezdődött. A CO képződési sebessége a PPy-C < PANI(70)-PoPD(30)$\mathrm{C}<\mathrm{PoPD}-\mathrm{C} \cong \mathrm{PANI}-\mathrm{C}<\mathrm{PANI}(30)-\mathrm{PoPD}(70)-\mathrm{C}$ sorrendben növekedett. Ez a sorrend a PANIC minta kivételével összhangban volt az elektrokémiai redukció során a CO parciális áramok sorrendjével, ami azt jelzi, hogy a két folyamatban az aktív centrumok anyagi minősége azonos. A termikus hidrogénezés során a képződő $\mathrm{CH}_{4}$ és $\mathrm{CO}$ aránya kb. egy nagyságrenddel nagyobb volt az elektrokémiai redukcióban tapasztalthoz képest. Ennek valószínű oka, hogy az elektrokémiai redukció során a $\mathrm{H}_{2}$-fejlődés visszaszorította a $\mathrm{CH}_{4}$ képződését. 
A

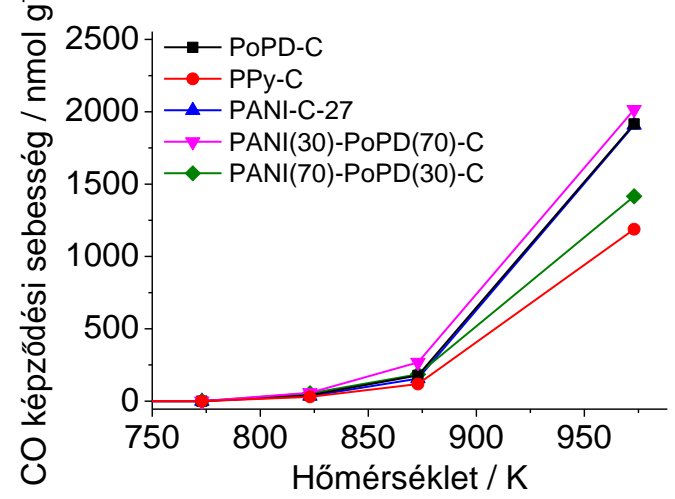

$\mathrm{B}$ in

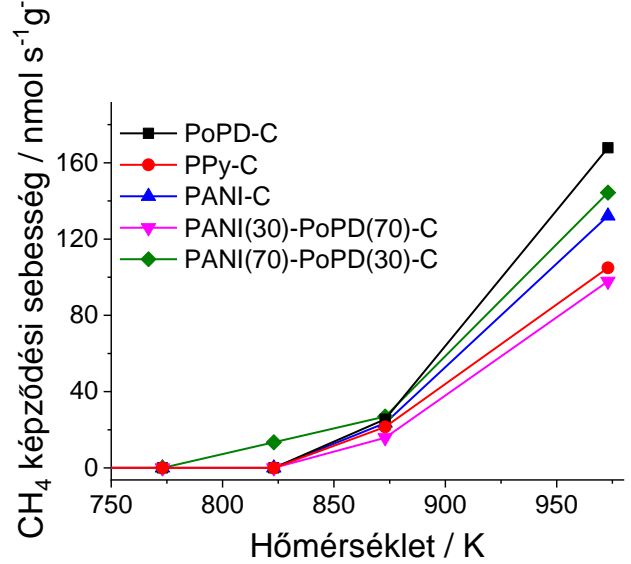

51. ábra: A CO és a $\mathrm{CH}_{4}$ képződési sebessége a $\mathrm{CO}_{2}$ termikus hidrogénezési reakciójában a különbözö prekurzorból előállított N-C katalizátorok esetén. 


\subsection{Fémmel és nitrogénnel adalékolt szén katalizátorok vizsgálata $\mathrm{CO}_{2}$ redukcióban és $\mathrm{H}_{2}$ fejlesztésben}

\subsubsection{A katalizátorok előállítása}

Négy különböző fémtartalmú $\mathrm{M}-\mathrm{N}-\mathrm{C}$ és egy fémmentes $\mathrm{N}-\mathrm{C}$ katalizátort állítottunk elő hard templát módszerrel. Nitrogén és szén prekurzorként 4-aminoantipirint (AAPyr), fém prekurzorokként réz-nitrátot, prazeodímium-nitrátot, cérium-nitrátot és ammóniumheptamolibdátot használtunk. Első lépésként szuszpenziót készítettünk az aminoantipirinből, az adott fém sójából és a szilika templát részecskékből (50-70 nm átmérö). A szuszpenziót bepároltuk, majd a kapott porkeveréket $\mathrm{N}_{2}$ áramban karbonizáltuk. A hökezelés során visszamaradt szénből a szilika templát részecskéket hidrogén-fluorid oldattal oldottuk ki, majd közel semleges $\mathrm{pH}$ eléréséig ioncserélt vízzel alaposan mostuk a mintákat. $\mathrm{Az} \mathrm{M}-\mathrm{N}-\mathrm{C}$ katalizátorokat levegőn történő szárítást és egy 10\% ammóniát tartalmazó nitrogénáramban történő második hőkezelést $\left(945^{\circ} \mathrm{C}\right)$ követően kaptuk. A fémmentes $\mathrm{N}-\mathrm{C}$ katalizátort fém prekurzor alkalmazása nélkül, de azonos módon állítottuk elö.

\subsubsection{A katalizátorok szerkezeti jellemzése}

Az M-N-C katalizátorokban a kristályos fázisok jelenlétét XRD mérésekkel vizsgáltuk (52. ábra). $\mathrm{A} \operatorname{Pr}-\mathrm{N}-\mathrm{C}$ és a $\mathrm{Cr}-\mathrm{N}-\mathrm{C}$ esetén megjelenő éles reflexiók kizárólag a megfelelő fluoridok $\left(\mathrm{PrF}_{3}\right.$ és $\left.\mathrm{CrF}_{3}\right)$ jelenlétéhez voltak köthetők, míg a $\mathrm{Cu}-\mathrm{N}-\mathrm{C}$ katalizátorban a domináns $\mathrm{Cu}_{7}(\mathrm{OH})_{10} \mathrm{~F}_{4}$ fázis mellett kisebb arányban $\mathrm{CuO}, \mathrm{Cu}_{2} \mathrm{O}$ és $\mathrm{Cu}$ is azonosítható volt. ${ }^{136} \mathrm{Az}$ Mo-N-C mintában ezzel szemben az XRD vizsgálat kristályos fázisokat nem mutatott. A hidrogén-fluoridos kioldás során ezeket valószínüleg eltávolítottuk, hiszen a molibdénfluoridok és oxi-fluoridok vízoldható vegyületek. Fontos továbbá, hogy az alkalmazott szintézis módszer a kristályos fémfázisokon túl rendszerint atomosan eloszlatott fémcentrumok kialakulásához is vezet, melyek bizonyítottan aktív centrumok lehetnek elektrokatalitikus folyamatokban. ${ }^{38}$ 


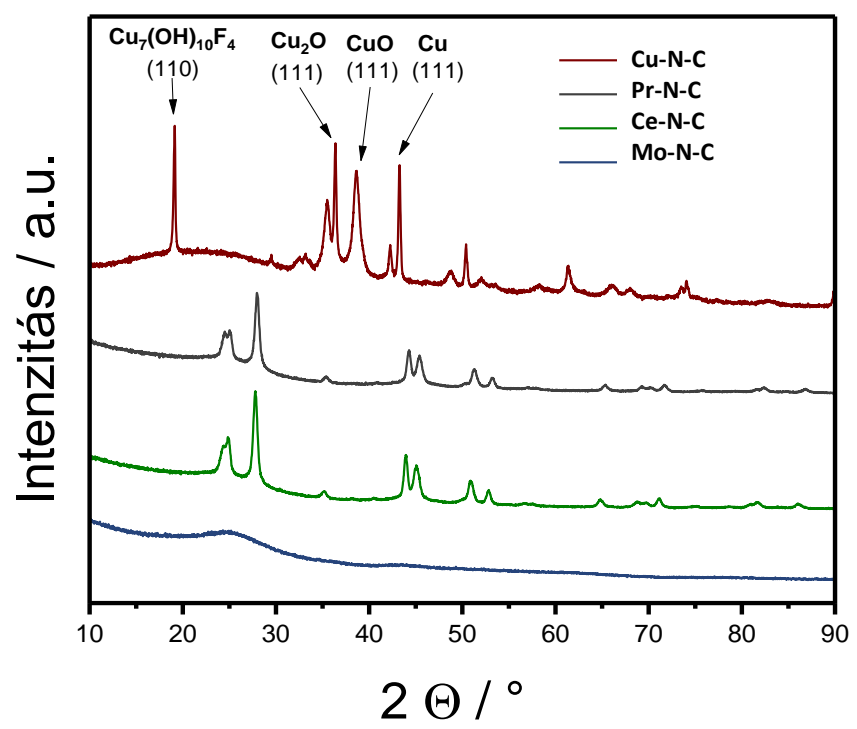

52. ábra: A vizsgált $\mathrm{M}-\mathrm{N}-\mathrm{C}$ katalizátorok röntgendiffraktogramjai.

A katalizátorok morfológiáját és a fém részecskék eloszlását a szénvázban transzmissziós- és pásztázó elektronmikroszkópiával vizsgáltuk. A SEM képen (53. ábra) megfigyelhető, hogy az M-N-C katalizátorok pórusos szerkezetüek, ami az elősegíti az aktív centrumok elérhetőségét. A pórusok kialakulása egyrészt a szintézis során a szilika templát részecskék jelenlétének (majd eltávolításának), másrészt a szerves prekurzor hőbomlásának volt a következménye. A $\mathrm{Ce}-\mathrm{N}-\mathrm{C}, \mathrm{Cu}-\mathrm{N}-\mathrm{C}$ és $\mathrm{Pr}-\mathrm{N}-\mathrm{C}$ minták TEM felvételén (54. ábra) jól láthatók a 20-50 nm átmérőjü nanorészecskék, összhangban az XRD eredményekkel. Ezek mellett néhány nanométeres részecskék is megfigyelhetők voltak a nagyfelbontású felvételeken (ezek nem szerepelnek a disszertációban). Az Mo-N-C mintában ezzel szemben csak kis nanorészecskék (néhány $\mathrm{nm}$ ) voltak láthatók, melyek kis méretük miatt nem adtak XRD jelet. A néhány nm átmérőjű részecskék legnagyobb mennyiségben a $\mathrm{Cu}-\mathrm{N}-\mathrm{C}$ és a $\mathrm{Mo}-\mathrm{N}-\mathrm{C}$ mintákban voltak jelen.

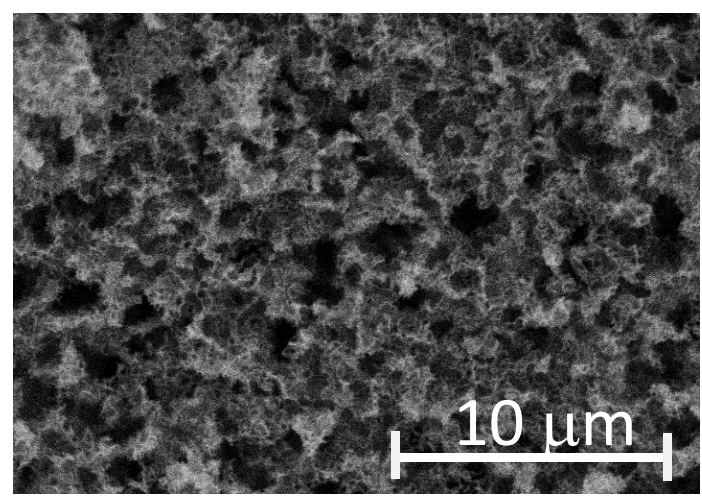

53. ábra: A Cu-N-C katalizátor SEM felvétele. 


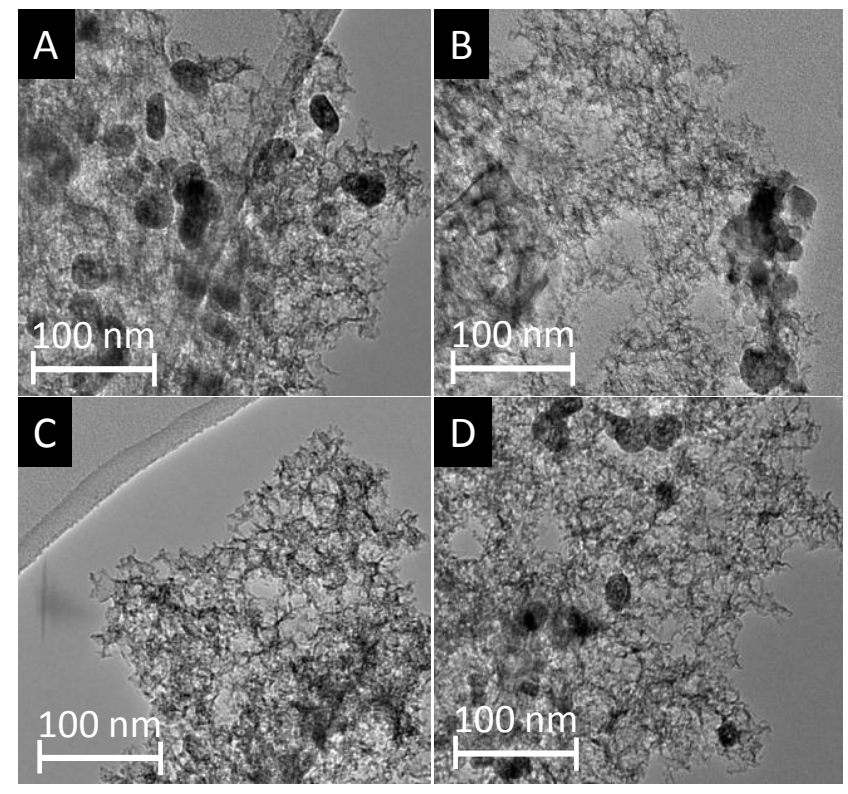

54. ábra: Az M-N-C katalizátorok TEM-felvételei. (A): Ce-N-C, (B): Cu-N-C, (C): Mo-N-C, (D): Pr-N-C.

A katalizátorok felületének kémiai összetételét XPS mérésekkel vizsgáltuk (7-8. táblázat és 55. ábra). Az egyes minták elemi összetételét és a különbözö típusú $\mathrm{N}$-atomok relatív arányát a 7. és 8. táblázatok foglalják össze. A katalizátorok $\mathrm{N}$-tartalma 3 és 6 atom\% között változott, a fémmentes $\mathrm{N}-\mathrm{C}$ tartalmazta a legkevesebb nitrogént. Ez azt sugallja, hogy a fém prekurzorok jelenléte a pirolízis körülményeit is befolyásolta. A különböző fém prekurzorok az elemi összetétel mellett a különböző kémiai környezetű N-atomok eloszlására is hatással voltak (55. B ábra). Utóbbiak közül a piridines- és a hidrogénezett nitrogénnek volt a legnagyobb a hozzájárulása, kivéve a $\mathrm{Ce}-\mathrm{N}-\mathrm{C}$ esetén. A fémmentes katalizátorban volt legnagyobb mennyiségben jelen hidrogénezett $\mathrm{N}$, míg az Mo-N-C és a $\mathrm{Cu}-\mathrm{N}-\mathrm{C}$ katalizátorokban volt a legtöbb piridines $\mathrm{N}$. A Pr-N-C mintának, amellett, hogy a legkisebb volt a $\mathrm{N}$ - és a fémtartalma, a legnagyobb mennyiségben tartalmazott hidrogénezett nitrogént. Végül a $\mathrm{Ce}-\mathrm{N}-\mathrm{C}$ mintában volt a legkevesebb piridines $\mathrm{N}$, azonban a legnagyobb mennyiségben tartalmazott oxidált és protonált $\mathrm{N}-\mathrm{t}$ a vizsgált $\mathrm{M}-\mathrm{N}-\mathrm{C}$ katalizátorok közül. 
7. táblázat: A vizsgált katalizátorok elemi összetétele relatív atomszázalékban.

\begin{tabular}{ccccc}
\hline & C / \% & O / \% & N / \% & M / \% \\
\hline Mo-N-C & 84,2 & 7,7 & 4,9 & 3,2 \\
\hline Ce- N -C & 83,2 & 10,4 & 5,4 & 1,0 \\
Pr- N -C & 85,5 & 10,9 & 3,4 & 0,2 \\
Cu- N -C & 77,3 & 14,0 & 5,8 & 3,0 \\
N-C & 93,9 & 3,6 & 2,6 & 0,0 \\
\hline
\end{tabular}

8. táblázat: A különböző kémiai környezetü $\mathrm{N}$-atomok eloszlása a vizsgált katalizátorokban relatív atomszázalékban kifejezve.

\begin{tabular}{cccccc}
\hline & $\begin{array}{c}\text { Piridines N / } \\
\text { \% }\end{array}$ & $\begin{array}{c}\mathbf{N}_{\mathbf{x}}-\mathbf{M} / \mathbf{a m i n} \mathbf{N} / \\
\boldsymbol{\%}\end{array}$ & $\mathbf{N}-\mathbf{H} / \boldsymbol{\%}$ & $\mathbf{N}_{\mathbf{g r}}+\mathbf{N}^{+} / \boldsymbol{\%}$ & $\mathbf{N}^{+} / \mathbf{N O} / \boldsymbol{\%}$ \\
\hline Mo-N-C & 42 & 9 & 27 & 17 & 5 \\
\hline Ce- N -C & 15 & 16 & 24 & 12 & 33 \\
\hline Pr- N -C & 27 & 16 & 33 & 9 & 15 \\
\hline Cu- N -C & 31 & 19 & 26 & 10 & 14 \\
\hline N-C & 15 & 11 & 30 & 21 & 23 \\
\hline
\end{tabular}

Míg a $\mathrm{Cu}-\mathrm{N}-\mathrm{C}$ és $\mathrm{Mn}-\mathrm{N}-\mathrm{C}$ minták viszonylag nagy fémtartalommal rendelkeztek ( $\mathrm{kb}$. 3\%), a Pr-N-C csupán nyomnyi prazeodímiumot tartalmazott. Azonban nemcsak a szénvázban lévő fém mennyisége, hanem annak minősége is kiemelkedően fontos az elektrokatalitikus aktivitás meghatározásában (55. A és C ábra). Az XPS spektrumok alapján a Ce-tartalmú mintában fémes Ce és fém-oxidok voltak jelen, míg a $\mathrm{Pr}-\mathrm{N}-\mathrm{C}$ katalizátorban leginkább Pr-oxid. $\mathrm{A} \mathrm{Cu}-\mathrm{N}-\mathrm{C}$ esetén a jelentős mennyiségü fém réz mellett réz-oxidok és $\mathrm{Cu}-\mathrm{N}$ kötések jelenlétét is felfedte az XPS analízis, a Mo-N-C mintában pedig fém-oxidok és N-hez koordinálódott Mo volt található. 

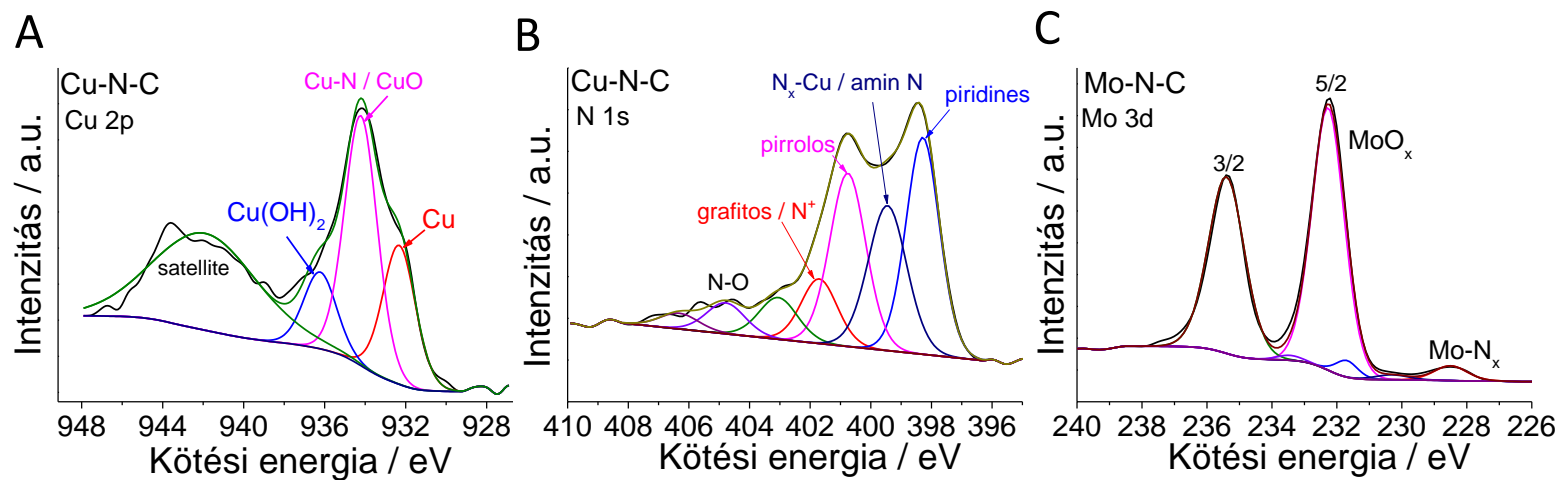

55. ábra: Az M-N-C katalizátorok nagyfelbontású XPS spektrumai. (A): A Cu-N-C Cu 2p spektruma. (B): A $\mathrm{Cu}-\mathrm{N}-\mathrm{C} \mathrm{N}$ 1s spektruma. (C): A Mo-N-C Mo 3d spektruma.

\subsubsection{Elektrokémiai tulajdonságok}

Az elektrokatalitikus aktivitás vizsgálatát megelőzően ciklikus és lineáris voltammetriás méréseket végeztünk a katalizátor rétegvastagságának optimalizálása és az elektrokémiailag aktív felületek meghatározása érdekében. A $\mathrm{Cu}-\mathrm{N}-\mathrm{C}$ minta esetén három különböző borítottságú $\left(0,6 \mathrm{mg} \mathrm{cm}^{-2} ; 1,4 \mathrm{mg} \mathrm{cm}^{-2}\right.$ és $\left.1,9 \mathrm{mg} \mathrm{cm}^{-2}\right)$ elektródot készítettünk és felvettük az elektródok ciklikus voltammogramjait egy olyan potenciáltartományon, ahol Faraday-folyamat nem történik (56. A ábra). A ciklikus voltammogramok alakja csak kismértékủ eltérést mutatott az ideális négyzetes alaktól és a kapacitív áramsürüségek lineárisan növekedtek a felvitt katalizátor tömegével. Ez a vizsgált minták jó elektromos vezetésére utal. $\mathrm{A} \mathrm{CO}_{2}$ jelenlétében felvett lineáris voltammogramokon (56. B ábra) a Faraday-áram (E < -0,4 V) az $1,4 \mathrm{mg} \mathrm{cm}^{-2}$ borítottságú $\mathrm{Cu}-\mathrm{N}-\mathrm{C}$ elektród esetén volt a legnagyobb. Ennél nagyobb rétegvastagságnál nem volt további áramnövekmény, ezért a további vizsgálatok során ezt a rétegvastagságot alkalmaztuk. 

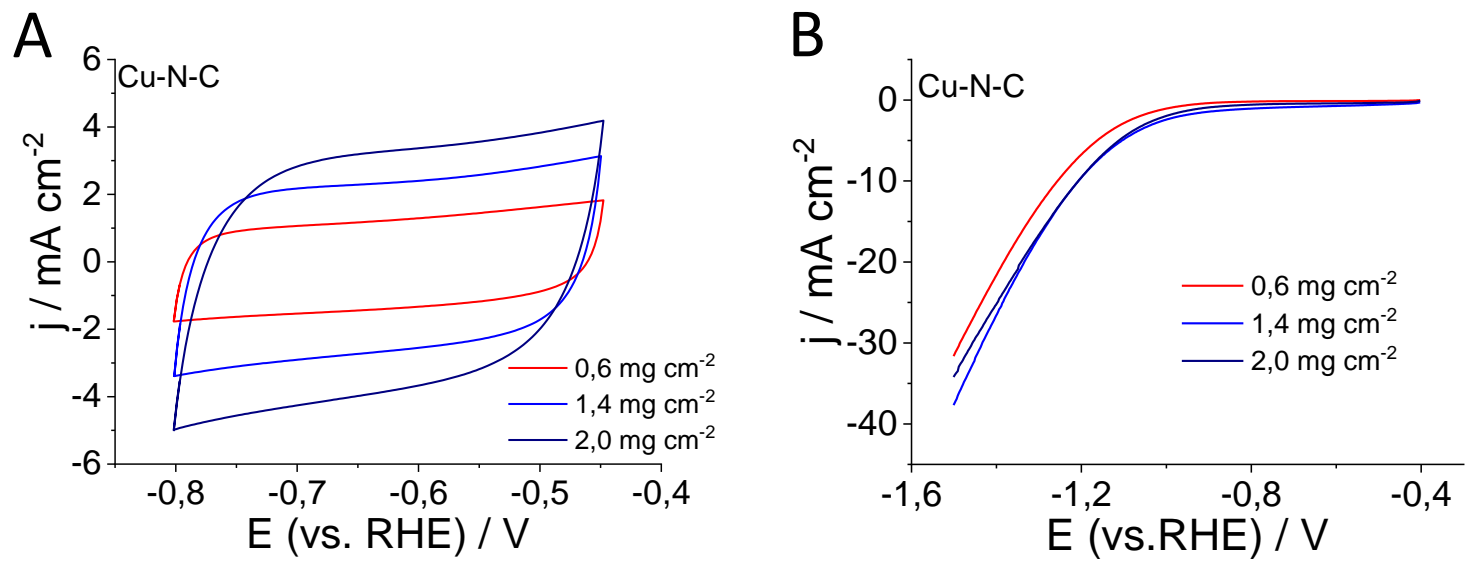

56. ábra: (A): A Cu-N-C elektródok ciklikus voltammogramjai három különböző borítottság esetén $\mathrm{CO}_{2}$ dal telített 0,5 M KHCO3-oldatban, $50 \mathrm{mV} \mathrm{s}^{-1}$ pásztázási sebességgel. (B): A három különböző borítottságú $\mathrm{Cu}-\mathrm{N}-\mathrm{C}$ elektród lineáris voltammogramjai $\mathrm{CO}_{2}$-dal telített $0,5 \mathrm{M} \mathrm{KHCO}_{3}$-oldatban $5 \mathrm{mV} \mathrm{s}^{-1}$ pásztázási sebességgel.

Az azonos borítottságú $\mathrm{M}-\mathrm{N}-\mathrm{C}$ elektródok elektrokémiailag aktív felületét a ciklikus voltammogramokból meghatározott kettősréteg kapacitás értékekből becsültük (57. ábra). Összehasonlításként egy sima felületü üvegszén elektródot használtunk, melynek feltételeztük, hogy elektrokémiai felülete egységnyi. A 9. táblázatban látható, hogy a fématomok jelenléte hatással volt az aktív felületre is. Mind a négy fémtartalmú minta esetén nagyobb volt a valós elektrokémiai felület a fémmentes mintához képest. Továbbá az Mo- $\mathrm{N}-\mathrm{C}$ és a $\mathrm{Ce}-\mathrm{N}-\mathrm{C}$ felülete több, mint másfélszer nagyobb volt a $\mathrm{Pr}-\mathrm{N}-\mathrm{C}$ és a $\mathrm{Cu}-\mathrm{N}-\mathrm{C}$ felületénél. Ez szintén alátámasztja a korábbi megfigyelésünket, miszerint a pirolízis körülményeit a fém prekurzor minősége befolyásolja. 


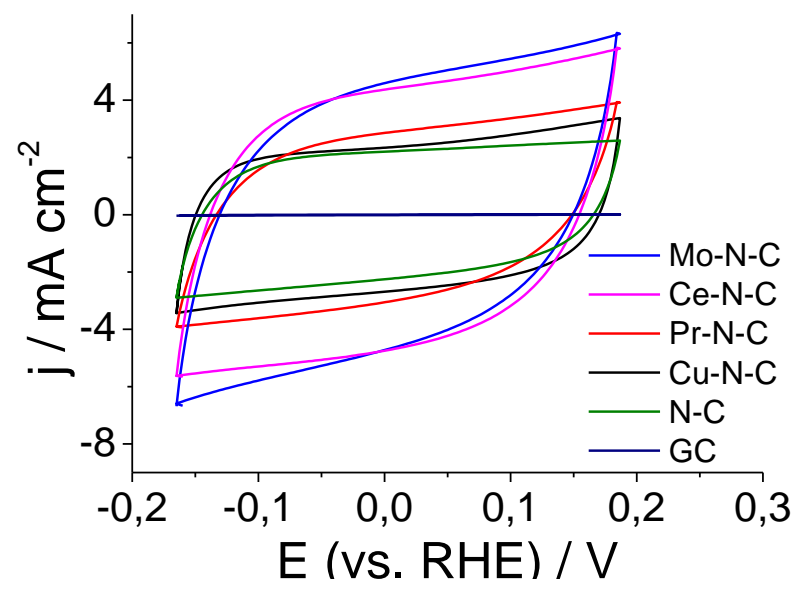

57. ábra: A vizsgált (M)-N-C katalizátorok és egy üvegszén elektród ciklikus voltammogramjai $\mathrm{CO}_{2}$-dal telített $0,5 \mathrm{M} \mathrm{KHCO}_{3}$-oldatban $50 \mathrm{mV} \mathrm{s}^{-1}$ pásztázási sebességgel. Az $(\mathrm{M})-\mathrm{N}-\mathrm{C}$ elektródok borítottsága 1,5 $\mathrm{mg} \mathrm{cm}^{-2}$ volt. A ciklikus voltammogramokból meghatározott kettősréteg-kapacitás értékekből becsültük az elektródok elektrokémiailag aktív felületét.

9. táblázat: Az (M)-N-C elektródok (1,5 mg cm$~^{-2}$ borítottság) elektrokémiailag aktív felületei $1 \mathrm{~cm}^{2}$ geomteriai felületre vonatkoztatva.

\begin{tabular}{|cc}
\hline Katalizátor & $\begin{array}{c}\text { Elektrokémiailag aktív felület } \\
\left(\mathbf{c m}^{\mathbf{2}} \mathbf{1} \mathbf{~ c m}^{\mathbf{2}} \text { geometriai felület }\right)\end{array}$ \\
\hline Mo-N-C & 302 \\
Ce-N-C & 291 \\
Pr-N-C & 190 \\
\hline Cu-N-C & 170 \\
N-C & 145 \\
\hline
\end{tabular}

\subsubsection{Szén-dioxid redukciós aktivitás}

Az $\mathrm{M}-\mathrm{N}-\mathrm{C}$ katalizátorok $\mathrm{CO}_{2}$ redukcióban és hidrogénfejlesztésben mutatott elektrokatalitikus aktivitásának gyors feltérképezése érdekében lineáris voltammogramokat vettünk fel $\mathrm{CO}_{2}$-dal telített $0,5 \mathrm{M} \mathrm{KHCO}_{3}$ oldatban (58. A ábra). $\mathrm{A}$ Pr-N-C és az $\mathrm{N}-\mathrm{C}$ elektródok viselkedése gyakorlatilag azonos volt mind a Faraday-áram indulásának potenciálja, mind pedig az elért áramsürüségek tekintetében. A $\mathrm{Ce}-\mathrm{N}-\mathrm{C}$ elektród ehhez képest kis áramtöbbletet mutatott a $-0,7 \mathrm{~V}$-nál negatívabb potenciálokon. A Mo- és Cu-tartalmú minta esetén azonban szembetünő eltérést láttunk: a $\mathrm{CO}_{2}$ redukcióhoz és a hidrogénfejlesztéshez köthető áram mintegy $300 \mathrm{mV}$-tal pozitívabb potenciálon indult és drasztikusan nagyobb volt a fémmentes $\mathrm{N}-\mathrm{C}$ katalizátorhoz képest (kb. háromszoros áramnövekmény $-0,9 \mathrm{~V}$-on). 
Fontos megjegyezni azonban, hogy nem láttunk egyértelmü összefüggést az elektrokémiai felületek és a redukciós áramok nagysága között ( $\mathrm{pl}$. $\mathrm{Cu}-\mathrm{N}-\mathrm{C})$. Ez arra utal, hogy az eltérő redukciós aktivitás nem csupán az elektrokémiai felületek különbözőségéből adódik, hanem valószínübb, hogy ez az egyes minták közötti kémiai különbségek eredménye. További összehasonlításként felvettük egy sima üvegszén elektród és egy rézlemez lineáris voltammogramját is, melyeket az 58. B ábrán mutatok be, összehasonlítva a $\mathrm{Cu}-\mathrm{N}-\mathrm{C}$ voltammogramjával. $\mathrm{A} \mathrm{Cu}-\mathrm{N}-\mathrm{C}$ esetén jelentősen nagyobb áramokat mértünk mindkét kontroll elektródhoz képest, továbbá a katalitikus áram indulása is a kevésbé negatív potenciálok felé tolódott (kb. $300 \mathrm{mV}$ különbség a rézlemezhez képest). Ez a tapasztalat arra utal, hogy az áramnövekmény nem csupán az $\mathrm{M}-\mathrm{N}-\mathrm{C}$ katalizátorok tömbi fémekhez képest megnövekedett felületéhez köthető, hanem ennek valóban a katalitikus centrumok eltérő kémiai minősége az oka.

A

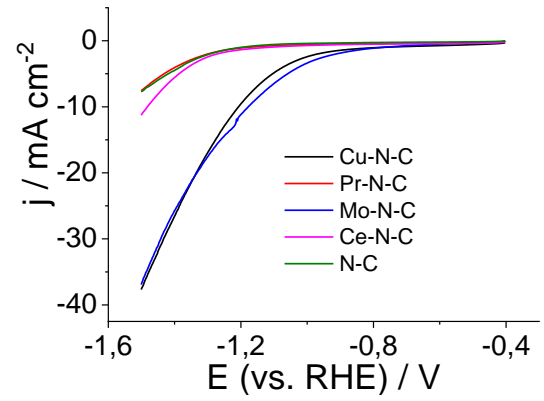

B

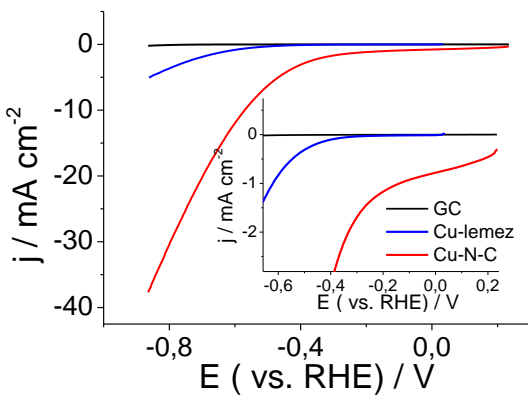

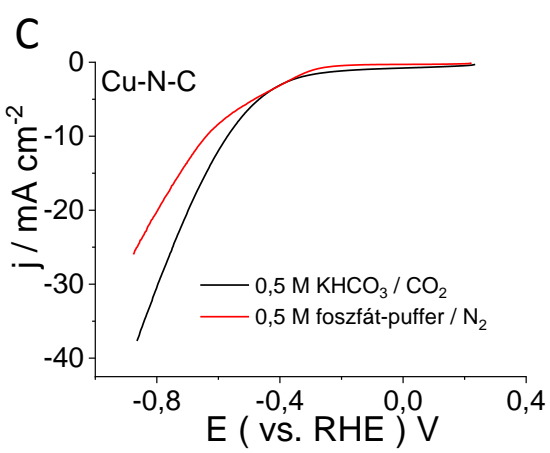

58. ábra: (A): A vizsgált (M)-N-C elektródok lineáris voltammogramjai $\mathrm{CO}_{2}$-dal telített $0,5 \mathrm{M} \mathrm{KHCO}_{3}$ oldatban $5 \mathrm{mV} \mathrm{s}$ s $^{-1}$ pásztázási sebességgel. (B): A $\mathrm{Cu}-\mathrm{N}-\mathrm{C}$ elektród, egy rézlemez és egy üres üvegszén elektród lineáris voltammogramja $\mathrm{CO}_{2}$-dal telített $0,5 \mathrm{M} \mathrm{KHCO}_{3}$ oldatban $5 \mathrm{mV} \mathrm{s}$ pásztázási sebességgel.

(C): A Cu-N-C lineáris voltammogramjai $\mathrm{CO}_{2}$ jelenlétében $\left(0,5 \mathrm{M} \mathrm{KHCO}_{3} / \mathrm{CO}_{2}\right)$ és annak hiányában $\left(0,5 \mathrm{M}\right.$ foszfát-puffer $\left./ \mathrm{N}_{2}\right) 5 \mathrm{mV} \mathrm{s}^{-1}$ pásztázási sebességgel.

Mivel $\mathrm{CO}_{2}$ jelenlétében a voltammetriás áramsürüség a $\mathrm{CO}_{2}$ redukciójához és a hidrogénfejlesztéshez köthető áramsürüségek szuperpozíciója, kontroll kísérleteket végeztünk $\mathrm{CO}_{2}$ hiányában, hogy különbséget tegyünk a két folyamat között és kiválasszuk azt a potenciáltartományt, ahol érdemes a termékek analízisét elvégezni. Az 58. C ábrán a $\mathrm{Cu}-\mathrm{N}-\mathrm{C}$

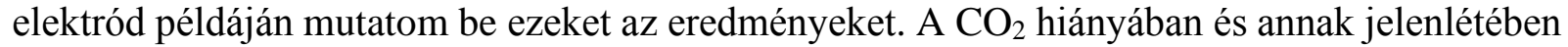
felvett voltammogramok alakja nagyon hasonló volt, azonban $\mathrm{CO}_{2}$ jelenlétében mintegy 100 $\mathrm{mV}$-tal kevésbé negatív volt a redukciós áram indulásának potenciálja. Továbbá a -0,45 V-nál negatívabb potenciálokon áramnövekmény volt megfigyelhető. Ez a $\mathrm{CO}_{2}$ redukció jelenlétére 
utalt az említett potenciálnál negatívabb értékeken, ezért a folyamat szelektivitását ezen a tartományon vizsgáltuk.

Mindegyik katalizátor esetén három potenciálon végeztünk elektrolízist (59. ábra), miközben a keletkező termékeket GC (gázfázis) és GC-MS (folyadékfázis) segítségével vizsgáltuk. A redukció során a gázfázisban $\mathrm{CO}$ és $\mathrm{H}_{2}$ fejlődését figyeltük meg, folyadékfázisú termékek képződését nem tapasztaltuk. A különböző minták között a stacionárius redukciós áramsürüségek sorrendje ugyanaz volt, mint amit a lineáris voltammetriás mérések során tapasztaltunk. Szembetűnő azonban a redukciós áram instabilitása a $\mathrm{Cu}-\mathrm{N}-\mathrm{C}$ esetén. Bár kezdetben nagy áramokat mutatott, negatívabb potenciálokon $(-0,66$ és $-0,86 \mathrm{~V})$ ez igen gyorsan lecsökkent. Ez nagy valószínűséggel a nagyobb méretű nanorészecskék redukció közbeni részleges kioldódásának a következménye. Ezzel szemben a $\mathrm{Ce}-\mathrm{N}-\mathrm{C}$ és a $\mathrm{Mo}-\mathrm{N}-\mathrm{C}$ mintáknál a stacionárius állapot elérését követően (kb. 180 s) gyakorlatilag nem volt áramcsökkenés, ami az egyes fémek stabilitásra gyakorolt hatását is jól mutatja.

A

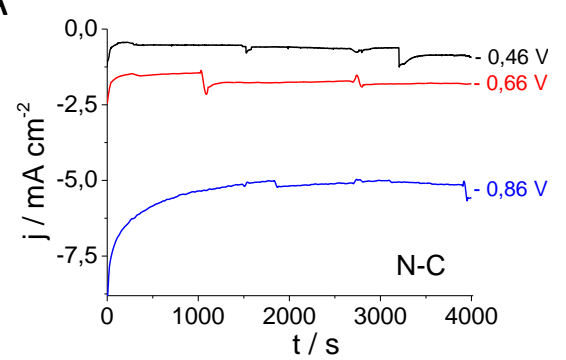

D

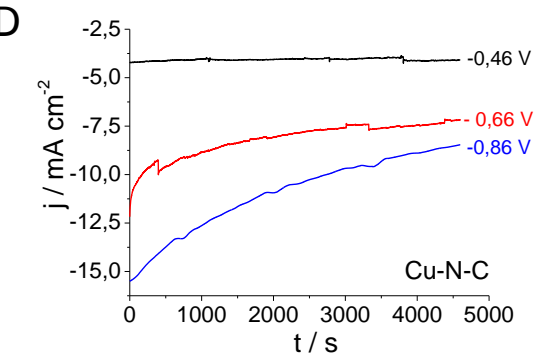

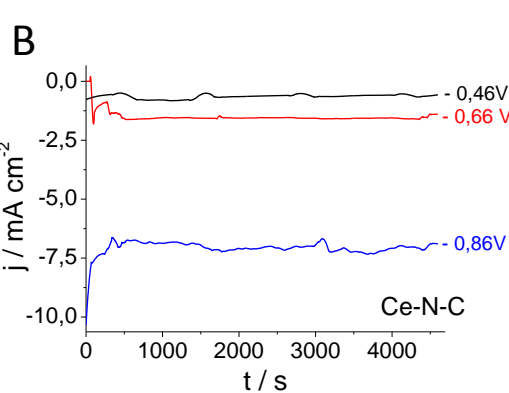

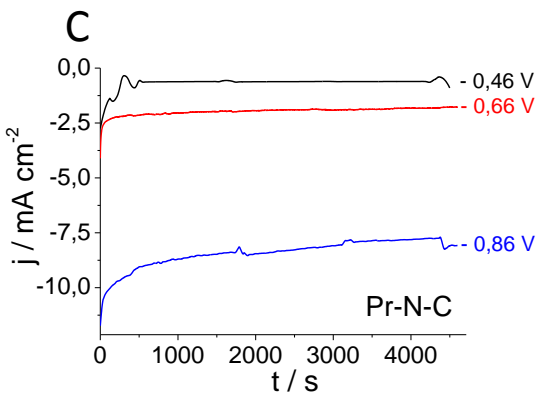

$\mathrm{E}$

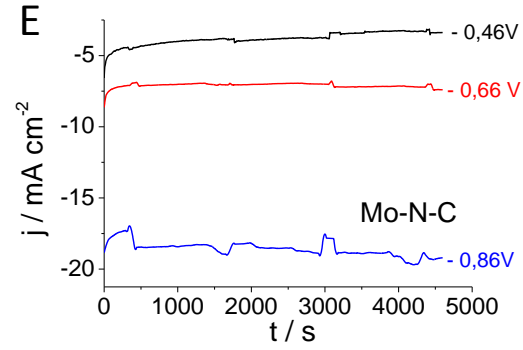

59. ábra: Az (M)-N-C elektródok kronoamperometriás görbéi $\mathrm{CO}_{2}$-dal telített $0,5 \mathrm{M}$ KHCO3-oldatban három különböző potenciálon $(-0,46 \mathrm{~V} ;-0,66 \mathrm{~V} ;-0,86 \mathrm{~V}$ vs. RHE).

A $\mathrm{CO} / \mathrm{H}_{2}$ mólaránya a fémmentes $\mathrm{N}-\mathrm{C}$ minta esetén volt a legnagyobb. Kevésbé negatív potenciálokon (-0,46 V-on) ez körülbelül 50-50 \% volt, ami a túlfeszültség növelésével $(-0,86 \mathrm{~V}) 30 \% \mathrm{CO}-70 \% \mathrm{H}_{2}$ értékre változott. A potenciosztatikus elektrolízist ennél az elektródnál ${ }^{13} \mathrm{C}$ jelzett $\mathrm{NaHCO}_{3}$ elektrolit alkalmazásával is megismételtük (60. ábra), miközben a keletkező $\mathrm{CO}$ izotópösszetételét GC-MS segítségével vizsgáltuk $\left(\mathrm{a}_{2} \mathrm{CO}_{2}\right.$ gáz ebben 
az esetben nem volt izotópjelzett). Ennek során a ${ }^{13} \mathrm{CO}$ és a ${ }^{12} \mathrm{CO}$ molekulaionjaihoz tartozó $\mathrm{m} / \mathrm{z}=28$ és $\mathrm{m} / \mathrm{z}=29$ ionokat követtük. Míg a nem jelzett $\mathrm{NaH}^{12} \mathrm{CO}_{3}$ elektrolit alkalmazásakor az összes keletkező CO mindössze $1 \%$-ka volt ${ }^{13} \mathrm{CO}$, ami megfelel a ${ }^{13} \mathrm{C}$ természetes gyakoriságának, jelzett $\mathrm{NaH}^{13} \mathrm{CO}_{3}$ használatakor ez $55 \%$ volt. Ez az érték megközelíti a ${ }^{13} \mathrm{C}$ bemérési arányát a cellában $(60 \%)$. A $\left[{ }^{13} \mathrm{CO}\right] /\left[{ }^{12} \mathrm{CO}\right]$ koncentrációarány továbbá az elektrolízis ideje alatt közel állandó volt mind a jelzett mind pedig a nem jelzett esetben is (59. C és D ábrák). Ezek a kísérletek igazolták, hogy az $\mathrm{N}-\mathrm{C}$ elektródon képződő $\mathrm{CO}$ valóban a $\mathrm{CO}_{2}$ redukciójából származott.

A

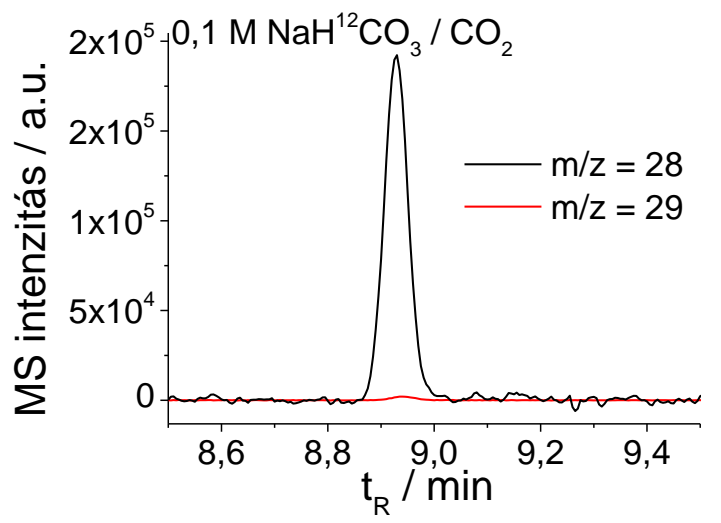

C

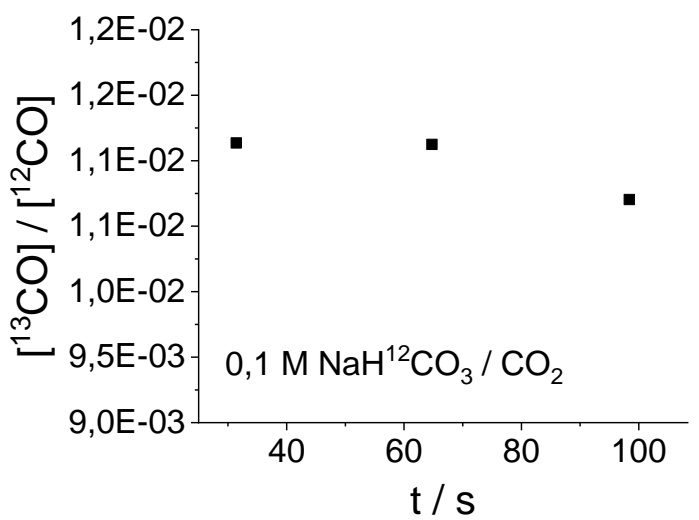

B

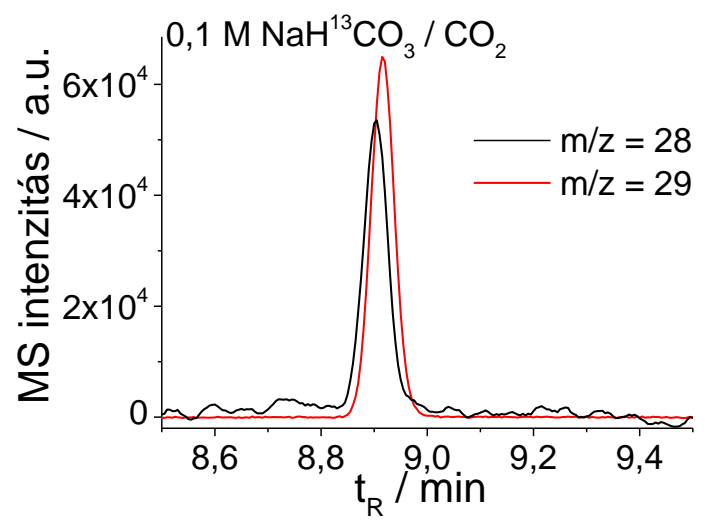

D

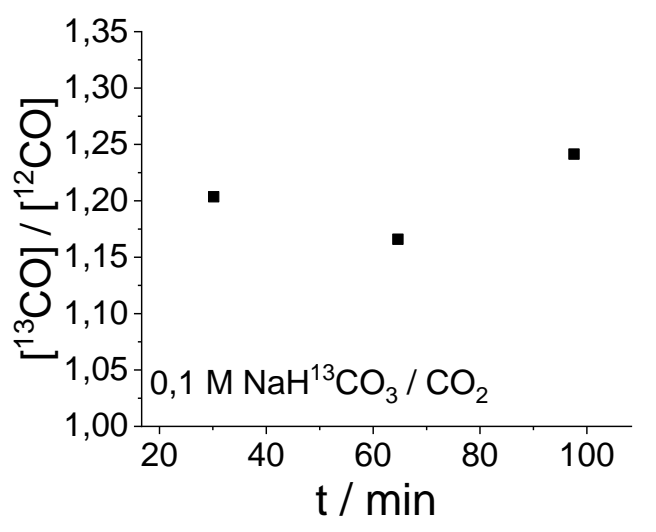

60. ábra: (A,B): Az N-C elektródon képződő CO GC-MS jele szelektív ionkövetés $(\mathrm{m} / \mathrm{z}=28$ és $\mathrm{m} / \mathrm{z}=29)$ módban, amennyiben nem izotópjelzett $\mathrm{NaH}^{12} \mathrm{CO}_{3}$ (A), és amennyiben izotópjelzett (B) $\mathrm{NaH}^{13} \mathrm{CO}_{3}$ elektrolit alkalmazásával végeztük a redukciót. $(\mathrm{C}, \mathrm{D})$ : A képződő ${ }^{13} \mathrm{CO}$ és ${ }^{12} \mathrm{CO}$, amennyiben nem izotópjelzett $\mathrm{NaH}^{12} \mathrm{CO}_{3}(\mathrm{C})$ és amennyiben izotópjelzett (D) $\mathrm{NaH}^{13} \mathrm{CO}_{3}$ elektrolitot használtunk.

A Ce- és a Mo-tartalmú katalizátorokon, melyek a legnagyobb áramsürüségeket mutatták, mindössze nyomnyi mennyiségü $(<1 \%)$ CO fejlödött, az áthaladt töltés nagy része a hidrogénfejlesztésre fordítódott. A $\mathrm{Pr}-\mathrm{N}-\mathrm{C}$ és a $\mathrm{Ce}-\mathrm{N}-\mathrm{C}$ mintákon ehhez képest a $\mathrm{CO}-$ szelektivitás kis mértékben nagyobb volt (6 és $14 \%-0,66 \mathrm{~V}$-on), azonban nem érte el a 
fémmentes katalizátor teljesítményét. $\mathrm{A} \mathrm{CO}_{2}$ redukcióra (CO-képződés) és a hidrogénfejlődésre vonatkozó parciális áramsürüségek az 61. ábrán láthatók az egyes minták esetén $-0,66 \mathrm{~V}$ potenciálon. Megfigyelhetö, hogy a fématomok beépítése a szén struktúrába növelte a teljes katalitikus aktivitást (61. A ábra), azonban ez a megnövekedett hidrogénfejlödés eredménye volt, különösen a Mo és a Cu centrumok esetén (61. B ábra). Ugyanakkor, mivel a fémmentes katalizátor mutatta a legnagyobb CO-szelektivitást, valószínű, hogy ezekben az anyagokban a $\mathrm{CO}_{2}$ redukcióért elsősorban a különböző nitrogénatomok a felelősek, míg a hidrogénfejlődés nagyobb mértékben a fémcentrumokhoz köthető. A fémcentrumok aktivitása viszont felülmúlja a nitrogén centrumok aktivitását.

A

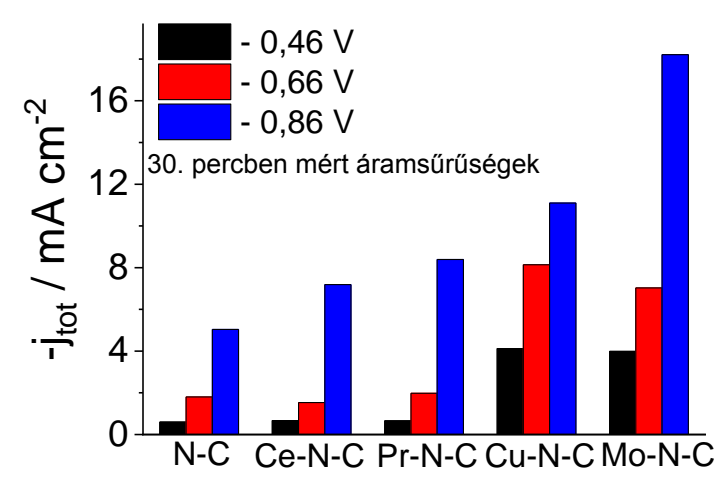

B

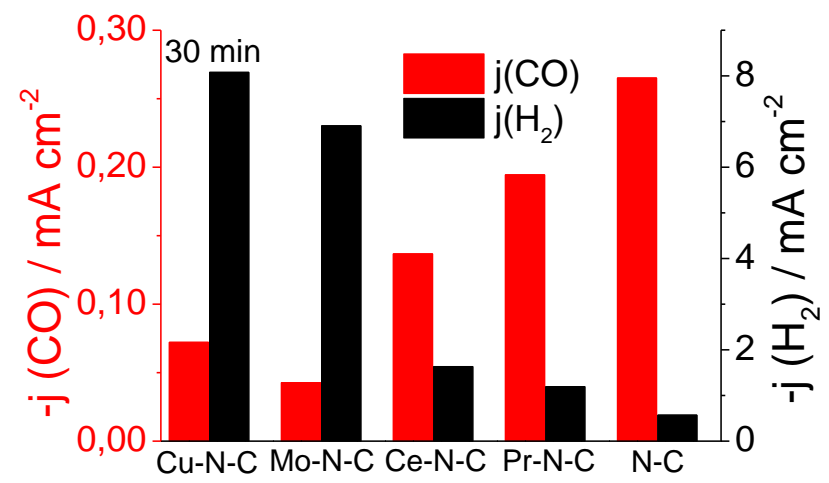

61. ábra: Az $\mathrm{M}-\mathrm{N}-\mathrm{C}$ elektródok katalitikus aktivitása a $\mathrm{CO}_{2}$ redukcióban és a hidrogénfejlesztésben. (A): Teljes redukciós áramsürüségek a potenciosztatikus elektrolízisek 30. percében három különböző elektródpotenciálon. (B): A $\mathrm{CO}_{2}$ redukció és a hidrogénfejlődés parciális áramsürüségei a potenciosztatikus elektrolízisek 30 . percében $-0,66 \mathrm{~V}$ potenciálon.

Próbáltunk összefüggést találni a katalizátorok kémiai összetétele és redukciós teljesítményük között. Ennek érdekében a $\mathrm{CO}_{2}$ redukciójára és a hidrogénfejlődésre vonatkozó parciális áramokat a különböző típusú $\mathrm{N}$-atomok koncentrációja és a fémtartalom függvényében ábrázoltuk (62. ábra). Egyértelmű összefüggést csupán két esetben tudtunk megállapítani: (i) a teljes fémtartalom növekedése a hidrogénfejlődésnek kedvezett, azonban ezzel párhuzamosan a $\mathrm{CO}_{2}$ redukció visszaszorult; (ii) a piridines nitrogén atomok mennyiségének növekedése szintén a hidrogénfejlődést segítette a $\mathrm{CO}_{2}$ redukcióval szemben.

A vizsgált katalizátorok redukciós teljesítményét meghatározó tényezők azonban összetettek, hiszen a különböző fém prekurzorok a szintézis során nemcsak a fémtartalmat, hanem magát az N-C váz fizikai-kémiai szerkezetét is módosították. Emiatt a kémiai összetétel, 
a morfológia vagy a grafitos szerkezet változásának hatását nehéz elkülöníteni, ehhez további szisztematikus vizsgálatok szükségesek. Összességében azonban elmondhatjuk, hogy a $\mathrm{Cu}-\mathrm{N}-\mathrm{C}$ és a Mo-N-C katalizátorok hidrogénfejlesztésben ígéretes alternatívái lehetnek a nemesfém katalizátoroknak.
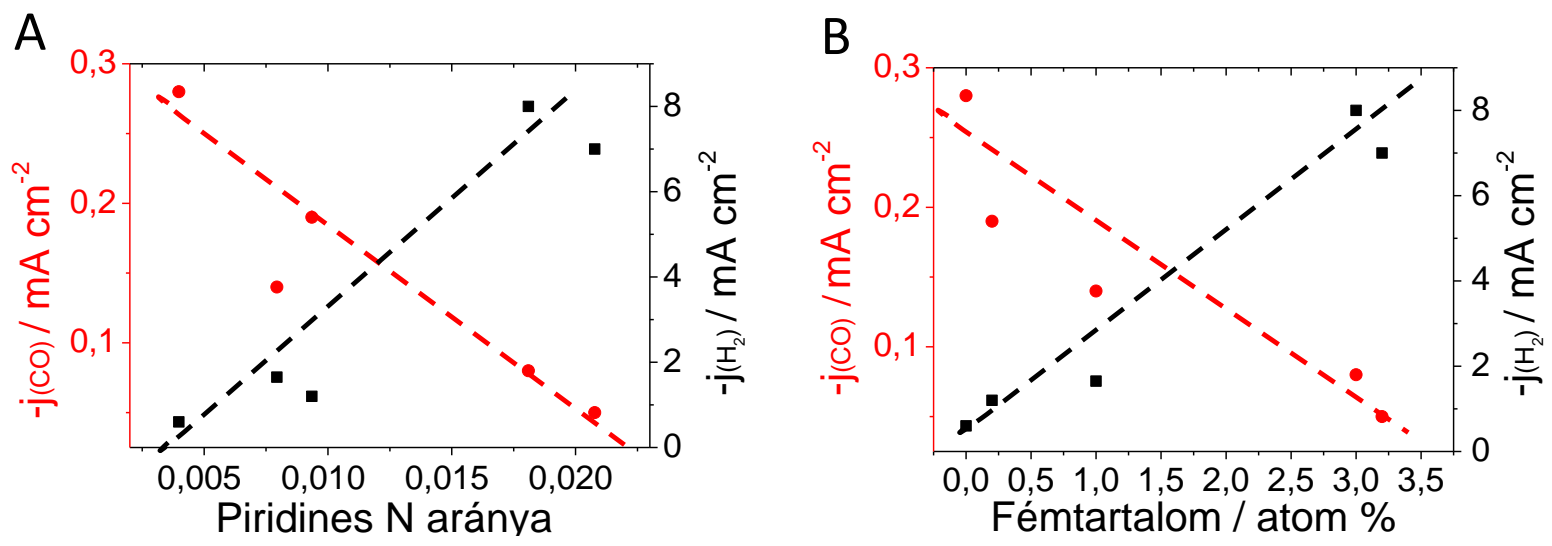

62. ábra: Összefüggés a redukciós aktivitás (parciális áramsűrűségek) és a katalizátorok felületi összetétele között. 


\section{6. Összefoglalás}

Doktori munkám során első lépésként a $\mathrm{CO}_{2}$ redukció mechanizmusát vizsgáltuk Nadalékolt szén elektródokon. Szelektív izotópjelzéses és pH-függő elektrolízis kísérletek segítségével megmutattuk, hogy a katalizátor felületén a közvetlenül reagáló részecske az oldott $\mathrm{CO}_{2}$ molekula, azonban az oldatban lévő hidrogén-karbonát ionoknak is kulcsszerepük van a folyamatban. Ezt követően az N-C katalizátorok különböző anyagi tulajdonságainak a $\mathrm{CO}_{2}$ redukcióra gyakorolt hatását tanulmányoztuk. Elsőként hajtottunk végre a pórusméret hatásának tanulmányozását célzó szisztematikus vizsgálatokat ezen katalizátorcsoporton. Megmutattuk, hogy csupán pórusok kialakításával egy $\mathrm{N}-\mathrm{C}$ katalizátorban drasztikusan növekedés érhető el a $\mathrm{CO}_{2}$ redukciós aktivitásban és szelektivitásban. A pórusszerkezet hatásának vizsgálatát követően az N-C katalizátorok felületi kémiai összetételének a redukciós aktivitásra gyakorolt hatását is tanulmányoztuk. Végül különbözö fémeket tartalmazó $\mathrm{M}-\mathrm{N}-\mathrm{C}$ katalizátorok $\mathrm{CO}_{2}$ redukcióban és hidrogénfejlesztésben mutatott aktivitását vizsgáltuk.

Doktori munkám legfontosabb eredményei a következö pontokban foglalhatók össze:

1. Megmutattuk, hogy a dinamikus egyensúlyi állapot elérése $\mathrm{CO}_{2, \mathrm{~g}}$ és a $\mathrm{HCO}_{3}{ }^{-}$,aq között nem pillanatszerü, esetünkben (adott cellageometria) mintegy két óra volt szükséges ehhez. Ez lehetőséget adott arra, hogy szelektív izotópjelzéses körülmények között a $\mathrm{CO}_{2}$ redukció során képződő CO izotópösszetételének időbeli követésével információt nyerjünk az elektródon közvetlenül reagáló részecske minőségéről.

2. A szelektív izotópjelzéses kísérletek során keletkező CO izotópösszetétele nemegyensúlyi körülmények között a hidrogén-karbonát ionokét tükrözte. Tekintettel arra, hogy ezt kétféle reakcióút is eredményezhette (közvetlen $\mathrm{HCO}_{3}{ }^{-}$,aq redukció vagy a $\mathrm{HCO}_{3}{ }^{-}$ionok által közvetített $\mathrm{CO}_{2}$,aq redukciója), pH-függő elektrolízis kísérletekkel egészítettük ki ezeket a vizsgálatokat. Különböző összetételü oldatokban végeztük a $\mathrm{CO}_{2}$ redukciót (és vizsgáltuk a szelektivitást), ahol a pH viszonyoknak megfelelöen dominánsan csak egyféle oldott részecske (vagy csak $\mathrm{CO}_{2}$,aq vagy csak $\mathrm{HCO}_{3}{ }^{-}$,aq $)$volt jelen. A kétféle vizsgálati módszer eredményeinek összevetésével megállapítottuk, hogy közvetlenül a $\mathrm{CO}_{2, \mathrm{aq}} \mathrm{t}$ redukáljuk a folyamatban, azonban csak akkor érhetünk el szelektív CO-képződést, ha az oldatban jelentős mennyiségü $\mathrm{HCO}_{3}{ }^{-}$,aq is jelen van. Ebben az esetben ugyanis ez utóbbi képes nagy effektív $\mathrm{CO}_{2}$ koncentrációt biztosítani az elektród közelében a fennálló $\mathrm{HCO}_{3}{ }^{-}$,qq $+\mathrm{H}^{+} \rightleftharpoons \mathrm{CO}_{2, \mathrm{aq}}+\mathrm{H}_{2} \mathrm{O}$ egyensúly által. 
3. Sikeresen állítottunk elő egy modellkatalizátor-családot, mely lehetőséget nyújtott arra, hogy szisztematikusan tanulmányozzuk az $\mathrm{N}-\mathrm{C}$ katalizátorok morfológiájának hatását a $\mathrm{CO}_{2}$ redukcióban. A különböző pórusméretű katalizátorokat vezető polimer prekurzorokból magas hőmérsékletü pirolízissel állítottuk elö, templátként különböző átmérőjű szilika nanorészecskéket alkalmazva. A szabályozott morfológia kialakításának sikerességét elektronmikroszkópiás és $\mathrm{N}_{2}$ adszorpciós / deszorpciós vizsgálatokkal igazoltuk: a katalizátorok átlagos pórusmérete jól tükrözte a templát részecskék méretét. Raman-spektroszkópiás, röntgendiffraktometriás és röntgen-fotoelektron spektroszkópiás mérésekkel megmutattuk, hogy a katalizátorok fizikai szerkezetükben és kémiai tulajdonságaikban elfogadható hibahatáron belül azonosak voltak. Ezáltal minden egyéb paraméter állandósága mellett tanulmányozhattuk a morfológia szerepét.

4. A $\mathrm{CO}_{2}$ redukciós aktivitás vizsgálata során jelentős eltéréseket tapasztaltunk a redukciós áramsürüségek és a szelektivitás tekintetében is a különböző pórusméretủ minták között. A COszelektivitásban mintegy háromszoros növekedést sikerült elérni csupán azáltal, hogy pórusokat alakítottunk ki az anyagban. A CO Faraday - hatásfoka és a redukciós áramsürüségek egyaránt az NC $<$ NC-90 < NC-13 < NC-27 sorrendben növekedtek. Fontos, hogy a redukciós áramokban mért különbségek nem csupán az eltérő elektrokémiai felületek eredménye volt, hiszen amennyiben a relatív érdesség értékekkel normáltuk a mért áramokat, ugyanezt a trendet figyeltük meg.

5. Azonosítottuk a katalizátorok morfológiájától függő, a redukciós aktivitást befolyásoló fő tényezőket. A pórusos minták szuperhidrofób jellege magyarázatként szolgált nagyobb COszelektivitásukra a kevésbé hidrofób nempórusos katalizátorral szemben, a pórusok vízzel való telítődésének megakadályozása által. A pórusméret csökkentésével továbbá a redukció során képződő gázbuborékok mérete és tartózkodási ideje is csökkent, ami további oka lehetett az $\mathrm{NC}-27$ és az $\mathrm{NC}-13$ nagyobb $\mathrm{CO}_{2}$ redukciós aktivitásának. Az NC-27 minta legnagyobb aktivitásának okát az ebben az esetben legerősebb $\mathrm{CO}_{2}$ adszorpcióval hoztuk összefüggésbe. Ezeken túl morfológiától függő geometriai tényezők (görbület mértéke, síkban és éleken lévő hibahelyek aránya) is szerepet játszhattak a különböző pórusméretű minták változó redukciós aktivitásában. 
6. Összefüggést találtunk a $\mathrm{CO}_{2}$ redukciós aktivitás, stabilitás és szelektivitás között a pórusos $\mathrm{N}-\mathrm{C}$ katalizátorok kapcsán. $\mathrm{A} \mathrm{CO}_{2}$ redukciós áram stabilitása - függetlenül a pórusmérettől- a CO fejlödés sebességével növekedett, azonban a szelektivitás növekedésével csökkent. Ezen érdekes megfigyelés okának felderítése azonban további vizsgálatokat igényel. Az NC-27 középtávú stabilitásvizsgálata során, bár a CO parciális áram fokozatosan csökkent, a pórusszerkezet nem változott lényegesen, vagyis a stabilitás csökkenéséért első sorban nem a morfológia változása volt a felelős.

7. A pórusméret hatásának vizsgálatát követően a felületi csoportok szerepét tanulmányoztuk a $\mathrm{CO}_{2}$ redukcióban. Ennek érdekében különböző vezető polimer prekurzorokból állítottunk elő $\mathrm{N}-\mathrm{C}$ katalizátorokat azonos $(27 \mathrm{~nm})$ pórusmérettel. Egy minta esetén utólagos kémiai kezeléseknek $\left(\mathrm{KOH}\right.$ és $\left.\mathrm{NH}_{3}\right)$ a redukciós aktivitásra gyakorolt hatását is tanulmányoztuk. A különböző prekurzorok eltérő felületi összetételt eredményeztek, mely befolyásolta a $\mathrm{CO}_{2}$ redukciós teljesítményt is. Nagyobb redukciós aktivitást és szelektivitást azoknál a mintáknál tapasztaltunk, melyeknél a kiindulási prekurzor többségében PoPD-t tartalmazott. Az ammóniás kezelés kismértékben növelte mind a redukciós áramokat, mind pedig a CO-szelektivitást, nagy valószínűséggel a hibahelyekben gazdagabb szerkezet miatt. Ezzel szemben a $\mathrm{KOH}-$ os kezelés gyakorlatilag megszüntette a $\mathrm{CO}_{2}$ redukció irányába mutatott aktivitást és szelektivitást is még a kétszeres felületnövekedés ellenére is. A különböző katalizátorok CO-képződésre vonatkozó parciális árama a szén struktúrába épült $\mathrm{N}$-atomok mennyiségével korrelált, kivéve az ammóniával kezelt minta esetén. Ez azt jelezte, hogy a funkciós csoportok jellegén és mennyiségén, valamint az elektromos tulajdonságokon túl más paraméterek is hatással vannak a $\mathrm{CO}_{2}$ redukciós tulajdonságokra.

8. A különböző prekurzorokból előállított $\mathrm{N}-\mathrm{C}$ minták katalitikus aktivitását a $\mathrm{CO}_{2}$ termikus hidrogénezési reakciójában is tanulmányoztuk. A termikus reakció során ugyanúgy CO és kisebb mértékben $\mathrm{CH}_{4}$ képződött, mint az elektrokémiai redukcióban és a különböző katalizátorok aktivitásának a sorrendje nagyon hasonló volt a két folyamatban. Ez azt jelzi, hogy függetlenül attól, hogy honnan származik a $\mathrm{CO}_{2}$ átalakításához szükséges energia, a két folyamat sebességmeghatározó elemi lépése nagyon hasonló. 
9. Végül négy különböző fémet tartalmazó ( $\mathrm{Mo}, \mathrm{Cu}, \mathrm{Pr}, \mathrm{Ce}) \mathrm{M}-\mathrm{N}-\mathrm{C}$ katalizátor $\mathrm{CO}_{2}$ redukcióban és $\mathrm{H}_{2}$ fejlesztésben mutatott aktivitását vizsgáltuk. Az XRD és az elektronmikroszkópos vizsgálatok alapján a szénvázban atomosan eloszlatott fémeken túl, mintánként eltérő mennyiségben, de kristályos fém fázisok is jelen voltak. A különböző fémek jelenléte a pirolízis során hatással volt az $\mathrm{N}-\mathrm{C}$ váz fizikai-kémiai szerkezetére is, ezáltal változott a katalizátorok kémiai összetétele (C-, N-tartalom és típus) és aktív felületük.

10. A fémmentes mintához képest a teljes katalitikus aktivitás csupán kis mértékben növekedett a $\operatorname{Pr}-\mathrm{N}-\mathrm{C}$ és a $\mathrm{Ce}-\mathrm{N}-\mathrm{C}$ esetén, míg a $\mathrm{Mo}-\mathrm{N}-\mathrm{C}$ és a $\mathrm{Cu}-\mathrm{N}-\mathrm{C}$ mintáknál jelentős aktivitásnövekedést tapasztaltunk. A fématomok beépítése a szén vázba a szelektivitást azonban minden esetben a hidrogénfejlődés irányába tolta el. A kémiai összetétel és a redukciós aktivitás között két összefüggést tudtunk felállítani: (i) a teljes fémtartalom és a (ii) piridines nitrogénatomok mennyiségének növekedése elősegítette a hidrogénfejlődést. 


\section{Summary}

The first step of my doctoral work was to study the $\mathrm{CO}_{2}$ reduction mechanism on $\mathrm{N}$ doped carbon $(\mathrm{N}-\mathrm{C})$ electrodes. By carrying out selective isotopic labeling and $\mathrm{pH}$-dependent electrolysis experiments, we demonstrated that the dissolved $\mathrm{CO}_{2}\left(\mathrm{CO}_{2, \mathrm{aq}}\right)$ is converted directly at the surface of these electrodes. The presence of bicarbonate ions in the electrolyte, however, is vital in achieving high CO-selectivity. As a next step, we studied the effect of different materials properties of $\mathrm{N}-\mathrm{C}$ catalysts on the $\mathrm{CO}_{2}$ reduction reaction. We sistematically investigated, for the first time, the role of porosity on the $\mathrm{CO}_{2}$ reduction performance of these materials. We showed that the catalytic activity and selectivity can drastically increase only by introducing pores in the carbon structure. We also studied the effect of surface chemical composition on the reduction performance of these metal-free catalysts. Finally, we studied the catalytic activity of metal-nitrogen doped carbon catalysts in the $\mathrm{CO}_{2}$ reduction and $\mathrm{H}_{2}$ evolution reactions.

The most important results of my doctoral work can be summarized in the following points:

1. We demonstrated that in a closed electrochemical cell with certain dimensions it takes around two hours to reach the dynamic equilibrium between the dissolved $\mathrm{HCO}_{3}{ }^{-}$,aq and the $\mathrm{CO}_{2, \mathrm{~g}}$. This fact allowed us to find out what is the actual reacting species in the $\mathrm{CO}_{2}$ reduction at the surface of these $\mathrm{N}-\mathrm{C}$ catalysts, by following the isotopic composition of the produced $\mathrm{CO}$ in time, under selective isotopic labeling conditions.

2. In the selective isotopic labeling experiments, when we were operating under nonequilibrium conditions, the isotopic composition of the produced $\mathrm{CO}$ mirrored that of bicarbonate ions. As this could be the result of two different reaction pathways (direct bicarbonate reduction or reduction of $\mathrm{CO}_{2 \text {,aq }}$ supplied through the bicarbonate equilibrium), we performed $\mathrm{pH}$-dependent electrolysis experiments as a control. We carried out the $\mathrm{CO}_{2}$ reduction employing electrolytes with different $\mathrm{pH}$ values in which only one carbonaceous species was dominantly present $\left(\mathrm{CO}_{2, \text { aq }}\right.$ or $\mathrm{HCO}_{3}{ }^{-}$aq $)$. Taken together the results of the isotopic labeling and the $\mathrm{pH}$-dependent experiments, we concluded that the reacting species at the surface on an $\mathrm{N}-\mathrm{C}$ electrode is most likely the $\mathrm{CO}_{2}$,aq. We can only achieve high $\mathrm{CO}$-selectivity, however, if bicarbonate ions are also present in the electrolyte, because they quickly supply $\mathrm{CO}_{2, \mathrm{aq}}$ near the electrode through the $\mathrm{HCO}_{3, \text { aq }}{ }^{-}+\mathrm{H}^{+} \rightleftharpoons \mathrm{CO}_{2, \mathrm{aq}}+\mathrm{H}_{2} \mathrm{O}$ equilibrium. 
3. We successfully synthesized a model catalyst system which allowed us to systematically study the effect of morphology on the $\mathrm{CO}_{2}$ reduction performance of $\mathrm{N}-\mathrm{C}$ catalysts. The catalysts with different pore sizes were synthesized by a sacrificial support method, starting from conducting polymer precursors. The controlled morphology of the obtained materials was verified by electron microscopic analysis and $\mathrm{N}_{2}$ adsorption / desorption measurements. Raman spectroscopic, XRD and XPS measurements revealed that the catalysts were very similar in their physical-chemical properties other than the porosity. This gave us a platform to study the effect of morphology in the $\mathrm{CO}_{2}$ reduction reaction, while keeping all other parameters unchanged.

4. We could see a massive alteration in the $\mathrm{CO}_{2}$ reduction activity and selectivity of the catalysts with varying pore sizes. The CO-selectivity increased by a factor of three only by introducing pores in the carbon structure. Both the $\mathrm{CO}$ Faradaic efficiencies and the reduction current densities increased in the order of $\mathrm{NC}<\mathrm{NC}-90<\mathrm{NC}-13<\mathrm{NC}-27$. The differences in the current densities were not the results of the varying electrochemical surface areas, as when we normalized the currents by the roughness factors, we observed the same general trend.

5. We identified the main factors dictating the catalytic performance of the electrodes with different porosity. The superhydrophobic nature of the porous samples was one reason for their increased $\mathrm{CO}_{2}$ reduction performance compared to the nonporous catalyst, because of the absence of water flooding. The size and residence time of the gas bubbles formed during electrolysis decreased with the decreasing pore size, resulting in enhanced $\mathrm{CO}_{2}$ transport. This could be a further reason for the better $\mathrm{CO}_{2}$ reduction activity of $\mathrm{NC}-13$ and $\mathrm{NC}-27$. The strongest $\mathrm{CO}_{2}$ adsorption in case of NC-27 explained its highest $\mathrm{CO}_{2}$ reduction performance among the studied catalysts. Finally, morphology-dependent geometric factors (degree of curvature, ratio of edge vs. in-plane defects) could also play a role in the varying reduction activity.

6. We found a correlation between the $\mathrm{CO}_{2}$ reduction activity, selectivity and stability regarding the studied $\mathrm{N}-\mathrm{C}$ catalysts. The stability of the $\mathrm{CO}_{2}$ reduction currents increased with the rate of $\mathrm{CO}$ production, but decreased with the increasing $\mathrm{CO}$-selectivity, independently of the pore size. The reason for this interesting observation, however, is still unknown. The CO partial currents of NC-27 continuously decreased during the medium-term (4h) stability test, however, the morphology remained stable during this timeframe. 
7. After studying the effect of porosity, we also investigated the role of different surface functional groups of the $\mathrm{N}-\mathrm{C}$ materials in the $\mathrm{CO}_{2}$ reduction reaction. We synthesized $\mathrm{N}-\mathrm{C}$ catalysts from different conducting polymer precursors with the same pore size $(27 \mathrm{~nm})$. For one sample we also studied the effect of different post-chemical treatments $\left(\mathrm{KOH}\right.$ and $\left.\mathrm{NH}_{3}\right)$ on the $\mathrm{CO}_{2}$ reduction performance. By employing different precursors, the surface chemical composition of the resulting $\mathrm{N}-\mathrm{C}$ materials changed, which resulted in varying reduction activity. Samples prepared from precursors containing higher amounts of PoPD showed higher reduction performance. The $\mathrm{NH}_{3}$-treatment slightly increased both the reduction activity and selectivity, most probably because of the formation of a more defect-rich structure. In contrast, the $\mathrm{KOH}$-treatment drastically decreased the $\mathrm{CO}_{2}$ reduction activity and selectivity, despite the two-fold increase in the specific surface area. The $\mathrm{CO}$ partial current densities increased with the total $\mathrm{N}$-contents, except for the $\mathrm{NH}_{3}$-treated sample This indicated, that besides the surface composition and the electric properties of the materials, there are other factors dictating the catalytic performance of these catalysts.

8 The catalytic activity of the $\mathrm{N}-\mathrm{C}$ materials synthesized from different precursors was also studied in the thermally activated hydrogenation of $\mathrm{CO}_{2}$. In this reaction $\mathrm{CO}$ and in a smaller amount $\mathrm{CH}_{4}$ were formed as reduction products, such as in the case of the electrochemical $\mathrm{CO}_{2}$ reduction. The trend in the activity of the different catalysts was also very similar in the two cases, indicating that rate-determining steps of the two processes are very similar, independently of the source of energy.

9. Finally, we studied four $\mathrm{M}-\mathrm{N}-\mathrm{C}$ catalysts in the electrochemical $\mathrm{CO}_{2}$ reduction and $\mathrm{H}_{2}$ evolution reactions. XRD and electronmicroscopic analysis revealed that besides the atomically dispersed metals, crsytalline metal phases were also present in the materials. The presence of different metals during the synthesis resulted in changes in chemical composition $(\mathrm{C}, \mathrm{N}$-content and type) and the surface area of the catalysts.

10. Compared to the metal-free sample, the catalytic activity only slightly increased in case of $\mathrm{Pr}-\mathrm{N}-\mathrm{C}$ and $\mathrm{Ce}-\mathrm{N}-\mathrm{C}$, while we could see a drastic activity-improvement for the $\mathrm{Mo}-\mathrm{N}-\mathrm{C}$ and $\mathrm{Cu}-\mathrm{N}-\mathrm{C}$ samples. This activity improvement was, however, the result of the increased $\mathrm{H}_{2}$ evolution in each case (and not the increased $\mathrm{CO}_{2}$ reduction). We identified a correlation 
between the $\mathrm{H}_{2}$ evolution activity and the metal- and pyridinic $\mathrm{N}$-contents of the catalyst samples. 


\section{Irodalomjegyzék}

(1) Hannah Ritchie; Max Roser. Energy production \& changing energy sources. https://ourworldindata.org/energy-production-and-changing-energy-sources (Megtekintve: 2019. 09. 19.).

(2) Monthly average Manua Loa $\mathrm{CO}_{2}$ https://www.esrl.noaa.gov/gmd/webdata/ccgg/trends/co2_trend_mlo.pdf (Megtekintve: 2019. 09. 09.).

(3) Fleischer, M.; Jeanty, P.; Wiesner-Fleischer, K.; Hinrichsen, O. Industrial approach for direct electrochemical $\mathrm{CO}_{2}$ reduction in aqueous electrolytes. In Zukünftige Kraftstoffe; Maus, W., Ed.; Springer Berlin Heidelberg, 2019, 224-250.

(4) Kibria, M. G.; Edwards, J. P.; Gabardo, C. M.; Dinh, C.-T.; Seifitokaldani, A.; Sinton, D.; Sargent, E. H. Electrochemical $\mathrm{CO}_{2}$ reduction into chemical feedstocks: from mechanistic electrocatalysis models to system design. Adv. Mater. 2019, 31, 1807166

(5) Kätelhön, A.; Meys, R.; Deutz, S.; Suh, S.; Bardow, A. Climate change mitigation potential of carbon capture and utilization in the chemical industry. Proc. Natl. Acad. Sci. 2019, 116, 11187

(6) De Luna, P.; Hahn, C.; Higgins, D.; Jaffer, S. A.; Jaramillo, T. F.; Sargent, E. H. What would it take for renewably powered electrosynthesis to displace petrochemical processes? Science, 2019, 364, eeav3506

(7) Bushuyev, O. S.; De Luna, P.; Dinh, C. T.; Tao, L.; Saur, G.; van de Lagemaat, J.; Kelley, S. O.; Sargent, E. H. What should we make with $\mathrm{CO}_{2}$ and how can we make it? Joule, 2018, 2, 825

(8) Zheng, T.; Jiang, K.; Wang, H. Recent advances in electrochemical $\mathrm{CO}_{2}$-to-CO conversion on heterogeneous catalysts. Adv. Mater. 2018, 30, 1802066

(9) Endrődi, B.; Bencsik, G.; Darvas, F.; Jones, R.; Rajeshwar, K.; Janáky, C. Continuousflow electroreduction of carbon dioxide. Prog. Energy Combust. Sci. 2017, 62, 133

(10) Daems, N.; Sheng, X.; Vankelecom, I. F. J.; Pescarmona, P. P. Metal-free doped carbon materials as electrocatalysts for the oxygen reduction reaction. J. Mater. Chem. A 2014, 2,4085

(11) Varela, A. S.; Ju, W.; Strasser, P. Molecular nitrogen-carbon catalysts, solid metal organic framework catalysts, and solid metal/nitrogen-doped carbon (MNC) catalysts for the Electrochemical $\mathrm{CO}_{2}$ reduction. Adv. Energy Mater. 2018, 8, 1703614

(12) Lai, J.; Nsabimana, A.; Luque, R.; Xu, G. 3D porous carbonaceous electrodes for electrocatalytic applications. Joule 2018, 2, 76

(13) Properties of atoms, chemicals and bonds. In Lange's handbook of chemistry; John A. Dean, Ed.; McGRAW-HILL, Inc., 1985, 4.41-4.53.

(14) Zhu, D. D.; Liu, J. L.; Qiao, S. Z. Recent advances in inorganic heterogeneous electrocatalysts for reduction of carbon dioxide. Adv. Mater. 2016, 28, 3423.

(15) Greenblatt, J. B.; Miller, D. J.; Ager, J. W.; Houle, F. A.; Sharp, I. D. The technical and energetic challenges of separating (photo)electrochemical carbon dioxide reduction 
products. Joule 2018, 2, 381.

(16) Ross, M. B.; Dinh, C. T.; Li, Y.; Kim, D.; De Luna, P.; Sargent, E. H.; Yang, P. Tunable $\mathrm{Cu}$ enrichment enables designer syngas electrosynthesis from $\mathrm{CO}_{2} . \mathrm{J}$. Am. Chem. Soc. 2017, 139, 9359.

(17) Cheng, Y.; Yang, S.; Jiang, S. P.; Wang, S. Supported single atoms as new class of catalysts for electrochemical reduction of carbon dioxide. Small Methods 2019, 1800440

(18) Verma, S.; Lu, S.; Kenis, P. J. A. Co-electrolysis of $\mathrm{CO}_{2}$ and glycerol as a pathway to carbon chemicals with improved technoeconomics due to low electricity consumption. Nat. Energy 2019, 4, 466.

(19) Pander III, J. E.; Ren, D.; Yeo, B. S. Practices for the collection and reporting of electrocatalytic performance and mechanistic information for the $\mathrm{CO}_{2}$ reduction reaction. Catal. Sci. Technol. 2017, 7, 5820.

(20) Bergmann, A.; Roldan Cuenya, B. Operando insights into nanoparticle transformations during catalysis. ACS Catal. 2019, 9, 10020.

(21) Jhong, H.-R. "Molly"; Ma, S.; Kenis, P. J. A. Electrochemical conversion of $\mathrm{CO}_{2}$ to useful chemicals: current status, remaining challenges, and future opportunities. Curr. Opin. Chem. Eng. 2013, 2, 191.

(22) Clark, E. L.; Resasco, J.; Landers, A.; Lin, J.; Chung, L.-T.; Walton, A.; Hahn, C.; Jaramillo, T. F.; Bell, A. T. Standards and protocols for data acquisition and reporting for studies of the electrochemical reduction of carbon dioxide. ACS Catal. 2018, 8 , 6560 .

(23) Zhu, W.; Michalsky, R.; Metin, Ö.; Lv, H.; Guo, S.; Wright, C. J.; Sun, X.; Peterson, A. A.; Sun, S. Monodisperse Au nanoparticles for selective electrocatalytic reduction of $\mathrm{CO}_{2}$ to CO. J. Am. Chem. Soc. 2013, 135, 16833.

(24) Chen, Y.; Li, C. W.; Kanan, M. W. Aqueous $\mathrm{CO}_{2}$ reduction at very low overpotential on oxide-derived Au nanoparticles. J. Am. Chem. Soc. 2012, 134, 19969.

(25) Mistry, H.; Choi, Y.-W.; Bagger, A.; Scholten, F.; Bonifacio, C. S.; Sinev, I.; Divins, N. J.; Zegkinoglou, I.; Jeon, H. S.; Kisslinger, K.; et al. Enhanced carbon dioxide electroreduction to carbon monoxide over defect-rich plasma-activated silver catalysts. Angew. Chemie 2017, 129, 11552.

(26) Ismail, A. M.; Samu, G. F.; Balog, Á.; Csapó, E.; Janáky, C. Composition-dependent electrocatalytic behavior of $\mathrm{Au}-\mathrm{Sn}$ bimetallic nanoparticles in carbon dioxide reduction. ACS Energy Lett. 2019, 4, 48.

(27) Song, Y.; Chen, W.; Zhao, C.; Li, S.; Wei, W.; Sun, Y. Metal-free nitrogen-doped mesoporous carbon for electroreduction of $\mathrm{CO}_{2}$ to ethanol. Angew. Chemie Int. Ed. 2017, 56, 10840.

(28) Pan, Y.; Lin, R.; Chen, Y.; Liu, S.; Zhu, W.; Cao, X.; Chen, W.; Wu, K.; Cheong, W.C.; Wang, Y.; et al. Design of single-atom $\mathrm{Co}-\mathrm{N}_{5}$ catalytic site: A robust electrocatalyst for $\mathrm{CO}_{2}$ reduction with nearly $100 \% \mathrm{CO}$ selectivity and remarkable stability. J. Am. Chem. Soc. 2018, 140, 4218. 
(29) Sun, X.; Kang, X.; Zhu, Q.; Ma, J.; Yang, G.; Liu, Z.; Han, B. Very highly efficient reduction of $\mathrm{CO}_{2}$ to $\mathrm{CH}_{4}$ using metal-free $\mathrm{N}$-doped carbon electrodes. Chem. Sci. 2016, 7, 2883.

(30) Leonard, N.; Ju, W.; Sinev, I.; Steinberg, J.; Luo, F.; Varela, A. S.; Roldan Cuenya, B.; Strasser, P. The chemical identity, state and structure of catalytically active centers during the electrochemical $\mathrm{CO}_{2}$ reduction on porous $\mathrm{Fe}$-nitrogen-carbon $(\mathrm{Fe}-\mathrm{N}-\mathrm{C})$ materials. Chem. Sci. 2018, 9, 5064.

(31) Zhang, S.; Kang, P.; Ubnoske, S.; Brennaman, M. K.; Song, N.; House, R. L.; Glass, T.; Meyer, T. J. Polyethylenimine-enhanced electrocatalytic reduction of $\mathrm{CO}_{2}$ to formate at nitrogen-doped carbon nanomaterials. 2014, 136, 7845.

(32) Hori, Y.; Kikuchi, K.; Suzuki, S. Production of $\mathrm{CO}$ and $\mathrm{CH}_{4}$ in electrochemical reduction of $\mathrm{CO}_{2}$ at metal electrodes in aqueous hydrogencarbonate solution. Chem. Lett. 1985, 14, 1695.

(33) Li, Q.; Fu, J.; Zhu, W.; Chen, Z.; Shen, B.; Wu, L.; Xi, Z.; Wang, T.; Lu, G.; Zhu, J.; et al. Tuning Sn-catalysis for electrochemical reduction of $\mathrm{CO} 2$ to $\mathrm{CO}$ via the core/shell $\mathrm{Cu} / \mathrm{SnO} 2$ structure. J. Am. Chem. Soc. 2017, 139, 4290.

(34) Hori, Y.; Wakebe, H.; Tsukamoto, T.; Koga, O. Electrocatalytic process of CO selectivity in electrochemical reduction of $\mathrm{CO}_{2}$ at metal electrodes in aqueous media. Electrochim. Acta 1994, 39, 1833.

(35) Wu, J.; Sharifi, T.; Gao, Y.; Zhang, T.; Ajayan, P. M. Emerging carbon-based heterogeneous catalysts for electrochemical reduction of carbon dioxide into valueadded chemicals. Adv. Mater. 2019, 31, 1804257.

(36) Li, Y.; Sun, Q. Recent advances in breaking scaling relations for effective electrochemical conversion of $\mathrm{CO}_{2}$. Adv. Energy Mater. 2016, 6, 1600463.

(37) Chen, Z.; Higgins, D.; Yu, A.; Zhang, L.; Zhang, J. A review on non-precious metal electrocatalysts for PEM fuel cells. Energy Environ. Sci. 2011, 4, 3167.

(38) Workman, M. J.; Dzara, M.; Ngo, C.; Pylypenko, S.; Serov, A.; McKinney, S.; Gordon, J.; Atanassov, P.; Artyushkova, K. Platinum group metal-free electrocatalysts: Effects of synthesis on structure and performance in proton-exchange membrane fuel cell cathodes. J. Power Sources 2017, 348, 30.

(39) Guo, D.; Shibuya, R.; Akiba, C.; Saji, S.; Kondo, T.; Nakamura, J. Active sites of nitrogen-doped carbon materials for oxygen reduction reaction clarified using model catalysts. Science 2016, 351,361.

(40) Lai, J.; Li, S.; Wu, F.; Saqib, M.; Luque, R.; Xu, G. Unprecedented metal-free 3D porous carbonaceous electrodes for full water splitting. Energy Environ. Sci. 2016, 9 , 1210

(41) Paul, R.; Zhu, L.; Chen, H.; Qu, J.; Dai, L. Recent advances in carbon-based metal-free electrocatalysts. Adv. Mater. 2019, 31, 1806403.

(42) Artyushkova, K.; Serov, A.; Rojas-Carbonell, S.; Atanassov, P. Chemistry of multitudinous active sites for oxygen reduction reaction in transition metal-nitrogencarbon electrocatalysts. J. Phys. Chem. C 2015, 119, 25917. 
(43) Kiuchi, H.; Shibuya, R.; Kondo, T.; Nakamura, J.; Niwa, H.; Miyawaki, J.; Kawai, M.; Oshima, M.; Harada, Y. Lewis Basicity of nitrogen-doped graphite observed by $\mathrm{CO}_{2}$ chemisorption. Nanoscale Res. Lett. 2016, 11, 127.

(44) Liu, T.; Ali, S.; Lian, Z.; Li, B.; Su, D. S. CO 2 electoreduction reaction on heteroatomdoped carbon cathode materials. J. Mater. Chem. A 2017, 5, 21596.

(45) Liu, S.; Yang, H.; Huang, X.; Liu, L.; Cai, W.; Gao, J.; Li, X.; Zhang, T.; Huang, Y.; Liu, B. Identifying active sites of nitrogen-doped carbon materials for the $\mathrm{CO}_{2}$ reduction reaction. Adv. Funct. Mater. 2018, 28, 1800499.

(46) Li, H.; Xiao, N.; Hao, M.; Song, X.; Wang, Y.; Ji, Y.; Liu, C.; Li, C.; Guo, Z.; Zhang, F.; et al. Efficient $\mathrm{CO}_{2}$ electroreduction over pyridinic-N active sites highly exposed on wrinkled porous carbon nanosheets. Chem. Eng. J. 2018, 351, 613.

(47) Sharma, P. P.; Wu, J.; Yadav, R. M.; Liu, M.; Wright, C. J.; Tiwary, C. S.; Yakobson, B. I.; Lou, J.; Ajayan, P. M.; Zhou, X.-D. Nitrogen-doped carbon nanotube arrays for high-efficiency electrochemical reduction of $\mathrm{CO}_{2}$ : on the understanding of defects, defect density, and selectivity. Angew. Chemie 2015, 54, 13701.

(48) Wu, J.; Liu, M.; Sharma, P. P.; Yadav, R. M.; Ma, L.; Yang, Y.; Zou, X.; Zhou, X. D.; Vajtai, R.; Yakobson, B. I.; et al. Incorporation of nitrogen defects for efficient reduction of $\mathrm{CO}_{2}$ via two-electron pathway on three-dimensional graphene foam. Nano Lett. 2016, 16, 466.

(49) Li, W.; Seredych, M.; Rodríguez-Castellón, E.; Bandosz, T. J. Metal-free nanoporous carbon as a catalyst for electrochemical reduction of $\mathrm{CO}_{2}$ to $\mathrm{CO}$ and $\mathrm{CH}_{4}$. ChemSusChem 2016, 9, 606.

(50) Liu, Y.; Chen, S.; Quan, X.; Yu, H. Efficient electrochemical reduction of carbon dioxide to acetate on nitrogen-doped nanodiamond. J. Am. Chem. Soc. 2015, 137, 11631.

(51) Lum, Y.; Kwon, Y.; Lobaccaro, P.; Chen, L.; Clark, E. L.; Bell, A. T.; Ager, J. W. Trace levels of copper in carbon materials show significant electrochemical $\mathrm{CO}_{2}$ reduction activity. ACS Catal. 2016, 6, 202.

(52) Kumar, B.; Asadi, M.; Pisasale, D.; Sinha-Ray, S.; Rosen, B. a; Haasch, R.; Abiade, J.; Yarin, A. L.; Salehi-Khojin, A. renewable and metal-free carbon nanofibre catalysts for carbon dioxide reduction. Nat. Commun. 2013, 4, 2819.

(53) Jhong, H.-R. "Molly"; Brushett, F. R.; Kenis, P. J. A. The effects of catalyst layer deposition methodology on electrode performance. Adv. Energy Mater. 2013, 3, 589.

(54) Wu, J.; Yadav, R. M.; Liu, M.; Sharma, P. P.; Tiwary, C. S.; Ma, L.; Zou, X.; Zhou, X.D.; Yakobson, B. I.; Lou, J.; et al. Achieving highly efficient, selective, and stable $\mathrm{CO}_{2}$ reduction on nitrogen-doped carbon nanotubes. ACS Nano 2015, 9, 5364.

(55) Daiyan, R.; Tan, X.; Chen, R.; Saputera, W. H.; Tahini, H. A.; Lovell, E.; Ng, Y. H.; Smith, S. C.; Dai, L.; Lu, X.; et al. Electroreduction of $\mathrm{CO}_{2}$ to $\mathrm{CO}$ on a mesoporous carbon catalyst with progressively removed nitrogen moieties. ACS Energy Lett. 2018, 3, 2292.

(56) Pan, F.; Liang, A.; Duan, Y.; Liu, Q.; Zhang, J.; Li, Y. Self-growth-templating 
synthesis of 3D N,P,co-doped mesoporous carbon frameworks for efficient bifunctional oxygen and carbon dioxide electroreduction. J. Mater. Chem. A 2017, 5, 13104..

(57) Wang, H.; Chen, Y.; Hou, X.; Ma, C.; Tan, T. Nitrogen-doped graphenes as efficient electrocatalysts for the selective reduction of carbon dioxide to formate in aqueous solution. Green Chem. 2016, 18, 3250.

(58) Jhong, H.-R. M.; Tornow, C. E.; Smid, B.; Gewirth, A. A.; Lyth, S. M.; Kenis, P. J. A. A nitrogen-doped carbon catalyst for electrochemical $\mathrm{CO}_{2}$ conversion to $\mathrm{CO}$ with high selectivity and current density. ChemSusChem 2017, 9, 1.

(59) Wang, H.; Jia, J.; Song, P.; Wang, Q.; Li, D.; Min, S.; Qian, C.; Wang, L.; Li, Y. F.; $\mathrm{Ma}, \mathrm{C}$; ; et al. Efficient electrocatalytic reduction of $\mathrm{CO}_{2}$ by nitrogen-doped nanoporous carbon/carbon nanotube membranes: A step towards the electrochemical $\mathrm{CO}_{2}$ refinery. Angew. Chemie Int. Ed. 2017, 56, 7847.

(60) Pan, F.; Li, B.; Xiang, X.; Wang, G.; Li, Y. Efficient $\mathrm{CO}_{2}$ electroreduction by highly dense and active pyridinic nitrogen on holey carbon layers with fluorine engineering. ACS Catal. 2019, 9, 2124.

(61) Pan, F.; Li, B.; Deng, W.; Du, Z.; Gang, Y.; Wang, G.; Li, Y. Promoting electrocatalytic $\mathrm{CO}_{2}$ reduction on nitrogen-doped carbon with sulfur addition. Appl. Catal. B Environ. 2019, 252, 240.

(62) Wu, J.; Ma, S.; Sun, J.; Gold, J. I.; Tiwary, C.; Kim, B.; Zhu, L.; Chopra, N.; Odeh, I. N.; Vajtai, R.; et al. A metal-free electrocatalyst for carbon dioxide reduction to multicarbon hydrocarbons and oxygenates. Nat. Commun. 2016, 7, 13869.

(63) Zou, X.; Liu, M.; Wu, J.; Ajayan, P. M.; Li, J.; Liu, B.; Yakobson, B. I. How nitrogendoped graphene quantum dots catalyze electroreduction of $\mathrm{CO}_{2}$ to hydrocarbons and Oxygenates. ACS Catal. 2017, 7 (9), 6245.

(64) Jouny, M.; Luc, W.; Jiao, F. High-rate electroreduction of carbon monoxide to multicarbon products. Nat. Catal. 2018, 1, 748.

(65) Dunwell, M.; Lu, Q.; Heyes, J. M.; Rosen, J.; Chen, J. G.; Yan, Y.; Jiao, F.; Xu, B. The central role of bicarbonate in the electrochemical reduction of carbon dioxide on gold. J. Am. Chem. Soc. 2017, 139, 3774.

(66) Ma, C.; Hou, P.; Wang, X.; Wang, Z.; Li, W.; Kang, P. Carbon nanotubes with rich pyridinic nitrogen for gas phase CO2 electroreduction. Appl. Catal. B Environ. 2019, $250,347$.

(67) Cui, X.; Pan, Z.; Zhang, L.; Peng, H.; Zheng, G. Selective etching of nitrogen-doped carbon by steam for enhanced electrochemical $\mathrm{CO}_{2}$ reduction. Adv. Energy Mater. 2017, 7, 1701456.

(68) Duan, X.; Xu, J.; Wei, Z.; Ma, J.; Guo, S.; Wang, S.; Liu, H.; Dou, S. Metal-free carbon materials for $\mathrm{CO}_{2}$ electrochemical reduction. Adv. Mater. 2017, 29, 1701784.

(69) Ju, W.; Bagger, A.; Hao, G.-P.; Varela, A. S.; Sinev, I.; Bon, V.; Roldan Cuenya, B.; Kaskel, S.; Rossmeisl, J.; Strasser, P. Understanding activity and selectivity of ,metalnitrogen-doped carbon catalysts for electrochemical reduction of $\mathrm{CO}_{2}$. Nat. Commun. 2017, 8, 944. 
(70) Li, X.; Bi, W.; Chen, M.; Sun, Y.; Ju, H.; Yan, W.; Zhu, J.; Wu, X.; Chu, W.; Wu, C.; et al. Exclusive $\mathrm{Ni}-\mathrm{N}_{4}$ sites realize near-unity $\mathrm{CO}$ selectivity for electrochemical $\mathrm{CO}_{2}$ reduction. J. Am. Chem. Soc. 2017, 139, 14889.

(71) Pan, F.; Zhang, H.; Liu, K.; Cullen, D.; More, K.; Wang, M.; Feng, Z.; Wang, G.; Wu, $\mathrm{G} . ; \mathrm{Li}, \mathrm{Y}$. Unveiling active sites of $\mathrm{CO}_{2}$ reduction on nitrogen-coordinated and atomically dispersed iron and cobalt catalysts. ACS Catal. 2018, 8, 3116.

(72) Gu, J.; Hsu, C.-S.; Bai, L.; Chen, H. M.; Hu, X. Atomically dispersed Fe ${ }^{3+}$ sites catalyze efficient $\mathrm{CO}_{2}$ electroreduction to CO. Science 2019, 364, 1091.

(73) Möller, T.; Ju, W.; Bagger, A.; Wang, X.; Luo, F.; Ngo Thanh, T.; Varela, A. S.; Rossmeisl, J.; Strasser, P. Efficient $\mathrm{CO}_{2}$ to $\mathrm{CO}$ electrolysis on solid Ni-N-C catalysts at industrial current densities. Energy Environ. Sci. 2019, 12, 640.

(74) Varela, A. S.; Ranjbar Sahraie, N.; Steinberg, J.; Ju, W.; Oh, H. S.; Strasser, P. Metaldoped nitrogenated carbon as an efficient catalyst for direct $\mathrm{CO}_{2}$ electroreduction to $\mathrm{CO}$ and hydrocarbons. Angew. Chemie - Int. Ed. 2015, 54, 10758.

(75) Huan, T. N.; Ranjbar, N.; Rousse, G.; Sougrati, M.; Zitolo, A.; Mougel, V.; Jaouen, F.; Fontecave, M. Electrochemical reduction of $\mathrm{CO}_{2}$ catalyzed by Fe-N-C materials: a structure - selectivity study. ACS Catal. 2017, 7, 1520.

(76) Pan, F.; Deng, W.; Justiniano, C.; Li, Y. Identification of champion transition metal centers in metal and nitrogen-codoped carbon catalysts for $\mathrm{CO}_{2}$ reduction. Appl. Catal. B Environ. 2018, 226, 463.

(77) Su, P.; Iwase, K.; Nakanishi, S.; Hashimoto, K.; Kamiya, K. Nickel-nitrogen-modified graphene: an efficient electrocatalyst for the reduction of carbon dioxide to carbon monoxide. Small 2016, 12, 6083.

(78) Hu, X.-M.; Hval, H. H.; Bjerglund, E. T.; Dalgaard, K. J.; Madsen, M. R.; Pohl, M.-M.; Welter, E.; Lamagni, P.; Buhl, K. B.; Bremholm, M.; et al. Selective $\mathrm{CO}_{2}$ reduction to $\mathrm{CO}$ in water using earth-abundant metal and nitrogen-doped carbon electrocatalysts. ACS Catal. 2018, 8, 6255.

(79) Ju, W.; Bagger, A.; Wang, X.; Tsai, Y.; Luo, F.; Möller, T.; Wang, H.; Rossmeisl, J.; Varela, A. S.; Strasser, P. Unraveling mechanistic reaction pathways of the electrochemical $\mathrm{CO}_{2}$ reduction on $\mathrm{Fe}-\mathrm{N}-\mathrm{C}$ single-site catalysts. ACS Energy Lett. 2019, 4, 1663.

(80) Reske, R.; Mistry, H.; Behafarid, F.; Roldan Cuenya, B.; Strasser, P. Particle size effects in the catalytic electroreduction of $\mathrm{CO}_{2}$ on $\mathrm{Cu}$ nanoparticles. J. Am. Chem. Soc. 2014, 136, 6978.

(81) Gao, D.; Zhou, H.; Wang, J.; Miao, S.; Yang, F.; Wang, G.; Wang, J.; Bao, X. Sizedependent electrocatalytic reduction of $\mathrm{CO}_{2}$ over Pd nanoparticles. J. Am. Chem. Soc. 2015, 137 (13), 4288.

(82) Mistry, H.; Reske, R.; Zeng, Z.; Zhao, Z.-J.; Greeley, J.; Strasser, P.; Cuenya, B. R. Exceptional size-dependent activity enhancement in the electroreduction of $\mathrm{CO}_{2}$ over Au nanoparticles. J. Am. Chem. Soc. 2014, 136 (47), 16473.

(83) Arán-Ais, R. M.; Gao, D.; Roldan Cuenya, B. Structure- and electrolyte-sensitivity in 
$\mathrm{CO}_{2}$ electroreduction. Acc. Chem. Res. 2018, 51, 2906.

(84) Wang, Z.-L.; Li, C.; Yamauchi, Y. Nanostructured nonprecious metal catalysts for electrochemical reduction of carbon dioxide. Nano Today 2016, 11, 373.

(85) Dutta, A.; Rahaman, M.; Luedi, N. C.; Mohos, M.; Broekmann, P. Morphology matters: Tuning the product distribution of $\mathrm{CO}_{2}$ electroreduction on oxide-derived $\mathrm{Cu}$ foam catalysts. ACS Catal. 2016, 6, 3804.

(86) Sen, S.; Liu, D.; Palmore, G. T. R. Electrochemical reduction of $\mathrm{CO}_{2}$ at copper nanofoams. ACS Catal. 2014, 4, 3091..

(87) Liu, M.; Pang, Y.; Zhang, B.; De Luna, P.; Voznyy, O.; Xu, J.; Zheng, X.; Dinh, C. T.; Fan, F.; Cao, C.; et al. Enhanced electrocatalytic $\mathrm{CO}_{2}$ reduction via field-induced reagent concentration. Nature 2016, 537, 382.

(88) Chai, G.-L.; Guo, Z.-X. Highly effective sites and selectivity of nitrogen-doped graphene/CNT catalysts for $\mathrm{CO}_{2}$ electrochemical reduction. Chem. Sci. 2016, 7, 1268.

(89) Dutta, D.; Wood, B. C.; Bhide, S. Y.; Ayappa, K. G.; Narasimhan, S. Enhanced gas adsorption on graphitic substrates via defects and local curvature: A density functional theory study. J. Phys. Chem. C 2014, 118, 7741.

(90) Burdyny, T.; Graham, P. J.; Pang, Y.; Dinh, C.-T.; Liu, M.; Sargent, E. H.; Sinton, D. Nanomorphology-enhanced gas-evolution intensifies $\mathrm{CO}_{2}$ reduction electrochemistry. ACS Sustain. Chem. Eng. 2017, 5, 4031.

(91) Hall, A. S.; Yoon, Y.; Wuttig, A.; Surendranath, Y. Mesostructure-induced selectivity in $\mathrm{CO}_{2}$ reduction catalysis. J. Am. Chem. Soc. 2015, 137, 14834.

(92) Wang, X.; Varela, A. S.; Bergmann, A.; Kühl, S.; Strasser, P. Catalyst particle density controls hydrocarbon product selectivity in $\mathrm{CO}_{2}$ electroreduction on $\mathrm{CuO}_{\mathrm{x}}$. ChemSusChem 2017, 10, 4642.

(93) Mistry, H.; Behafarid, F.; Reske, R.; Varela, A. S.; Strasser, P.; Roldan Cuenya, B. Tuning catalytic selectivity at the mesoscale via interparticle interactions. ACS Catal. 2016, 6, 1075.

(94) Grosse, P.; Gao, D.; Scholten, F.; Sinev, I.; Mistry, H.; Roldan Cuenya, B. Dynamic changes in the structure, chemical state and catalytic selectivity of $\mathrm{Cu}$ nanocubes during $\mathrm{CO}_{2}$ electroreduction: Size and support effects. Angew. Chemie 2018, 130, 6300.

(95) Wei, W.; Liang, H.; Parvez, K.; Zhuang, X.; Feng, X.; Müllen, K. Nitrogen-doped carbon nanosheets with size-defined mesopores as highly efficient metal-free catalyst for the oxygen reduction reaction. Angew. Chemie Int. Ed. 2014, 53, 1570.

(96) Liang, J.; Zheng, Y.; Chen, J.; Liu, J.; Hulicova-Jurcakova, D.; Jaroniec, M.; Qiao, S. Z. Facile oxygen reduction on a three-dimensionally ordered macroporous graphitic $\mathrm{C}_{3} \mathrm{~N}_{4} /$ carbon composite electrocatalyst. Angew. Chemie Int. Ed. 2012, 51, 3892.

(97) Wang, G.; Sun, Y.; Li, D.; Liang, H.-W.; Dong, R.; Feng, X.; Müllen, K. Controlled synthesis of N-Doped carbon nanospheres with tailored mesopores through selfassembly of colloidal silica. Angew. Chemie Int. Ed. 2015, 54, 15191.

(98) To, J. W. F.; Chen, Z.; Yao, H.; He, J.; Kim, K.; Chou, H.-H.; Pan, L.; Wilcox, J.; Cui, 
Y.; Bao, Z. Ultrahigh surface area three-dimensional porous graphitic carbon from conjugated polymeric molecular framework. ACS Cent. Sci. 2015, 1, 68.

(99) Liang, H.-W.; Zhuang, X.; Brüller, S.; Feng, X.; Müllen, K. Hierarchically porous carbons with optimized nitrogen doping as highly active electrocatalysts for oxygen reduction. Nat. Commun. 2014, 5, 4973.

(100) Yamamoto, T.; Tryk, D. A.; Hashimoto, K.; Fujishima, A.; Okawa, M. Electrochemical reduction of $\mathrm{CO}_{2}$ in the micropores of activated carbon fibers. J. Electrochem. Soc. 2000, 147, 3393.

(101) Yang, H.; Wu, Y.; Lin, Q.; Fan, L.; Chai, X.; Zhang, Q.; Liu, J.; He, C.; Lin, Z. Composition tailoring via $\mathrm{N} \& \mathrm{~S}$ co-doping and structure tuning by constructing hierarchical pores enable metal-free catalysts for high-performance electrochemical reduction of CO2. Angew. Chemie Int. Ed. 2018, 130, 15702.

(102) Verma, S.; Lu, X.; Ma, S.; Masel, R. I.; Kenis, P. J. A. The effect of electrolyte composition on the electroreduction of $\mathrm{CO}_{2}$ to $\mathrm{CO}$ on $\mathrm{Ag}$ based gas diffusion electrodes. Phys. Chem. Chem. Phys. 2016, 18, 7075.

(103) Varela, A. S.; Kroschel, M.; Reier, T.; Strasser, P. Controlling the selectivity of $\mathrm{CO}_{2}$ electroreduction on copper: The effect of the electrolyte concentration and the importance of the local pH. Catal. Today 2016, 260, 8.

(104) Varela, A. S.; Ju, W.; Reier, T.; Strasser, P. Tuning the catalytic activity and selectivity of $\mathrm{Cu}$ for $\mathrm{CO}_{2}$ electroreduction in the presence of halides. ACS Catal. 2016, 6, 2136.

(105) Hashiba, H.; Weng, L.-C.; Chen, Y.; Sato, H. K.; Yotsuhashi, S.; Xiang, C.; Weber, A. Z. Effects of electrolyte buffer capacity on surface reactant species and the reaction rate of $\mathrm{CO}_{2}$ in electrochemical $\mathrm{CO}_{2}$ reduction. J. Phys. Chem. C 2018, 122 (7), 3719.

(106) Moura de Salles Pupo, M.; Kortlever, R. Electrolyte effects on the electrochemical reduction of $\mathrm{CO}_{2}$. ChemPhysChem 2019, 20, 2926.

(107) Burdyny, T.; Smith, W. A. CO2 reduction on gas-diffusion electrodes and why catalytic performance must be assessed at commercially-relevant conditions. Energy Environ. Sci. 2019, 12, 1442.

(108) Endrődi, B.; Kecsenovity, E.; Samu, A. A.; Darvas, F.; Jones, R. V; Török, V.; Danyi, A.; Janáky, C. Multi-layer electrolyzer stack converts carbon dioxide to gas products at high pressure with high efficiency. ACS Energy Lett. 2019, 4, 1770.

(109) Zhong, H.; Fujii, K.; Nakano, Y.; Jin, F. Effect of $\mathrm{CO}_{2}$ bubbling into aqueous solutions used for electrochemical reduction of $\mathrm{CO}_{2}$ for energy conversion and storage. J. Phys. Chem. C 2015, 119, 55.

(110) Innocent, B.; Pasquier, D.; Ropital, F.; Hahn, F.; Léger, J.-M.; Kokoh, K. B. FTIR spectroscopy study of the reduction of carbon dioxide on lead electrode in aqueous medium. Appl. Catal. B Environ. 2010, 94, 219.

(111) Kortlever, R.; Tan, K. H.; Kwon, Y.; Koper, M. T. M. Electrochemical carbon dioxide and bicarbonate reduction on copper in weakly alkaline media. J. Solid State Electrochem. 2013, 17, 1843.

(112) Zhong, H.; Fujii, K.; Nakano, Y. Electroactive species study in the electrochemical 
reduction of $\mathrm{CO}_{2}$ in $\mathrm{KHCO}_{3}$ solution at elevated temperature. J. Energy Chem. 2016, $25,517$.

(113) Hori, Y.; Suzuki, S. Electrolytic reduction of bicarbonate ion at a mercury electrode. $J$. Electrochem. Soc. 1983, 130, 2387.

(114) Min, X.; Kanan, M. W. Pd-Catalyzed electrohydrogenation of carbon dioxide to formate: high mass activity at low overpotential and identification of the deactivation pathway. J. Am. Chem. Soc. 2015, 137, 4701.

(115) Zhu, S.; Jiang, B.; Cai, W.-B.; Shao, M. Direct observation on reaction intermediates and the role of bicarbonate anions in $\mathrm{CO}_{2}$ electrochemical reduction reaction on $\mathrm{Cu}$ surfaces. J. Am. Chem. Soc. 2017, 139, 15664.

(116) Hori, Y. Electrochemical $\mathrm{CO}_{2}$ reduction on metal electrodes. In Modern Aspects of Electrochemistry; Vayenas, C. G., White, R. E., Gamboa-Aldeco, M. E., Eds.; Springer New York, 2008, 89-189.

(117) Ferrari, A. C.; Basko, D. M. Raman spectroscopy as a versatile tool for studying the properties of graphene. Nat. Nanotechnol. 2013, 8, 235.

(118) Li, Z. Q.; Lu, C. J.; Xia, Z. P.; Zhou, Y.; Luo, Z. X-ray diffraction patterns of graphite and turbostratic carbon. Carbon N. Y. 2007, 45, 1686.

(119) Kabir, S.; Artyushkova, K.; Serov, A.; Atanassov, P. Role of nitrogen moieties in Ndoped 3D-graphene nanosheets for oxygen electroreduction in acidic and alkaline media. ACS Appl. Mater. Interfaces 2018, 10, 11623.

(120) Physisorption of gases, with special reference to the evaluation of surface area and pore size distribution (IUPAC Technical Report) . Pure and Applied Chemistry . 2015, 87, 1051.

(121) Chibowski, E. Surface free energy of a solid from contact angle hysteresis. Adv. Colloid Interface Sci. 2003, 103, 149.

(122) Zhao, C.; Dai, X.; Yao, T.; Chen, W.; Wang, X.; Wang, J.; Yang, J.; Wei, S.; Wu, Y.; $\mathrm{Li}, \mathrm{Y}$. Ionic exchange of metal-organic frameworks to access single nickel sites for efficient electroreduction of $\mathrm{CO}_{2}$. J. Am. Chem. Soc. 2017, 139, 8078.

(123) Weng, L.-C.; Bell, A. T.; Weber, A. Z. Modeling gas-diffusion electrodes for $\mathrm{CO}_{2}$ reduction. Phys. Chem. Chem. Phys. 2018, 20, 16973.

(124) Wenzel, R. N. Surface roughness and contact angle. J. Phys. Colloid Chem. 1949, 53, 1466.

(125) Bico, J.; Thiele, U.; Quéré, D. Wetting of textured surfaces. Colloids Surfaces A Physicochem. Eng. Asp. 2002, 206, 41.

(126) Faber, M. S.; Dziedzic, R.; Lukowski, M. A.; Kaiser, N. S.; Ding, Q.; Jin, S. Highperformance electrocatalysis using metallic cobalt pyrite $\left(\mathrm{CoS}_{2}\right)$ micro- and nanostructures. J. Am. Chem. Soc. 2014, 136, 10053.

(127) Yadav, R. M.; Wu, J.; Kochandra, R.; Ma, L.; Tiwary, C. S.; Ge, L.; Ye, G.; Vajtai, R.; Lou, J.; Ajayan, P. M. Carbon nitrogen nanotubes as efficient bifunctional electrocatalysts for oxygen reduction and evolution reactions. ACS Appl. Mater. 
Interfaces 2015, 7, 11991.

(128) Sevilla, M.; Valle-Vigón, P.; Fuertes, A. B. N-doped polypyrrole-based porous carbons for $\mathrm{CO}_{2}$ capture. Adv. Funct. Mater. 2011, 21, 2781.

(129) Zhang, Z.; Zhou, J.; Xing, W.; Xue, Q.; Yan, Z.; Zhuo, S.; Qiao, S. Z. Critical role of small micropores in high $\mathrm{CO}_{2}$ uptake. Phys. Chem. Chem. Phys. 2013, 15, 2523.

(130) Mistry, H.; Varela, A. S.; Bonifacio, C. S.; Zegkinoglou, I.; Sinev, I.; Choi, Y.-W.; Kisslinger, K.; Stach, E. A.; Yang, J. C.; Strasser, P.; et al. Highly selective plasmaactivated copper catalysts for carbon dioxide reduction to ethylene. Nat. Commun. 2016, 7, 12123.

(131) Kas, R.; Kortlever, R.; Milbrat, A.; Koper, M. T. M.; Mul, G.; Baltrusaitis, J. Electrochemical $\mathrm{CO}_{2}$ reduction on $\mathrm{Cu}_{2} \mathrm{O}$-derived copper nanoparticles: controlling the catalytic selectivity of hydrocarbons. Phys. Chem. Chem. Phys. 2014, 16, 12194.

(132) Zheng, Y.; Vasileff, A.; Zhou, X.; Jiao, Y.; Jaroniec, M.; Qiao, S.-Z. Understanding the roadmap for electrochemical reduction of $\mathrm{CO}_{2}$ to multi-carbon oxygenates and hydrocarbons on copper-based catalysts. J. Am. Chem. Soc. 2019, 141, 7646.

(133) Shen, J.; Kortlever, R.; Kas, R.; Birdja, Y. Y.; Diaz-Morales, O.; Kwon, Y.; LedezmaYanez, I.; Schouten, K. J. P.; Mul, G.; Koper, M. T. M. Electrocatalytic reduction of carbon dioxide to carbon monoxide and methane at an immobilized cobalt protoporphyrin. Nat. Commun. 2015, 6, 8177.

(134) Wu, J.; Wen, C.; Zou, X.; Jimenez, J.; Sun, J.; Xia, Y.; Fonseca Rodrigues, M.-T.; Vinod, S.; Zhong, J.; Chopra, N.; et al. Carbon dioxide hydrogenation over a metal-free carbon-based catalyst. ACS Catal. 2017, 7, 4497.

(135) Vogt, C.; Monai, M.; Kramer, G. J.; Weckhuysen, B. M. The renaissance of the Sabatier reaction and its applications on Earth and in space. Nat. Catal. 2019, 2, 188.

(136) Janáky, C.; Hursan, D.; Endrődi, B.; Chanmanee, W.; Roy, D.; Liu, D.; De Tacconi, N. R.; Dennis, B. H.; Rajeshwar, K. Electro- and photoreduction of carbon dioxide: The twain shall meet at copper oxide / copper interfaces. ACS Energy Lett. 2016, 1, 332. 


\section{Köszönetnyilvánítás}

Ezúton szeretnék köszönetet mondani Dr. Tóth Ágotának, a Fizikai Kémiai és Anyagtudományi Tanszék vezetőjének, amiért lehetővé tette, hogy a tanszéken végezzem doktori munkámat.

Szeretném megköszönni témavezetőmnek, Dr. Janáky Csabának, hogy a kutatócsoportban töltött évek során mindvégig segített, támogatott, bármilyen kérdéssel fordultam hozzá. Szeretném továbbá megköszönni, hogy szakmai fejlődésemet szem előtt tartva lehetővé tette és támogatta nemzetközi konferenciákon való részvételeimet.

Köszönettel tartozom Dr. Janovák Lászlónak a peremszög mérésekben nyújtott segítségéért, valamint Dr. Sápi Andrásnak a heterogén katalitikus mérések elvégzéséért.

Köszönöm Dr. Plamen Atanassovnak (University of California, Irvine) és csoportjának az együttmüködés lehetőségét és az XPS mérések elvégzését.

Köszönöm a Fotoelektrokémiai Kutatócsoport jelenlegi és volt tagjainak, hogy mindenben szívesen segítettek és egy jó hangulatú, baráti munkakörnyezetet teremtettek. Külön köszönettel tartozom Samu Angelikának, Dr. Kormányos Attilának, Dr. Endrődi Balázsnak, Kecsenovity Egonnak és Balog Ádámnak, akik a mérések kivitelezésében is gyakran segítettek.

Továbbá köszönettel tartozom Prof. Visy Csabának, korábbi témavezetőmnek, hogy megszerettette velem a fizikai kémiát és az elektrokémiát, valamint mindvégig figyelemmel kísérte szakmai fejlődésemet.

Végül, de nem utolsó sorban köszönöm családomnak, akik mindvégig támogattak és nyugodt környezetet teremtettek az egyetemi és doktori tanulmányim során. 